

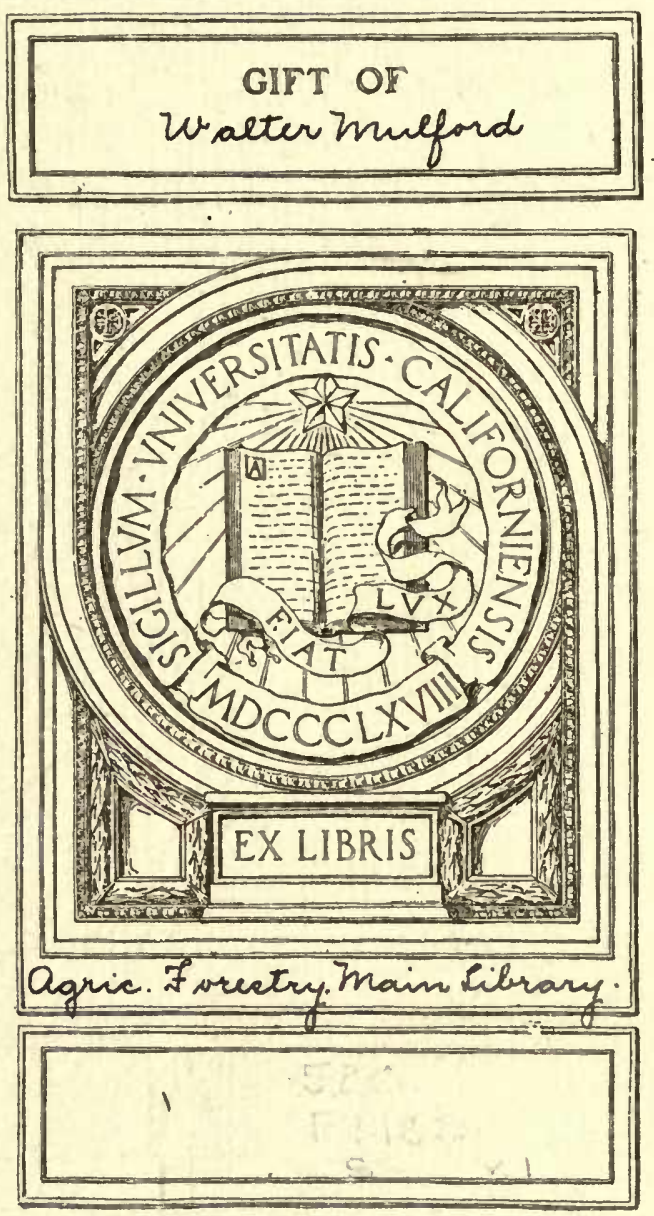




\section{Westbury Nurseries and the}

\section{Hicks Patent Tree-Mobers}

\section{ISAAC HICKS \& SON}

Westbury Station, Nassau County, Long Island, New York

TELEPHONE CONNECTION

Illustrated by photographs of trees which habe been moved, and of places most of which were planted with stock from the Westbury Nurseries

\section{CONTENTS}

Business terms ; Horticultural questions ; Scientific pruning and tree preservation; Skilled labor for planting.

Seaside Planting List . . . . . . . 5

Chart of Climatic Conditions of Long ISLAND ........... 6

\section{PART I.}

TREE-MOVING

I. The Moving of Large Deciduous TrEeS ............ I8

II. The Moving of Large Evergreen TREES .......... 20

\section{PART II.}

DESCRIPTIVE CATALOGUE OF ORNAMENTAL STOCK.

I. Deciduous Trees ........ . 2I Beech, Linden, Maple, Oak, etc.

II. Evergreen Trees . . . . . . . . 37 Coniferous, or Cone-bearing Evergreens; Fir, Pine, Retinospora, Spruce, Yew, etc.

III. Flowering Shrubs . . . . . . . 45 Azalea, Althea, Deutzia, Golden Bell, Japanese Maple, Magnolia, Privet, Snowball, Weigela, etc.
IV. Broad-Leaved Evergreen Shrubs 54 Boxwood, Holly, Laurel, Rhododendron, Myrtle, etc.

V. Vines, Creepers and Cover Plants . 58 A kebia, Clematis, Honeysuckle, Ivy, Trumpet Creeper, Wistaria.

VI. Roses .............6r

VII. Formal Garden Material. . . . . 64

Standard, or Bay-tree-form Privet, Boxwood, Sheared Pyramid and Dome Evergreens, Trained Evergreen and Privet Arches, Arbors, Terra-Cotta Vases, Tubs, etc.

VIII. Hardy Garden Flowers ......67 Anemone, Aster, Columbine, Hollyhock, Iris, Larkspur, Peony, Pink, Golden Glow, Yucca, etc.

IX. Hardy Flower Calendar .... . 76

\section{PART III.}

FRUIT TREES AND SMALL FRUITS

I. Apples, Pears, Plums, Cherry, Grapes, Currants, Gooseberry, Raspberry, Strawberry, Nuts, Asparagus, Rhubarb, Etc. . 78

INDEX . . . . . . . . . . . . . . . 88 


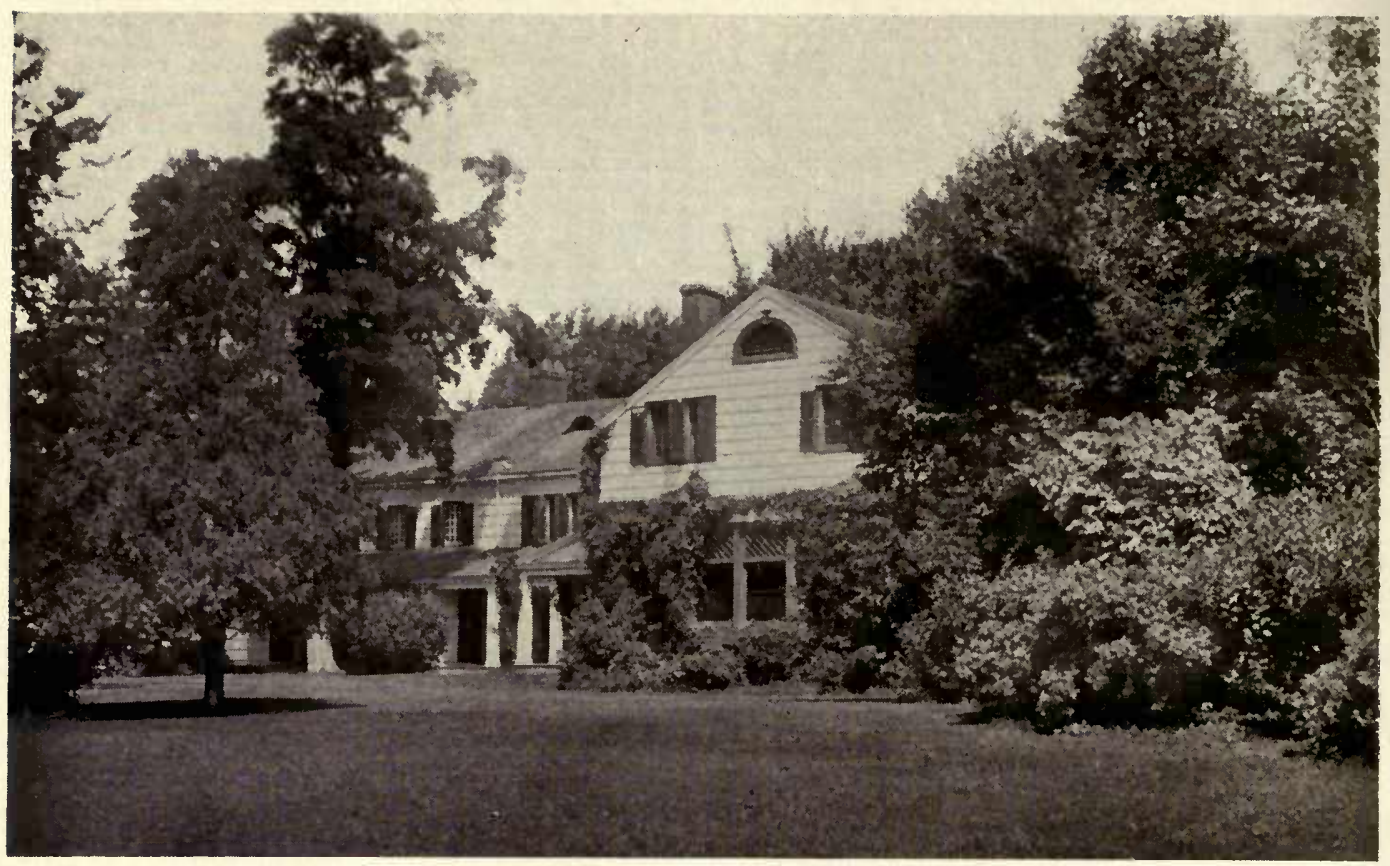

At the right, Linden and Maple, moved for Mr. Thomas Hitchcock, Jr. Incidentally a screen planting to the laundry paddock.

\section{PREFACE}

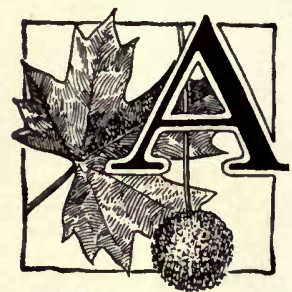

NEW and distinct type of nursery is shown in the Westbury Nurseries in the growing of large trees for immediate landscape results. No establishment in this country or Europe grows such a quantity or variety of large trees. The nursery was founded half a century ago, and many of the trees now available for moving were planted in the first decade of the business as specimens, and allowed to attain perfect development. More than twenty-five acres are devoted to the growing of extra-sized trees; the trees being placed 8 to 40 feet apart, permitting ample sunlight, air and soil. The object is not how cheap, but how perfect. A tree 4 inches in diameter, 20 feet high, may be in a close crowded block 2 or 3 feet away from adjoining trees. Neither good roots nor wide top can exist. Our trees are grown wide apart, and such a tree will be 12 feet from its neighbors, with wide, low-branched top and perfect root system. The latter is worth many times the former. These trees will give immediate results. They are not mere promises of future shade and beauty. The large evergreen trees are 8 to 35 feet high, ro to 50 years old, and are kept in perfect condition for transplanting. The usual sizes kept in nurseries, as trees 6 to $\mathrm{I}_{4}$ feet, and evergreens I to 5 feet, we offer of the best possible grade.

\section{Arboretum and Test Orchards. Our arboretum and certain nursery} rare species of trees from Siberia, Japan, China, Europe and other temperate regions, that are being tested to determine their value here. Extensive test orchards estab. lished over sixty years ago by the late Isaac Hicks have proved that many varieties thriving inland are inferior to other sorts here. 
Location. Westbury Nurseries are located on the Jericho turnpike, a continuation of Fulton street, Brooklyn, one mile north of Westbury, on the main line of the Long Island railroad, having eighteen trains daily. We are three miles from Mineola, which has fifty trains per day and a trolley line to Freeport. Public hacks may be obtained at the stations. The good roads of the region add pleasure to a drive to inspect the beautiful flowers and trees. The rare evergreens make a winter visit nearly as interesting as one in spring or summer. Trees selected are reserved until the planting season.

Being centrally located, even trees of large size are quickly delivered by wagon to distant points-as Far Rockaway, Brooklyn, New York, Great Neck, Northport or Islip, and to more distant points by rail.

\section{Planting Season and Large Tree Mobing.}

The method of growing, digging, transporting and planting is more important than the time. With our improved methods we are moving trees, especially evergreens, all the year round. In spring the planting season begins about March $\mathrm{I}$, when frost is out of the ground, and continues until about the middle of May. Shrubs, and some varieties of trees, may be moved the last of May, and later, if a ball of earth is kept on the roots, or if they are kept moist and planted immediately. Thus newly completed houses can have hedges and shrubberies planted about them in midsummer. August and September are favorable times for planting Pine, Spruce, Boxwood, Cedar and other evergreens. In autumn the transplanting of deciduous trees may begin three or four weeks before the leaves fall. Usually, transplanting begins at or before the middle of October, and continues until the middle of December, or later. Besides fall and spring, the moving of deciduous trees may be done any mild day in winter if the ground is not frozen deeply, or if it has been mulched to keep out the frost. In winter large evergreens may be moved to advantage, as our invention saves the feeding roots outside the balls of earth. Some deciduous trees, as Magnolia, Tulip and Liquidambar, prefer spring to autumn. Evergreens without a ball of earth on the roots require spring planting. Early orders and selections are an advantage.

Business Terms. Prices are usually quoted for trees dug and loaded at the tionate to distance and expense. Large trees on a tree-mover are priced according to labor, teams and mover used, or are priced delivered, with or without assistance in planting. Stock shipped will be carefully packed in straw bales or boxes, charged at cost. Delivery to railroad is free, where our responsibility ceases. Accounts will be subject to sight draft sixty days from date of shipment. Unknown correspondents should send satisfactory references or cash with order. Money orders may be obtained for Westbury Station, Nassau county, New York.

Notification of errors in count, etc., should be made promptly, so that they may be corrected. The living of trees depends upon so many conditions of weather and after-care beyond the nurserymen's control, that it is not possible for us to guarantee trees to live after leaving the nursery in good condition, without previous special agreement and price to that effect. We desire that all our patrons should be satisfied, and, if not, we wish to be so informed promptly. No complaints will be considered after fifteen days from delivery. While we exercise great care to keep varieties true to name, in case varieties of fruit, etc., prove not true to name, we will not be held responsible for a greater amount than the original price of the trees. Late in the season we may be out of some varieties of fruit, and we will 
substitute other sizes or varieties similar in time of ripening and quality, unless otherwise ordered. In several villages orders may be left with the florists or gardeners who act as our agents, and who may plant the trees if desired.

\section{Horticultural Questions. We offer to answer inquiries as to varieties for} special purposes, as seaside or dry-ground planting, for names of trees, wild flowers, shrubs and fruits; for remedies for fungous diseases and insects; for preparation of soil for planting; for fertilizer for special crops and soils; for advice on pruning, grafting or culture; and can usually refer inquirers to books or bulletins on forestry, landscape gardening, botany, entomology, referring to these subjects. In cases where a special investigation is required, a moderate charge is made for reports.

\section{Gardening. Tree-surgery and Preserbation and Pruning of Trees and} Hedges. For tree planting we furnish competent men and foremen. For pruning Medges. trees and hedges, spraying, renovating old orchards, preserving and rejuvenating decayed or decrepit trees, repairing the damage of ice storms, or resetting trees blown over by the wind, the equipment of machinery, skilled workmen and intelligent supervision is at the disposal of our patrons.

\section{Photographs.}

The illustrations in this Catalogue are, with few exceptions, of our own plantings, and are examples of an exceptional series of photographs showing the success of our work.

To aid in solving your landscape and horticultural problems, we can show many photographs.

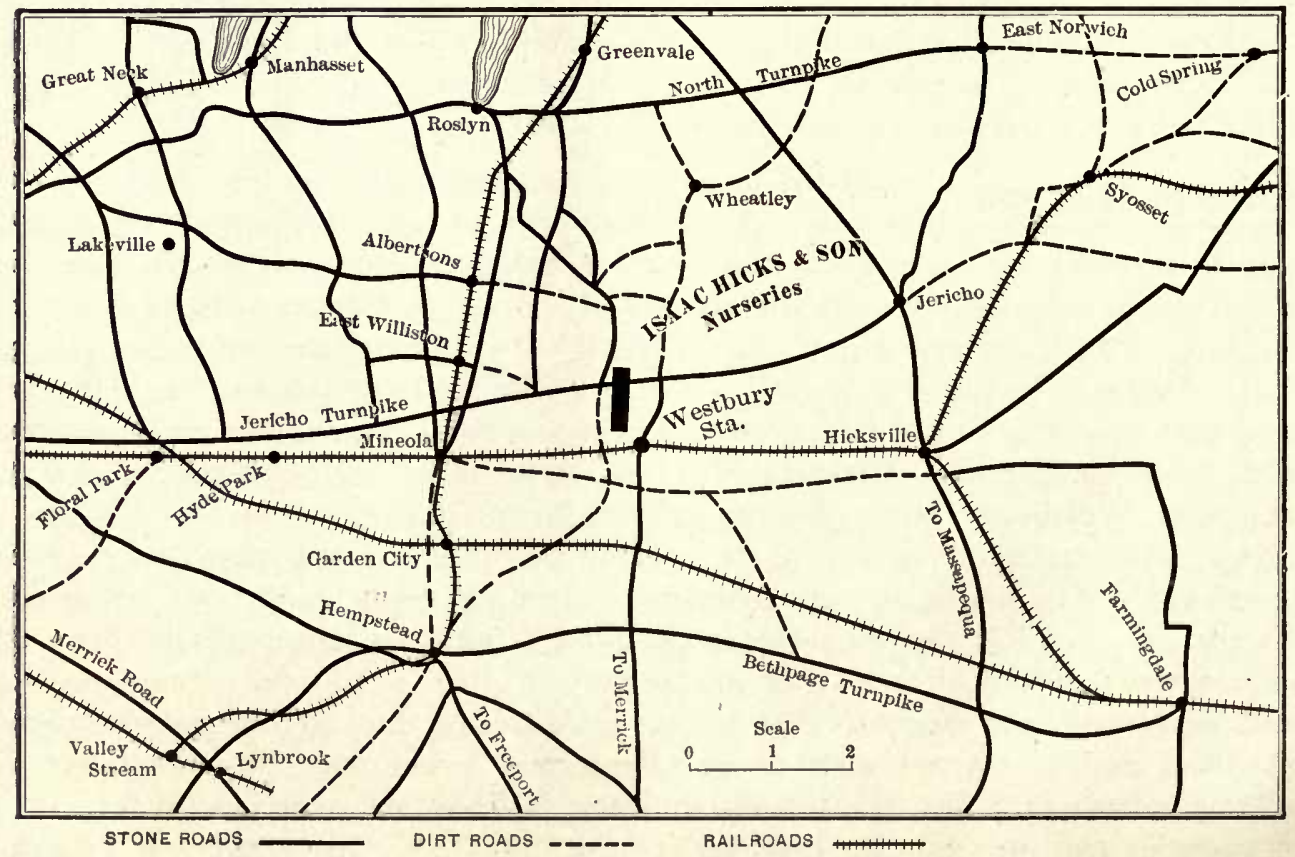

The above Map will serve as a guide to all who visit our Nurseries. 


\section{Seaside List}

\section{DECIDUOUS TREES}

Sycamore Maple,

Norway Maple,

Red Maple,

Oriental Plane,

Wild Cherry,

Red Cedar,

Austrian Pine,

Scotch Pine,

Indian Currant,

Privet,

Marsh Elder,

Rugosa Rose,

Trailing, or Memorial

Rose,

Carolina Rose,

Virginia Creeper,

Japanese Honeysuckle,

Japanese Ivy,

Sea Sand-Reed, or Ammophylla,
Catalpa,

Japanese Poplar,

Carolina Poplar,

Pin Oak,

Scarlet Oak,
English Oak,

Red Oak,

Willow, in variety,

Yellow I,ocust,

Honey Locust,
Mulberry,

White Birch,

Canoe Birch,

Euonymus,

Ailanthus.

\section{EVERGREEN TREES}

Red Pine,

Mugho Pine,

Juniper,

White Spruce,

Douglas Spruce,

Colorado Spruce,

\section{SHRUBS}

$\begin{array}{ll}\text { Sumach, } & \begin{array}{l}\text { Spirea, } \\ \text { Bayberry, }\end{array} \\ \text { Beach Plum, } & \text { Blackcap, } \\ \text { High-bush Huckle - } & \text { Tamarix, } \\ \text { berry, } & \text { Barberry, } \\ \text { Upright Honeysuckle, } & \text { Elder, } \\ \text { Iilac, } & \text { Alder, }\end{array}$

\section{VINES}

\author{
Wistaria, \\ Trumpet Creeper, \\ Bitter Sweet,
}

Myrtle,

Wild Morning-Glory, Matrimony Vine.
Norway Spruce,

Nordmann's Fir,

Concolor Fir.

\author{
Buttonbush, \\ Viburnum dentatum, \\ Cornus paniculata, \\ Holly, \\ Inkberry, \\ Yuicca, \\ Bearberry.
}

\section{HERBACEOUS PLANTS}

Couch, or Quack Grass, Swamp Rose Mallow, Cactus, etc. Beach Pea,

\section{ACKNOWLEDGEMENTS}

In writing this Catalogue we desire to acknowledge the following authorities:

"Cyclopedia of American Horticulture"

"The Rhododendron"

"The Fertility of the Land"

"The Soil"

"Elementary Meteorology"

"Pleistocene Geology of portions of Nassau County and Borough of Queens"*
L. H. Bailey

E. S. Rand, Jr.

I. P. Roberts

F. H. King

W. M. Davis

J. B. Woodworth

Thanks are also due to Messrs. Veatch and Bowman, of the United States Geologial Survey, who are preparing a report on the geology and water supply of Long Island, in connection with the New York City Water Commissioners; and J. A. Bonsteel, of the United States Department of Agriculture, Division of Soils, who is preparing a map of the soil of Long lsland.

* Obtainable of New York State Museum, Albany, N. Y. Price, 25 cents.

\section{ZONES OF PLANT LIFE}

In the distribution of trees according to zones of physical climate, Long Island is in the cold temperate zone of deciduous trees. The boundaries are not closely marked. Deciduous trees predominate in the forest, as oak, beech, birch, maple, elm, poplar, chestnut, dogwood, ash, linden, hickory and tulip tree.

The native evergreens are typical of the two bordering zones. Holly, inkberry, laurel and rhododendron extend from the warm temperate zone of broad-leaved evergreens; white pine and hemlock extend from the sub-arctic zone of conifers-the cone-bearing trees with evergreen needle-shaped leaves. The warm temperate zone has winter, mostly without severe frost, and from Washington southward is characterized by broad-leavęd evergreens, as holly, live-oak and Magnolia grandiflora. The sub-arctic zone, from the Catskill mountains and Maine northward, has winters with nearly continuous frezezing and the forests are mostly fir, spruce and pine. For Long Island, evergreens must be selected from portions of these three zones most closely resembling ours, a voiding mainly those of western coasts with an equable climate; as England and Oregon, and including those of eastern coasts, as this and Japan, and the interiors of the continents, as Colorado and the Caucasus mountains, which have a widely variable climate with extremes similar to ours. See map, page I4.

Long Island is fortunate in having been, for two centuries, the testing ground of the beautiful trees of the world. Many evergreens need from 5o to Ioo years' test plant according to these tests and the following chart, and the many mistakes now made to vex the sense of bekuty or economy will be avoided. 


\section{Comparative Chart of Long Island Soil and Climate}

ELEMENTS

\begin{tabular}{l}
\hline Latitude. \\
\hline Average annual tem \\
perature. \\
Temperature in Jan- \\
uary.
\end{tabular}

Temperature in July.

Range or difference in temperature between the average of January and of July.

\section{Extreme range in winter for a week. \\ Intensity or sunshine in clear winter weather.}

\section{Annual rainfall.}

Rainfall, May to Sept. inclusive.

\section{Drought.}

\section{Evaporation.}

\section{Relative humidity, winter.}

Relative humidity, summer.

\section{Snow.}

\begin{tabular}{c}
\hline $\begin{array}{c}\text { Prevailing winter } \\
\text { winds. }\end{array}$ \\
\hline $\begin{array}{c}\text { Velocity of winter } \\
\text { winds. }\end{array}$ \\
\hline $\begin{array}{c}\text { Drying power of } \\
\text { winds. }\end{array}$
\end{tabular}

Liab!e to drought, but frequent damp winds from the ocean bring showers that hasten growth.

40 inches from the surface of water.

Low in dry northwest winds. High in damp northeast winds. High in damp south winds.

Air frequently moist from the ocean, but may be dry for a few days.

Light snow, soon melted by ocean winds or fogs, alternate with rain.

Northwest winds from dry cold interior of continent.

High, due to level surface and absence of wind-break.

High, due to high velocity and low relative humidity.
ADJACENT MAINLAND

Back from coast

Central Pennsylvania, New

York and New England

$40^{\circ}$ to $42^{\circ}$.

$51^{\circ}$

$30^{\circ}$

$7 \epsilon^{\circ}$.

$42^{\circ}$.

Less, due to absence of ocean warmth.

Slightly less.

Liable to drought.

Lake Michigan, 22 in. (Great Salt Lake, so in.)

\section{Lower.}

\section{Lower.}

Heavy snow accumulates during winter; cools the air, protects young trees and prevents the ground from freezing deeply. Few rains.

\section{Same.}

Lower, due to hills and forests.

High.

\section{ENGLAND}

$53^{\circ}=$ Labrador, British Co lumbia, Southern Alaska, Kamchatka, Eastern Siberia, Moscow.

$50^{\circ}$.

$45^{\circ}=$ Charleston, S. C. Northern California, Northern Spain, Italy.

$60^{\circ}=$ Norway, Archangel, Northern Siberia, Northern Alaska, Hudson's Bay, Newfoundland.

$15^{\circ}=$ Same as France, Spain Florida, Mexico, California, British Columbia Northern India, Hong Kong.

Much less, due to absence of cold continental winds.

Rays oblique. Less brilliant sunshine. Frequent clouds and fog.

40 inches.

I5 inches, sufficient because of less evaporation.

Does not suffer from periodical drought.

20 inches, due to moist ocean air and oblique sum rays.

High. Air nearly satu rated for part of the time.

High. Air damp.

Light.

Southwest, from warm southern sea. Moist.

Little drying power, therefore foliage does not dry out but continues dark green and luxuriant. 


\section{RESULTS ON LONG ISLAND}

Many English plants thrive here, but some do not permanently thrive or live to happy old age, because of wide range of temperature.

In freezing, sap passes out of the minute cells of the leaf and forms crystals between. In quick thawing in dry air, this dries out of the leaf, and it dies; in slow thawing, in moist air or shade, the water is reabsorbed. Ability to stand wide range of temperature is the most important test of hardiness here.

Western Europe, and western coast of United States, and British Columbia have a small range of temperature.

Eastern coasts of United States and Asia have a wide range of temperature.

Brilliant light and added reflection from snow start the sap to flow too early.

Sufficient rain on Long Island, if it can be conserved in the soil.

Usually sufficient for established trees. Water is necessary to carry up plant-food. Some lawns are starved while adjacent pastures are luxuriant.

A drought is not liable to mar the beauty of a lawn planted with proper species to fit the soil, if the trees and shrubs are nuulched.

Evaporation from foliage and from the ground is greater o11 Long Island than in England.

The prevailing northwest wind is dry, and dries out the foliage, even if frozen.

Dry air dries out foliage. There is 30 per cent greater evaporation in the open than near a wind-break.

The air, sometimes moist for a period, conduces fungus, mildew and blight.

Absence of continued deep snow causes absence of hemlock spruce and fir from our forests, as the young trees have no protection.

Renders out-of-door life in unprotected places unpleasant, and house sites cold and bleak.

High velocity gives wind great drying powers, and whips off foliage. It blows away the fine and most fertile portion of the soil.
LESSON FOR LONG ISLAND
Avoid those for extensive planting. If they produce a certain desired landscape effect, get something else to do it here which is better adapted to our conditions.

Shade rhododendrons, holly, mahonia, Euonymus Japonica, Azalea amoena, yew, by planting under oak or locust, or adjacent to pines; or shade by straw, evergreen boughs or boards.

Get plants from those regions having similar range of temperature.

Plants in each of these regions thrive in the other, and fail here. Examples: Olive, fig, European grape thrive in California.

Plants from northern Japan, Saghalin, Manchuria, Corea, thrive on Long Island, as extremes of temperature are the same.

Send us seeds and names of business correspondents explorers and missionaries, who can collect seeds of new plants.

Shade rhododendron, yew, holly, etc. Plant on the north side of buildings, other evergreen, or deciduous trees, as oak, chestnut, locust, avoiding those that rob the roots too much, as black walnut, silver maple.

Conserve rain by letting it soak in around plants. Often the grass is mowed close and the surface of the ground made smooth, dry and hard by rolling. A summer shower mainly runs off, or is taken by the grass. Keep the ground under trees dug up loose in a circle 2 feet wider than the spread of roots. Dig loose, or hoe 3 inches deep once in two weeks; or, better, keep it mulched 4 inches deep with straw, manure, thatch, salt hay, or drift from the beach. If water is needed, as indicated by the earth, or by wilting or slow growth of the tree, apply 2 to 4 inches. If not mulched, hoe the surface after watering to prevent baking of the surface and drying out. Repeat the watering in a week. Heavy daily watering may kill trees by saturating the soil and rotting the roots. Plan irrigation for a lawn, but depend mainly on humus and good culture.

Protect from wind by close planting of evergreens. It is the drying out more than extreme cold which causes winter-killing. Mulch ground, so sap can be sent up.

Water newly planted trees during a dry period; or shade and sprinkle foliage, if necessary, for a few days:

Spray grapes and other fruits, cucumbers, muskmelons with Bordeaux mixture. Favorable for evergreens:

Protect small evergreen seedlings with a light mulch. Mulch evergreens, as rhododendrons, laurel, holly, to permit sap to come up in winter. Let lower branches of evergreens protect the ground and keep cut frost.

Plant evergreens on the north, mortheast and northwest, in belts 30 to 100 feet wide or in groves of several acres. Plant closely for mutual protection. If space is limited or large trees are used, plant a single or double row and shear to produce dense foliage. Plant pine, cedar, spruce, fir, hemlock and arborvitæ. Plant small trees in March, April, May, August and September. If planted with earth on roots, plant at any time. It is not necessary to prepare the soil for extensive plantings.

A chill penetrating wind, less comfortable than colder northwest winds. 


\begin{tabular}{|c|c|c|c|}
\hline ELEMENTS & LONG ISLAND & ADJACENT MAINLAND & ENGLAND \\
\hline Other winter winds. & $\begin{array}{l}\text { South, from gulf stream. } \\
\text { Thaws rapidly and starts sap. }\end{array}$ & Relatively less. & \\
\hline $\begin{array}{l}\text { Prevailing summer } \\
\text { winds. }\end{array}$ & $\begin{array}{l}\text { Southwest, cool sea breeze; } \\
\text { afternoons and nights cool. } \\
\text { Northwest, dry, cool. }\end{array}$ & $\begin{array}{l}\text { Southwest, hot and dry } \\
\text { from over-warm south- } \\
\text { west interior; cool sea } \\
\text { breeze absent; nights hot. } \\
\text { Northwest, dry, cool. }\end{array}$ & $\begin{array}{l}\text { Northwest, from cool } \\
\text { northern seas. }\end{array}$ \\
\hline Great storms. & $\begin{array}{l}\text { Violent off-shore winds. Se- } \\
\text { verity due to level surface and } \\
\text { lack of wind-break. }\end{array}$ & $\begin{array}{l}\text { Less severe, due to pro- } \\
\text { tection by hills and moun- } \\
\text { tains. }\end{array}$ & \\
\hline Ocean current. & $\begin{array}{l}\text { Some winds from the gulf } \\
\text { stream and from the arctic cur- } \\
\text { rent reach Long Island. }\end{array}$ & Absent. & $\begin{array}{l}\text { Gulf stream warms Eıg- } \\
\text { land continually. }\end{array}$ \\
\hline $\begin{array}{l}\text { Boil. Hempstead } \\
\text { Plains, south of } \\
\text { hills. }\end{array}$ & $\begin{array}{l}\text { Fine brown loam, I } 1 / 2 \text { to } 2 \\
\text { feet deep; no stones, gravel or } \\
\text { clay. }\end{array}$ & · & 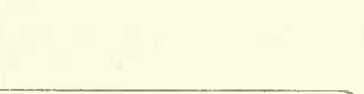 \\
\hline $\begin{array}{l}\text { Coastal Plains, east } \\
\text { of H e m s t a d } \\
\text { Plains. Pine bar- } \\
\text { rens, brush. Farm- } \\
\text { ingdale to River- } \\
\text { head. Amityville } \\
\text { to Westhampton. }\end{array}$ & $\begin{array}{l}\text { Yellow, sandy loam, contain- } \\
\text { ing fine blown sand. Surface } \\
\text { soil thin, } 3 \text { to I2 inches. Subsoil } \\
\text { for both above, coarse gravel } \\
\text { and sand, mostly quartz, which } \\
\text { is the hardest, least soluble, } \\
\text { least fertile element; a sieve } \\
\text { for water and fertility. Water } \\
\text { table, I5 to } 80 \text { feet deep. The } \\
\text { subsoil is outwash plain from } \\
\text { glacial moraine with most solu- } \\
\text { ble and fine particles washed } \\
\text { out by glacial streams or ocean. }\end{array}$ & - & \\
\hline $\begin{array}{l}\text { Soil on the hills and } \\
\text { between them. }\end{array}$ & $\begin{array}{l}\text { The hills are terminal mo- } \\
\text { raines or ranges of hills depos- } \\
\text { ited by the glacier, or ice sheet, } \\
\text { which moved across New Eng- } \\
\text { land. General surface soil } \\
\text { brown or drab loam and grav- } \\
\text { elly loam. Generally fertile. } \\
\text { Subsoil, hard-pan of clay loam } \\
\text { mixed with boulder and gravel. } \\
\text { Occasionally subsoil of coarse } \\
\text { gravel, as at Harbor Hill and } \\
\text { south slope of moraine. }\end{array}$ & & · \\
\hline Soil north of hills. & $\begin{array}{l}\text { Surface and subsoil gener- } \\
\text { ally rich loam and hard-pan or } \\
\text { boulder clay, left by glacier } \\
\text { over pre-glacial layers of sand } \\
\text { and gravel. }\end{array}$ & & \\
\hline $\begin{array}{l}\text { Soil of Far Rocka- } \\
\text { way Péninsula, } \\
\text { Lynbrook, Cedar- } \\
\text { hurst, Barnum Is- } \\
\text { land. }\end{array}$ & $\begin{array}{l}\text { Thin yellow loam, poor in } \\
\text { fertility. Subsoil coarse quartz } \\
\text { gravel, like glass marbles. Not } \\
\text { much sand between. Not gla- } \\
\text { cial in origin. }\end{array}$ & & * \\
\hline $\begin{array}{l}\text { Soil of Southampton } \\
\text { and vicinity. }\end{array}$ & $\begin{array}{l}\text { One of the two moraines left } \\
\text { by the glaciers. Soil contains } \\
\text { boulders and clay. Soil more } \\
\text { fertile than balance of south } \\
\text { side of Long lsland. }\end{array}$ & & \\
\hline Boil temperature. & $\begin{array}{l}\text { Soil of light, sandy nature, } \\
\text { quickly drained, and warms } \\
\text { quickly, especially on south- } \\
\text { ern slopes. }\end{array}$ & $\begin{array}{l}\text { Heavier soil. Clay } \\
\text { loam with subsoil less } \\
\text { quickly drained uses up } \\
\text { heat in drying up surplus } \\
\text { water. Soil is cool. }\end{array}$ & $\begin{array}{l}\text { Soil is still cooler because } \\
\text { of same reason, and north- } \\
\text { ern latitude. Rhododen- } \\
\text { drons thrive. Too cool for } \\
\text { corn. }\end{array}$ \\
\hline
\end{tabular}




\section{RESULTS ON LONG ISLAND}

Melts snow, starts sap, thaws foliage and ground rapidly; starts peach blossoms too early, and they sometimes freeze. In February the jessamine, crocus, chionodoxa and chimnonanthus sometimes blossom.

Long Island is a most comfortable summer residence region. It has developed a type of country-house architecture, long east and west, one room deep, with wide porches and shadowy eaves, the sleeping-rooms all opening to the cool evening sea breeze, and a few large rooms below. A slight change in separating the rooms on the first floor, and the planting of shelterbelts will transform them to all-the-year residences.

Trees blown down. Near the shore foliage blown off or damaged by a deposit of salt.

The ocean currents cause most of the differences of climate noted.

Favorable to production of numerous fine feedingroots. Easy to work. Trees grow large on north border next to the hills, as at Westbury Nurseries.

The pine-barren region was not early settled, because New York City demanded the products of hay farms. It has been undervalued because not natural grass land, and blighted by fire and real-estate booms. Scenery undiversified; drainage good; healthful. Favorable for tarly vegetables. The softer and finer particles are washed out of the soil and subsoil, making a sieve for rain and fertility

Hard-pan subsoil holds up water near the surface and causes vigorous growth of trees. On the richer and moister portions, the natural growth of forest is pinoak, elm, ash, tulip, sweet-gum, sugar maple, red oak, shag-bark hickory, swamp white oak, and persimmon. On hills with gravel subsoil, the forest is black oak, scarlet oak, white oak, mockernut hickory, dogwood, black birch, chestnut, locust, cherry, white pine, cedar.

Favorable for the growth of above, and especially of locust, as the finer particles of sand, loam and potash are not washed out as much as on the coastal plain. Boulders disintegrate and furnish fertility. Good grass land, favorable for stock, fruit and the staple farm and vegetable crops. Not as early for vegetables as the more sandy south side.

Planters often discouraged at slow growth of trees not suited to soil, and deterred from planting because of high price and moderate quality of top soil. Natural forest, white, scarlet, black, post, scrub and chestnut oaks; Red maple, wild cherry, pepperidge, cedar, pitch pine, holly, bayberry, high-bush huckleberry, sumach, Virginia creeper. Poor farming land. Salt spray injurious.

More fertile soil than the balance of the south side of Long Island. Elms, Mazzard cherry, catalpa, sycamore and Norway maple thrive. Ocean winds are principal hindrance. Boulders and clay contribute to fertility.

Warm soil is favorable to the growth of most plants. The soil can be worked early in spring. Nursery and farm planting may be a month in advance of inland. Long Island is the most famous vegetable-growing region in America.

\section{LESSONS FOR LONG ISLAND}

Some tender evergreens thrive best on the north side of buildings or evergreen shelter-belts.

Admit the cool sea breeze from the southwest. Cut down tall spruce or pine mistakenly planted on the south side of farmhouses. Plant large maple, elm or oak to form a canopy over the house and porch, with a breeze-way underneath.

Trees in deep soil, low-branched and broad, are most likely to withstand storms and reach great age. A shelter of other trees is advantageous.

Trees from it transplant successfully, and continue a vigorous growth, better than from gravel and clay soil. Evergreens have numerous roots close to the stem.

Develop into the garden spot of Long Island, by scientific, modern agriculture. Fertilize; grow clover, cowpeas, alfalfa; add humus. Irrigate if necessary from abundant supply to to 50 feet below. Get quick, cheap transportation. Clear fire lanes. Establish a system of fire fighting. Educate against carelessness in setting fires. Diversify scenery by landscape forestry, developing the best existing trees and by planting. Soil is favorable to most evergreens on list.

Plant such trees and most of the evergreens on the list. Plant commercial apple orchards on hills with hard-pan subsoil, rich in potash. Plant commercial peach orchards on gravel hills and fertilize with potash. Practice landscape forestry. Locate sites by aid of contour map, which shows views over, or between, adjacent hills when cleared. Select permanent trees; leave a circle of nurse trees to be cut in five years. On the bare hills plant and prepare for residences.

Take advantage of these conditions and nearness to good water transportation for manure, and for shipping fruits and vegetables. Develop residence sites as above, with views to the Sound and with shore privileges.

Plant large trees grown cheaper elsewhere. Plant trees suited to the soil (see Seaside List). Avoid Carolina Poplar and elm. Improve soil by adding humus, by fertilizing several times per year, and by mulching, which will often suffice instead of purchasing soil. Try purchasing soil from regions of heavy clay loam by rail or barge. Plant in thick groups and thin out. Avoid prevalent methods of cutting back, leaving dead stubs.

Permits planting trees requiring fertile soil and a high development of landscape art, if shelter-belts are established. See Seaside List.

Warmth of soil favors many plants, native to southern climates,-holly, magnolia. liquidambar, yellowwood, white cedar, Chinese arborvitæ, yucca, persimmon, silver-bell, stuartia, white fringe, cactus. 


\begin{tabular}{l|l}
\hline ELEMENTS & \multicolumn{1}{c}{ LONG ISLAND } \\
\hline $\begin{array}{l}\text { Power of retaining } \\
\text { soil moisture. }\end{array}$ & $\begin{array}{l}\text { Soil is porous and it absorbs } \\
\text { and holds water by capillary } \\
\text { attraction, the best way for } \\
\text { roots. Moisture is not forced } \\
\text { to run off the surface or stand } \\
\text { in pools, as it passes through } \\
\text { porous subsoil to the main } \\
\text { spring. Tile draining gener- } \\
\text { ally unnecessary. }\end{array}$ \\
\cline { 2 - 3 }
\end{tabular}

Water-table.

Water-table in hills of hard-pan.

\section{Water-table on hills of $\mathrm{gra} \nabla \mathrm{el}$, or gravel south slope of moraine.}

Water-table on plateau north of hills.

Water-table near
Long I s l a nd
Sound.

Nitrogen contained in nitrate of soda, a m monia, fishscrap, tankage, slaughter-house $r \in f \mathrm{se}^{\mathrm{e}}$, dried blood, hair manure, stable manure.

Phosphoric acid con tained in bone, South Carolina rock, and stable manure.

Potash contained in wood ashes, kainit, muriate of potash, and $8 \mathrm{tab}$ le manure. The latter contains an insufficient proportion.
On coastal plane, south of hills. Water sinks through sand and gravel to "main spring" level, which slopes slightly to streams and ocean.

Water at surface around the ponds of surface water. Some ponds dry up in summer. Water-table near the surface on perched water-table, or land springs, above strata of clay or hard-pan.

Water-table deep below the surface.

Water is sometimes held up at surface by a thin layer of glacial hard-pan, or boulder clay over pre-glacial gravel or sand.

Water-tables occasionally held up by strata of pre-glacial clay, as at Glen Head, Lat tingtown, Brookville, Cold Spring Station, Oyster Bay.

Nitrogen is the most soluble, most quickly lost from sandy land, and most expensive element. On the coastal plain there are abundant native $n i$ trogen-gathering plants of the clover family. Locust trees on the north side of Long Island gather nitrogen and favor grass under them.

Not naturally abundant. Phosphoric acid forms $3 \frac{1}{2}$ per cent of the ashes of deciduous trees, and $2 \frac{1}{2}$ per cent of evergreen trees.

Not abundant. Potash is contained in feldspar, a soft crystal in granite, in clay and shale rock. Coastal plain of Long Island has been so washed and ground by glaciers and ocean that it contains little available potash. Potash is readily soluble and quickly leaches away. Long Island has been cultivated for as long a period as any land in America, and before modern methods returned fertility to the land.

\section{ADJACENT MAINLAND}

Greater power of retaining moisture, but more runs off the surface.

Water-table nearer the surface. In the alluvial valleys elm and basswood reach great size. On the hills, water held up by rock or clay subsoil gives abundant supply to hemlock, etc.

$\overline{2}$

Clover grows better Soil retains nitrogen longer. Holds manure longer.

Phosphoric acid occurs in the marl beds of New Jersey, and in phosphate rock of South Carolina and Florida.

Potash more abundant. Rocks containing feldspar, mica, clay and shale, break up under the action of frost and tree roots, and furnish potash to the soil. Phosphoric acid fertilizer and clover are frequently all that is needed.
Water nearer the surface, or the surface soil more retentive of moisture. Trees rarely go thirsty or crops suffer from drought. Occasionally too much rain keeps the ground cold, drives out the air, and retards growth.
Soil often retentive of ing and subsoiling, especially in Ireland.

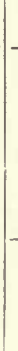




\section{RESULTS ON LONG ISLAND}

Trees do not often die from too wet soil on Long Island. It suffers less from long drought than regions with clay soil, because a porous soil contains capillary water which comes up from the subsoil.

Where water-table is over 15 feet deep, trees depend on rain and moisture held in the surface soil and adjacent subsoil.

Where the water-table is less than 15 feet deep, newly planted trees may suffer, but older trees reach the water.

Around these ponds grow pin-oak, sweet gum, pepperidge, red maple, because they can stand inundation. They will also grow on upland. Trees reaching the land springs often grow with unexpected vigor. Plants and animals requiring permanent supply of water cannot exist around the ponds that dry up in summer.

White pine is native to these gravel slopes. Elsewhere competition crowds it out.

Occasionally ponds are formed. Locust abundant. Hemlock occasional.

Above such clay strata, springs occur in narrow, sheltered valleys.

When clover is not grown the land is soon impoverished and judged poor. Trees make only 20 per cent of the growth that is possible if they are supplied with more food, and the planter is discouraged from developing the highest beauty possible.

Trees and grass make rapid growth with bone. Bone or South Carolina rock dissolved in sulphuric acid is used for vegetables. The original supply of available phosphoric acid is mostly exhausted in long cultivated land. Abundant phosphoric acid and potash induce fruitfulness and hardiness.

Fruit trees, especially peach, require potash. Apples grow best on glacial hills containing potash-bearing rocks. The fertility of some Long Island fields has been shipped to New York in crops for many years, without replenishing the land, and some fields are now abandoned.

\section{LESSONS. FOR LONG ISLAND}

Increase the moisture-holding power by adding humus, by stable manure, plowing under crimson and red clover, or rye.

Therefore, if full beauty is expected, do not plant elm trees unless there is 2 feet of good soil, and water is applied during drought.

Moisture-loving trees may be planted, but should be helped to start by deep soil preparation to encourage the roots downward. Plant red maple, beech, catalpa, elm, linden, liquidambar, tulip, magnolia, oaks, pepperidge, plane tree, willows, etc. The valleys in the plains are near water, but are very gravelly and poor. They need deeper soil, humus and fertilizer.

Elm trees may be planted and require fertilizer containing potash. If the surroundings are malarious, drain these ponds, or maintain them and stock with fish.

Plant pine groves. As a ground cover, Dwarf or Mugho pine and flat juniper are cheaper and more successful than grass.

A wide variety of trees grow successfully and develop into beautiful specimens. It is favorable for stock-farming and fruit-growing.

In such places immense black walnuts are found. In the dells and ravines plant, in addition to the hardy trees, the choicer plants that thrive better than in the center of the island, as English yew, English holly, Magnolia grandiflora, osmanthus, Andromeda Japonica, Azalea amona, Euonymus Japonica, Chinese trumpet creeper (Bignonia grandiflora), tea roses, jessamine, chimnonanthus, acuba, evergreen ferns, boxwood, English walnut.

Plant clover and plow under for manure. Sow white clover in lawns. Use plants of this family for sterile sand banks and fertilize with potash and bone. Inoculate the soil with bacteria, which grow in the root tubercles of the leguminous family and gather nitrogen from the air. Apply nitrate of soda in small quantities, one teaspoonful per square yard in April and June, or apply nitrogen in slower and cheaper form for trees, as hairmanure from Cooper's Glue Factory, or fertilizer containing fish or tankage.

Use bone in planting trees and for lawn, and dissolved bone or South Carolina rock for vegetables.

Apply potash or Canadian unleached hard-wood ashes, or fertilizers containing 4 to 8 per cent of potash. Apply at least once a year. Grow evergreens, as they require less potash than hard-wood deciduous trees. 


\section{ELEMENTS

Lime contained in
limestone rock,
burned lime, burn-
ed s hel Is and
wood ashes. \\ Humus, or decayed vegetable matter contained in wood and leaves decay- ing in the forest, in stable manure \\ - and straw, sod, clover plowed un- der, salt hay, sea- weed, etc. \\ Summary of $f \in r$. tility. \\ Other chemical ele- ments are oxygen, sili- con, carbon, sulphur, bydrogen, chlorine, fluorine, boron, alumi- num, magnesium, so- dium iron,manganese. Sufficient of these elements exist in Long Island and most other soils.}

Soil temperature, winter. Depth of freezing.

Early and late
frosts. Length of season.
Geological formation.

\section{LONG ISLAND}

No limestone rock on Long Island, but enough in most soils for plant-food. Not enough, however, to correct acid condition in some sections, which is indicated by the failure of clover and timothy, while sorrel appears. Removal of crops exhausts lime.

Small amount of humus because of long cultivation and a warm areated soil, in which the humus soon decays. Leafmold is comparatively thin in the forests, rarely over 2 to 4 inches. It is frequently destroyed by fire.

Of the $\$ 40,000,000$ annually spent in the United States for commercial fertilizers, Long Island uses as much or more than any portion, per acre, besides immense quantities of stable manure. It pays market-gardeners, because of the highly favorable conditions for quick growth of succulent vegetables and good transportation to market.

On average winters the soil is alternately frozen and thawed. On cold winters the ground is frozen deeply because of absence of snow and leaf-mold. No sap can be sent up to replace that lost by the effect of the bright warm sun and dry winds, and the evergreen foliage is dried out and partly browned.

Long growing season. Soil temperature of $45^{\circ}$ required for growth, is quickly reached in April. Early growth not often killed by late frosts, as the air is warmed by the ocean and sound, and radiation on frosty nights is checked by moist air from the ocean. In autumn the frosts are late, from the same reason, permitting late growtli of flowers.

No bed rock except near Hell Gate, Long Island City. Formation entirely of loose material deposited in the ocean and washed up by the waves, or carried on the ice and left as it melted, or washed out from the glaciers. The finer particles and most soluble portions are washed away and settle on the ocean bottom.

\section{ADJACENT MAINLAND}

Lime used to make other plant-food available, and clay soil work easier. Not necessary on Long Island.

Soil cultivated less and humus decays less rapidly. Leaf-mold accumulates because covered by snow. In summer the subsoil holds up moisture, preventing oxidization and preserving the leaf-mold. Leaf-mold in the forests accumulates, becoming 6 to 12 inches thick. It holds moisture, prevents floods, droughts, and favors the growth of young evergreens.

Not equally favorable to the growth of vegetables, but grapes, fruits, berries, grass and dairy products, can be grown profitably.

Ground stays frozen. It is not frozen so deeply under the snow or leaves. Evergreen seedlings are protected.

Shorter season. Fruit blossoms are often killed by frost. Watermelons and other southern vegetables cannot be grown so well as on Long Island. Soil often wet, cold and late. Vegetables for market not generally grown.

Bed-rock underlying most soils and slowly forming soil and adding fertility. Ledges of rocks interfere $w i t h$ digging large trees and render care necessary in selecting trees to move.
Damp, cool climate favors the formation of humus, as leaf-mold and peat.

Ground does not freeze deeply.

The change from sumner to winter is so slight that some plants native to a wider range do not ripen and are winter-killed. 


\section{RESULTS ON LONG ISLAND}

Pine trees thrive on land poor in lime. Beech trees need lime.

Rhododendrons and other plants of the heath family, as laurel, azalea, clethra, andromeda, huckleberry, will not grow on limestone soil.

Lack of humus accounts for lack of everoreen seedlings, as hemlock, fir, spruce, rhododendron, which start in it. Conditions of our soil are favorable to their mature growth.

In landscape forestry, i. e., the gradual thinning of the forest for the development of broad trees, if the leaf-mold is removed, the food and moisture supply is reduced and the trees fail.

Owners of country places fail to get economical or beantiful results from starvation of trees. Small trees suffer most because they have not a deep, wide root system. Trees and plants are most beautiful when most happy, i. e., with ample food and moisture supply.

Some evergreens are injured while young, but not when established with their roots below the frost
Apply stable manure and any available vegetable matter. Grow clover, cow-peas, vetch, rye, and plow under. Mulch around trees with leaves, thatch, manure or lawn clippings. Dig in each year and apply more. Mulch beds of shrubs; it is cheaper than hoeing.

Study the maximum growth of trees and get yours to equal it. Pin-oak, 2 feet; red oak, 2 feet; Norway maple, 2 feet; poplar, 4 feet; white pine, 2 feet. The rate of growth of the leader of young trees is greater than of older trees. Avoid too much manure and water, which makes the ground sodden and rots the roots.

Protect some species, especially when young or standing alone. Chinese arborvitæ, hemlock, Retinospora pisifera and its varieties, English and Irish yew, cedar of Lebanon, Deodar cedar, cephalotaxus, blue spirea, Andromeda Japonica, Azalea amcena, boxwood, daphne, Euonymus Japonicum, evergreen hawthorn, heather, English holly, mahonia, Magnolia grandiflora, osmanthus, rhododendron, dolichos, English ivy, tea roses. Mulch Japanese anemone, foxglove, lilies, kniphofia, sage, thyme, phlox, pinks, and other perennials.

Long Island can grow many plants that are tender elsewhere. It is about the northern limit for many southern trees-liquidambar, persimmon, white cedar, pin, post and black-jack oaks, Magnolia glauca, and holly. In the center of the island frost may kill the foliage earlier than near the shore.

Long Island soil averages more sandy than mainland. Sand and rock-dust blown in from boulders on the sound shore, as at Dosoris, Bayville and Oyster Bay, form the fertile asparagus soil. Fine beach sand blown over the pine barrens is pure quartz and not fertile.

Take advantage of the exceptionally favorable Long Island conditions and develop the highest beauty of the landscape. If growth is started when you order, buy from a near-by nursery, where the trees are grown and dug with numerous fibrous roots. Prune and remove part of the foliage, transport and plant carefully and quickly. The warm soil quickly starts new roots. Planting may thus continue in May and June. Shrubs may be planted with balls of earth.

The moraine soil and flora resembles the adjacent mainland. The coastal plain soil and flora is distinctly southern and resembles the coastal plain from New Jersey southward. Select for permanent planting trees especially adapted to these conditions. 


\begin{tabular}{|c|c|c|c|}
\hline ELEMENTS & LONG ISLAND & ADJACEN'T MAINLAND & ENGLAND \\
\hline $\begin{array}{l}\text { Alluvial river bot- } \\
\text { tom, with deep, } \\
\text { rich soil, receiv- } \\
\text { ing, in present or } \\
\text { past, a deposit of } \\
\text { rich mud from the } \\
\text { upland, a n d an } \\
\text { abundant water } \\
\text { supply. }\end{array}$ & $\begin{array}{l}\text { On Long Island some places } \\
\text { approaching these conditions } \\
\text { have deep, rich soil and an un- } \\
\text { failing water supply under it, } \\
\text { or at one side. These condi- } \\
\text { tions, with two and a-half cen- } \\
\text { turies of cleared land, have } \\
\text { developed noble low-branched } \\
\text { oak, black walnut, ash, maple } \\
\text { and beecl. There are few } \\
\text { alluvial valleys. The wet soil } \\
\text { is often thin, with the fertility } \\
\text { washed out. }\end{array}$ & $\begin{array}{l}\text { Mainland has many } \\
\text { such alluvial river bot- } \\
\text { toms whereadjacent river } \\
\text { or rock holds water with- } \\
\text { in reach, and there the } \\
\text { magnificent elms develop. }\end{array}$ & $\begin{array}{l}\text { England possesses more } \\
\text { latge old trees than any } \\
\text { other country, because of } \\
\text { moist ricl soil and a tree- } \\
\text { loving people who have } \\
\text { cared for ancestral trees for } \\
\text { centuries. }\end{array}$ \\
\hline $\begin{array}{l}\text { Contour of hills and } \\
\text { valleys. }\end{array}$ & $\begin{array}{l}\text { Generally flat, except two } \\
\text { ranges of low wide hills of gla- } \\
\text { cial moraine I50 to } 380 \text { feet } \\
\text { high, and these have generally } \\
\text { gentle slopes, as there are no } \\
\text { active streams at their base } \\
\text { cutting the valleys deeper. On } \\
\text { the south shore there are no } \\
\text { hills to check the warm soutl } \\
\text { winds whichstart growth early. } \\
\text { On the north shore there is the } \\
\text { same result over a narrower } \\
\text { strip. }\end{array}$ & $\begin{array}{l}\text { Deep valleys and steep } \\
\text { hills, with a difference in } \\
\text { climate on the north and } \\
\text { south slopes. Deep nar- } \\
\text { row valleys and ravines } \\
\text { in which some evergreens } \\
\text { tlivive. }\end{array}$ & $\begin{array}{l}\text { In deep sheltered ravines } \\
\text { on the south and west coast, } \\
\text { pilnis grow outside in } \\
\text { winter. }\end{array}$ \\
\hline $\begin{array}{l}\text { 8alt spray, coast } \\
\text { wind s, driving } \\
\text { sands. }\end{array}$ & $\begin{array}{l}\text { On Rockaway, Montauk and } \\
\text { Orient peninsulas, resistance } \\
\text { to salt spray is a controlling } \\
\text { factor in landscape develop- } \\
\text { ment. On the shore of Long } \\
\text { Island Sound and Great South } \\
\text { Bay it is important for a belt } \\
\text { along the shore. To some } \\
\text { plants velocity of the wind is } \\
\text { more detrimental than salt or } \\
\text { sand. }\end{array}$ & & $\begin{array}{l}\text { Salt spray is present on } \\
\text { the coast, but the climate is } \\
\text { so different that lists recom- } \\
\text { mended there do not gener- } \\
\text { ally thrive here. }\end{array}$ \\
\hline $\begin{array}{l}\text { Ice storms, coating } \\
\text { tree branches and } \\
\text { wires } 1 / 8 \text { to } 1 / 2 \text { in. } \\
\text { with ice. }\end{array}$ & $\begin{array}{l}\text { The Atlantic coast is subject } \\
\text { to such storms because of wide } \\
\text { variation of temperature. The } \\
\text { immediate cause is rain follow- } \\
\text { ing a period of clear, cold } \\
\text { weather. }\end{array}$ & & \\
\hline
\end{tabular}

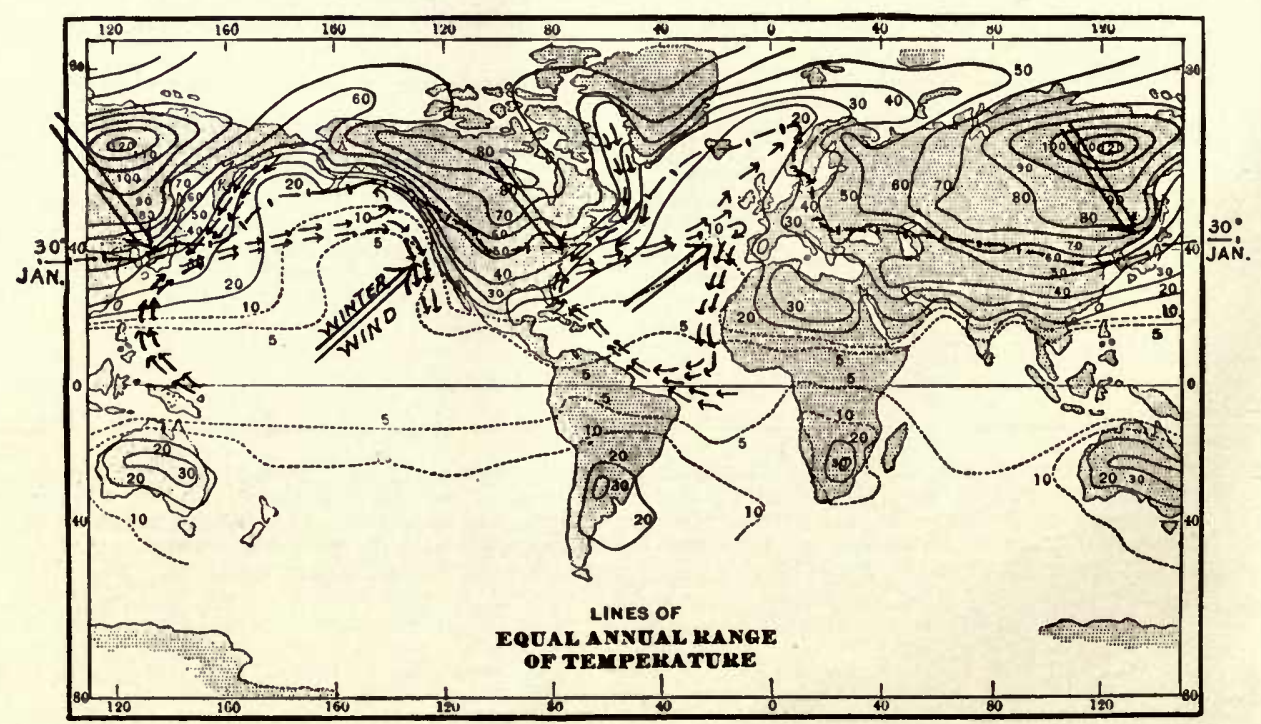




\section{RESULTS ON LONG ISLAND}

For river bottom land nature has developed a special type of tree with surface roots, unaccustomed to a strenuous effort to obtain food and water. Alder, ash, elm, Kentucky coffee tree, Carolina poplar or cottonwood, willow, American buttonball and arborvitæ are types. Some trees from alluvial soils thrive also on upland, and others do not permanently thrive. They generally have soft, weak wood that is easily broken and quickly decays. Trees of this type form the chief list of nurseries, because they multiply cheaply, grow rapidly, live when transplanted with short roots or small ball, or when dried in shipment, and supply the demand for cheap trees that make a good show the first year.

Owing to slight diversity, there is but small advantage in one slope over another, for influence of frost on fruit blossoms, etc. On the north and south shores Hydrangea Otaksa ripens its flower-buds slowly and lives outside. In the center of the island the flowerbuds are killed.

\section{LESSONS FOR LONG ISLAND}

For permanent planting on the thinner upland soils of Long Island, avoid such trees unless quick, cheap results only are desired, and the requirements as to food and water will be met. If planted, put the permanent trees between. For the drier upland, nature has developed scarlet, black, post and black-jack oaks, mockermut hickory, white birch, chestnut, wild cherry, red cedar, pitch-pine, white pine. It needs special skill, patience and thoroughness to grow and fit this type of tree for successful transplanting.

Make artificial ravines by planting bays of large evergreens in the shelter of which less hardy plants may be grown. Take advantage of shelter of buildings, fences, hedges, orchards. Old orchards may be transformed into landscape features by planting shadeenduring species under them. To screen a stable through the woods, an artificial ravine with high banks of rock and soil may be made and planted with hemlock, yew, fir, rhododendron, evergreen fern, etc.

Follow nature. Plant trees and shrubs 2 to 5 feet apart in belts 20 to 100 feet wide; keep foliage compact; fertilize little and often; manure or mulch heavily, or cover the ground with brusli: put low hardy shrubs on the windward side, and back of them the taller trees and shrubs. In some cases build a board fence for winter or all the year. Solve each problem according to (Ist) conditions of exposure, moisture, soil, fertility and available soil to add; (2d) purpose, as low cover, tall shade, to hold drifting sand, or cover sand biuff; (3d) time when results are wanted, in one to two years or six years. See list for seaside planting.

Prune the wounds close to the trunk and keep painted till bealed to prevent decay. To check the tendency of old white pines to break, let the lower branches rest on the ground and shorten the upper branches and strengthen by wires. With silver maples and elms, plant trees trained to a single leader, or bolt the crotches.
Branches of trees are badly broken. The wounds may prove fatal, especially on broad spreading trees, where the wound is near the trunk. Silver maple, old apple trees, old white pines and elms are prone to damage.
Many seaside places are bare and bleak, and much of their property because they plant a few scatt
trees of varieties not adapted to their conditions.

\section{EXPLANATION OF MAP}

Map adapted from Elementary Meteorology, by William M. Davis, Professor of Physical Geography in Harvard University.

The numbered lines show the number of degrees of difference or range between the average temperatures of January and July.

Long Island and Northern Japan are on line $40^{\circ}$; England and coast of Oregon on $20^{\circ}$.

- - - - line of average January temperature of $30^{\circ}$, passing through Long Island, Colorado, Japan, Caucasus, Germany and Norway.

Small arrows, cold and warm ocean currents. Large double arrows, prevailing winter wind from warm ocean current to coast of England and Oregon, and from dry cold interior to Long Island, Japan and coast of Manchuria.

Japan is more protected by mountains on the mainland than Long Island. Southern Japan receives more benefit of warm ocean current than Long Island, otherwise their climates are very similar. 


\section{Landscape Architecture}

HENRY Hicks, Cornell University, College of Agriculture.

Harold Truesdel Patterson, of Harvard School of Landscape Architecture.

ARNold P. KOHLER, Civil Engineer.

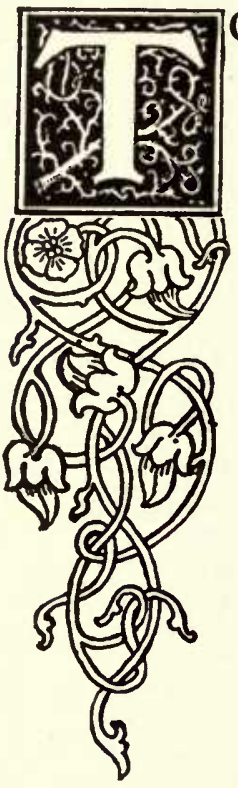

those desiring landscape advice we offer our services for all classes of artistic work in connection with the landscape development of grounds surrounding private dwellings in city, or suburbs, or country; on new estates, or the renovation of old estates, either large or small; parks, and landscape forestry, and to make detailed reports on special problems in connection with landscape architecture.

The method of procedure necessitates a visit of examination, to determine the proper treatment of the property; as the location and orientation of the house, stable and outbuildings; subdivisions, as lawn, flower and vegetable gardens, service and laundry courts; the courses of the drives and walks; the arrangement of groves of trees and shrubbery for the beauty of form and color in the house picture, in framing distant views, and in screening objectionable features from sight. Plans, specifications, estimates and superintendence of construction are furnished in connection with this work.

It is obviously clear that the Landscape Architect should be employed from the beginning, to give the dwelling the proper relation to views, divisions of the property, necessary approaches, natural drainage and prevailing winds. The house should be placed to fit the ground, and all approaches, divisions and views should be planned for before the house is built. The ideal design makes a single unit or composi- 
tion of the house and all the parts surrounding it; the house fits the grounds; the drives and paths approach correctly; and the various other buildings are arranged to suit the peculiar needs of that particular place. Convenience and beauty are the primary qualities of a good design.

We can lay the foundation of this work for you by submitting plans and advice, for the present and future, for the working out of a definite and tangible ideal toward which all steps may progress.

Landscape forestry as applied to Long Island conditions is the slow and systematic development of the trees in the closely growing, monotonous woods into a diversified and interesting forest of wide-spreading trees, which show the characteristic beauty of their species. This development of the woodland is obtained through judicious selection of the trees to remain as the future forest, and gradually preparing them for changed conditions. These are naturally those kinds best-suited to produce the picturesque results suggested by the situation. The aim is to obtain the fullest degree of forest beauty under existing conditions.

There are many excellent residential sites, now shut in and unattractive, which may be developed in three to five years by Landscape Forestry and by clearing the woods for future lawns, vistas and breezeways.

We are prepared to make reports on landscape problems, forestry, seaside planting and horticultural questions.

The fees for these services are reasonable, varying with the classes and conditions of work.

\section{ISAAC HICKS \& SON \\ Westbury Station, Long Island, New York}




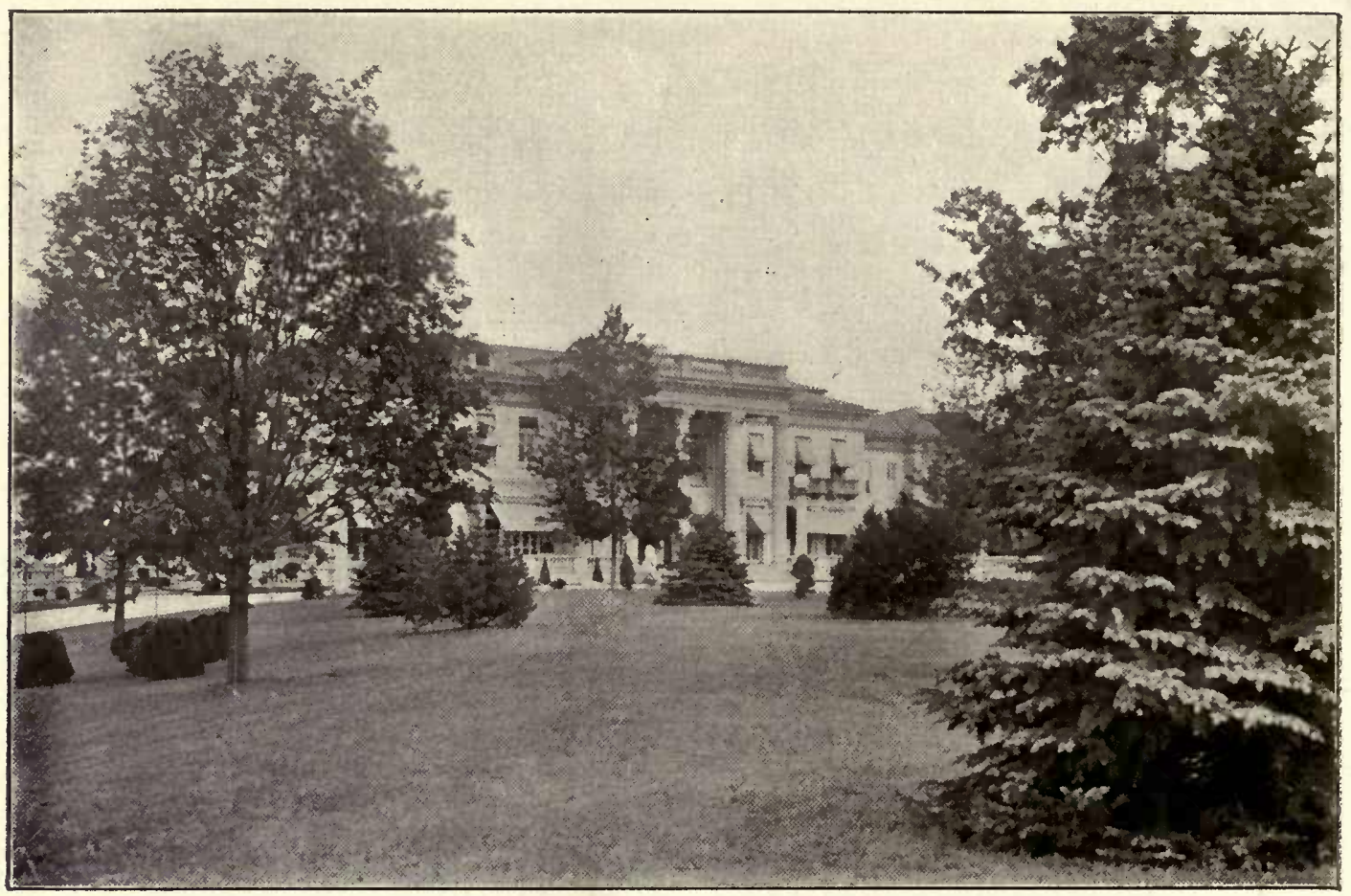

Landscape of Norway and Scarlet Maples, Colorado Blue Spruce and Boxwnod. A complete planting by means of the Tree-Movers on a site cleared from a dense forest. "Meudon," the estate of Mr. Wm. D. Guthrie, Locust Valley, L. I. Photographed fifteen mouths after planting.

\section{The Moving of Large Deciduous Trees}

The invention of our Tree-movers in their present perfection is the result of a slow growth. Thirty-five years ago this firm moved trees of large size, some of the first being to the then new arboretum of the late Charles A. Dana, at Dosoris, and others to the village of Garden City, then

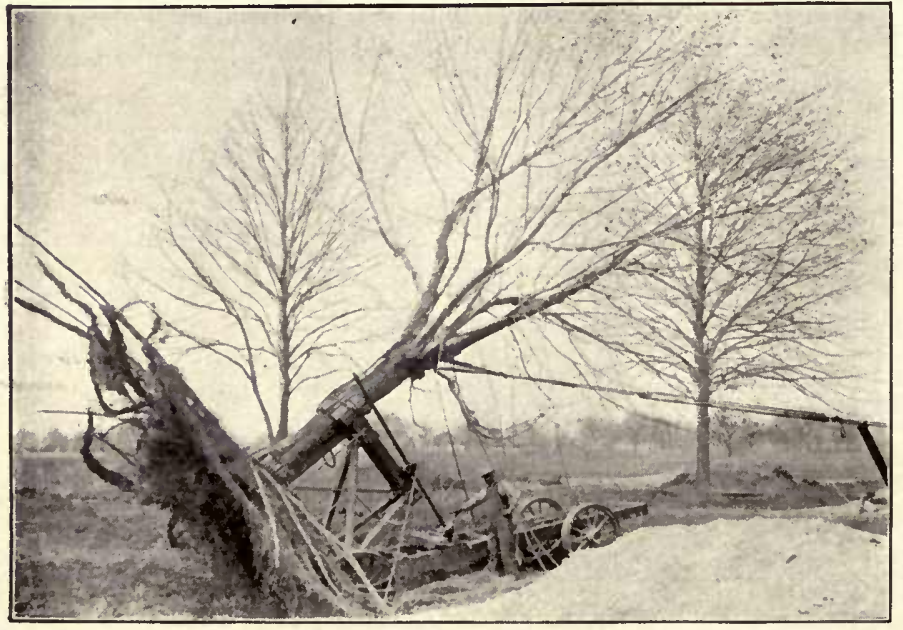

One of the Hicks' Patent Trea-Movers. - We have invented the method of digging which preserves the small feeding roots. The roots have a sprea of 30 or $40 \mathrm{feet}$. After digging, the tree is grasped by the hinged cradle and swung over horizonlally by a screw. In this position trees may pass under electric wires.

After the outer feeding-roots are freed the tree is undermined and the central ball of earth, 7 to 12 feet in diameter, cleaved from the subsoil. This central ball of earth contains nainly the large being built on the treeless prairie of the Hempstead Plains.

We have made a vast improvement as regards the size of tree which can be moved, and in the economy and safety of the method. The far-famed stone roads of Long Island have been an important factor in the development of treemoving, aiding in transporting such heavy weights twenty to fifty miles.

The moving of a tree is a surgical operation. The small roots are its connected from the original site and re-established. The moving requires expert and careftil operators to pick out the small roots. of the tree. From these small roots branch out the root-hairs and rootlets which gather up the food and water. feeders; in moving they are dis- 
roots, which act as pipes to carry the sap, and as braces. This ball contains only is to 25 per cent of the feeding-roots, while with our method the full circle, 3 o to 40 feet in diameter, is preserved. While some large trees may live a few years, or gradually recover, the method of moving with only is to 25 per cent of the roots is not to be recommended.

The operation of loading a large deciduous tree, as a Maple or Linden, on a HICKS PATENT TREE-MOVER, is to swing the cradle forward till it touches the trunk, which is attached so as to avoid injury to the bark. The tree

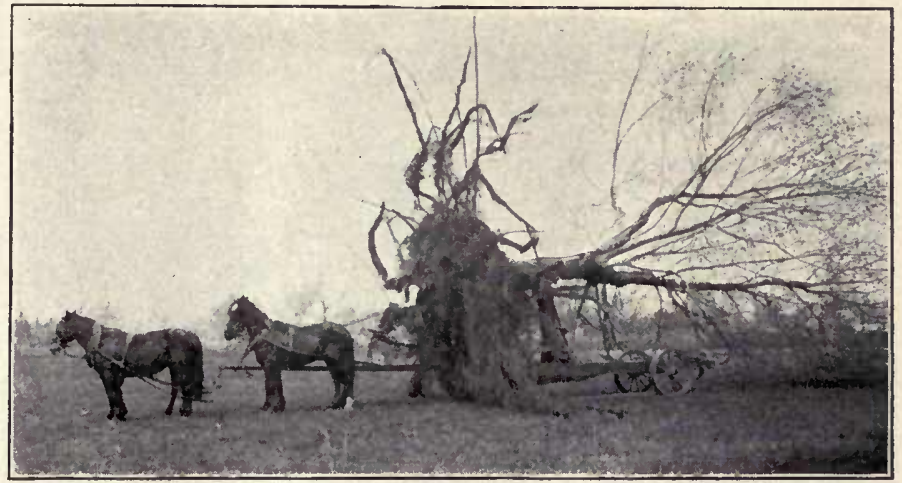

Ready for the Road. - The tree is loaded with shortest branches and roots on top, so it can go under electric wires, which are lifted by a T-pole. Four to eight horses or traction engine, broad tires, and planks over lawns, enable heavy trees to be moved. Rope and tackle or windlass are also used in difficult places.

is picked up and laid over on its side by the screw and tackle. The front of the cradle is inclined, to carry the weight over the front axle. The roots on the under side are tied up under the mover, there being no danger of breaking them by swinging of the axle, for the axle is stationary and the wheels are on pivots. The roots are parted for the pole and seat to be inserted, and the tree starts upon its journey.

When the roots are to be out of the ground for sone time they are wrapped, to prevent drying.

In planting, the operation of loading is reversed and the roots replaced in the earth in their natural position. Great care is necessary to get the roots properly enclosed in soil and at the right depth below the surface.

While nature generally supplies food and moisture, additional amotnts judiciously applied result in rapid, dense growtit. An overdose of food and water may have injurious results in causing the ground to sour and the roots to decay. The ground should be moist, but not wet and sodden with

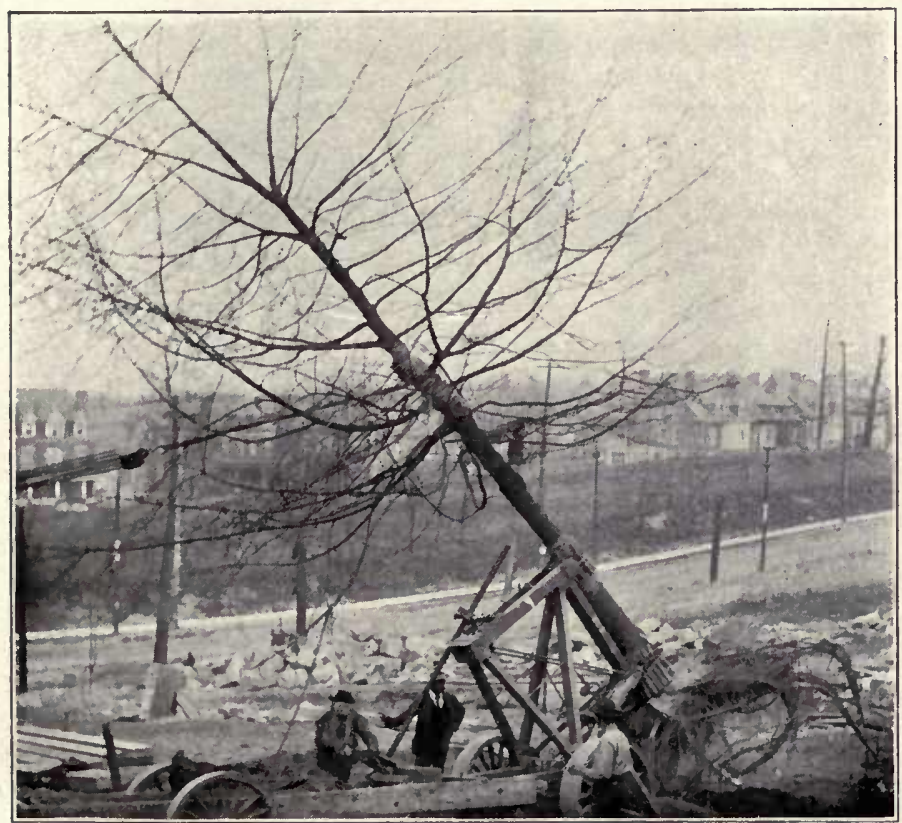

Moving large trees from the site of the new Carnegie Institute in Pittsburg to the lawn of Mr. W. L. Mellon, in the same city. water. Air should fill the soil spaces. Under-draining in heavy soils is advisable. Watering with one inch of water once a week during a dry season, and conserving the moisture by a mulch of four inches of strawy manure, or hoeing to keep the surface soil loose, is best. After the roots get to work in summer, and in succeeding years, additional food supplies should be given. In short, the most favorable conditions are those of a successful potato field or flower bed.

We have now reduced the moving of large trees to a science, with more certain results than with small trees.

Tree-novers sent anywhere with crews of expert men and portable house. We will look up suitable trees within forty miles of any point and submit photographic report of cost of moving, and of preparing if necessary.

To demonstrate the success of our methods we offer to plan a trip and show some of the 2,000 trees moved with our twelve Treemovers of various types. 


\section{The Moving of Large Evergreen Trees}

The moving of large evergreen trees requires a somewhat different method, owing to the fact that their foliage is constantly calling on the roots for moisture, and therefore a large proportion of

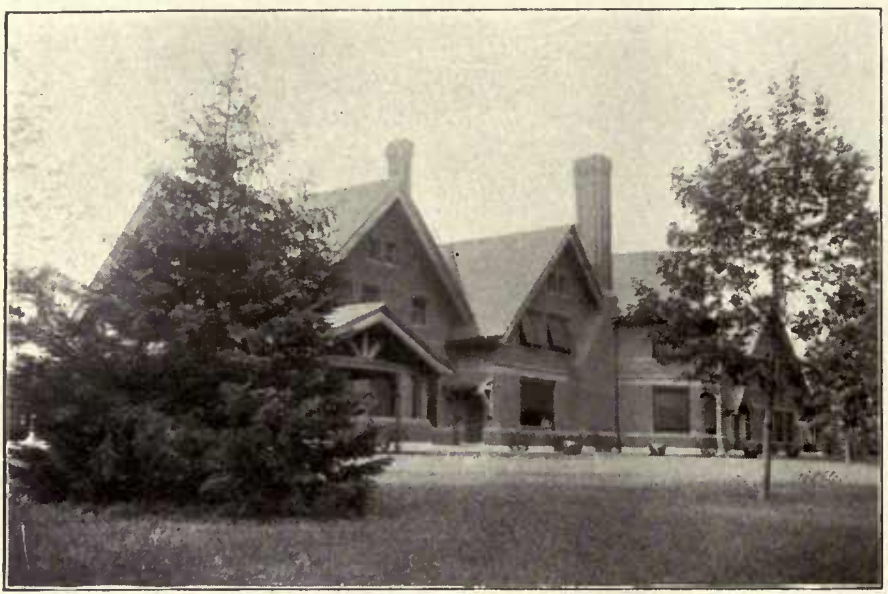

White Spruce planted by the residence of the late Hon. William C. Whitney, Wheatley Hills, L. I. At the right, an extra-sized Norway Maple. the roots should be in undisturbed contact with the soil.

The resinous sap of the roots is hardened if the roots are exposed for a few hours, and does not readily circulate again. The roots of a deciduous tree are not injured nearly as quickly by exposure to the air, and it is not necessary to keep them in contact with the soil. The methods we have invented safely hold the mass of earth solid even when the soil is of gravel and easily broken. The outer feeding-roots are preserved and not exposed to the air.

While it is not possible to move an evergreen 50 feet high with as small expense as a maple, still trees 20 to 35 feet are economically and safely moved, and many hundred large evergreens we have moved demonstrate the success of our method.

The series of photographs inadequately portrays achievements in producing landscape beauty heretofore believed impossible. The painter, sculptor, architect and musician attain results on the completion of their work. The landscape architect may now do the same, instead of waiting fifteen to fifty years. One of the most difficult tasks in composing a landscape is to screen adjacent houses, stables, roads and other objectionable features. This may be done by planting large trees, and then the balance of the landscape and water views often compose themselves into most satisfactory form. This problem of screening adjacent property has thus been most happily solved in the many colonies of country residences on the shores of ILong Island, avoiding the vexatious

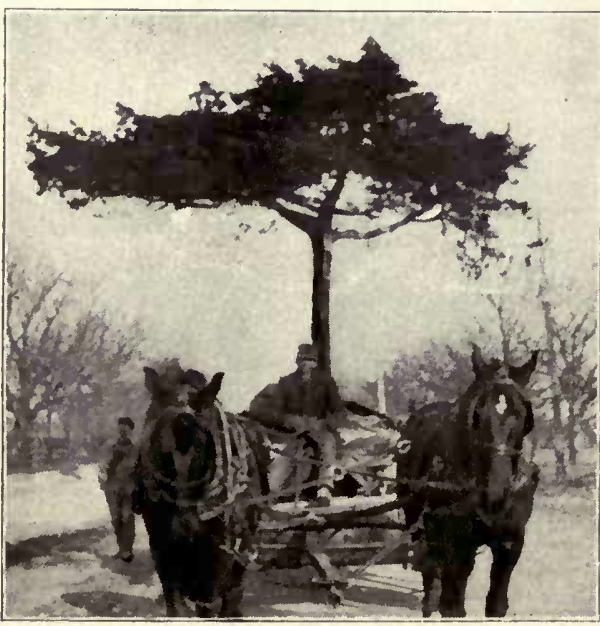

A picturesque Japanese effect. Cedar being moved for Mr. Robert L. Stevens.

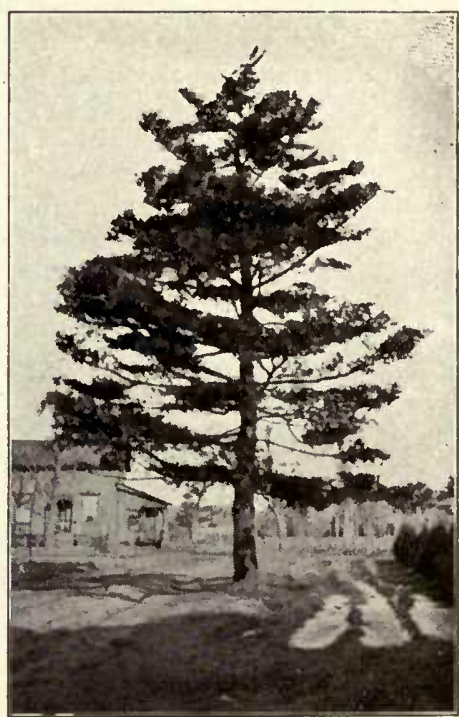

One of twenty White Pines, 25 to 45 feet high, prepared for moving on our Mover No. I3, one of the two we have invented for moving these trees horizontally. home.

A windbreak of Pine, Spruce, Cedar and other evergreens on the north side of a residence, terrace, forma] garden or lawn, render possible out-of-door life on bleak, cold and windy winter days.

The demand for large evergreens to embellish fornal gardens and give a mature and finished appearance has led to our training them in symmetrical form for vistas, terraces and decoration of old-fashioned gardens. 


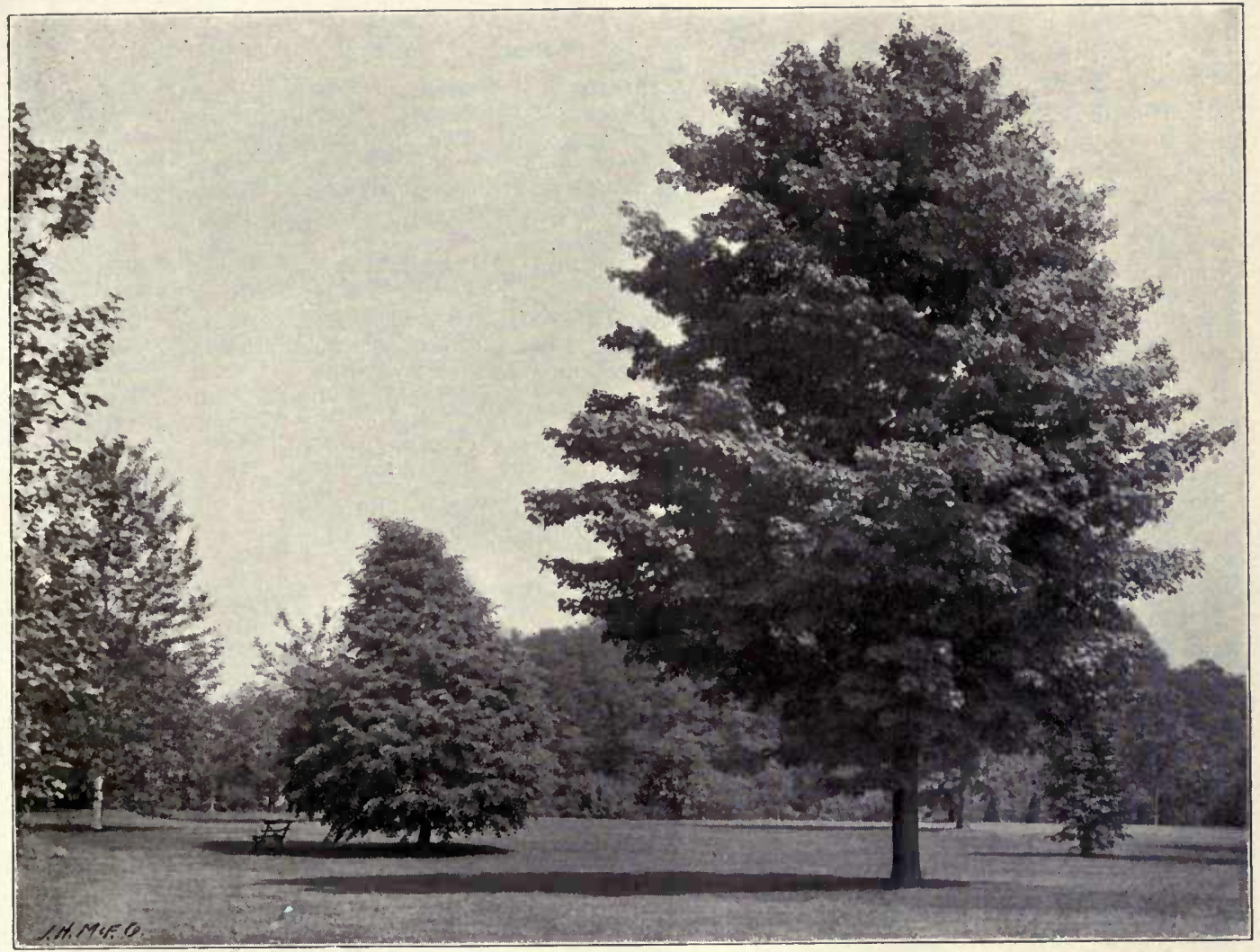

Large trees moved to the lawn of Mr. Edmund Wetmore, Glen Cove, in 1893 , demonstrating the fine growth of the trees. Sugar Maple on the right, small-leaf European Linden in the center, and Japanese Poplar on the left.

\section{Deciduous Trees}

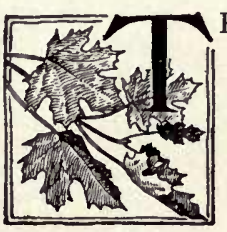

HE ornamental shade trees that we recommend for their landscape value as fine lawn specimens and avenue trees are the Beech, Catalpa, Llm, Linden, Liquidambar, Maple, Oak, Poplar and Tulip. Most of these are available to our patrons in sizes ranging from the ordinary nursery tree of 6 to 14 feet, to specimens up to 40 feet or more in height and 30 feet spread of branches.

Having the advantage of soil that causes a tree to produce a compact mass of fibrous roots and giving them special culture, the large trees we. offer are in perfect condition for successful transplanting.

We invite a personal inspection of our blocks of large trees, especially during the summer, to make selections that will be reserved till the planting season.

For extensive street planting we call attention to the Norway and Silver Maples.

In the following pages it is our aim to so describe the different trees that the purchaser may readily decide upon the best trees for his purpose, considering climate, fertility and moisture of the soil, and exposure.

The system of nomenclature is to give the conmon or English name whenever that is best known, followed by the Latin or botanical name as given in the Cyclopedia of American Horticulture, and such botanical synonyms as have been in recent use.

We have developed a method of producing numerous fine flexible feeding-roots close to the stem, and a method of digging and carrying which preserves them. For shipment by rail we offer trees thus prepared, up to 35 feet high, loaded on open cars and boxed over.

Price, 50 cts. to $\$ I$ each, and upward. Trees cf extra size and quality, $\$ 1$ to $\$ 3$ each, and upward. Quick-growing trees, such as Silver Maple, Catalpa and Poplar, 20 to 50 cts. each. Prices are subject to change according to quality, size anò quantity. 


\section{BIRCH. Betula}

The Birch family contains some indispensable elements of landscape decoration, among which the White and Canoe Birches stand preeminent. Gracefulness is the predominant characteristic. They transplant readily; adapt themselves to soil both wet and dry, fertile and impoverished. Members of the Birch family are nature's pioneers in establishing forests on impoverished soil. It has won the admiration of poets and artists. Scott has called it "the lady of the woods."

European White. $B$. alba. The most commonly known species and extensively planted in cultivated grounds; usually growing with a straight, slender trunk clothed with white bark. We have low-branched specimens 30 feet high.

Cut-Leaf Weeping. $B$. alba, var. pendula laciniata. This is one of the most beautiful and graceful of all trees, especially in the fern-like arching sprays. Unfortunately it sometimes loses its lower branches in this region.

American White. B. populifolia. This is the species native to Long Island, growing freely in sandy and poor soil. It has one or several graceful white trunks. Large specimens can be supplied.

Canoe, or Paper. B. papyrifera. This is a large, strong tree. The pure white bark was used by the Indians for canoes. The leaves are broader than those of the other white Birches. We can recommend it for general planting.

Cherry, Sweet, or Black. B. lenta. The bark of this species is like that of a young cherry tree, ot a reddish brown and smooth. It forms a tall, broad-spreading tree of vigorous health. The twigs have a pleasant aromatic flavor.

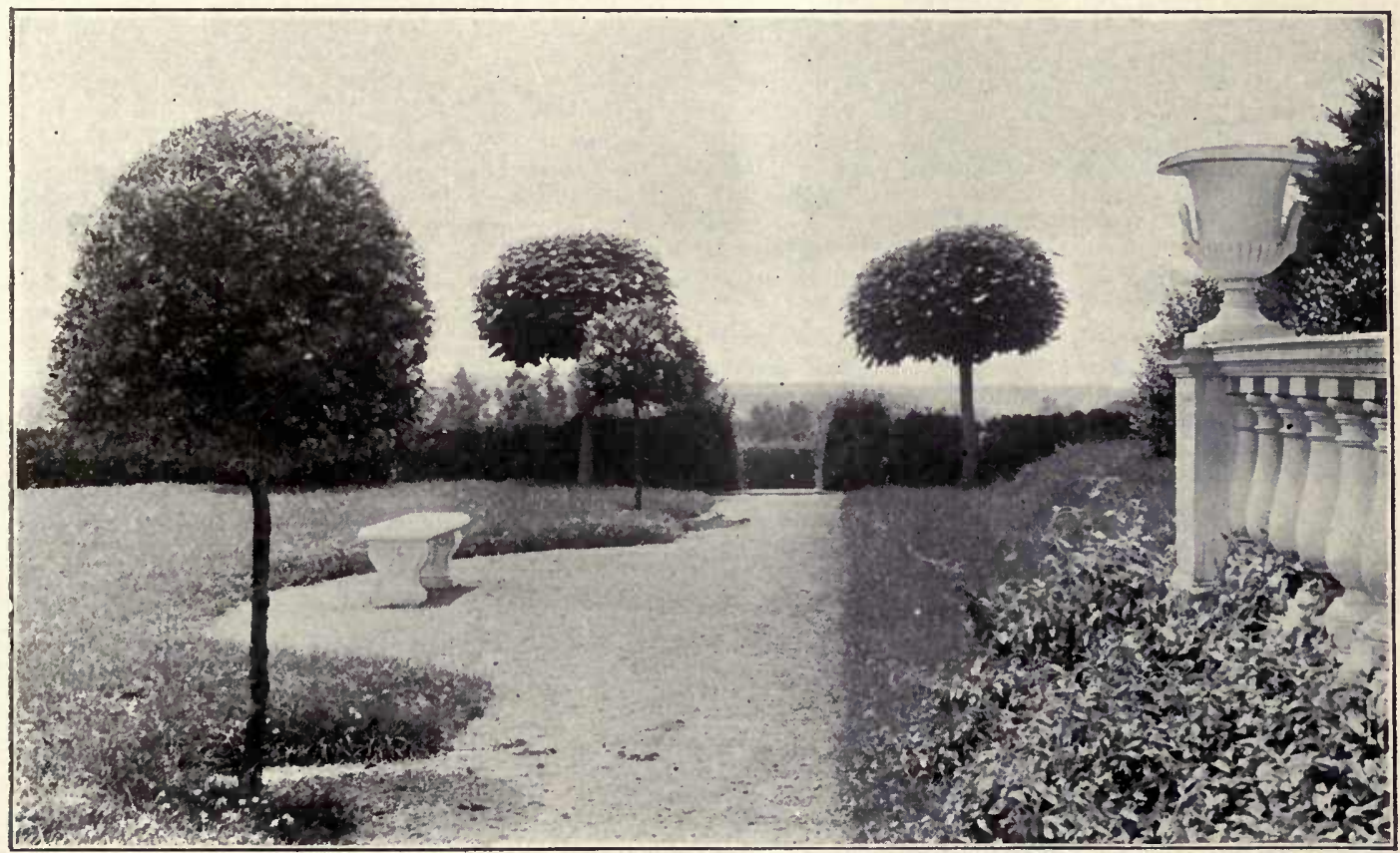

Standards of Privet and Catalpa Bunget on the terrace at the residence of Mr. Hamilton Carey, Westbury, L. I. We have in stock several hundred of these trees 5 to 6 feet in diameter, with heads and stems accurately and uniformly tiained.

\section{CATALPA}

Western. C. speciosa. This is a rapid-growing, upright tree with very large leaves. In July it bears flowers in clusters a foot wide, more showy than the horse-chestnut. Its sturdy, healthy and handsome appearance even near the ocean has won it many friends. It has no bad habits and is superior to the Southern Catalpa formerly planted. The foliage appears late. We offer large specimens up to 30 feet high.

C. Bungei. C. bignonioides, var. nana. BAy TREE FORM. In formal gardens and on terraces the standard form combines as well with architecture as the Bay Tree. It has a compact, globular head, maintaining its form even under unfavorable conditions. It grows vigorously two feet per year. On a small lawn a pair may be appropriately placed on either side of a path or at a gate. Having devised a new system of training standards, we have the best possible quality of this and other standards, as Privet, Boxwood, Cedar, Laurel, Willow, etc.

SHRUB FORM. Suitable for seaside shrubberies. Described under Shrubs.

\section{CERCIDIPHYLLUM. Kadsura Tree}

c. Japonicum. A new Japanese tree of large size, similar in form to our tulip tree. The leaves are small, and, when starting from the bud, are a translucent pink, and as pretty as a spray of flowers. 


\section{CHERRY. Prunus}

Double-flowering Japanese. P. Pseudo-Cerasus, var. Sieboldi. The double flowers are pink and white, with fimbriated edges, and make a beautiful display in spring.

Japanese Weeping Rose-flowered. I. pendula. The single pink flowers are in such profusion on the graceful, pendent branches that they give the appearance of a pink mist or veil thrown over the tree in early spring. It is a decided acquisition to our flowering trees and produces a handsome effect on the lawn.

wild Black. $P$. serotina. In searching for a tree which will grow upon the sand dunes and meadow edges of the south side of Long Island, this tree has been found of high value. It grows there vigorously, forming a noble broad tree with foliage glossy and healthy, rivaling the privet. The fruit is like a small bunch of grapes and is used medicinally. In the interior of the island it grows to a troublesome extent along the fences.

\section{CHESTNUT. Castanea}

American. C. Americana. In the open the Chestrut quickly develops the same appearance as the noble and wide-spreading English or white oak. It should be used not only on lawns, but for park planting and in fields and pastures. In the forest each Chestnut crown stands out distinctly in July, covered with cream-colored tassels. For the large fruiting varieties, see Nut Trees.

Spanish. C. savita. The Spanish Chestnut, some varieties of which are hardy, is a tree of similar appearance to the American. The nuts, especially of the improved varieties, are much larger.

Attempts to cultivate it here illustrate the importance of getting hardy varieties, for many either die when young, or in old age look unhappy.

\section{CHESTNUT, continued}

Japanese. C. crenata. As a lawn ornament this. species takes high rank and may be considered intermediate between a tree and a shrub, for while young it branches close to the ground and forms. a round-headed mass of handsome foliage. The fruit is I to 2 inches in diameter and borne often the first year after planting. Not so sweet in flavor as the American Chestnut.

\section{CYPRESS. Taxodium}

Deciduous. $T$. distichum. It is a pyramidal tree of fleecy light green foliage. Its conical spiry top and the contrast in foliage to all other deciduous trees call for its occasional use. In appearance it resembles the larch, another member of the Pine family which drops its leaves.

Chinese Weeping. T. distichum, var. Imbricarium; syn., Glyptostrobus Sinensis. A narrow fastigiate form, having a landscape value similar to the Lombardy poplar.

\section{DOGWOOD. Cornus}

Flowering. C. florida. This is the most showy native flowering tree. In the shadowy recesses of the forest the flowers appear as if floating in the air. As a lawn tree it rivals the Magnolias, flowering, like them, before the leaves appear. During the summer it maintains in all situations healthful dense foliage. With the sumach and woodbine it is the first to assume brilliant autumn colors. The clusters of large coral red berries attract the robins on their southward migration. The Dogwood is a tree to be extensively planted on the lawn in the rear of shrubbery, and in groves of large trees. Its ultimate height is about 20 feet, with an equal spread.

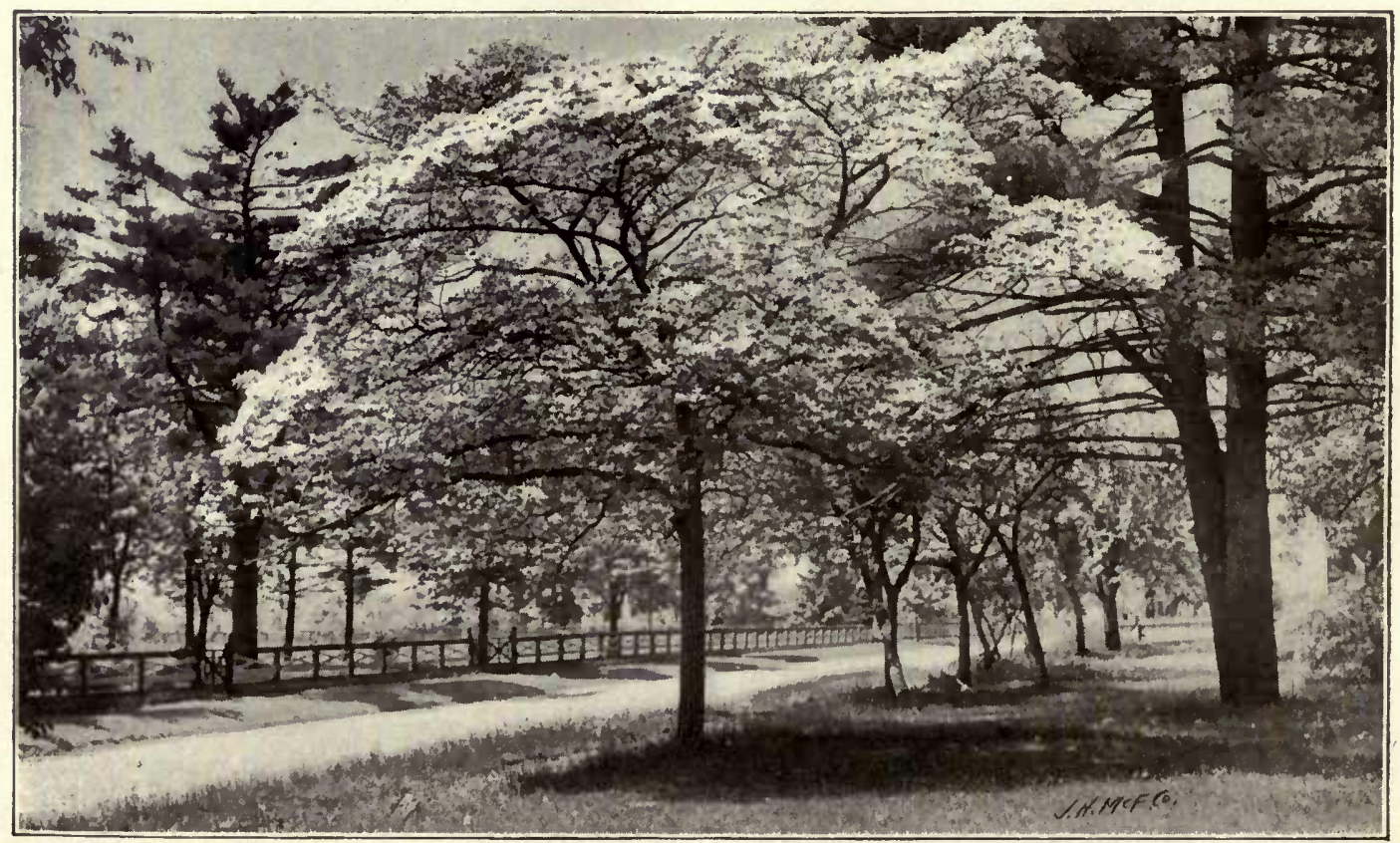

Dogwood at Hempstead, L. I., showing its value as a small street tree and for illuminating evergreen backgrounds. The horizontal disposition of foliage is a distinct feature in the landscape. 


\section{DOGWOOD, continued}

Red-flowering. Cormus florida, var. rubra. This beautiful and comparatively rare variety has bright pink flowers.

Japanese. C. Kousa. This differs from the flowerir $\mathrm{g}$ Dogwood in having long-pointed petals forming a star-shaped flower, and blooming about a month later, in June. It is a new and distinct tree worthy of planting. (See illustration.)

Variegated. C. macrophylla, var. variegata. A white-foliaged plant from Japan which maintains its color without beconing browned by the sun.

\section{ELM. Ulmus}

American. $U$. Americana. The Elm has contributed more to the landscape beauty of New England than any other tree. Its branches gracefully rise from the trunk with the lofty sweep of the gothic arch. At E st Hampton, Merrick, Glen Cove and many parts of the north shore the lofty height and wide curve of the branches attest that the soil and moisture supply make it perfectly at home. In some portions it fails to develop its fullest beauty, and should not, therefore, be extensively planted. In these regions mally of the oaks and Norway maples do thrive. The destructive elm-leaf beetle has been nearly exterminated by a fungous disease, thus illustrating the balance of nature.

Weeping. $U$. Americana, var. pendula. This has an open crown of wide arching branches. The tracery against the sky is graceful and cheerful, recommending it for grouping with other trees. It is a more beautiful change from the monotony of round-headed trees than the Lombardy poplar, and is much planted for that purpose. We offer trees 25 feet wide.

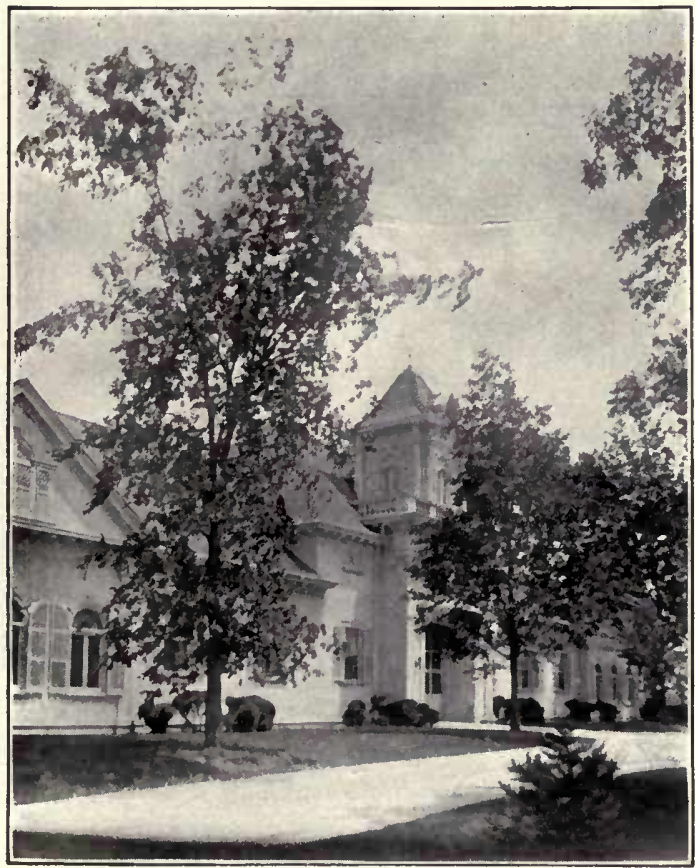

Elm and Sugar Maple by the stable at "Meudon," planted two years ago.

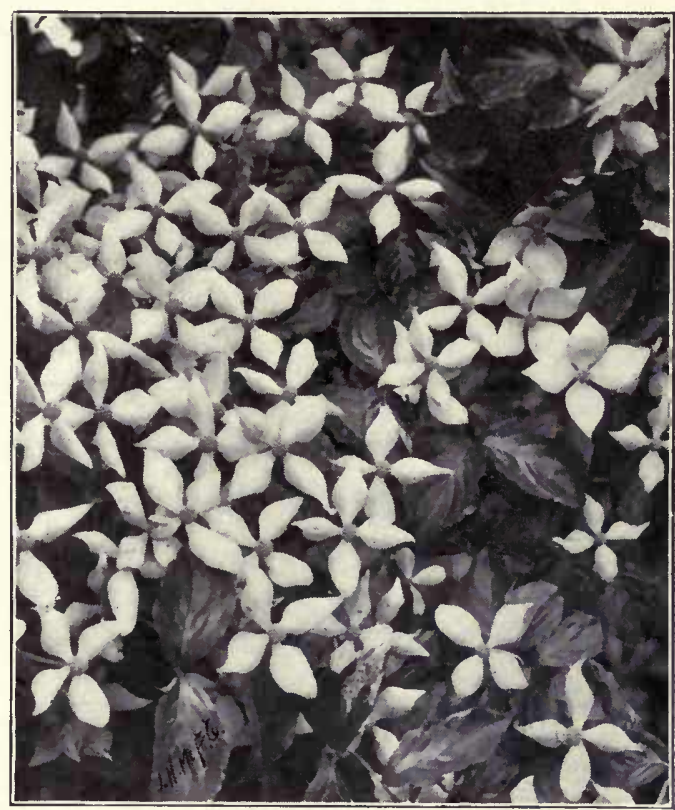

Japanese Dogwood. We offer an opportunity to get this very rare tree, and the most beautiful of its season.

\section{GINKGO}

G. biloba; syn., Salisburia adiantifolia. Maidenhair Tree. The Ginkgo stands out distinct from all other trees. The trunk, like its relatives in the pine family, is a gracefully tapering shaft. At a uniform ascending angle the widely spaced upper branches stand out against the sky. When old, its tall, massive trunk, its limbs in graceful curves, and its golden autumn foliage, make it a splendid and impressive object. It is a tree to plant for posterity, though it is rapid in growth. The Ginkgo's nearest relatives are fossils in the coal. It would have become extinct several centuries ago except for its preservation in the Japanese temple gardens, where trees a thousand years old are growing. Its insect and fungous enemies appear to have been left behind, for it has an entirely healthy growth even in cities.

\section{HICKORY. Hicoria; syn., Carya}

In this part of Long Island the Hickory as a tree standing alone in the field takes the place of the Elm in New England. To plant a tree to be valued by future generations is a worthy aim, well filled by the Hickory, White Oak or White Pine. They should be transplanted when small, and after becoming established will grow two feet per year.

Mockernut. H. tomentosa. A variety thriving on the poorest soils.

Shagbark. H. ovata; syn., H. alba. The best variety for fruit.

\section{HORNBEAM. Carpinus}

European. C. Betulus. This is a close relative of the beech, resembling it in bark and $f$ liage. In England it is used for hedges, and grows so strong and thick that a person can stand on its top. It is a healthy and handsome tree of compact rounded form. 


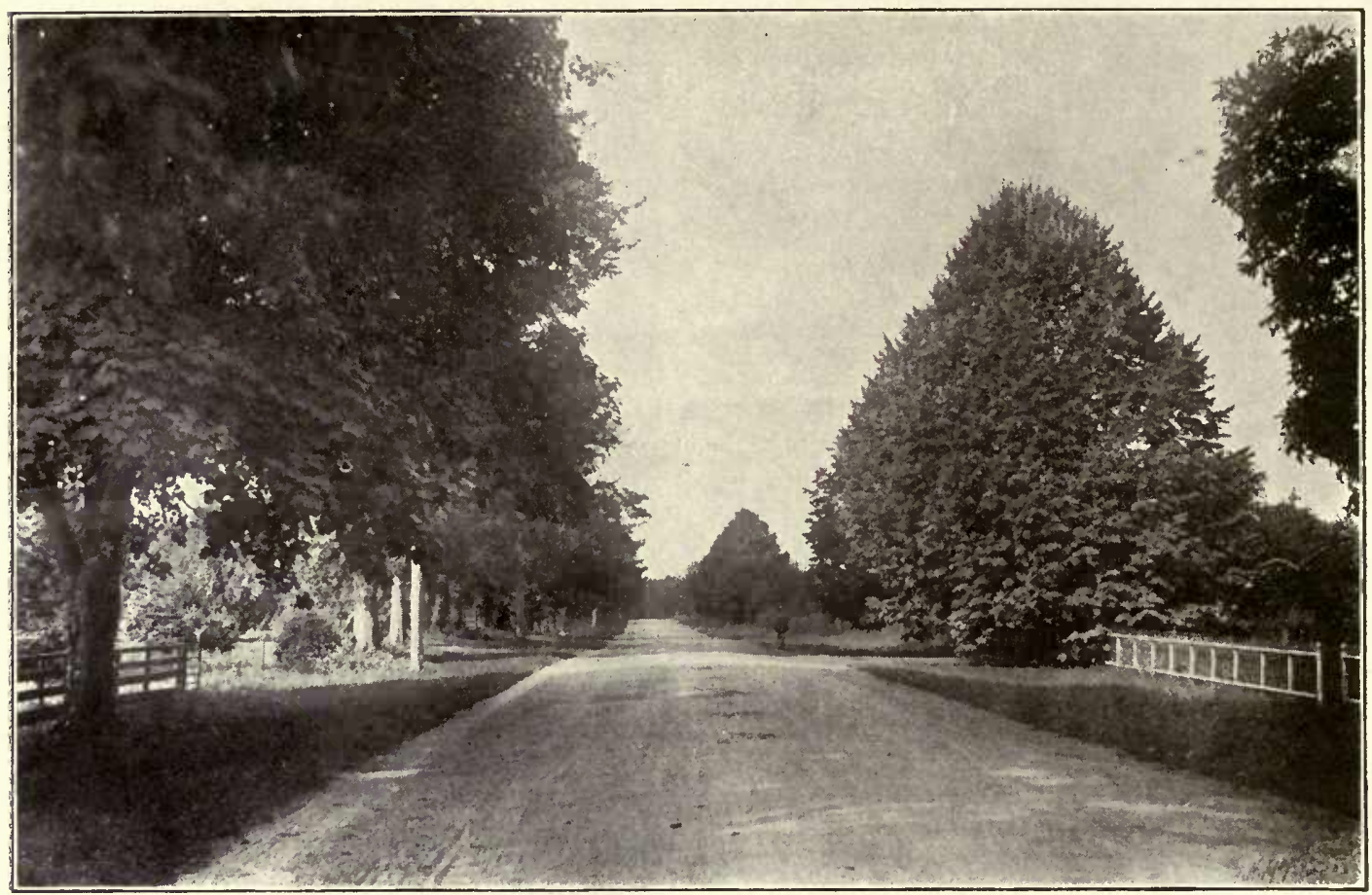

Jericho turnpike at Westbury Nurseries. On the right, a pair of Silver Lindens at the gate. On the left, Sycamore Maple and White Pine. Miles of pleasantly shaded Long Island roads have been planted from our Nurseries.

\section{HORSE - CHESTNUT}

\section{Esculus Hippocastanum}

The Horse-Chestnut and Buckeye are trees of medium to large size, thriving on rich and moist soil. Admiration is universally drawn to the HorseChestnut in early May, when it first bursts into flower, and the luxuriant foliage, so suddenly formed, casts a heavier shade than any other tree at the time. In favored localities it maintains good foliage, but in some parts of Long Island the leaves turn brown in late summer.

Red. AE. carnea; syn., AE. mubicunda. A smaller growing tree with bright red flowers.

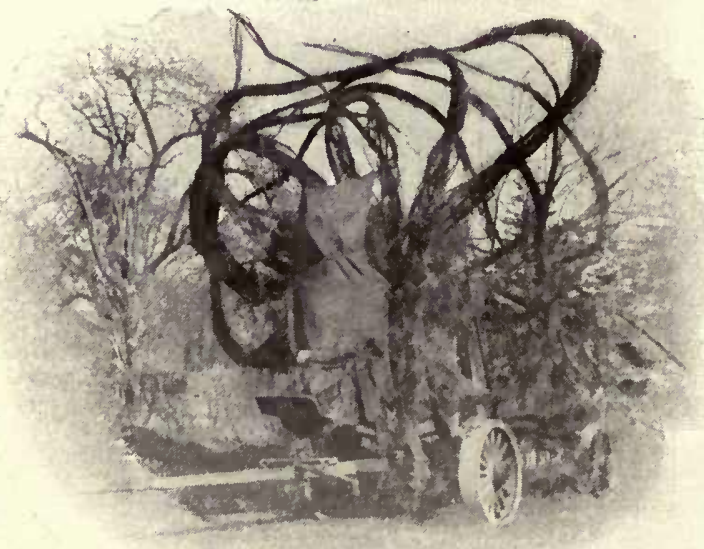

HORSE-CHESTNUT, continued

Dwarf. E. parviflora; syn., E. macrostachya. A most valuable shrub, flowering in July and maintaining healthy foliage. See under Shrubs.

\section{JUDAS. Cercis}

American. C. Canadensis. Red Bud. A small tree, blooming with the Dogwood. In early May, before the leaves appear, its branches are wreathed with rosy pink pea-shaped flowers.

Japanese. C. Chinensis. Usually a shrub, but in its native country a tree with brighter pink flowers. See under Shrubs.

\section{KENTUCKY COFFEE TREE Gymnocladus}

G. Canadensis. A large tree with divided leaves 2 feet long; requires deep, rich soil.

\section{KOELREUTERIA. Varnish Tree}

K. paniculata. A rare and beautiful Japanese tree with panicles of bright yellow flowers a foot long in midsummer.

\section{LARCH. Larix}

European. L. decidua; syn., L. Europaa. It is the first tree to come forth in its summer dress of a beautiful feathery light green, interspersed with tiny red cones, and makes a pleasing contrast to its darker green relatives, the pines and firs. 


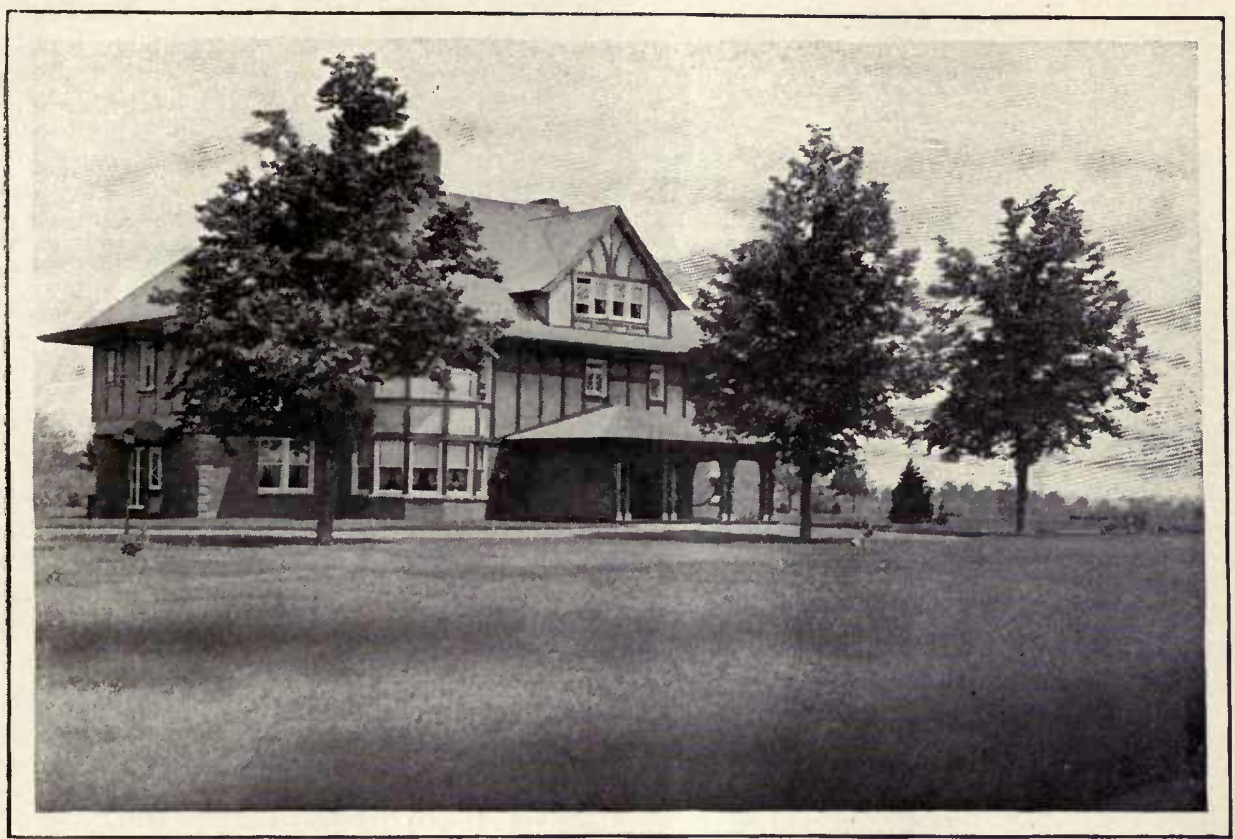

These English Lindens were started in our Nursery forty-five years ago, planted on Wheatley road, and ahout 1875 were moved to Garden City. When the hotel at that place was enlarged they were moved to the residence of Mr. William M. Baldwin, where they now stand.

\section{LINDEN. Tilia}

The Linden family comprises trees of the highest beauty, especially in the elliptical curves of their outlines, as all the species have an ovate, or egg-shaped form. The curves are so smooth and perfect as to excite general admiration. They all transplant readily and grow to a large size. For lawns and entrance drives they take first rank.

Silver. T. tomentosa; syn., T. argentea; syn., alba. White Linden. Justly considered one of the handsomest of trees. In symmetry of form and dignity of bearing it is unsurpassed. The upper sides of the leaves are dark green. The foliage remains in healthy condition through drought and other unfavorable conditions until late in autumn. (See illustration, preceding page.)

Spectabilis. T. tomentosa, var. spectabilis. A noble tree, resembling the above, except that the lower sides of the leaves are green.

Weeping Silver. T. petiolaris; syn., $T$. argentea, var. pendula. This distinct and beautiful species is a tall tree with just the tips of the twigs gracefully turning down. The lower branches arch to the ground, making a verdant tent. The foliage has the good qualities of the Silver Linden. We have specimens suitable for planting where a low branched tree is needed in the landscape. It grows to a height of 60 feet and will make a noble lawn specimen.

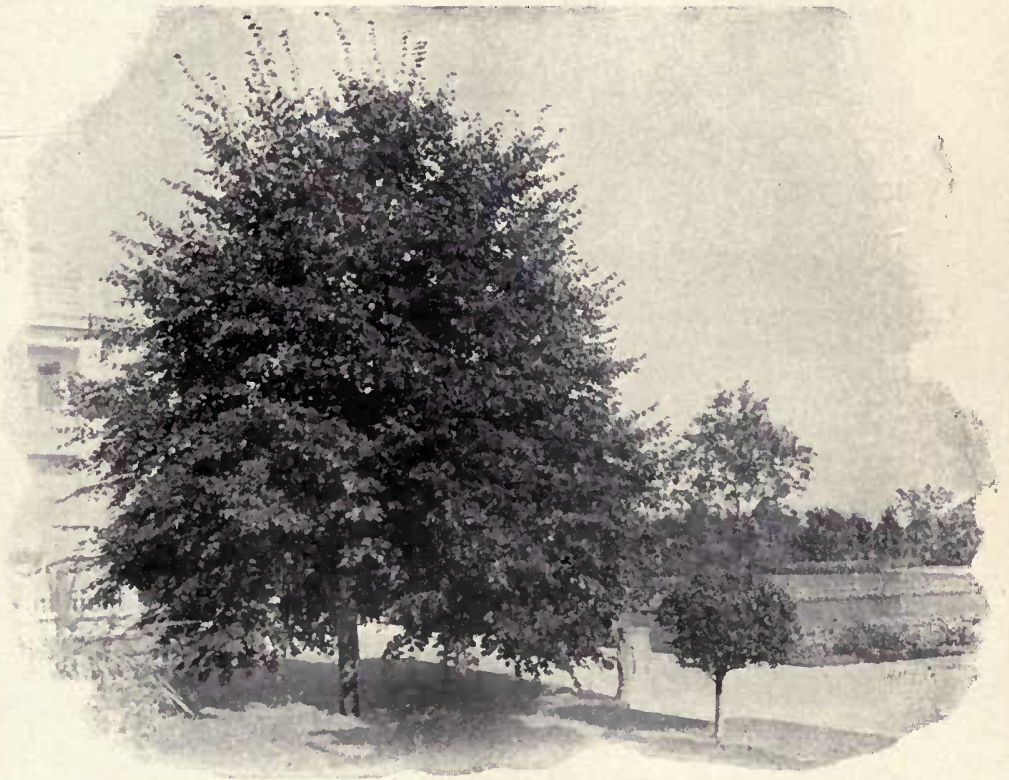

Small-leaved English Linden, from our Nursery, in the French formal garden at "Brookholt." S.andard Privet by the sun-dial, and large moved Maple
in the distance. 


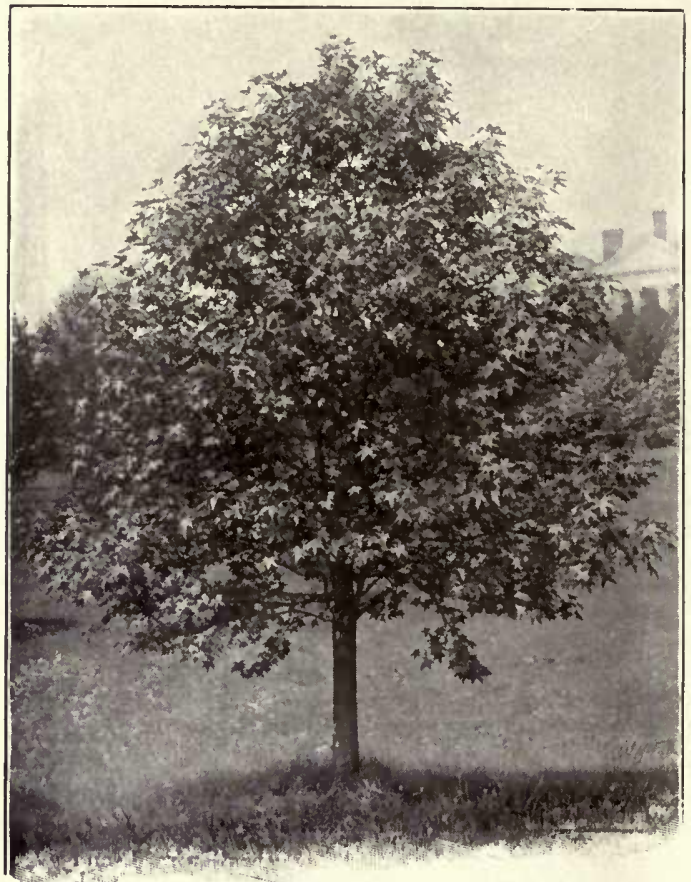

Liquidambar, or Sweet Gum. The shining star-shaped leaves are brilliant scarlet, bronze and orange in autumn.

\section{LINDEN, continued}

Small-leaved. T. ulmifolia; syn., microphylla. This and the Silver are the best of the family. The dense foliage of small leaves forms a compact and very symmetrical top. The foliage is maintained in good condition throughout the season. We recommend the tree highly for lawns, streets and entrance drives. (See illustration, on page 27.)

American. T. Americana. Basswood. A broadleaved tree requiring fertile, moist soil. The top is more open than that of the other Lindens.

European. T. Europac. A tall, ovate tree.

Broal-leaved. T. platyphylla. While this species is beautiful in spring, its foliage browns in midsummer.

\section{LIQUIDAMBAR. Slweet Gum}

I. styraciflua. Bilsted. A noble forest tree, native to Long Island, and thriving in various situations. In autumn it exceeds other trees in the variety and depth of its coloring-red, gold, purple and bronze appearing on the same leaf. The leaves are star-shaped, glossy green and healthy. In form and rate of growth it resembles the lindens and sugar maple. Transplants in spring only.

\section{LOCUST}

Yellow. Robinia Pseudacacia. Millions of Locust trees have been planted on Long Island in the past two centuries for timber, and especially for "tree nails," or spikes for wooden ships. The legend is that it was introduced from Virginia by Captain John Sands, of Sand's Point, Port Washington. It thrives over most of the island. Having the ability to gather nitrogen from the air, it grows
YELLOW LOCUST, continued

vigorously in soil too sterile for other trees, in twenty years being ready to cut for posts. The foliage and roots permit grass and shrubs to grow freely with it.

Honey. Gleditschia triacanthos. Three-thorned Acacia. The Honey Locust quickly attains broad and noble proportions even in sterile soil on the ocean side. The feathery foliage is graceful and healthy.

\section{MAGNOLIA}

The Magnolia may be divided into two sections; the trees flowering after the leaves appear and the shrubs flowering before, described on page 50. Magnolias have heretofore been limited in planting to one or two specimens on al lawis, because of their rarity in the nurseries and the difficulty of successfully transplanting them, especially if they are shipped a distance. To overcome this we have commenced raising them in large quantities from acclimated seed, and they can now be used, as they deserve, for general planting.

Umbrella. M. tripetala. A low and broad-spreading tree of tropical appearance, having leaves I $1 / 2$ feet long. The white flowers are 8 to Io inches across, and produced in June. Though one of the most showy and beautiful trees when in bloom, it arouses equal admiration when in fruit in late summer. 'The fruits are crimson, cylindrical, 6 inches long and 2 inches in diameter, from which scarlet seeds hang out on silken threads to attract the birds. We recommend it highly for lawn planting.

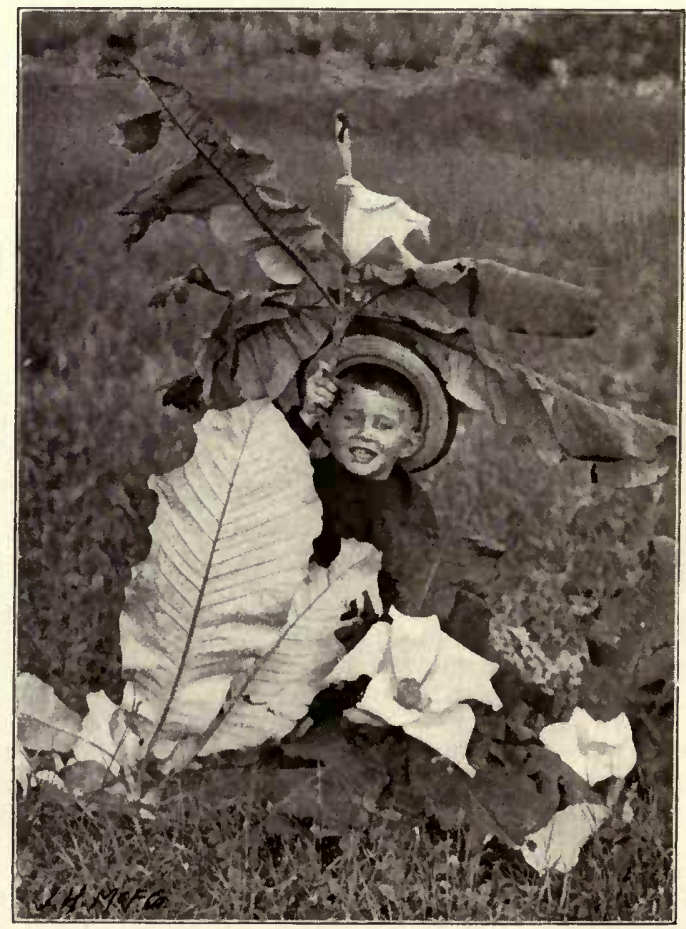

Large-leaf Magiulia, M. macrophylla. (See page 29.) 
MAGNOLIA, continued

Large-leaved. MI. macrophylla. This tiee has the largest flowers of any plant of the temperate zone; they are like alabaster vases; the petals are of graceful form and firm in texture; when fully open they are a foot across. The leaves are proportionately large, being 2 feet long. It is one of the rarest ornamental trees. (See illustration on preceding page.)

Cucumber.. . acuminata. The Cucumber Tree is pyramidal in form, of large size, resembling its relative, the tulip tree, in size, form and requirements. The flowers are not especially conspicuous, being greenish white and partly hidden by the foliage.

Sweet Bay. Mr. glanca. The Sweet Bay Magnolia is most commonly known as the Magnolia flower sold on the city streets in June. The exceedingly fragrant flowers are creamy white, cups 3 inches wide, with leaves about the same length. It forms a small tree or shrub. Native of Long Island.

\section{MAPLE. Acer}

As a result of their many good qualities, the Maples are the most extensively planted of all trees. A comparison of the various species will show the wide range of their usefulness. 'The Sugar Maple is a native of New England and westward, but rarely of Long Island. Along the north shore and on the hills it frequently grows well, especially where there is a deep loam soil, or clay or hard-pan subsoil. On the plains region, with its subsoil of sand and gravel, the Sugar Maple, the Elm, the Kentucky Coffee Tree, and some others do not reach the perfection of old age and feel at home. Although it has had opportunity for thousands of years, the Sugar Maple has not established itself, and seedlings do not spring up around it. The foliage sometimes turns brown in summer, while the Norway Maple foliage does not. The Norway Maple does thrive vigorously in this region, reaching its highest development, and the young seedlings spring up freely under old trees.

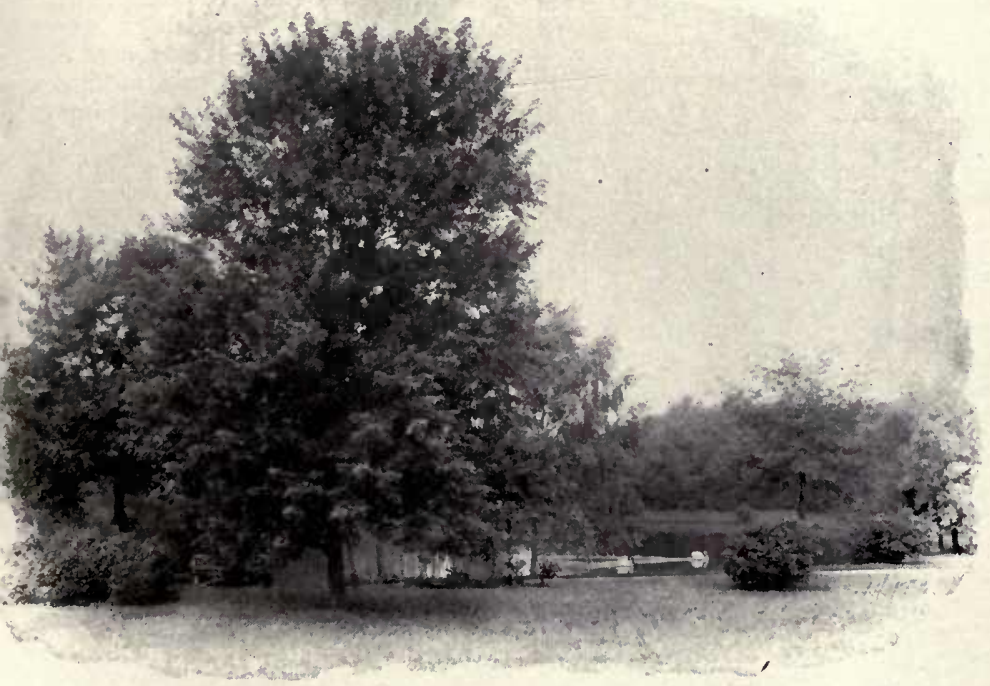

Artificial lake at "Brookholt," the residence of Hon. O. H. P. Belmont. To shade the dock and rustic seat these lare Maples were moved from our Nursers, as well as the screen of large evergreens bordering the public road. Photographed three years after planting.
The Red, or Scarlet, Maple is native to all parts of the island, both along the streams and on the upland. Its nearest relative, the Silver Maple, is native to rich river bottoms in the Middle States. It is so rapid in growth that its branches have not the strength of other Maples.

Norway. A. platanoides. The Norway Maple is the best all-round shade tree for Long Island. Its foliage is retained in good health until late in autumn, when it turns a clear yellow. It is a tree which may be depended upon to live when transplanted, and grow and thrive on poor and dry soil, growing faster, of course, when well fed. In form the head is a sphere, or in old trees a hemisphere, with broad spreading branches. For street planting our trees are trained with high heads to 


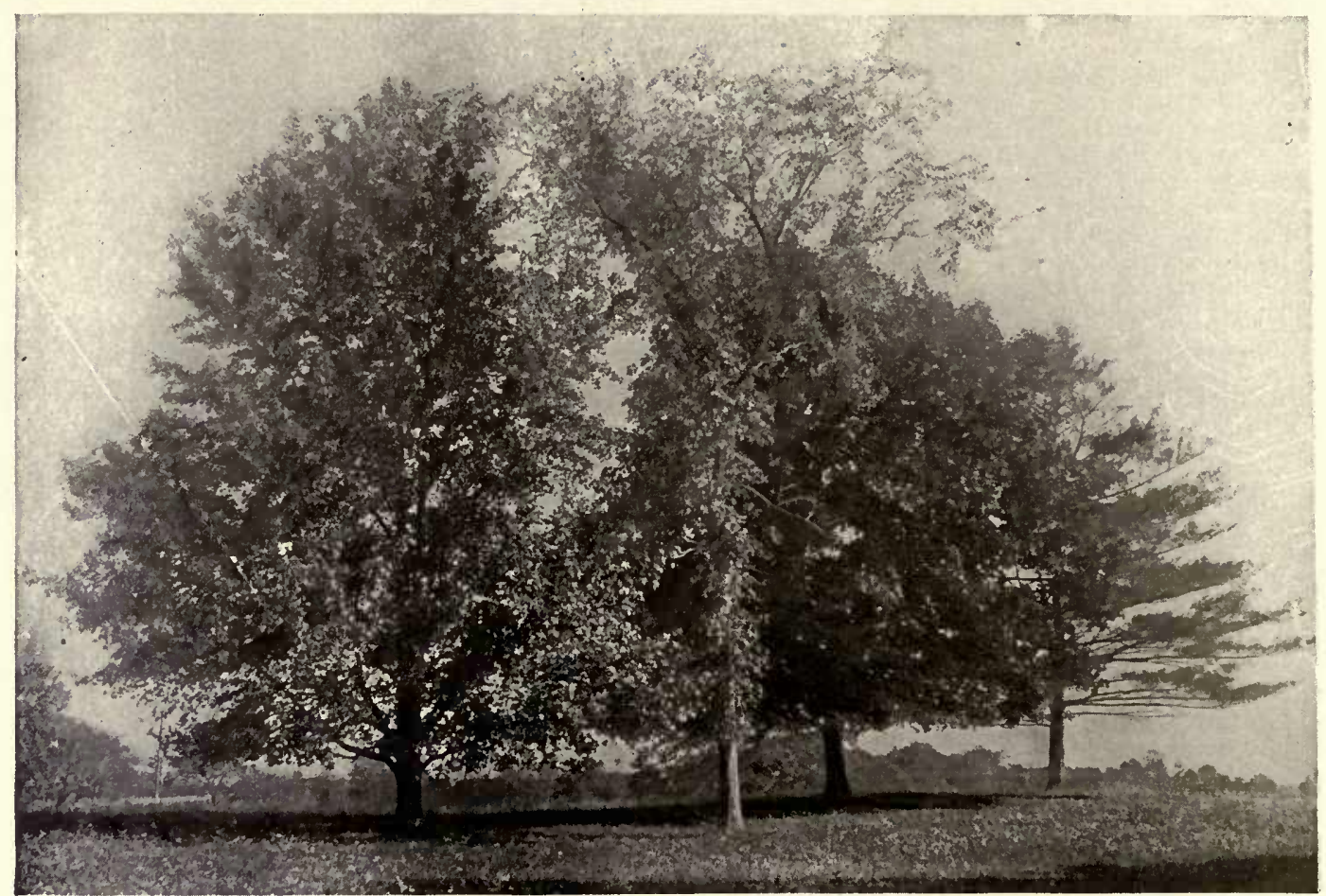

\section{NORWAY MAPLE, continued}

clear wagon tops, the lower branches being at Io or I2 feet. The leader, or trunk, is continued up through the top, so that they may be pruned still higher without disfiguring the tree or causing large wounds. Our stock is the largest in size and of the best quality in existence. Where
NORWAY MAPLE, continued

the problem is to furnish foliage immediately for shade, ornament or screens, these large-sized Norway Maples, I5 to 22 feet high and 6 to I 2 feet spread of branches and roots, will give best satisfaction. In the ordinary sizes of 8 to I 6 feet, an $1 \mathrm{I} 1 / 2$ to $2 \frac{1}{2}$ inches in diameter, our stock is in large quantity and at low prices, and worthy the attention of extensive planters for groves, drives, roadsides and streets. For the development of real estate for sale as building lots the Norway Maple is the best tree. A few well-established trees planted on the lots enhance the attractiveness and value of the property.

Schwedler's Purple Norway. $A$. platanoides, var. Schuedleri. With all the vigor of the Norway Maple, the purple variety has the foliage effect of the Purple Beech, the leaves being bright red during spring, and in early summer changing to dark green.

Reitenbach's Purple Norway. $A$. platanoides, var. Reitenbachi. Unlike the last, it is dark bloodred in late summer.

Sugar, Rock or Hard Maple. $A$. sacchanum; syn., A. saccharinum. The form of the Sugar Maple is upright and ovate and not as broad as the other Maples. The autumn color is yellow and red. 


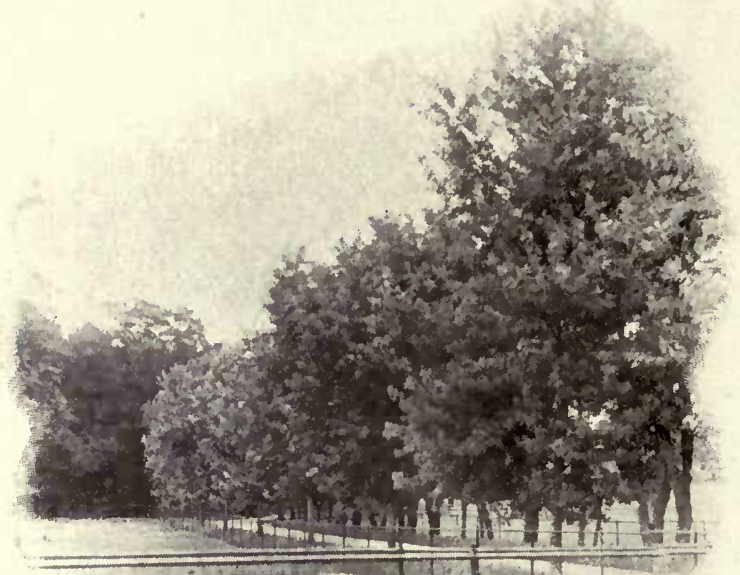

$x^{2}$

A side entrance at Castlegould. Large Maples moved from the nurseries have grown 4 feet in the first fifteen months. An existing hedge-row of Wild Cherry on one side.

MULBERRIES, continued

Russian. M. alba, var. Tatarica. This is a bushytopped small tree of dense foliage, suited to large shrubberies. It was introduced into the
RUSSIAN MULBERRY, continued

western states by Russian Menmonites, and recently the following variety was found:

Weeping. $M$. alba, var. Tatarica pendula. Of the several unibrella-shaped trees, as Kilmarnock Willow, Camperdown Eln, Weeping Ash, etc., this is much the best; far exceeding them in this climate, in vigor and healthfulness; growing 7 feet per year. The fruit is of little value. The usual form is grafted on a stem 4 feet ligh, when it weeps straight to the ground. We have devised the following new methods of training it, and offer suitable plants for the purpose :

As a verdant tent or summer-house we have them in various heights, from 5 to 8 feet. (See illustration.) A pair of trees will form a garden arch, or a row of them will make a beautiful pergola, no posts being necessary after they are established. It may also be trained on a trellis, arbor or wall, as are grape-vines or espalier fruit trees in European gardens. When trained to a stake or pipe, to a height of 15 or 20 feet, the long and graceful sprays fall like fountain jets. As a shrub, it heaps up a mass of arching branches, perhaps 4 feet high and twice as wide, being suitable both for masses in the shrubhery and as a specimen standing on the lawn. On exposed and windy places it is especially valuable. To those wishing a new garden feature, which is quickly complete, these forms are highly recommended.

For covering steep banks it has the babit of Forsythia suspensa.

\section{OAK. Quercus}

'I'he Oak has long had a hold on the affections of the people through its individuality and its almost human characteristics of dignity and nobility, which are marked both in old and young trees. The opinion that they are of slow growth is due to the fact that they can patiently endure on a poor and dry soil. In our nursery, and when planted on lawns, they frequently grow 4 feet per year.

Oaks should be extensively planted along streets, entrance drives and on lawns. The Brooklyn TreePlanting Society has planted many of our Oaks on: the streets and found them to thrive despite the unfavorable conditions of pavements, dust, smoke and insects.

Where a broad shade is desired quickly and Oaks cannot be procured of sufficient size, extrasized Maples, as describea on page $3 \mathrm{I}$, may be planted between the Oaks and later taken out with the tree-mover.

The Oaks have a reputation of being difficult to transplant. The new roots start slower than other trees, because of the slower circulation of the sap, the crude sap having first to go up to the leaves to be digested,

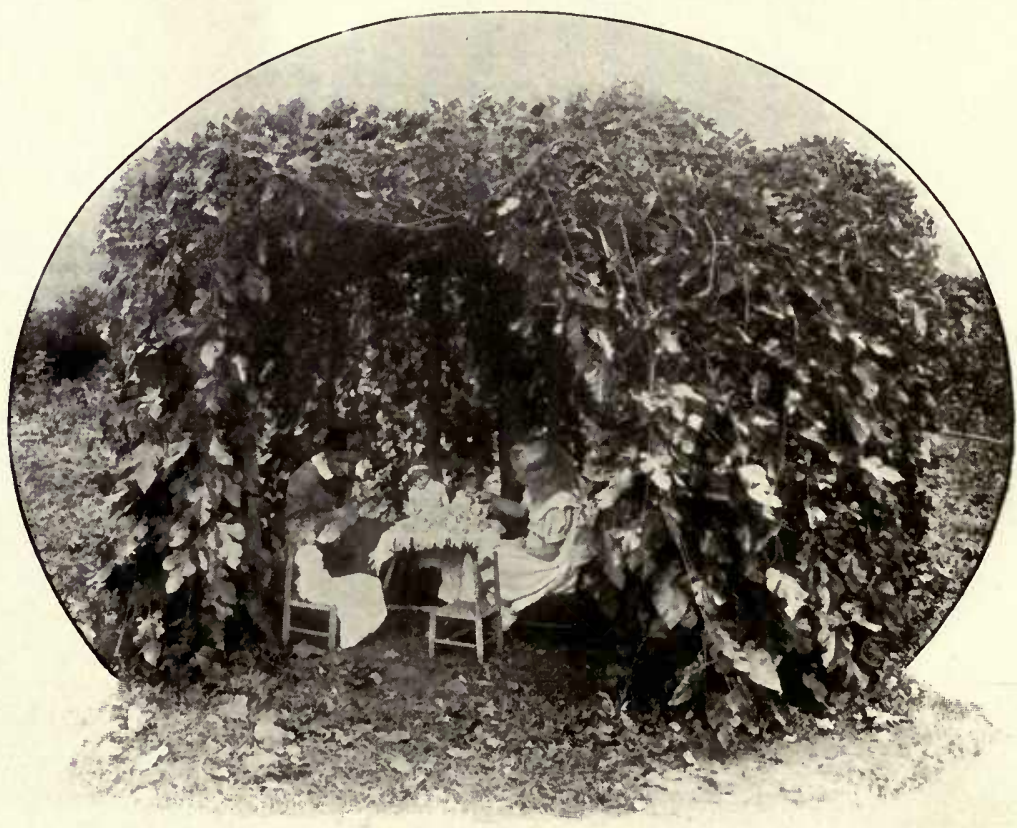

Weeping Mulberry trained for a child's summer-house. One of a row in our nursery. 


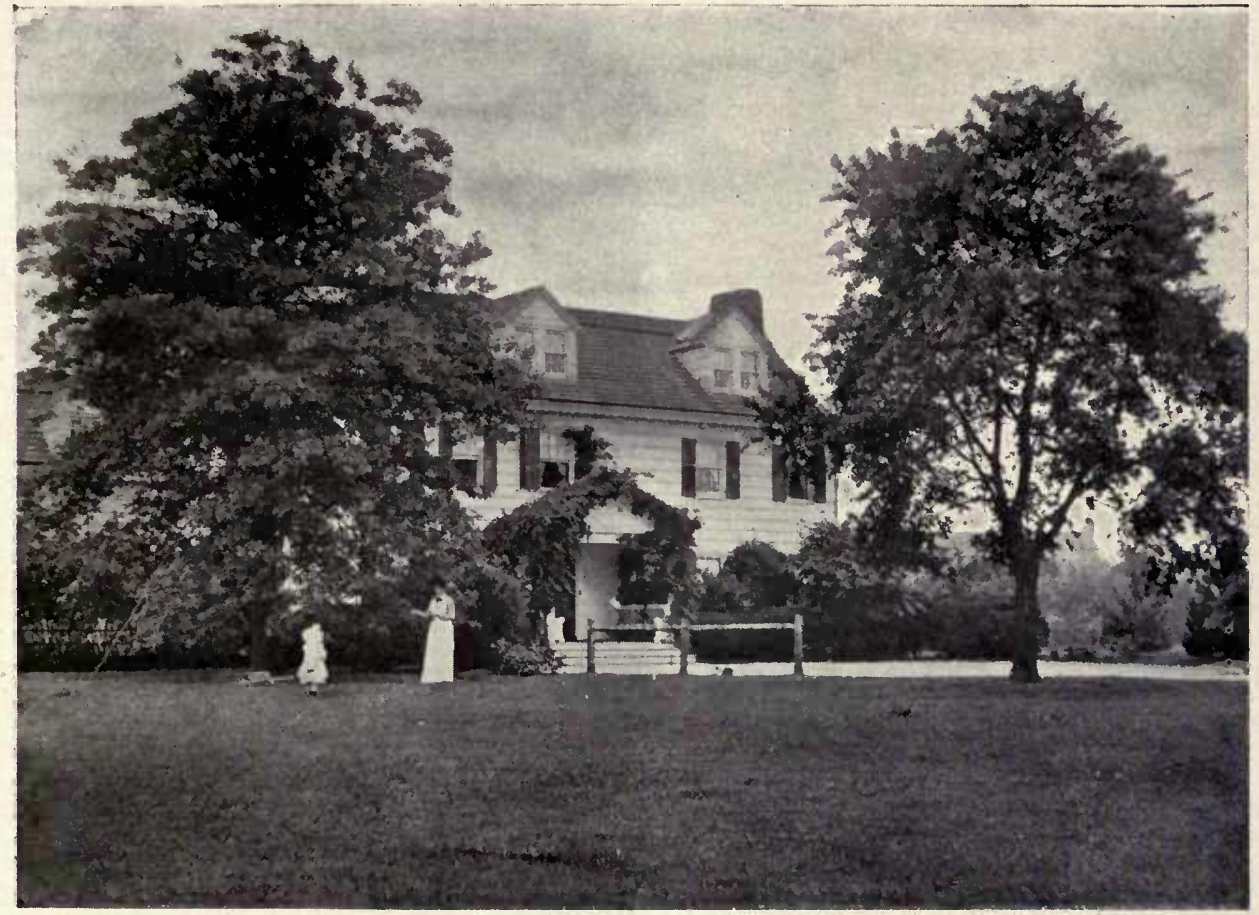

Residence of Mr. John L. Lawrence, Lawrence, L. I. This new seaside lawn, planted with low-spreading Pin Oak, Wild Cherry, and old Dwarf Boxwood, has immediately the charm and repose of a half century's growth. Photographed four years after planting.

\section{OAK, continued}

and then return to make new roots. These new roots, just getting to work, may not supply the demands for moisture in summer, and the tree may die. Our Oaks have the roots properly trained for transplanting, and are carefully dug. The pruning should reduce the buds to 15 or 25 per cent of the original number, leaving some large buds at the end of each branch. Wrapping the trunk with straw, and mulching the ground, help to establish the tree. Understanding these principles, no more trouble need be expected with Oaks than with other trees.

Pin. Q. patustris. The Pin Oak is a thickly branched tree of upright ovate form and graceful habit. It is the most popular and most generally planted of the Oaks. It may be identified by its habit of drooping its long, slender lower branches at a uniform ancle. The small glossy leaves are bright red in autumn. As an avenue or broad-spreading lawn tree it is unsurpassed. Trees 5o feet high transplant readily and grow well. Besides the usual sizes we offer many Pin Oaks, 20 to 30 feet, and 30 to 40 feet high, as illustrated below, and strongly recomniend their use. They give a dignity and completeness attainable witl few other trees. Prices, including delivery on the treemover and planting, on application. The roots are so trained that they may be safely shipped by rail.

Scarlet. Q. coccinea. This species is so named from its bright scarlet autumn color. The tree resembles the Pin Oak in foliage and form, except that the lower limbs are horizontal or ascending. We offer specimens to to I 5 feet high.

Red. Q. rubra. The Red Oak is a large and noble tree, with strong, wide-reaching arms. The large leaves in autumn are a dull crimson.

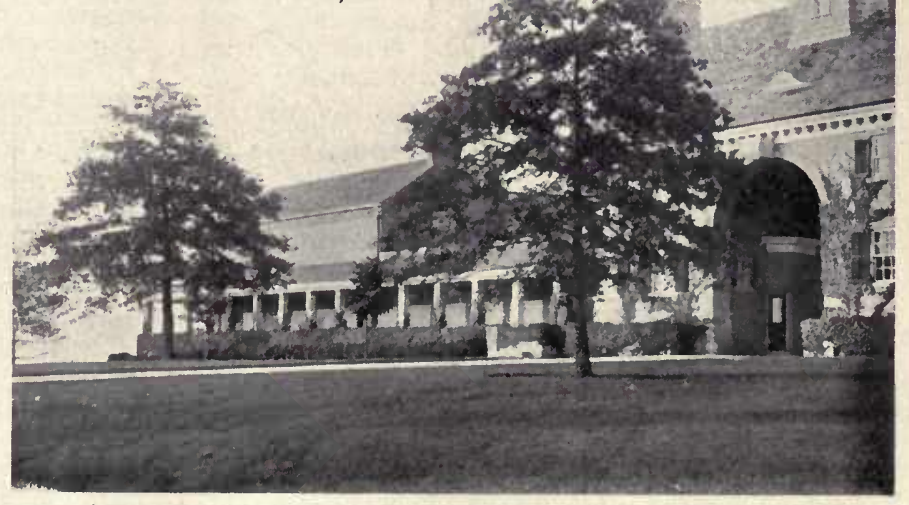

Pair of Pin Oaks, and hedge of old Boxwood, 4 to 7 feet high, moved with the tree-mover for Mr. E. D. Morgan, Wheatley Hills, L. I. 
OAK, continued

willow. $Q$. Phellos. The willow-like leaves are a half-inch wide. It is a close pyramid of slender gray twigs.

White. $Q$. alba. The White Oak is the most majestic of all native trees.

Swamp White. $Q$. bicolor. This forms a tall tree with light gray flaky bark.

Mossy Cup, or Burr. Q. macrocarpa. A lofty tree, rugged, rough and strong. The twigs are ridged with cork, like the liquidambar. We offer trees Io to 23 feet.

English, or Royal. $Q$. pedunculata; syn., $Q$. Robur. This is the Oak of the English parks. It is a noble broad-spreading tree with powerful horizontal branches, and closely resembles our White Oak. In this region it grows rapidly; sometimes 4 feet per year.

Pyramidal English. Q. pedunculata, var. fastigiata. It is a narrow columnar tree like the Lombardy Poplar.

Golden English. $Q$, pedunculata, var. Concordia. The foliage is bright yellow in spring.

Besides the above list, we have specimens of many rare species of Oak.

\section{PAULOWNIA. Empress Tree}

P. imperialis. In early May this tree sends out a pleasant perfume, and it is rather surprising to find the cause in flowers so nearly like the sky in color as not to be noticed at first sight. The flowers are trumpet-shaped, 3 inches long, borne in panicles a foot in length. The large tall tree resembles its relative the catalpa, but it is more open and irregular. For tropical gardening, the stem is cut to the ground, and annually shoots up ro feet with leaves 2 feet wide.

\section{PEACH. Prunus}

Double-flowering. P. Persica, var. camellicflora plena. These are clouds of beautiful color, being masses of double rose-like flowers of white, pink or crimson. They are small, short-lived trees, benefited by close pruning and fertilizing it with wood ashes.

\section{PEPPERIDGE. Nyssa}

N. sylvatica. Sour Gum. This is a tree native to wet ground, remarkable for its horizontal branches, shining leaves and flaming scarlet autumn color. It transplants with difficulty.

\section{PERSIMMON. Diospyros}

D. Virginiana. It is not generally known that this fruit tree of the South is native here, forming a round-headed tree of healthy dark and glossy foliage.

\section{PHELLODENDRON}

\section{Chinese Cork Tree}

P. Amurense. Like many plants from the Amoor Valley in China, finding the climate similar, this thrives and grows rapidly here. It resists drought and is free from insect attacks. The foliage and form resemble the black walnut.

\section{PLANE TREE. Platanus}

P. orientalis. Oriental Plane, or Sycamore. The Plane is a vigorous and rapid-growing tree of the largest size. The wide thick leaves withstand salt spray. In winter the tree is ornamental because of the light-colored bark. It has been famous and largely planted since the days of the ancient Greeks. It is a good street tree and does not suffer from the fungous disease which kills the twigs of the native Buttonball, or American Plane. An excellent city tree.

\section{PLUM. Prunus}

Purple. $P$. cerasifera. var. alropurpurea; syn., $P$. Pissardii. The Purple Plum has especially bright red foliage in midsummer and purple in the autumn.

\section{POPLAR. Populus}

The Poplars belong to the Willow family. A prominent characteristic of the family is quickness of growth, some members exceeding all other trees of temperate regions. The wood is soft and light. They are strong feeders and repay added fertility and moisture with luxuriant growth.

Carolina. P. deltoides, var. Carolinensis. This is the most commonly planted Poplar, quickly forming a tall tree. Where quick results for a few years are wanted it answers well. Many thousands have been planted on real estate subdivisions, but after a dozen years only a small proportion remain in good condition. On heavier soil in the Prairie States, and along the streams, it makes a large old tree. It is benefited by fertilizing and bi-annually cutting back, which helps it to overcome its fungous enemies.

Lombardy. P. nigra, var. Italica; syn., P. fastigiala; syn., $P$. dilatata. The Lombardy Poplar is an exclamation point in the landscape. Its vertical column of foliage strikes a new note in the tranquillity of ordinary scenery, and is a pleasing break in the sky-line of round-headed trees. It is sometimes used for vistas and screens. For immediate screens, tall trees of more permanent species, as maples, on page 29, are preferable. In France, long avenues of them are characteristic.

Japanese. $P$. suaveolens. This is by far the best Poplar for this climate, as may be expected from its origin. The foliage comes out earlier in spring than other trees, and is a beautiful shade of light green, maintained throughout the season. It is free from the fungous attacks which frequently cause the Carolina Poplar to drop its foliage in late summer. It roots deeper than other Poplars, therefore resists drought better.

Prof. Sargent, director of Arnold Arboretum, Harvard, writes us: "I believe your specimen to be the northern China and northern Japan, $P$. suaveolens, which I see in this country for the first time. I met with this tree in northern Japan, where it grows to a very large size, but was unable to introduce it into cultivation." As far as we know, this is the only nursery offering it. For transplanting on tree-mover, we offer trees 30 to 40 feet high, as beautiful and symmetrical as the tulip tree. 


\section{SASSAFRAS}

S. officinale. The beauty of the Sassafras as a lawn tree is not appreciated because it is usually seen crowded in a hedgerow. It thrives on light soil and keeps good foliage.

\section{SOPHORA \\ Japan Pagoda Tree}

S. Japonicus. This is a roundheaded tree of the locust family, with cream-colored flowers in midsumner.

\section{STYRAX}

S. Japonica. Too high praise cannot be accorded the delicate and chaste beauty of this new acquisition. It is so neat and dainty in its general habit that it is worthy of planting even without the myriads of silver bells or snowdrops, gracefully suspended from its branches in early summer. When young it is a pyramidal shrub, broad at the base, with pleasing foliage. Wortliy of being placed singly on the lawn, and as much honor accorded it as to the Magnolia. The flowers very much resemble those of the Silver Bell tree, illustrated on this page.

\section{SILVER BELL, or SNOWDROP TREE}

\section{Halesia}

H. tetraptera ; syn., Mohrodendron tetraptera. A small tree or large shrub decorated in May with hanging bells of pure white flowers.

\section{THORN (Hawthorn) Crataegus}

This family is most widely known through the hedges of England. They are all small, thick-topped, thorny trees bearing clusters of flowers in May, and red haws or miniature apples in autumn. They group harmoniously with both trees and shrubs. The English Thorn is so variable in its success here that we do not recommend its general cultivation.

Paul's Double Scarlet. C. Monogyna, var. Pauli. In May a tree of this variety looks like a mass of fire, and no plant exceeds its brilliancy of color.

Cockspur. C. Crus-galli. This is to be found on the edges of the salt meadows and on the Hempstead Plains, where it is too windy for other trees. The horizontally arranged branclies of shiny foliage give a distinct element to a group of trees or shrubs.

\section{TULIP TREE \\ Liriodendron}

L. Tulipifera. White Wood. No tree native of Long Island is more worthy of praise, as it ranks with the White Pine and White Oak, among our noblest trees. The trunk is as straight and graceful as a Grecian column. The beauty and symmetry of its ovate top is worthy of admiration. The flowers are yellow tulips. It rapidly becomes a large tree. It should be transplanted in spring only.

Pyramidal. L. Tulipifera, var. pyramidale. With all the healthfulness of the species, this variety promises to fill the same place in the landscape as Lombardy Poplar.

\section{YELLOW-WOOD Cladrastis}

C. tinctoria ; syn., Virgilea Iutea. This neat clean tree has long racemes of white flowers like the wistaria. 'The smooth gray bark resembles the beeches.

\section{WILLOW. Salix}

The Willow family is characterized by quick growth, ability to grow on upland and where too wet for many other trees, and ease of transplanting. They have generally narrow leaves. For forming shelterbelts near the sea, they should be planted thickly with poplars, privet and other species recommended for the purpose, in groups i 5 to 50 feet wide, 5 to I 2 feet apart. In the lee of such shelter-belts most other species thriving in this latitude may be grown, as well as Pines, Firs and Spruces, thus making an all-the-year-round shelter. The thickly matted roots hold streambanks and shores.

Babylonian Weeping. S. Babylonica. In old trees the wide top of gnarled branches supports a soft veil of foliage dipping to the water.

Salamon's. S. Babylonica, var. Salamonii. The most rapid-growing tree where it finds a supply of moisture and fertility. It is more upriglit than the Babylonian, and makes a handsone tree, with the tips of the branches droopins:

Yellow. S. vitcllina. The Yellow IVillow, sometimes called White Willow, is a broad-spreading tree with no weeping branches. It quickly becontes a tree 2 or 3 feet in diameter. 
Deciduous Trees

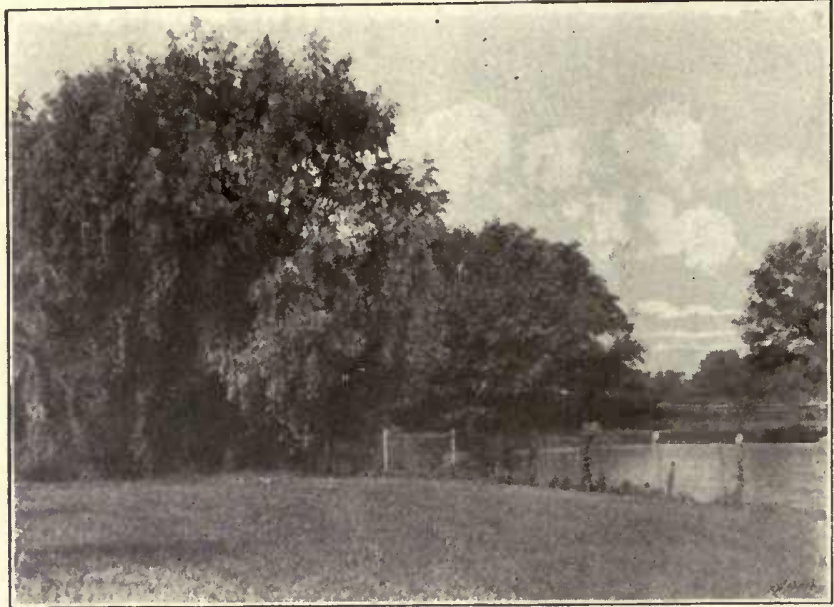

Salamon's Weeping Willow planted as a snall tree at Westbury Pond. Photograph seven years later.

WILLOW, conlinued

Golden. S. vitellina, var. aurea. It grows to a large tree, or nuy be kept as a shrub by cutting back. With the Red-twig Dogwood its golden bark forms a beautiful contrast-a cheerful and harmonious touch in the winter landscape.

Salmon-barked. S. vitellina, var. Britzensis. A unique tree with brilliant salmon-red bark in winter.

Royal. S. alba; syn., S. regalis. The silky down on the leaves gives the tree a white or silvery gray appearance. It is of value for contrast in groups of shrubs, especially at the seaside.

\section{ISAAC HICKS \& SON}

WILLOW, continued

Laurel-Leaf, or Bay-Leaf. S. pentandra; syn., S. laurifolia. It differs markedly from other Willows in having broad leaves which exceed all others in glossiness, and appear as if polished and varnished. It is an upright-growing, round-headed tree, or it may be grown in the form of a shrub, in which case it closely resembles the privet. Being, however, more rapid in growth, it can be used instead of privet for tall hedges and screens, especially near the shore. We have specimens which have been trained in the form of the bay tree.

\section{WALNUT. Juglans}

See, also, Nut Trees

Black. J. nigra. The Black Walnut is one of the largest trees in this region, where the strength and ruggedness of its far-reaching branches render it worthy of admiration. It needs ample room for its aggressive roots, as other plants do not thrive near it. 'The nuts are of good quality.

White (Butternut). $J$. cinerea. The tree is smaller than the Black Walnut.

English. J. regia. It is not generally known that Long Island contains many old specimens of the English or Persian Walnut. Although tender while young, it may be readily established.

Japanese. J.cordiformis. This is a rapid-growing tree resembling the Butterutut.

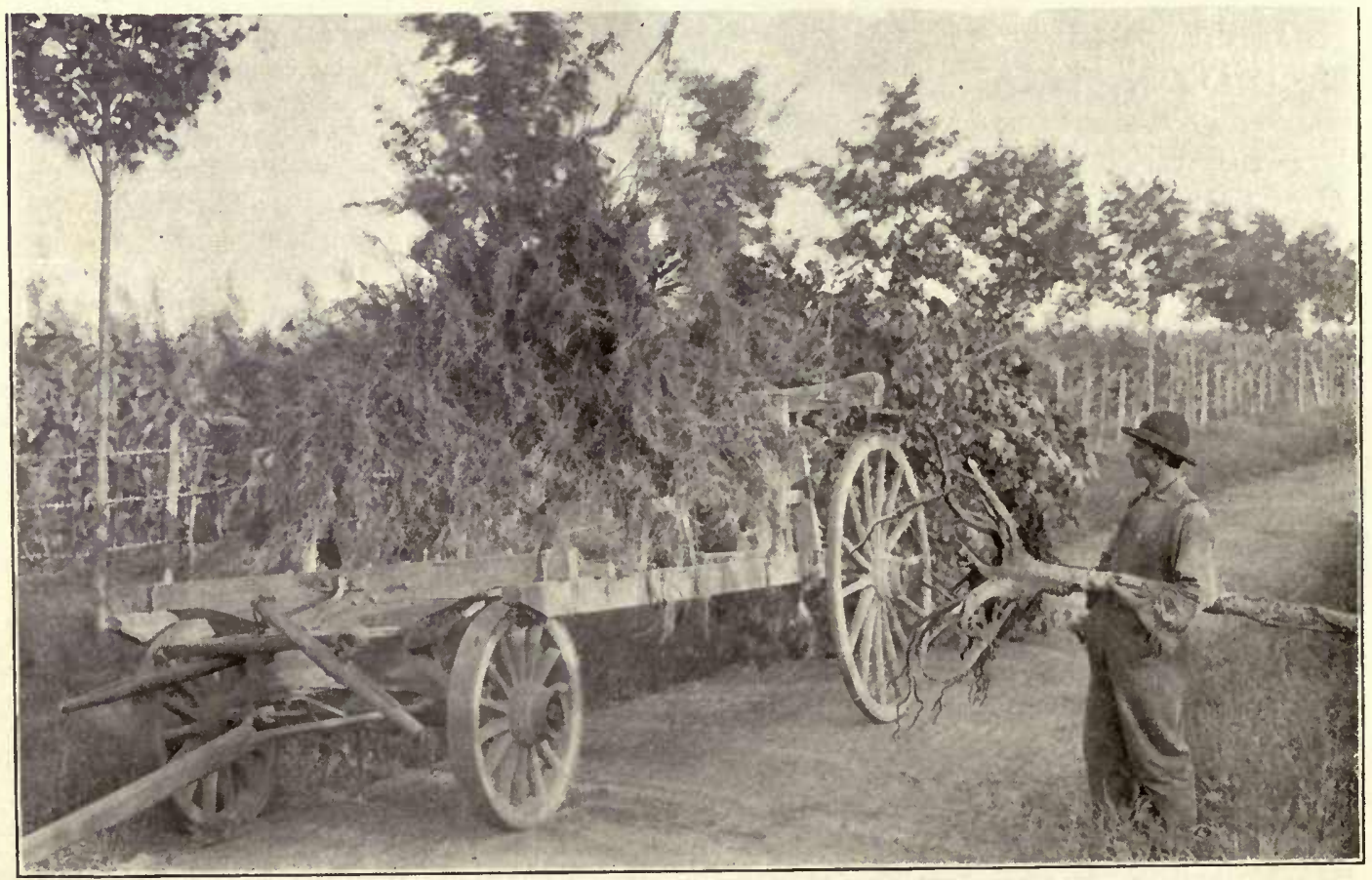

The 1 ree on the truck shows the abundant feeding-roots grown in our soil by our ront-lraining methods, and dug hv us, and makes a forceful argument in favor of our principles when compared wilh the tree held by the man on the right, which is of the same age and as sometimes grown and dug. 


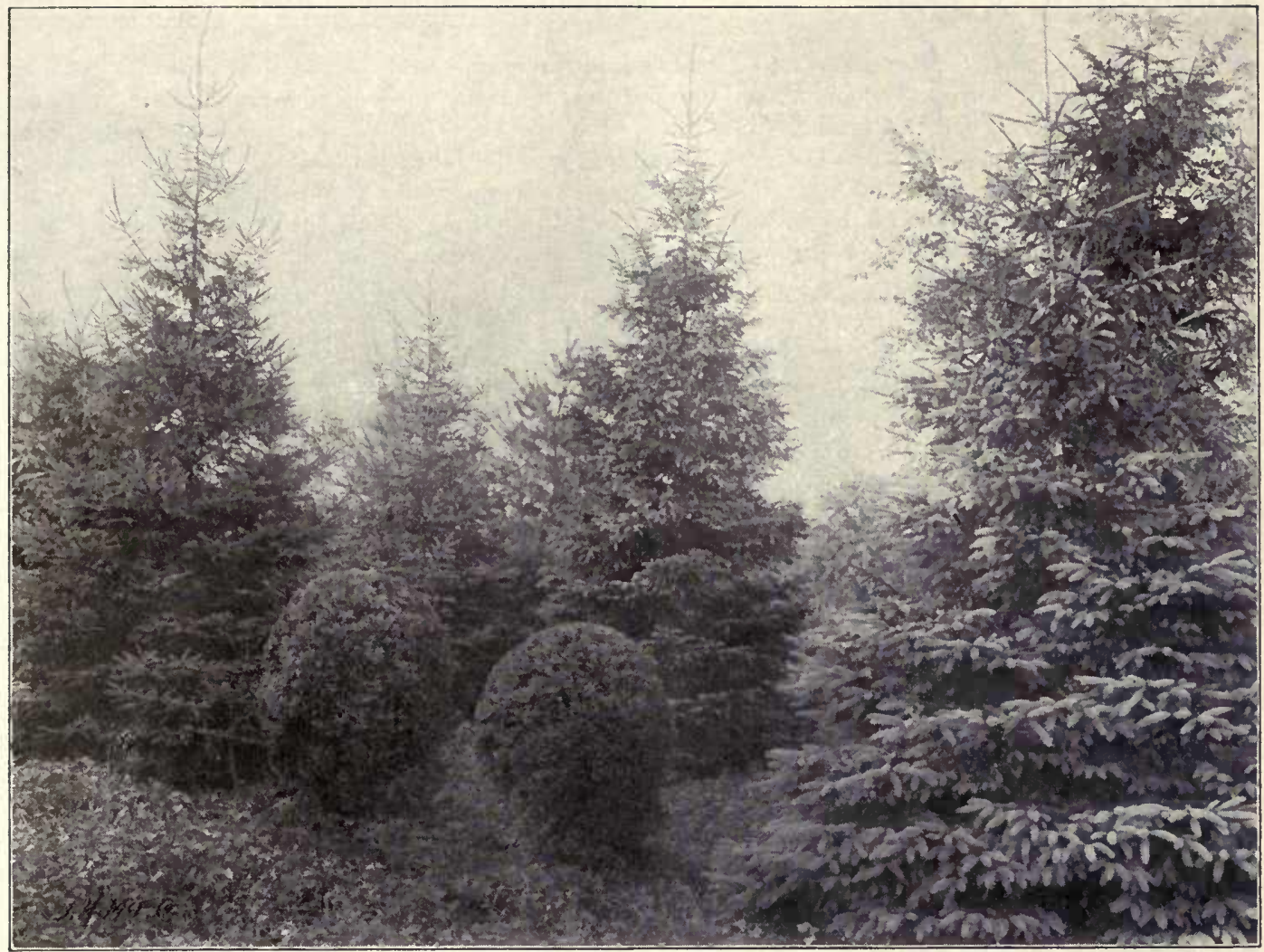

White Spruce, White Pine and Arborvitæ (the latter trained for formal gardening) growing in our nurseries, and ready for transplanting.

\section{Ebergreen Trees (CONIFERS AND TAXIDS)}

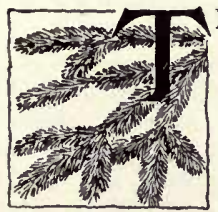

HE beauty of evergreens in the winter landscape will be better appreciated when the cheerful Pines, Fírs and Blue Spruces now available are more extensively planted. There is a richness, warmth and finish to a home embellished with plantations of wellchosen evergreens, in strong contrast to one surrounded only by leafless reminders of the summer.

Evergreens form the most fitting background to the brilliant coloring of the changing autumn leaves, and in spring they give a southern and verdant character on the first sunny day, long before the other trees burst their buds. In summer their foliage often exceeds other trees in beauty.

Belts and groves of evergreens have in their congregated strength the power of shelter and protection. Many a Long Island place, almost uninhabitable from the rude blasts of wind that sweep over its level surface, has been made comfortable; and many a garden, so exposed that the cultivation of trees and plants was almost impossible, rendered sufficiently mild for the growth of tender plants by evergreens. In the lee of such protection the children can play out-of-doors on sunny days all winter, and the early garden operations in March, when the first flowers appear, may be superintended without discomfort.

An evergreen belt north of greenhouses materially recluces expense for coal, Lots in suburban towns will sell readily at higher prices if there are evergreen windbreaks. Garden City and Hempstead do not build up on the north because of this lack.

The ideal arrangement is an open breeze-way over the lawn for the cool southwest sea breeze, a canopy of shade over the house, piazza and terrace, and a shelter-belt on the north of the house and pleasure gardens. Our tree-movers make this possible. Evergreens 15 to 40 feet high are ready. 
The old way was to plant trees I to 4 feet high in the spring, and wait several years for results. By our way, select, write or telephone orders, and evergreens 20 to 40 feet high are delivered any. week in the year. They don't know they have been moved. By the old way many failed, and discouraged planters used but few evergreens, resulting in bare, bleak landscapes. Evergreen foliage constantly calls on the roots for sap. The resin hardens if the roots become dry, and sap cannot flow again. Roots are broken by packing in boxes; and during transit, heat, mould or dry out. Thousands of dollars worth of evergreens die from delay, as waiting for floats across New York

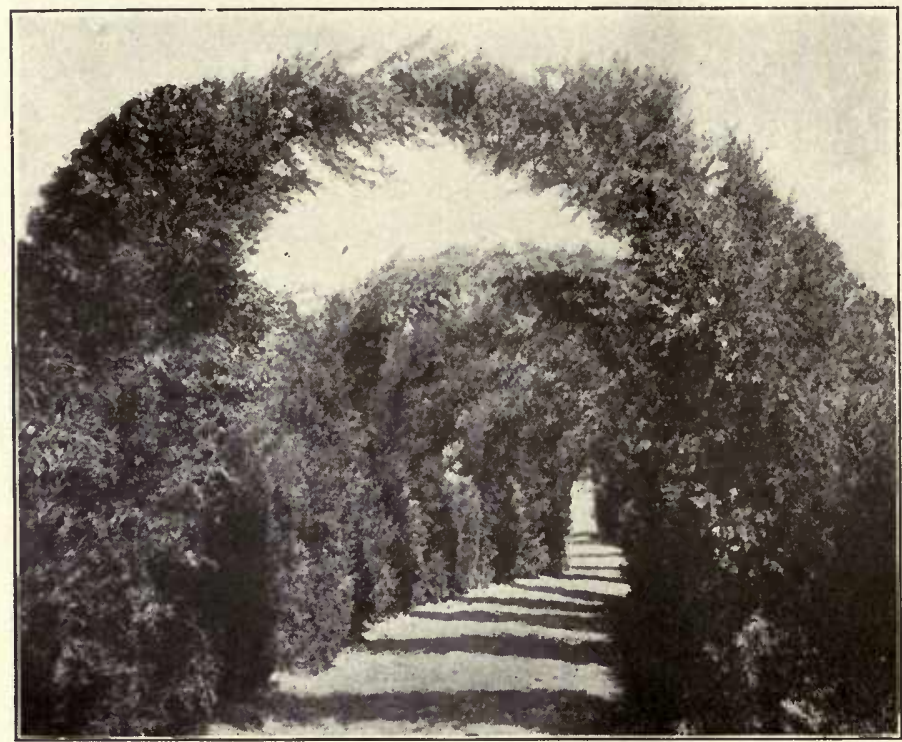

Walk in rose garden at "Castlegould," arched with large evergreens planted by our Evergreen Tree-Mover. Between the evergreen arches are arches of Crimsun Rambler Roses. harbor. More die from inability of newly planted roots, transplanted with little or no earth on them, to supply the foliage with sap. An Oak moved with full foliage would not live. By our method the roots are in a large ball of earth. From Westbury, stone roads radiate, permitting quick transportation. Our movers carry vertically or horizotally.

Iarge trees make immediate, mature and artistic results. In the formal garden, lawn or shel. ter-belt, results may be attained which in the famous gardens of England and Italy have required a century. Evergreens up to 25 feet in height can be shipped by rail or barge.

Small evergreens 6 inches to 6 feet high are offered by the thousand. The same methods insure success.

\section{ARBORVITAE. Thuya \\ WHITE CEDAR OF THE NORTHERN STATES}

American. T. occidentalis. The common Arborvitæ is generally used for hedges, as it stands pruning well and makes a compact, thick screen. In the winter it turns a brownish green color, but quickly changes to a brighter green in March and April. The following is a partial list of its numerous varieties :

Siberian. T. occidentalis, var. Hareana; syn., $T$. Sibirica. This valuable variety has dense compact foliage of pure green color, even in winter. It grows more slowly than the American, and needs less trimming. We offer uniform sheared specimens 2 to 8 feet high for formal planting.

Pyramidal. T. occidentalis, var. pyramidalis. A dark green column suitable for decorating terraces, formal gardens, or for planting in tubs. We offer symmetrical specimens 4 to 6 feet ligh.
Booth's. T. occidentalis, var. Boothii. A globe of compact foliage. Whe have plants 5 feet wide, resembling boxwood, trained as accurately as with a lathe, for terrace decoration

Globe. T. occidentalis, var. globosa; syn., occidentalis compacta globosa. A dwarf button-shaped form of bright green foliage, growing about 2 feet wide, and less in height.

Golden, or George Peabody. $T$. occidentalis, var. lutea. Small trees of a cleep orange-yellow color. Useful in beds of evergreens.

Chinese. T. orientalis; syn., Biota orientalis. This distinct species is a small pyramidal evergreen with flattened upright twigs arranged radially. It is occasionally injured by winter.

Rollinson's Golden. $T$ orientalis, var. eleganlissima. In spring and summer it is a beautiful golden tint, and in winter bronze.

\section{RED CEDAR. Juniperus Virginiana}

This and the Pitch Pine are the most abundant evergreens on Long Island. It adapts its roots to dry and sterile gravel ridges, or to the beach, where they are occasionally covered by a high tide. The foliage stands salt spray well. Evaporation from the foliage is slow, and it will stand drought and dry cold winter winds. Planted on lawns, and fertilized and trimmed, it becomes a handsome, colummar or broadly conical tree, compact, solid and of good green color. It is generally considered difficult to transplant. 


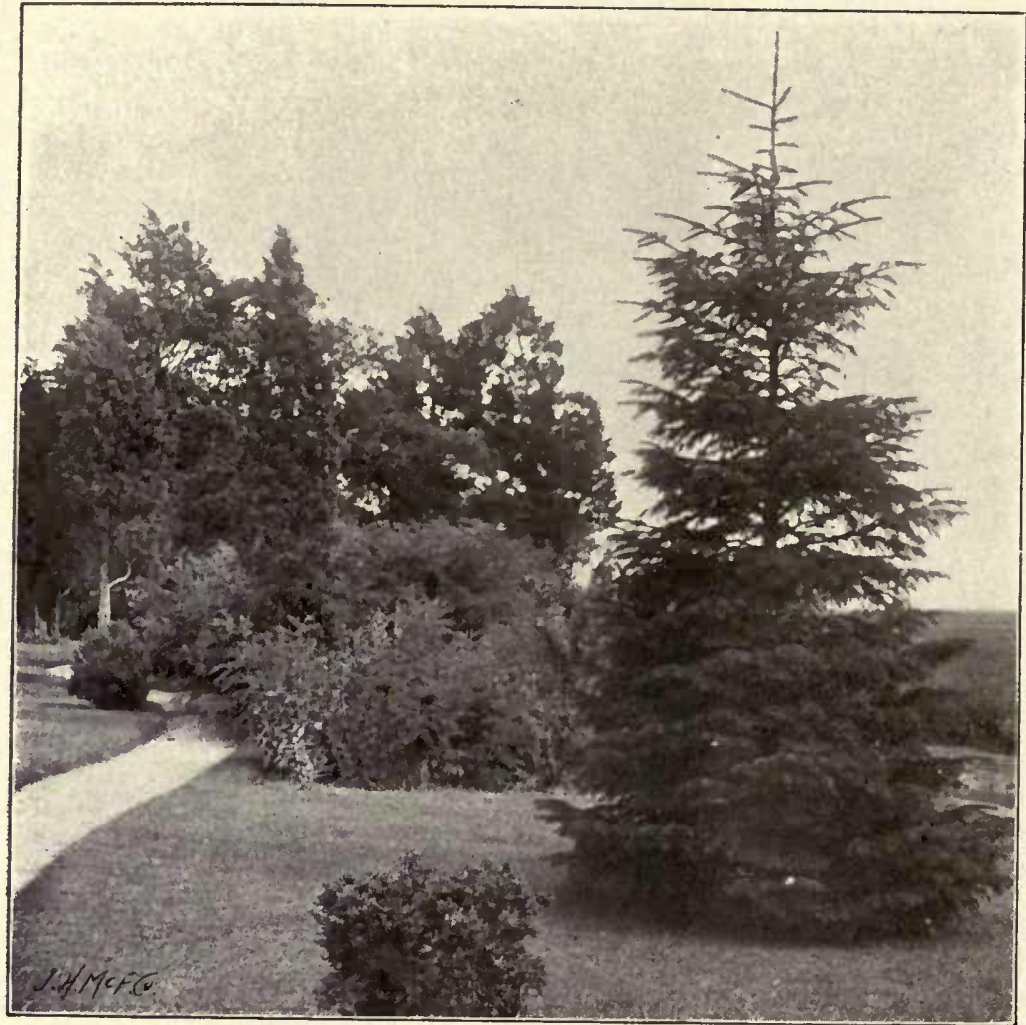

Nordmann's Fir, planted for Mr. Talbot J. Taylor, Cedarhurst, next the salt water, showing its ability to withstand such situations.

pus Koreana. A column of black green foliage 3 to 6 feet high.
broader, assiming a vase form. It is preferable to the Irish yew.

CEDAR, continued Mt. Atlas Silver. $C$. Atlantica, var. glauca. This is the most ad. mired tree at Dosoris, Glen Cove, where the late Chas. A. Dana collected every available evergreen. Its wide arching branches are radiant with silver-blue.

Deodar. C. Deodara. This tree combines the feathery gracefulness of the hemlock and the beautiful glaucons hue of the blue spruce.

\section{CEPHALO - TAXUS}

A genus of the yew family, with foliage as dark and broad as the Nordmann's fir. They are hardy, shade-enduring and prefer moist and sheltered positions.

C. Fortunei. A round bush with graceful branches and lustrous dark foliage, suitable for woodland borders.

C. pedunculata, var. fastigiata; syn., PodocarWhen older the top becomes

\section{FIR. Abies, erroneously Picea}

The Fir family includes some of the noblest trees. They are all conical in form, lofty in height, and, excepting the blue species, are dark rich green in color.

Evergreens add to human comfort, as does a fire or easy chair. They are not merely ornaments. difficult to transplant and liable to look ragged and gloomy. We have the stock, the knowledge and the skill, to make evergreens a success.

Nordmann's. A. Nordinanniana. Connoisseurs award this the highest place among dark-foliaged trees. It is strong and dignified, the broadly ronical outline retaining till old age its widespreading lower branches. The leaves remain on the tree for eight years. They are thicker and wider than those of other evergreens, and are uninjured by salt spray. The Nordmann's Fir usually transplants with difficulty, but ours are prepared to be moved successfully. The specimens from 6 to 14 feet high are the largest and best available.

Silver. A. Picea; syn., $A$. pectinata. There is a specimen 85 feet high in the old Hicks garden on the Winthrop place at Westbury. It closely resembles the Nordmann's Fir. We offer trees to to 16 feet high.

Cephalonian. A. Cephalonica. A valuable hardy tree with dark, sharp-pointed needles. In general appearance it is difficult to distinguish from the Nordmann's Fir. We offer specimens up to 10 feet.
Balsam. A. balsamea. The Christmas tree of northern forests. A useful tree of dark green that loses its lower limbs ifter about a dozen years.

Fraser's Balsam. A. Fraseri. This native of the Apalachian Mountains makes a spire of dark green lustrous foliage.

Concolor, or White. A. concolor. The blue or white green foliage, holding its color thronghout the year, gives this tree a most distinguished appearance. Its shape is pyramidal, with long, upcurving foliage. Among the sharp-pointed evergreens this species and the following will be most highly esteemed when their merits are known: Nordmann's Fir, Colorado Blue, White, Engleman's Oriental and Douglas Spruces.

Lasiocarpa. A. lasiocarpa. Like the Concolor in. foliage, but dwarf and compact in form.

Nobilis glauca. A. nobilis glauca. Similar to the two above species, with which it grows in the Rocky Mountains, this has blue-green foliage. It is dwarf and slow in growth. 


\section{HEMLOCK SPRUCE. T suga, erroneously Abies}

The Hemlocks are very ornamental as single specimens on the lawn and of much utilitarian value in the formation of hedges and screens. They are not particular as to soil, but require considerable moisture.

Common. T. Canadensis. This tree, native to Long Island forests, is perhaps the most graceful evergreen. It will keep the broad sweep of its lower branches until old age, and winter or summer no evergreen excels the purity of its color. Occasional trimming to produce compact growth, or grouping with other trees, prevents the foliage from whipping off in windy situations. It will not stand salt spray; but enduring shade, it should be extensively planted in and along the borders of woodland. It serves well for screening purposes. It is the most beautiful of hedge trees, - when clipped, closely resembling the famous Yew hedges of England. We offer trees up to 25 feet high, and a Hemlock hedge 400 feet long, 3 o years old, 9 feet high and wide, prepared for successful planting.

Sargent's Weeping. T. Canadensis, var. pendula. This forms a flat-topped plant about 5 feet high and twice as broad, with densely clothed branches arching gracefully outward.

Japanese. T. Sieboldi. This evergreen has thicker leaves than the native species, and promises to stand nore exposure.

Carolina. T. Caroliniana. While more open in habit and lighter in color than the native Hemlock, it forms a graceful lawn ornament.

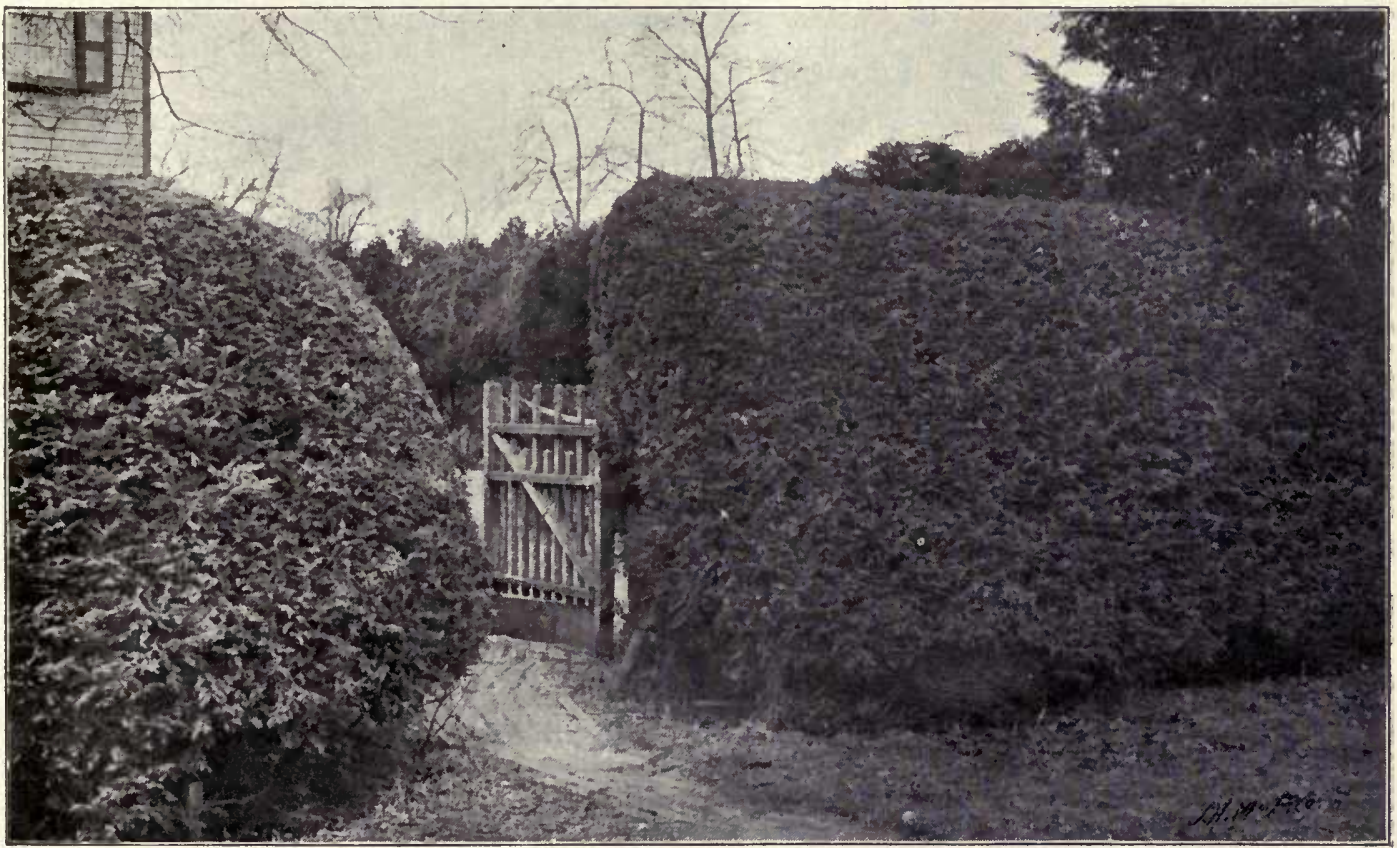

Hemlock hedge at Westbury Nurseries. We have 400 feet of similar hedge, $9 \times 9$ feet, prepared for moving. The only opportunity to reproduce the effect of the old Yew hedges of Eugland.

\section{JUNIPER. Juniperus}

The tall-growing Junipers are noted for the artistic effect they give to a landscape, while the lowgrowing varieties are valuable as ground covering in places where other shrubs or grass will not grow.

Irish. J. communis, var. Hibernica. A narrow, columnar tree of light green. It is liable to winter-kill in part here.

Swedish. J. communis, var. Suecica. Similar in form to the above, but broader and hardier; color light bluish green.

Flat. J. communis, var. Canadensis. This is the familiar evergreen bush which clothes the rocky hillsides of New England and a few parts of Long Island. It spreads over an area io to 25 feet in diameter and 3 to 4 feet in height, forming a mass of graceful upward curving branches of bright green foliage. It is very good for wild hillside planting and foregrounds.
Golden. J. commmis, var. Canaaensis aurea. A brilliant golden mat 2 feet high.

Savin. J. Sabina. A prostrate shrub, growing 3 to 5 feet high, with long, stiff, outward-pointed branches of dark green.

Prostrate, or Trailing. J. Sabina, var. prostrata. This forms a mossy carpet, tempting to walk upon. It grows as a cushion, ro inches deep, or its long trailing branches hug the rocks and hang over the top of a wall or the crest of a surf-beaten cliff. It may be attractively used as a border to a patl, to screen a man-hole cover on the lawn, or to cover ground too dry for grass. A rare plant that should be better known. 


\section{PINE. Pinus}

Economically, the Pines and Palms have been the most valuable trees to mankind. They grow in dry and sterile gravel, and thrive in the severe wind and salt spray. The form of the Pines is broad and round-topped, not spirepointed like the Spruces and Firs.

White Pine. P. Strobus. The largest evergreen of this region, and the most valuable timber tree of the United States. The high price of lumber is largely due to the nearly exhausted original forest, the destruction of the seed-bearing trees, and the failure to provide for future growth of the White Pine. It is now being planted by the million for reforesting lands not suited to agriculture.

The far-reaching branches and their horizontal disposition of lights and shadows distinguish the White Pine above all other trees. It resembles the Cedars of Lebanon as they develop in old English parks. Its nobility of bearing is as impressive as that of the Oaks. There is a serene and settled najesty in a grove of stately old Pines. He who loves tones of color should study the Pine in changes of light and atmosphere,- - soft and gray on a misty day, glistening like blue steel needles in dry clear air, or with a nighty roar beating back the gale with its pliant

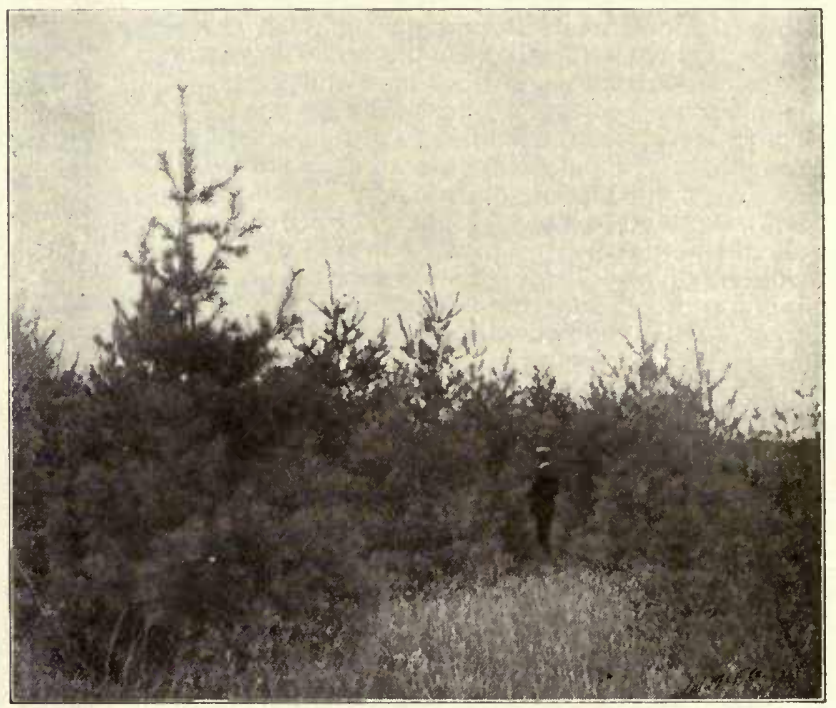

Grove of White Pine planted on abandoned land at Wheatley Hills for Mr. E. D. Morban, 8 years ago. Planted by us when 6 inches high.

green arms. The large size of the tree does not prohibit its use on small lawns, for with annual trimming it remains compact and dense. We offer small Pines, 6 inches to 2 feet high, by the thousand, trees 12 to 25 feet high in lots of rco, and specimens 25 to 45 feet high.

It is possible to immediately attain the quiet and seclusion of old estates on new places, even where close to neighbors or the highway. Until the invention of our movers this was not possible.

Swiss Stone. P. Cembra. A slow-growing symmetrical pyramid of blue-green foliage, suitable for small lawns and groups.

Austrian. P. Laricio, var. Austriaca. The Austrian Pine has stiff, thick and tough foliage that is not injured by wind and salt spray. Beautiful effects are attained at Rockaway, Cedarhurst, The Hamptons and other coast villages on Long Island by 11 s use. With its round-topped staunch bearing it maintains througliout the winter, even when most severe, a pure green color, and is sure to be in good condition in the spring when some others are singed with brown. It can be depended upon for 20 to 25 years, when it begins to deteriorate, but until then it gives as good results as any evergreen, for such trying situations. It shot!ld be planted on the windward side of groves of longerlived species.

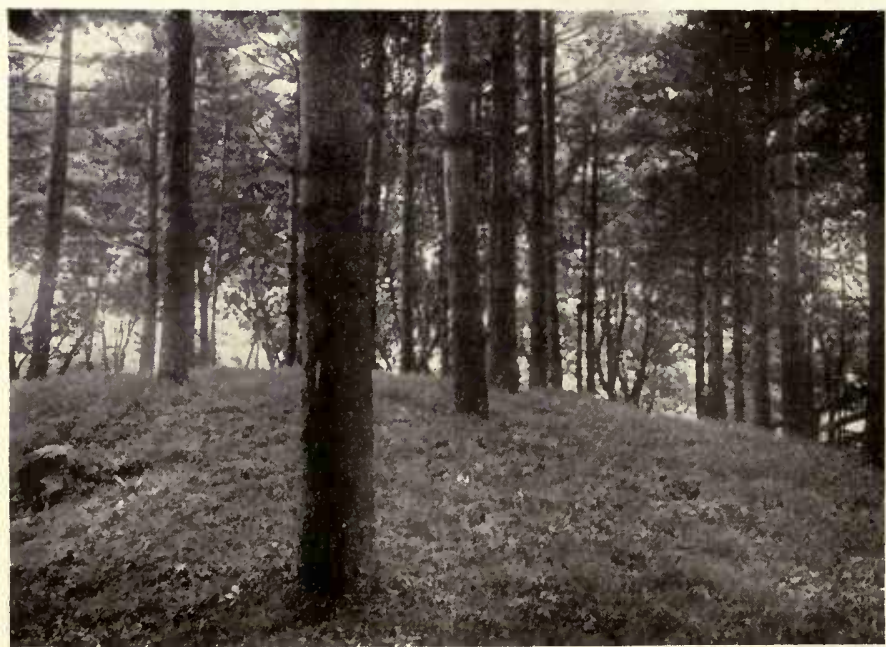

Forest of White Pine planted about 30 years ago for Mr. John D. Hicks. The trees have grown to over 2 feet in diameter.
Scotch. P. sylvestris. Resembles the Austrian in all its qualities, excepting that the foliage is bluegreen and shorter. It is equally valuable on sand hill or seashore.

Pitch. 1. rigida. Nature has planted this tree over thousands of acres of Long Island. It is generally seen where fire has impoverished the soil and burned its branches, but it is capable of making a handsome roundheaded tree. To cover bare hills and to hold drifting sand it is unexcelled. We offer small plants in quantity for this purpose. It helps other trees by improving the soil and protecting them. The Stone Pine of Italian gardens, with its tall stem and dome top, may be duplicated by the Pitch Pine.

We can supply large trees of various types. 
PINE, continued

Reu, or Norway. P. resinosa. A tall tree, native to Maine and westward. It is distinguished from the Austrian Pine only by its darker green color. It is a handsome long-lived tree that merits extensive use.

Mugho. P. montana, var. mughus. This dwarf in a family of giants has many places of usefulness; as a low cover on road banks, terraces and hills, or as a lawn specimen. It is a compact, buttonshaped bush, 2 or 3 feet high and twice as wide, eventually becoining to feet high. It has been trained by the avalanches of the Alps to lie flat and spring up again uninjured.

\section{UMBRELLA PINE. Sciadopitys}

S. verticillata. A small garden or lawn tree which attracts attention by its dignity, refinement and aristocratic bearing. It is a pyramid of graceful, Justrous foliage. The leaves are 5 inches long and $1 / 4$ inch broad, arranged in a circle like the rays of an umbrella. See page 65.

\section{PODOCARPUS. See Cephalotaxus}

\section{RETINOSPORA}

\section{(Japan Cypress). Chamaccyparis}

A Japanese genus of delicately beautiful evergreens chiefly remarkable for their gracefulness and the varied coloring of their plumy foliage. They are especially valuable for grouping in situations too small for the larger pines and spruces.

R. plumosa. C. pisifera, var. plumosa. Usually in the shape of a pyramid 3 to 8 feet high and wide, with light green foliage.

R. plumosa aurea (Golden Japan Cypress). C. pisifera, var. plumosa aurea. This is the best known variety. Its deep golden yellow foliage is brilliant all the year and adds a cheerful note to the landscape.

R. squarrosa (Blue Japan Cypress). C. pisifera, var. squarrosa. The silvery blue member of the family is a charming little tree. Its bright and fleecy foliage and happy expression win friends for it winter and summer.

At Newport the above three varieties are largely used in pattern bedding. Scroll form beds are filled with contrasting varieties of Retinospora, arborvitæ and yew, sloping upward to taller plants of hemlock and fir. Such groups are often used against recessed walls at entrance
RETINOSPORA, continued

gates, at the angles of walks and drives, and borders of the lawn. We have a large stock in pyramid and dome form, 2 to I 2 feet high, for decorating formal gardens, for planting next to foundations of a house, for tubs and terra-cotta urns, for winclow boxes, and for grouping on the lawn. Annual shearing preserves their compact appearance and improves their color.

R. filifera. C. pisifera, var. filifera. This is a light green pyramidal tree with thread-like branches 8 to 4 inches long, gracefully arching over its surface.

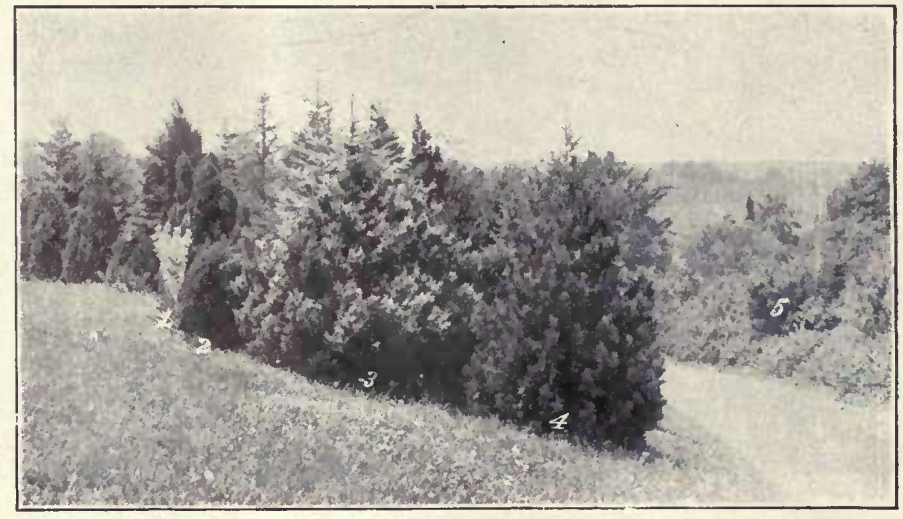

Group of evergreens on lawn of Mr. Hamilton Carv. I, Yucca; 2, Arborvitæ; 3 Retinospora plumosa aurea; 4 , Swiss Stone Pine; 5, bank of Thun-

R. obtusa. C. obtusa. This distinct species differs from the gracef $t 11$ and delicate forms of the above in being dark green, strong, rugged and hardy in appearance. In Japan it is an important timber tree, and is wortliy of general planting here. Fifth Avenue auction rooms sell at fabulous prices the Chabo Hiba as 200 years old, the heirlooms of the ancient families. The skilful Japanese manufacture them from this species, twisting it in grotesque forms and grafting on numerous little branches of the dwarf variety. It then resembles the quaint gnarled plants made by patient dwarfing and starving in little pots for several generations.

R. obtusa nana (Japanese Dwarf Cypress). C. obtusa nana. A curious compact little plant contorted as if it struggled witl fate on the cliffs of alpine summits or by the sea where the wind twisted and buffeted it about. Each plant grows after a different plan. It may be used in rockgardens or wherever a touch of darkest green in small form is needed. A weird and unique plant. There is a golden form of this beautiful variety.

\section{SPRUCE}

\section{Picea, erroneously Abies, including Pseudotsuga}

The Spruces are all tall spires and popularly classed with the Firs. These and the pines are the most inportant large evergreens for landscape planting. They are sprightly, alert, cheerful-looking trees, native of Arctic and mountainous regions. Those listed are well adapted to our soil and climate, and groups may be planted in the most windy situations. The Colorado Blue, Engelmann's and Douglas' Spruces and Concolor Fir, all from Colorado, and the White Spruce, are a brilliant, cheerful, and energetic addition to the landscape. 


\section{SPRUCE, continued}

Mr. August Belmont's Hempstead estate shows good examples of the rejuvenation of old Norway Spruce trees. They were 80 feet high and had become scraggy and ragged at the top. Twenty feet were cut off and the side branches shortened to a point preserving the natural form, and the roots fertilized. Three years afterward the tops are dense, compact and handsome.

White. P. alba. A bright blue-green tree of bandsome compact form. Large trees here attest its ability to retain these qualities in old age. It is a native of Maine, but is less plentiful than the more somber black and red Spruces. Its color often equals the Colorado Blue Spruce. TVe offer specimens ro to 15 feet high, trained uniformly for formal gardens, and larger trees 16 to 22 feet.

Engelmann's. $P$. Engelmanni. A rare and valuable conifer with dark green foliage, lighter underneath. Perfectly hardy.

Oriental. $P$. orientalis. Closely resembles the Nordmann's Fir in its dark rich color and dense habit. Its short, black-green leaves are retained for nine years. Native of Siberia, its hardiness is undoubted.

Colorado. P. pungens. The sage-green color and strong needle-pointed leaves on stiff, slielf-like branches make this a beautiful and conspicuous tree. It is a strong, stern tree and can stand salt spray. In early summer its color approaches that of the variety.

Colorado Blue. $P$. pungens, var. glauca. This conspicuous lawn ornament has become more quickly known and appreciated than any other evergreen. It instantly attracts the eye and forms the center of the picture. It cheerfully lights up a dark corner and harmonizes with a background of White Spruce and darker Firs and Pines. The scintillations of its silver sheen are like a lace of hoar-frost sparkling in the sun.

Koster's Colorado Blue. P. pungens, var. glauca Kosterii. This is grafted from an extra blue tree.

Alcock's. P. bicolor; syn., Alcockiana. Viewed by the horizontal rays of the afternoon winter sun illuminating the under side of the ascending branches, it is the most brilliant blue evergreen.

Norway. $P$. excelsa. On Long Island the Norway Spruce does the most toward breaking the flatness of the winter landscape. Groups of them tower to twice or three

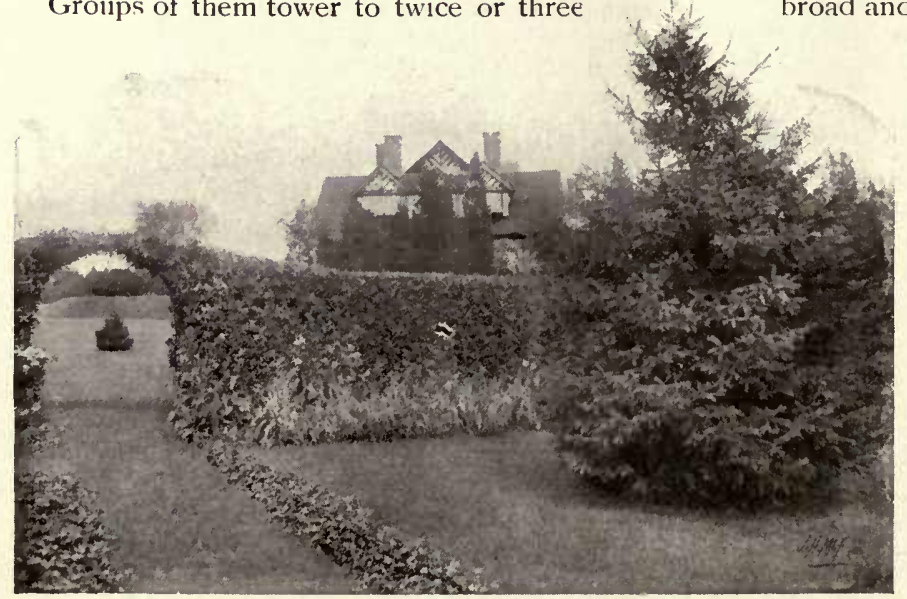

Privet hedge and arch at residence of Mr. Talbol J. Taylor, Cedarhurst, L I. At the right is a large White Spruce.

\section{NORWAY SPRUCE, continued}

times the height of the farm-houses they shelter. Rapid-growing, dark green, graceful and dense when young, it is worthy of extensive planting for hedges, shelter-belts and screens. We offer 60 trees ro to 20 feet, 20 trees 20 to 30 feet. high, and small ones in quantity. All can be shipped by rail.

Weeping Norway. P. excelsa, var. inverta. An erratic curiosity growing I 5 to 20 feet high, with branches hanging fantastically downward.

Douglas. Pseudotsuga Douglasii. This promises to be the most valuable Spruce for general planting. It grows rapidly to a dense, graceful tree of soft light bluish green foliage, which does not get thin, ragged or brown. The Colorado form is hardy ; that from California tender.

\section{YEW. Taxus}

The Yews are all shade-enduring and have very dark green foliage. The Yew family is famous in literature through the ancient Yews of Europe, which we have the good fortune to be able to grow here. This latitude is their northern limit for this country. A little winter protection of straw or the shade of other trees is sufficient to prevent their becoming brown in severe weather.

English. T. baccata. In this resion the Engli:sh lew grows as a broad bush of many stems of darkest green foliage.

Golden English. T. baccata, var. aurea. A little plant of bright golden yellow.

Irish. T. baccata, var. fastigiata. A narrow dark column. Needs protection in winter.

Canadian. T. Canadensis. The spreading branches of the Canadian Yew cover the ground like green carpet, forming in time a mat I 5 feet broad and $I \frac{1}{2}$ feet high. It will grow in damp. shady places. It has bright red berries.

Japanese. T. cuspidata. This is perfectly hardy, and there should be an active demand for it. At Dosoris, Glen Cove, the estate of the late Charles A. Dana, we have moved an old specimen of this species $2 \mathrm{I}$ feet wide and $\mathrm{I} 5$ feet high. It has not browned in most severe exposure to north winds or bright winter sun. We have seed and layers of this stock.

Dwarf Japanese. T. cuspidata, var. brevifolia. On the same estate are specimens of this, I5 feet wide and 3 feet high. It is a rugged, dark green plant, as if from up near the snow line. We have moved one of these to the nursery and layered, to make new plants. 


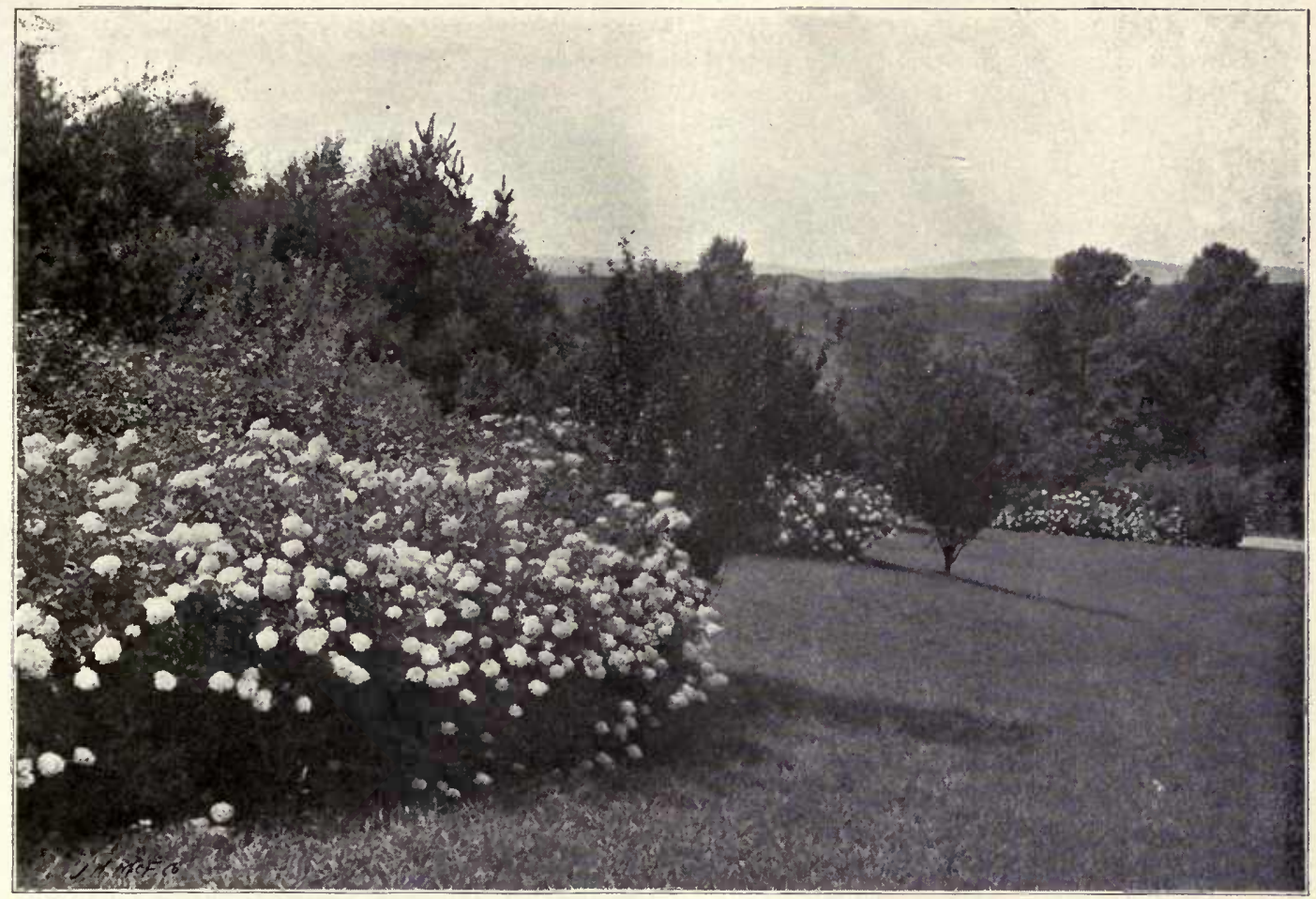

View on the estate of Mr. Hamilton Cary, showing a hill covered with Pine, Birch, Dogwood, Deutzia and Forsythia, flaked with groups of Hydrangea paniculata grandifora. A planting that cares for itself.

\section{Flowering Shrubs}

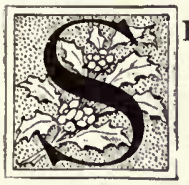

HRUBS are a necessary complement to trees in the landscape. In two or three years the shrubbery on a new place looks mature. With shrubs 6 feet high and trees 25 to 50 feet, mature results are attained the first year. The varying color, form and shadow effects from April to October, of flowers, foliage and bright berries are not exceeded even by the flower garden. The colored twigs are beautiful in winter.

To screen laundry and service court, kitchen, stable or road, tall shrubs are valuable. We offer shrubs 7 to ro feet high for this purpose. To carry the green of the lawn over a drive, a belt of low shrubs will preserve the unbroken sweep of green which is the keynote of a landscape. To round off the angular lines at the foundation of a house and connect the house with the ground, shrubs are indispensable. We train compact and symmetrical shrubs for the purpose.

Grading with shrubs is an economy little understood. For example, a road curving around a hill may have a steep and dangerous bank. Dense shrubs, as Berberis Thunbergi backed by taller shrubs, will make a thicket that will halt a bolting horse. With the same economy, masses of shrubs will fill in hollows or round off rough hillsides. See illustration, page 43.

A prominent landscape architect says: "The foliage of shrubs that are well established remains green when dry weather turns grass brown. The broad mass of shrubbery will take care of itself when the grass needs frequent attention. It might with advantage replace grass upon all surfaces too steep to walk upon with comfort," and it might be added, too expensive, or impossible, to keep in good lawn.

Plant in broad masses, using large quantities. Group similar kinds together blending into the next. Long, graceful curves for outlines, with detached groups, produce most beautiful results and permit economical nowing with a horse lawn-mower. Plant low, thick-foliaged kinds, as Berberis Thunbergi, Deutzia gracilis and Rugosa Rose at the front, to hide the bare stems of those in the rear and hold the mulch.

Prepare the ground and maintain it as for a crop of potatoes, or mulch with straw, leaves or thatch.

To cover ground too poor and gravelly for grass, plant Wild Rose, Rugosa Rose, Trailing Rose, 
Bayberry, Sumach, Acacia, Indigo Shrub, Inclian Currant, Huckleberry, Bearberry. For seaside exposure, drifting sand and bluffs, see Introduction, page 5 .

To brighten up shrubberies, in August and later when most are past blooming, we have grown many varieties of late-blooming shrubs and tall herbaceous plants, as well as those conspicuous for foliage and bright berries.

In pruning shrubs, avoid the prevalent dome top or balloon-shaped style. It results in few flowers, for flower-buds are made the previous year, excepting those of the Althea, Hydrangea and other late blooners. Prune out the oldest and most scraggy branches immediately after flowering, or take out a few each winter.

Houses completed in May or June need shrubs around them. We have shrubs prepared for successful transplanting at any time.

\section{ACACIA (Rose Acacia) Robinia hispida}

An old-fashioned shrub of open, irregular habit, 3 feet high, with clusters of deep pink flowers resembling sweet peas in June and July. It will grow in poor soil and is useful for seaside planting.

\section{ALTHEA (Rose of Sharon)} Hibiscus Syriacus

In late summer the Altheas and Hydrangeas are the brightest ornaments to the shrubbery. The hollyhock-like flowers range in color through white

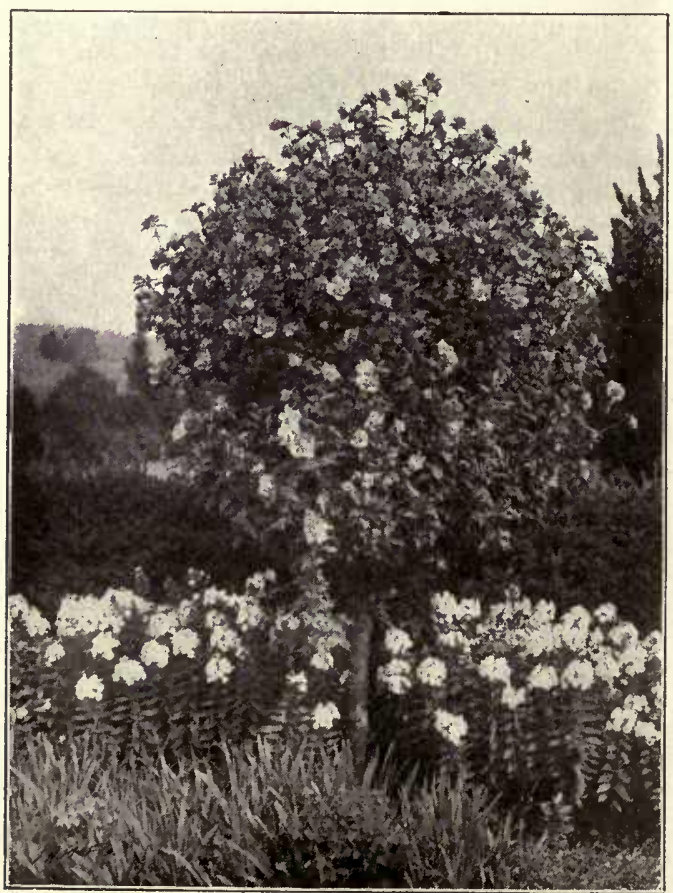

Althea trimmed to tree form, with hardy perenuial phlox growing below.

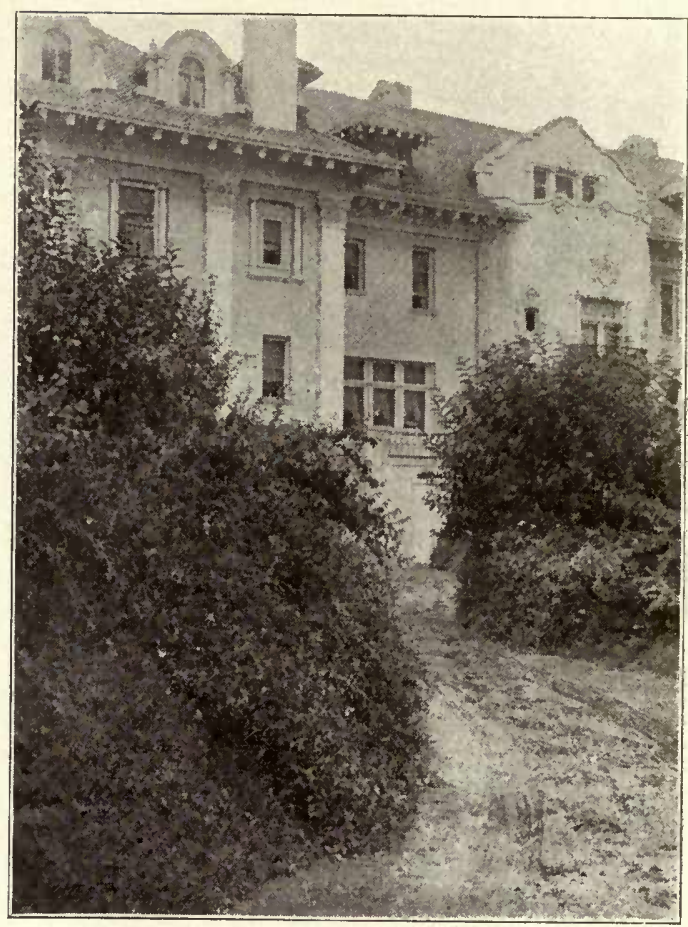

A new solution of the service court and laundry paddock problem. Court sunk to the basement level and having vertical walis of foliage, thus preventing a view from the street. The walls are $!$ ilt at a steep angle by laying sod, like bricks, with Honeysuck ] between, and weeping Forsythia at the top. Residence of Mr. Alexander C. Humphreys, North Country Colony, Glen Cove, L. I.

, pink and red, double and single. As a garden hedge it may be pruned each year and yet flower freely.

\section{AZALEA (Rhododendron)}

The Azaleas are the deciduous or leaf-dropping members of the Rhododendron genus. They are so beautiful that a collection of varieties is an essential in any scheme of lawn decoration. All the Azileas when wild are under-shrubs in the woods, and, therefore, are well adapted for massing along the borders of woodland, or edges of streanis and springy places.

A. amœna. See Broad-leaved Evergreen Shrubs.

Chinese. A. mollis. A vigorous round bush, covered in early May with large trusses of blossoms resembling the Rhododendron in form. The colors are lemon, yellow, salmon, orange and orange-red.

Flame. $A$. calendulacea. The brilliant colors of this species, ranging from yellow to orange-red, render it particularly attractive when planted in the shadowy borders of the woods.

Ghent. A. Pontica. A class of numerous varieties that are hybrids between the species of this country and that of the Himalaya mountains. They represent all the colors of the genus in many variations, beautifully shaded, and are both single and double. The flowers have the form of our native Azalea, and are especially pleasing in delicacy of color. 


\section{AZALEA, continued}

Pinxter Flower. A. mudiflora. One of the rarest gems of our woodlands. It is an open and graceful shrub bearing a profusion of bright pink flowers in May, as the leaves appear. We offer it by the hundred for planting in masses.

Southern. A. Vaseyi. This rare and new species from the North Carolina mountains is particularly charming with its delicate shell-pink flowers. One of the most beautiful of recent introduction.

Swamp. A. viscosa. When passing low, moist ground in midsummer, the perfume of the white flowers of this shrub is plainly noticeable.

\section{BAYBERRY (Wax Myrtle) Myrica cerifera}

A rich dark green bush of rounded form, a slow grower, reaching 9 feet in height. For clothing sterile hills, bluffs and sand-dunes, it is unequaled.

\section{BARBERRY. Berberis}

European. $B$. vulgaris. An European species that has established itself on rocky hillsides. It is an upright, graceful shrub, 6 to Io feet high, ornamented during autumn and early winter with clusters of red berries.

Purple. B. vulgaris, var. purpurea. One of the best shrubs with purple foliage. The young shoots are bright red, and in May it has drooping racemes of sniall yellow flowers.

Japanese. $B$. Thunbergi. There is always need at the borders of shrubbery for a plant that will keep its foliage close to the ground. Berberis Thunbergi makes so close a mass of twigs that even in winter it fulfils this purpose. The foliage is a glossy bright green, turning to scarlet in autumn, and its coral berries hang on all winter. It thrives on all soils. A valuable hedge plant.

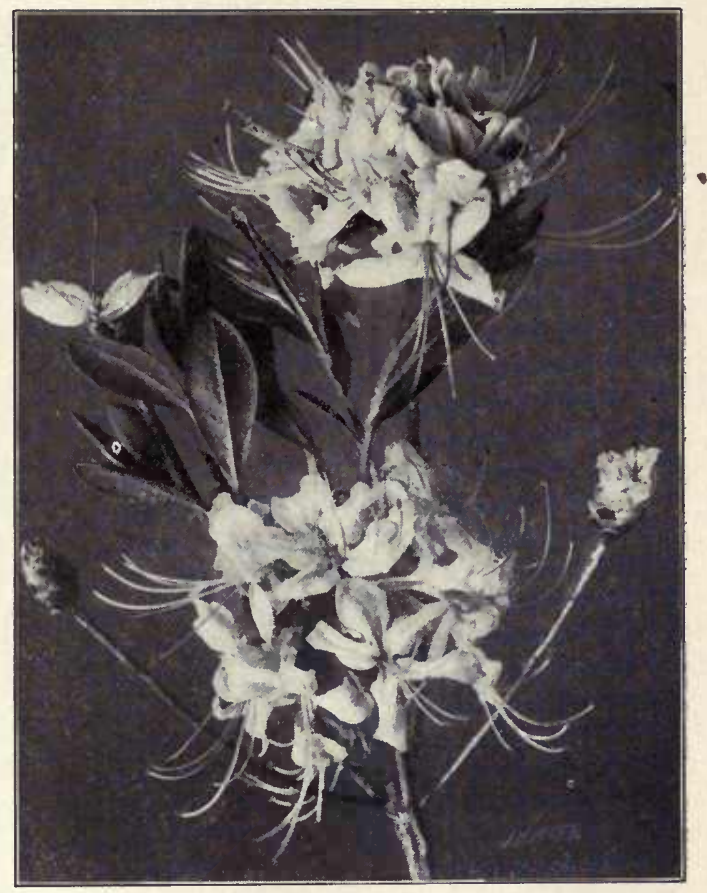

Flowers of Azalea nudiflora.

\section{BUTTON BUSH. Cephalanthus occidentalis}

A useful shrub from the fact that it will thrive where the roots are covered with water in winter and spring, or on upland. The large leaves are dark green, and in midsummer it has white flowers in the shape of a button-ball. Form rounded, height 6 feet. Particularly appropriate in wild planting about ponds and lakes.

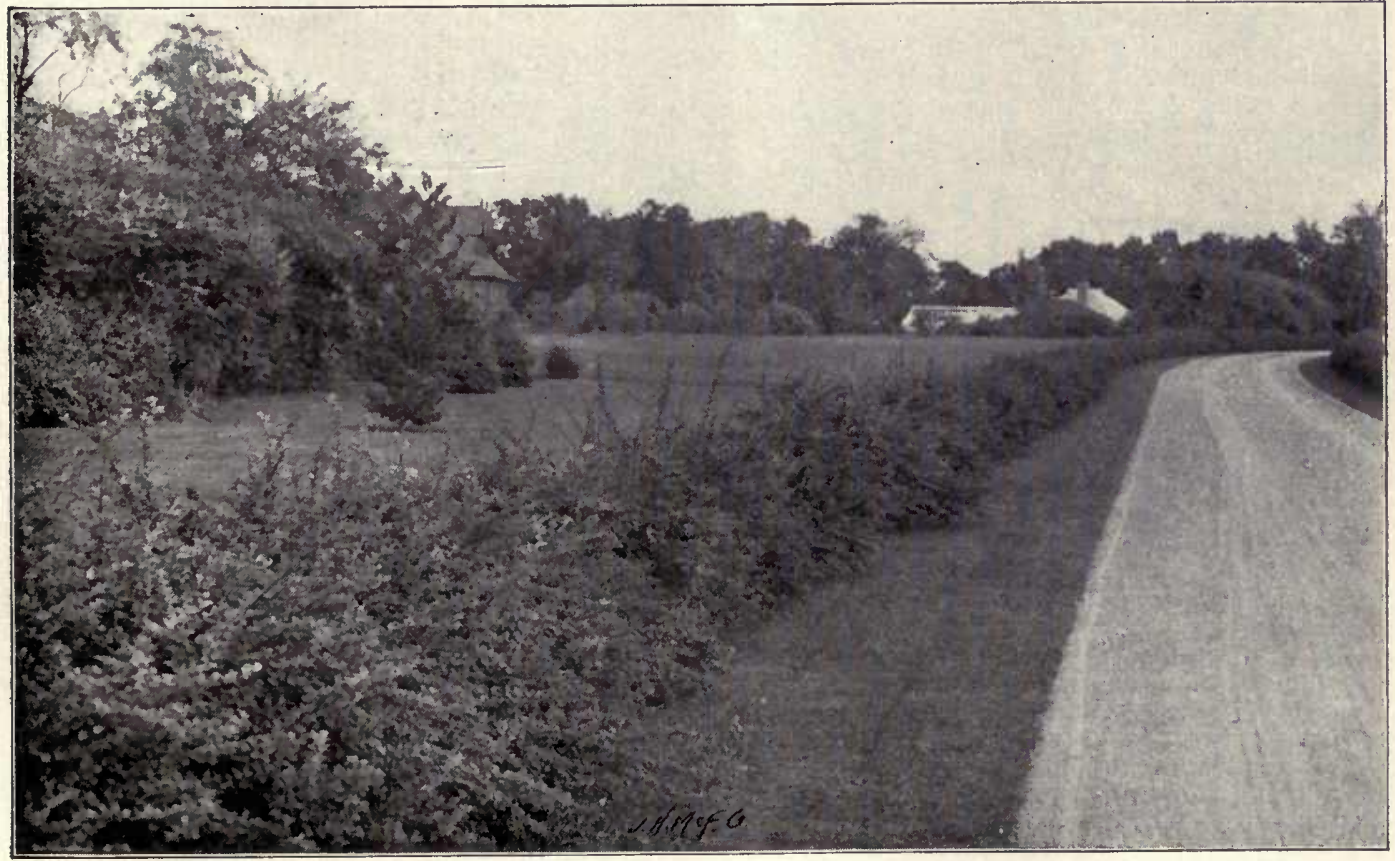




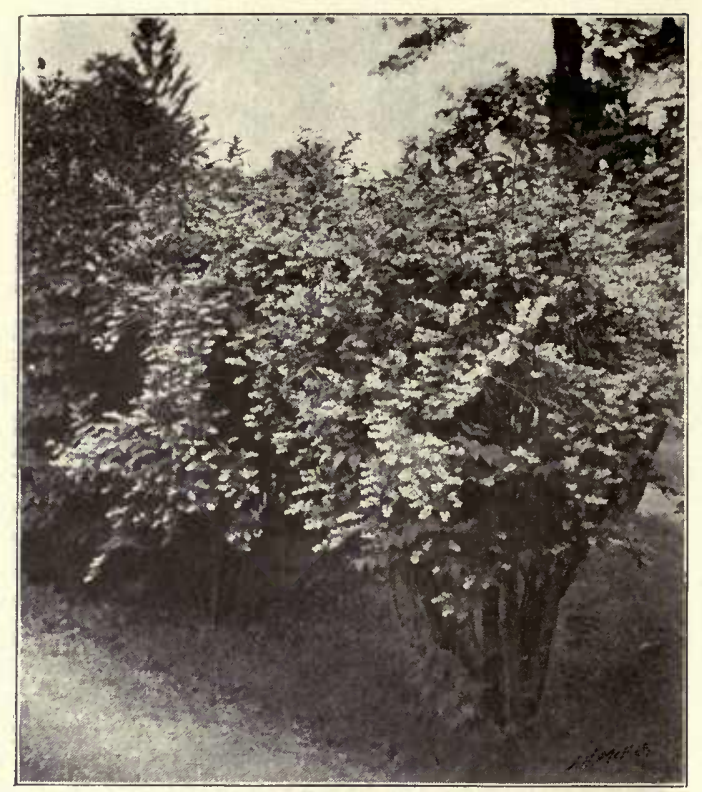

Deutzia crenata, a splendid tall shrub, that needs a lowgrowing shrub, such as Thunberg's Barberry, in front of it, to hide the bareness of its trunk.

\section{CATALPA}

C. Bungei ; syn., bignonioides, var. nana. A dwarf tree or shrub from China, growing from 3 to to feet high. The leaves are very large and thick, which makes it suitable for seaside planting.

\section{CORCHORUS}

\section{Kerria Japonica}

Among the Boxwoods about many old farmhouses, the graceful green stems of the Corchorus are seen, bearing brilliant golden balls throughout the summer.

\section{DEUTZIA}

The Deutzias are among the most useful of tall shrubs, forming sturdy upright bushes 8 to I2 feet high, with thick foliage that makes a good screen. The four varieties, D. scabra, D. crenata, D. candidissima, and Pride of Rochester are similar. In June they have showy white flowers, sometimes tinged with pink.

Dwarf. D. gracilis. Japanese Snow Flower. A broad, sturdy bush I to 3 feet high, wreathed with a profusion of delicate white flowers in June. Where a shrub is desired that does not grow out of bounds, as against the foundation of a house, near a path, or edging tall shrubs, this is to be recommended.

\section{DOGWOOD. Cornus}

Red-twigged. C. alba, var. Sibirica. In the winter this is the most showy of all the shrubs, standing out bright and cheerful with its brilliant red bark. It should be planted in groups where its color effect is visible at a distance. It has healthy, compact foliage, white flowers and white berries.

c. sanguinea. Dark red branches.

\section{ELDER. Sambucus}

Golden. S. nigra, var. aurea. A tall coarse shrub with clear yellow foliage throughout the summer. It should be planted at a distance for bold color effects.

\section{ELAEAGNUS}

E. umbellata. Silver Thorn. The Elreagnus is distinguishable by the silvery coating to the leaves, which forms a harmonious and striking contrast with other shrubs. It thrives especially well near the sea. In late summer and autumn it is covered with bright red berries, pleasantly acid.

E. longipes. Recently introduced for its cranberrylike fruit ripening in July, at which time it is highly ornamental.

\section{EXOCHORDA. Pearl Bush}

E. grandiflora. A shrub that is admired above others in May for its graceful festoons cf large pure white flowers. It is somewhat open and irregular and is therefore better planted at the rear of other shrubs than standing alone.

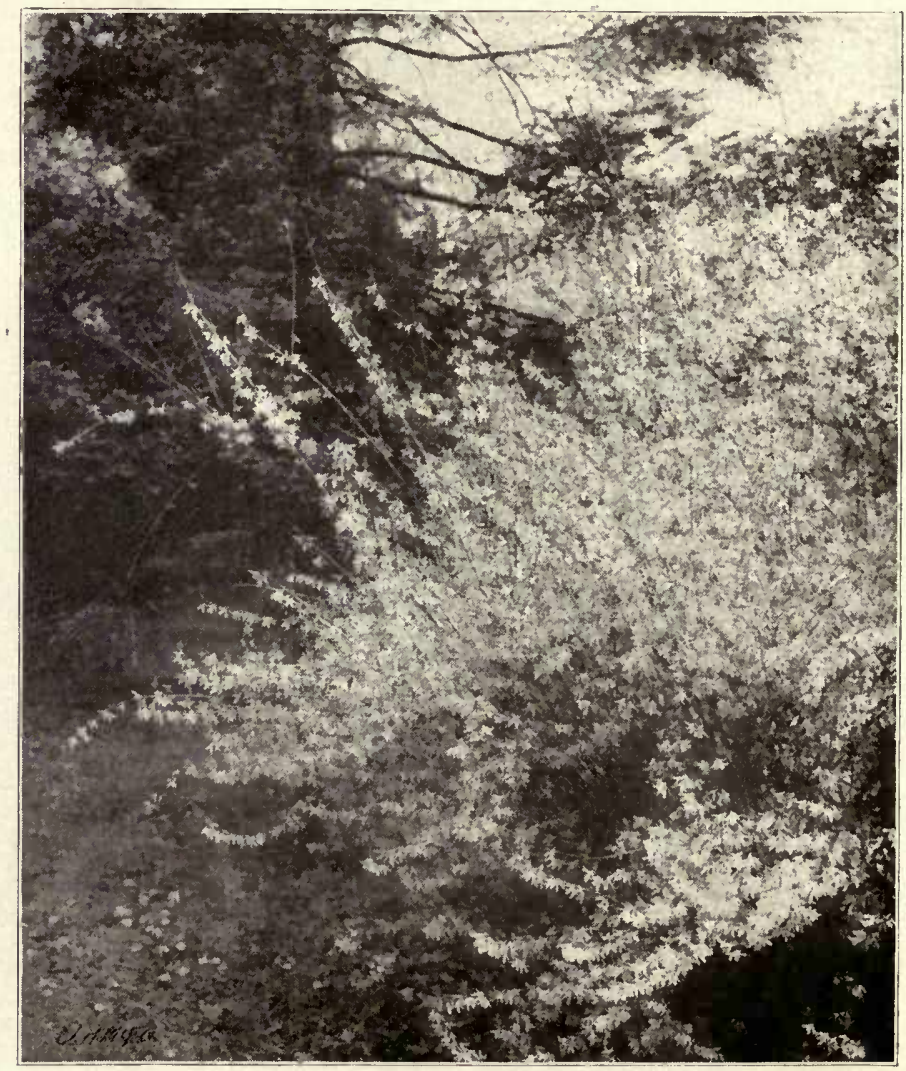




\section{FORSYTHIA. Golden Bell}

The first shrub to make a conspicuous display of flowers is the Golden Bell, when its cheerful golden note in the landscape welcomes the spring: During the summer it maintains such luxuriant foliage that it is to be recommended for making tall thick screens and for covering steep banks.

F. Fortunei. F. suspensa, var. Fortunei. An upright shrub similar to the others, excepting that its yellow flowers are larger.

F. suspensa. A shrub of gracefully arching branches, which droop to the ground when it becomes mature. It is valuable in the margins of gromps and to cover banks.

F. viridissima. An upright shrub with green stems and dark glossy leaves that turn to a rich purple in alutumu.

\section{FRINGE. Chionanthus}

White. C. Virginiana. A large shrub or small tree with rich dark foliage that makes it a worthy companion to the Magnolia. On vigorous specimens the leaves resemble the India rubber plant. In June the graceful lace-like white flowers hang in drooping panicles between the leaves.

\section{GOLDEN BELL. See Forsythia}

\section{HERCULES' CLUB (Angelica Tree)}

\section{Aralia spinosa}

The tropical luxuriance of the Aralia gives it a distinct appearance. On top of the tall, spiny stem is a crown of leaves 2 feet long, with a cluster of fleecy white flowers in its midst. It spreads by underground suckers and gives a quick effect in new shrubberies, or in wild rough places.

\section{HONEYSUCKLE. Lonicera}

Upright. L. Tatarica. One of the best classes of shrubs in every respect. They have a sturdy oak-like habit, growing 6 to Io feet high, and have good foliage, which renders them useful for screens and masses. They are made attractive by a profusion of small white, pink or red blossoms in May and June, followed by clusters of translucent coral berries in the fall.

L. Standishi. Sometimes, before the last snowstorm in March, this shrub bears its spicy creamcolored flowers.

\section{HORSE-CHESTNUT. Esculus}

Dwarf. AE. parviflora; syn., macrostachya. By the middle of July when many flowering shrubs that have made the borders gay are past, and the autumn-blooming Hydrangea and Althea are still to come, this gap is admirably filled by the Dwarf Horse-chestmut. It is a broad, slowgrowing shrub, carrying upright panicles a foot long, of fleecy white flowers. The foliage is always in good condition and it becomes a handsome lawn clump. This rare shrub should be more extensively used in landscape planting.

\section{HYDRANGEA}

II paniculata, var. grandiflora. This is the most showy shrub of late summer, with its immense plumes of white flowers, which become bronze in autumn and remain on the bush till winter. When closely pruned and fertilized, the plumes are over a foot wide. If planted in groups, the effect is a compact mass of white. See page 45 .

H. Hortensis, var. Otaksa. The Hydrangea witl pink or blue flowers, which is usually grown in tubs. It is hardy, with slight protection, near the north and south shores of Long Island.

H. radiata. A low shrub, that is noticeable because the leaves are white underneath; has small flat flowers.

H. quercifolia. Oak-leaved Hydrangea. A rare and interesting shrub with large leaves resembling the Red Oak. It has open panicles of white flowers.

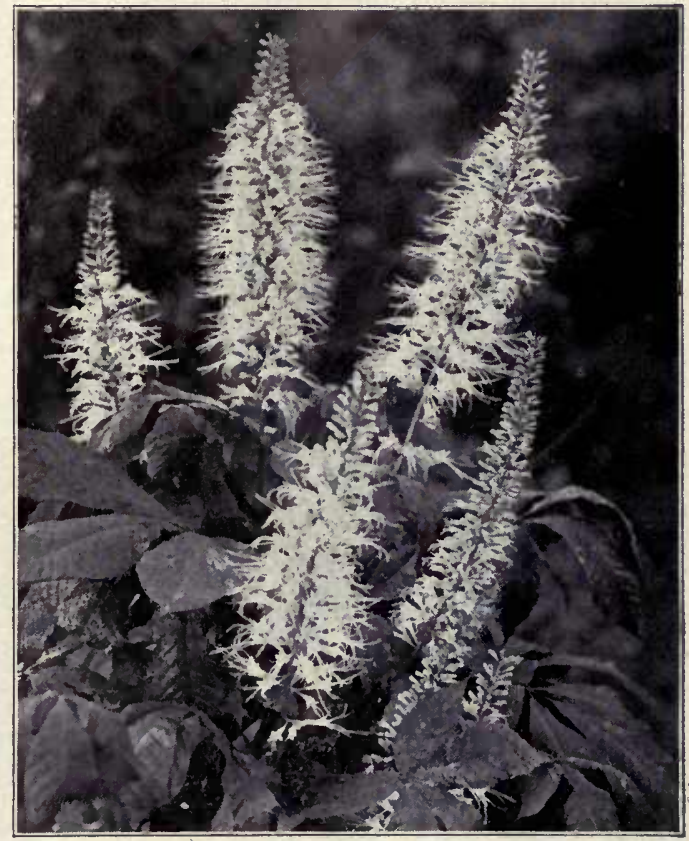

Flowers of Dwarf Horse-chestnut.

\section{INDIAN CURRANT (Coral Berry)}

\section{Symphoricarpus bulgaris}

The long runners of this shrub reach out like those of the Strawberry, and take root, enabling it to hold steep banks. Its low growth fits it for use in borders, where it is especially attractive in autumn and winter with its masses of coral berries.

\section{JAPANESE JUDAS \\ Cercis Chinensis; syn., Japonica}

A broad bush, the twigs of which are encircled with bright rose-colored pea-shaped flowers early in May, before the smooth, heart-shaped leaves appear. It makes a brilliant spot in the shrubbery. 


\section{LABURNUM. Golden Chain}

L. vulgare. A tall, slender shrub, or small tree, having delicate pea-green foliage festooned in May with racenes of yellow flowers similar to the wistaria.

\section{LILAC. Syringa}

All who love the old-time flowers have an affection for the Lilac. To the newer varieties are to be credited improvements in size, color and texture. We are growing these in quantity and can strongly recommend them. They are best grown on their own roots. If grafted ones are used, plant deep enough for roots to form above the graft.

\section{NAMED VARIETIES OF SYRINGA VULGARIS}

Charles X, Louis Van Houtte, Marie Legraye, Ville de Troyes, Virginalis, Mme. Lemoine, Le Gaulois, Emile Liebig, Ludwig Spaeth, Frau Dammann, Condorset, and others.

Common. S, vulgaris. A tall shrub with fragrant lilac or purplish flowers. The foliage generally becomes mildewed in late summer, so that it is better planted in the rear of plants with good foliage.

White. S vulgaris, var, alba. Similar to the above, with fragrant white flowers.

Persian. S. Persica. This has slender arching brátiches, bearing clusters of flowers all along their length.

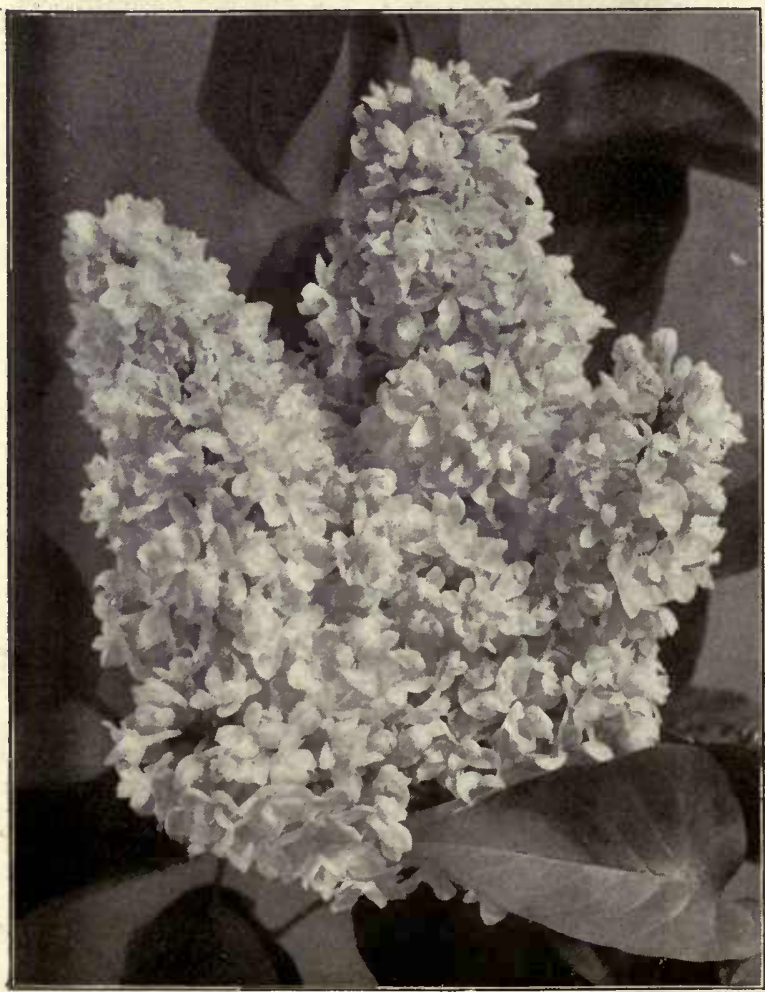

Mme. Lemoine Lilac.
LILAC, continued

S. villosa. An upright bush with pinkish white flowers after other Lilacs have passed.

Japanese. S. Japonica. A pyramidal tree resembling the Cherry. In July it has broad panicles of white flowers.

\section{LONICERA. See Upright Honeysuckle}

\section{MAGNOLIA}

The Magnolias growing as shrubs are native of eastern Asia, and blossom before the leaves appear, while those described under trees are mostly native of eastern United States, and bloom in June and July after the foliage has developed. As decorative plants they rank among the highest, coördinate with the Rhododendron anong evergreens, and the Rose and Orchid anong flowers. In early spring their velvety buds open into pearly white or pink chalices. They are worthy to be planted alone in front of the shrubbery, or if in groups should have room to develop their individual beauty in broad, rounded specinsens. We are growing large qualltities of Magnolias, believing that they should supplant the cheap effect of commoner plants.

M. Soulangeana. The most satisfactory variety for general planting. It flowers very abundantly in April. The blossoms are white, tinged with. pink at the outer base of the petals.

M. Lennei. Broad cup-shaped flowers, rose-purpleoutside and white on the inner surface of the petals.

M. purpurea. Deep red flowers in April, and occasionally during the summer.

M. stellata. Hall's Magnolia. The little gem of the family. Its flowers frequently open before the last flurry of snow has disappeared. The flowers differ from the others in opening into a rosette or starshape with numerous narrow white petals. The shrub grows in a compact dwarf form about 8 feet high.

\section{MAPLE, JAPANESE}

\section{Acer Japonicum}

These beautiful shrubs hold the same relation to others that the ferns do to the larger-leaved vegetation. The Japanese gardeners have developed from the one or two species a host of varieties, having delicate and gracefully arranged foliage that comprise our daintest and most exquisite slurubs. or small trees. They are especially adapted to gardens and lawns. Io to 15 feet.

A. palmatum ; syil., polymorphum. The nornal type, beautiful for the delicate shades of green and red in spring and autumn.

Blood-leaved. A. palmatum, var. atropurpureum. The foliage is a brilliant crimson, turning to purple during the summer. A vigorous grower. 
JAPANESE MAPLE, conlinued

Cut-leaved. A. palmatum, var. dissectum. The foliage is so finely divided as to resemble a delicate fern. It grows in graceful, wide-arching sprays 2 to 3 feet $\mathrm{high}$ and greater in width, being typically Japanese in its form. Its growth is slow, but it is well worth the necessary waiting.

Purple Cut-leaved. $A$. palmatum, var. dissectum purpureum. Resembles the above, except that the foliage is red and purple throughout the season.

\section{NEW JERSEY TEA}

\section{Ceanothus Americanus}

A small shrub covered with fleecy white flowers in July. It will grow in rocky and dry situations.

PEARL BUSH, See $\mathcal{E} x$ ochorda.

\section{PRIVET}

\section{Ligustrum}

Amoor. L. Amurensis. From the Amoor river in Manchuria. It comes from a climate very similar to our own and has proven perfectly hardy in the severest winter. It is an upright

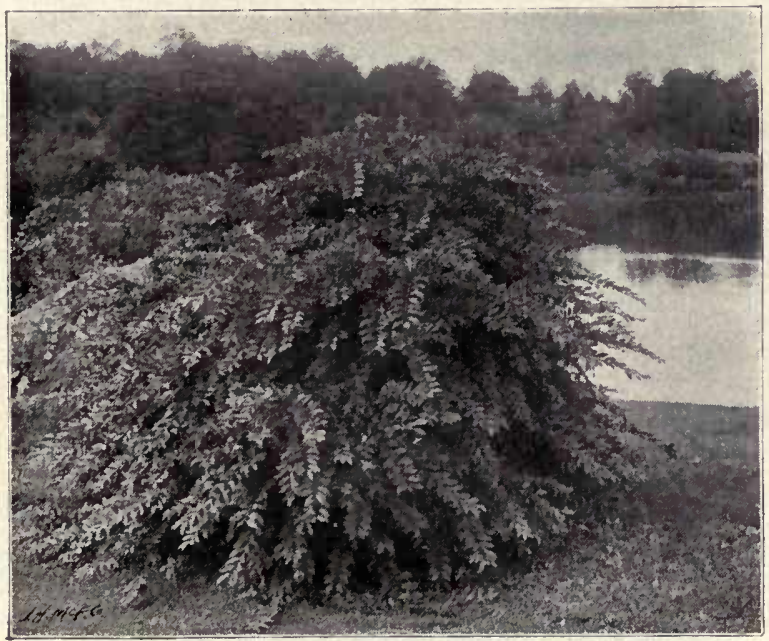

Prostrate Privet. Ligustrum regelianum. (See page :2.)

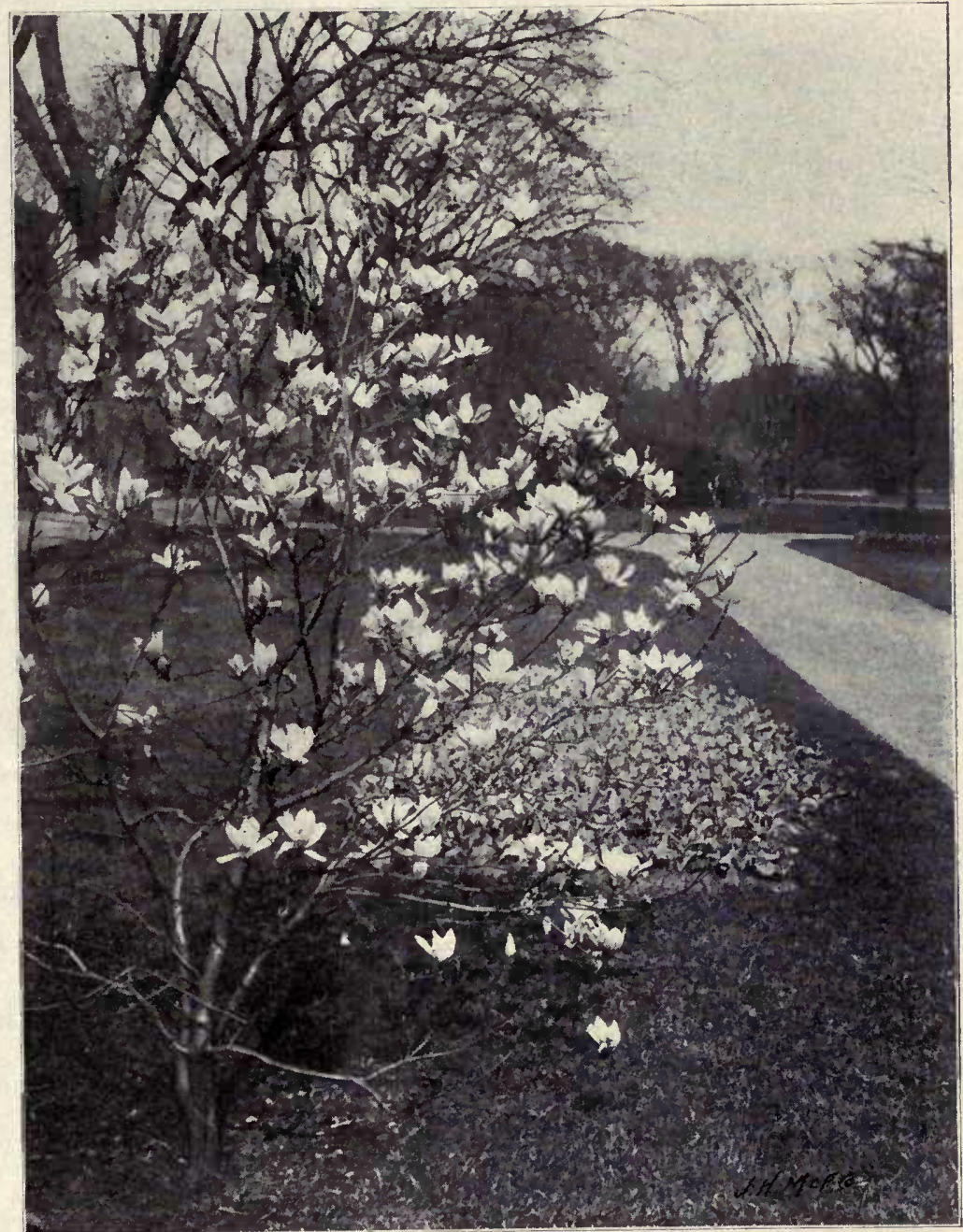

Magnolia Soulangeana. (See preceding page.)

AMOOR PRIVET, continued

shrub with lighter foliage and bark than the others. It should be largely used.

California. L. ovalifolium. The use of Privet as a hedge plant is well-nigh universal, taking the place of Arborvitæ, Osage Orange and other plants. Its one defect is the tendency to become thin at the base when not properly trimmed. We are developing a new method of growing to overcome this defect, producing plants with numerous stems at the base. These when planted 6 inches deeper make a thick base devoid of the three-cornered open spaces frequently seen. It is economical as a smaller number is required. In the after trimming it is advisable to keep the lower portion of the hedge wider than the top, so as to permit the sun to shine on and encourage the lower branches.

Privet is one of the best plants to use in exposed windy situations and where the salt spray flies, as the thick glossy leaves will remain uninjured and make luxuri- 


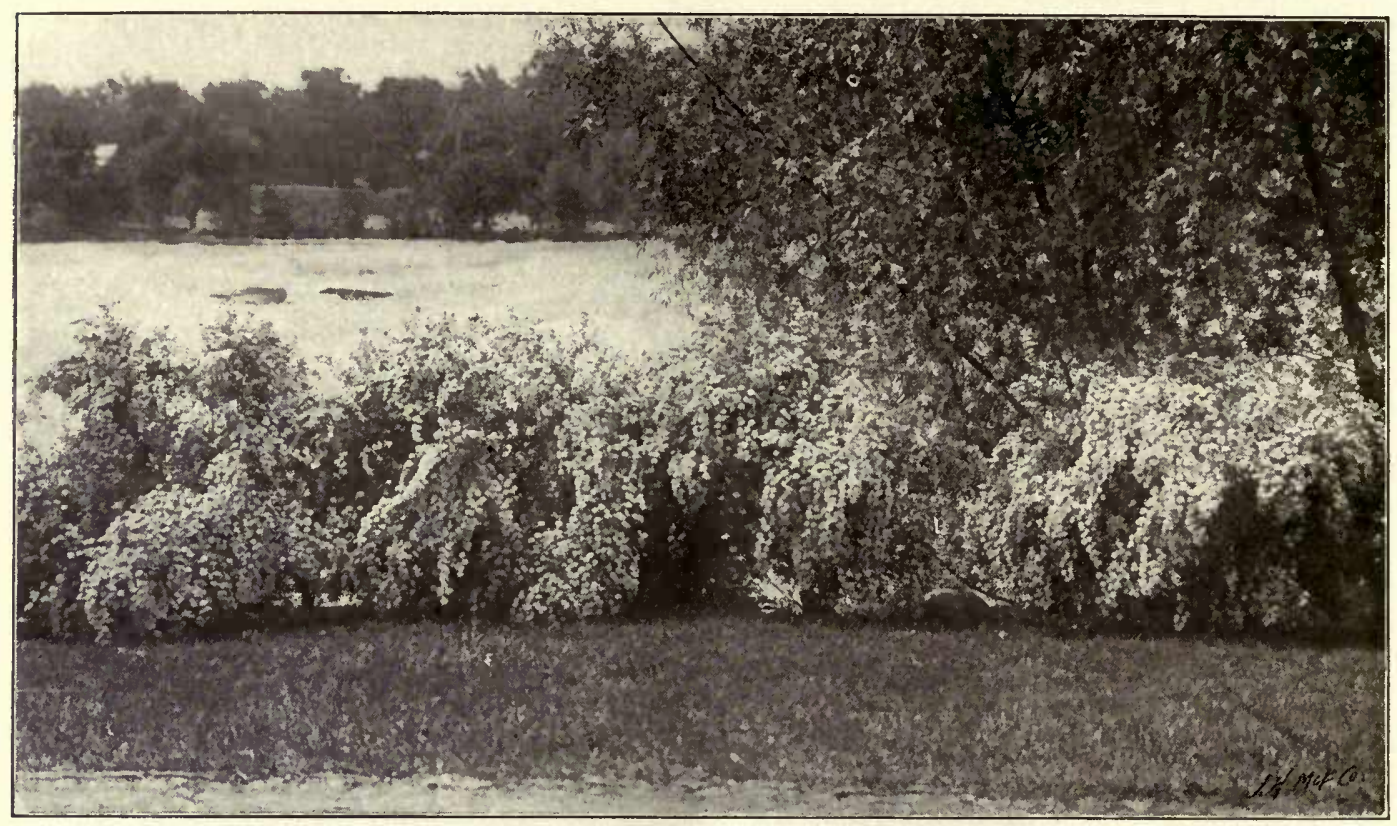

Pianting of Spirca Van Houttei on the bank of the Niagara River, N. Y.

\section{CALIFORNIA PRIVET, conlinued}

ant growth. It is also excellent for holding raw banks by binding the soil with its many roots. When not trimmed, it will attain a height of 20 feet, and is valuable for screens and windbreaks. On the other hand, it may be kept trimmed to 4 inches in height, when it develops small leaves, and makes a good substitute for dwarf box edging. It takes kindly to the severe trimming necessary for hedges, and is largely used for training in various forms of topiary art in formal and Italian gardens.

Dome-shaped, Standards and Arches of Privet. We offer carefully trained specimens in a broad dome-shape, 6 feet wide at the base. The Privet in standard or bay-tree form has round, symmetrical heads that are flat at the base. They are trained by a new machine of our invention which makes them as accurate as if turned by a lathe. These can befurnished for planting in the ground, or established in tubs and terra-cotta pots. For entrances, flower gardens or courts, we have arches 7 feet in lieight.

Ibota. I. Ibota. A tall, graceful shrub, holding its dark green leaves until midwinter.

Prostrate. L. Ibota, var. Regelianum. This has all the vigor and healthfulness of the California Privet. The branches grow out horizontally, arching gracefully downward, adapting it well for the border of shrubberies.

\section{RHODOTYPOS}

R. kerrioides. Of neat habit and graceful form. The large white flowers resemble the syringa.

\section{SIBERIAN PEA TREE Caragana arborescens}

A small tree characterized by its yellow peashaped flowers.

\section{SMOKE TREE (Mist Tree; Purple Fringe) Rhus cotinus}

An old-time shrub or small tree of irregular habit. In summer it is enveloped with a mass of fleecy purple bloom resembling smoke or mist.

\section{SNOWBALL (Viburnum)}

V. Opulus, var. sterile. A vigorous old-fashioned bush, having a profusion of white balls of flowers.

Japanese. $V$. tomentosum, var. plicatum. There is a dignity and strength of character about this shrub which makes it of importance even when not in flower, and its healthful foliage gives it first rank. The flowers are clear white, in balls about 3 inches in diameter.

Large-flowering, or Chinese. $V$. macrocephalum, var sterile. A very showy variety, with balls of flowers 7 to 8 inches across.

V. prunifolium. A native shrub or small tree; shining foliage and bright autumnal color.

\section{SPIREA}

Throughout the entire season some of the Spireas are sure to give a touch of color to the shrubbery. They should be extensively planted for their beauty and adaptability to various soils and climatic conditions. The varieties following are given in the order of blooming.

Thunberg's. S. Thunbergii. In early May the branches of this shrub are so thickly set with fine white flowers that it appears like a snowcovered evergreen. During the summer its foliage makes a distinct contrast with its neighbors. The graceful willow-like sprays of leaves arching to the ground present a billowy, fluffy mass, useful in rounding off groups of shrublery. In autumn it turns to brilliant yellow and red. 3 to 4 feet. 


\section{SPIREA, continued}

Bridal Wreath. S. prunifolia, var. flore pleno. Blooming just after the last, its appearance is quite distinct, from its tall, upright habit. The tiny double white flowers are thickly clustered along a stiff stem before the leaves appear. The summer foliage is a glossy green that turns to orange and red in the fall.

S. Van Houttei. The most beautiful of the Spireas. It grows to 6 feet in height, and the graceful branches, weighed down with a wealth of white blossoms, curve till they touch the ground. It comes into bloom just before Decoration Day.

S. Reevesi ; syn., S. Cantoniensis, var. flore pleno. Similar to the above, but slightly tender.

Golden. Physocarpus opulifolius; syn., S. opulifolia, var. aurea. Nine-Bark. A coarse, tall shrub with yellowish green foliage.

S. Billardii. Its spikes of pink flowers contribute a bit of col $r$ to the shrubbery in July and August. Having a somewhat ragged appearance, it is best planted back of other shrubs.

S. Bumalda. A low, flat-topped shrub with pink flowers.

Anthony Waterer. A recent introduction that is worthy the high favor it has attained. It grows from I to 3 feet high, and is most useful as border, or for planting against the foundation of the house. Throughout the summer and autumn it is covered with brilliant crinson flowers.

\section{SUMACH. Rhus}

The Sumachs always make an attractive feature of the landscape, as nature has massed them on rocky hillsides and along dry roadways. The foliage is dark and rich in summer, and in early autumn changes to brilliant red. In some species the bright red fruit is retained all winter.

Smooth. R. glabra. A shrub 3 to to feet high with smooth stems, rich foliage and large bunches of red berries. One of the best for planting.

Cut-leaved. R. glabra, var. laciniata. The leaves are finely divided and have a fern-like appearance.

Staghorn. R. typhina. This grows to a small tree, or it may be kept cut back, when it will produce long vigorous foliage of a tropical appearance. The stems are velvety. Its coarse growth precludes its use on small places.

Shining. R. copallina. We often find this species growing on sterile sand-banks. It is more compact than the other Sumachs, with rich summer and autumn foliage. It is especially good to use in quantity in shrubberies and wild planting.

R. semialata, var. Osbeckii. A vigorous Japanese tree with large panicles of yellow flowers in July and August. In autumn it has brilliant orange and red foliage.

\section{SWEET-SCENTED SHRUB Calycanthus floridus}

An old-time favorite with chocolate-colored flowers, having a delicate and lasting fragrance.

\section{SWEET PEPPER-BUSH Clethra alnifolia}

A native slirub of good foliage, bearing spikes of fragrant white flowers in July. It grows in damp places, and may be planted on upland.

\section{SYRINGA (Mock Orange) Philadelphus}

The common name of this shrub is the same as the botanic name of the lilac. The Syringa is one of the tallest shrubs, shooting up long, vigorous branches to I2 feet, which the following year are bent over with their burden of blossoms. The white flowers are an inch and a half in diameter and fragrant. Syringas are valuable for tall screens.

\section{TAMARISK. Tamarix}

In appearance, this is a cluster of frail wands of light, filmy foliage, and the plumes of tiny flowers look like a pink cloud. It gr.,ws rapidly and should be planted on seashore lawns, as it is native in such situations, and thrives in salt spray.

\section{VIBURNUM, See Snolvball.}

\section{WEIGELA. Dierbilla}

Whether standing alone or grouped in large masses, the Weigelas are always satisfactory. They are vigorous, broad shrubs, 5 to 8 feet high, producing such a wealth of bright flowers in carly summer as to be indispensable. In Prospect Park, in the Vale of Cashmere, the Weigelas have been most happily used. Flowering at the same time a: the Rhododendrons, they harmoniously extend the color effect at a distance. There are white, pin?: and red varieties. Eva Rathke is a new variely with brilliant red flowers.

\section{W I T C H - HA Z E L Hamamelis Virginiana}

The last of all the flowers of the year. In October, when the leaves are falling, its narrow petaled flowers are scattered along the bare branches. At the same time the seeds, which are larger than buckshot, are fired for 20 feet from the stout seedpods.

\section{WILLOW. Salix}

The Willow family contains several members that may be grown as shrubs. Owing to their rapid growth they produce the desired result in onc or two seasons, after which they should be annually pruned. In plantations at the seaside, and shelter-belts, the Willow shrubs should form a good proportion. See, also, description under trees.

Laurel-leaved. S. pentandra. A sprightly, quickgrowing bush with bright glossy leaves.

Yellow-barked. S. vitellina.

Red-barked. S. vitellina, var. Britzensis. This and tne above variety grow 6 to ro feet per year. They are useful in shrubberies, and their bright bark gives a touch of color in the winter.

S. multinervis. This is a low, spreading shrub of silvery foliage, having soft gray flowers or pussywillows in February. From Japan.

\section{YELLOW ROOT Xanthorrhiza apiifolia}

A cover plant that is useful under the shade of trees and shrubs and in the woods. It is $I$ to 2 feet in height and has a dense foliage that turns to brilliant yellow and orange in the fall. It is planted by thousands as a cover in large parks and estates. 


\section{Broad-Leabed Ebergreen Shrubs}

\section{HOLLY, RHODODENDRON, LAUREL, BOXWOOD, YUCCA, ETC.}

This class contains the gems of outdoor plants. Many lawns need the richness which they alone can give. They are erroneously considered the most difficult to grow because of the many expensive failures. Success will follow the application of the principles explained in this catalogue on pages 57 and 58 , Rhododendrons.

\section{ANDROMEDA. Pieris}

A. Japonica. P. Japonica. Bell-shaped flowers of chaste and delicate beauty hang in gracefully drooping racemes, 6 to Io inches long, resembling lily-of-the-valley in March or early April. The flower-clusters are prepared in the fall, and it needs wrapping with straw during the winter.

\section{AZALEA}

A. amœna. Lovely Azalea. In early May this is a mass of rosy purple flowers. The habit of the plant slightly resembles the Boxwood, the leaves being similar in size. It is best to give it a sheltered position from severe winds, and protect in winter.

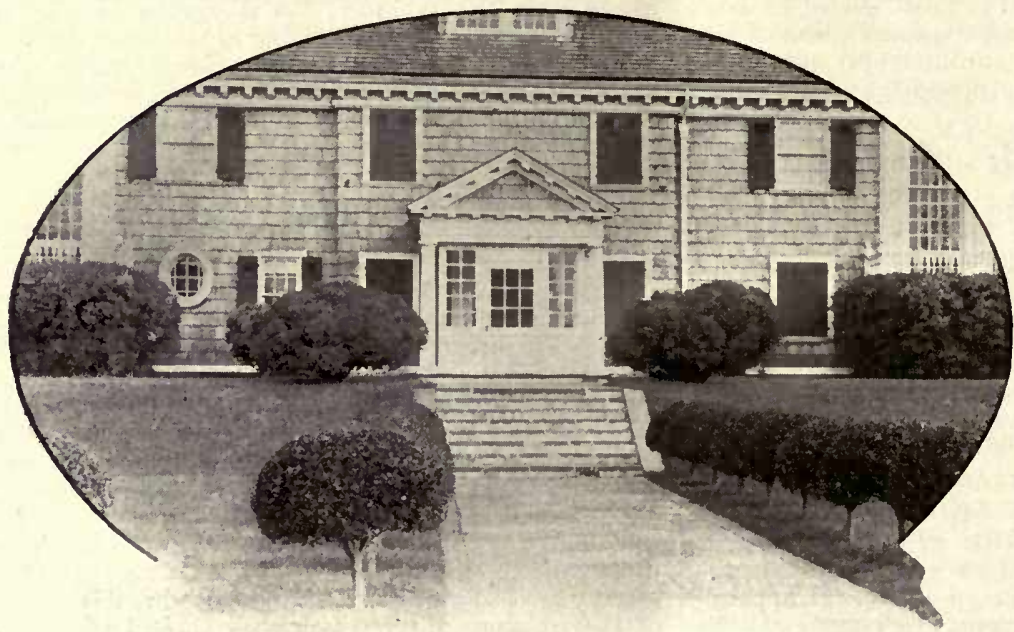

The large dwarf Boxwood trees flanking the entrance were moved by our Evergreen Tree-Mover, and are very old. 'The rows of Standard Privet on either side of the path are in keeping with the general scheme of decoration. "Wheatlands," the residence of Mr. E. D. Morgan.

\section{BOXWOOD. Buxus}

We have a large and varied collection of Boxwood, ranging from dwarf box edging to the old and well-developed specimens 75 years old. In moving several hundred of these large plants we have had success with all sizes. Some specimens have been 125 years old and I4 feet broad.

Boxwood is wild under the forests of England. A study of the chart of climate will explain why the best old Boxwoods are to be found about the old farm and village homes that are not far above the water level, as along the shores of Long Island and near the ponds. It is the Dwarf Boxwood that was planted by the early Dutch and English settlers from New England to Virginia. We offer to send a crew of expert men and appliances to move old Boxwood or pack it for safe shipment.

Tree Box. B. sempervirens. We offer this in large quantities, 6 to $\mathbf{I 2}$ inches high, for borders and grouping with other evergreens next to house foundations. For formal planting we have specimens trained to broad domes, 2 feet wide, by a device of our invention that enables us to train them as accurately as with a lathe. They have deep, wide root systems adapted to local conditions. Pyranids 2 to 3 feet.

Narrow-leaved Box. B. sempervirens, var. angustifolia. A variety with compact dark foliage.

There are other varieties with golden and silver variegations.

Dwarf Box. $B$. sempervirens, var. suffruticosa. This is the form found in old gardens. Its slow growth accounts for its compact and even velvety texture. Protection is advisable in open places for the first few winters, as the bark is liable to split. For edging, we offer plants grown from layers with a deep root-system, and therefore less liable to winter-kill.

To repair old borders we offer compact sections 6 to I 5 inches high. As a substitute for Box edging, California or Dwarf' Chinese Privet, Myrtle and English Ivy, may be used.

\section{DAPHNE}

D. Cneorum. A narrow-leaved alpine resembling the trailing arbutus in habit, and exceeding it in perfume. The heads of bright pink flowers are scattered from May till October.

\section{EUONYMUS}

E. Japonicus. An upright shrub with very glossy evergreen leaves. In a shaded protected place it will grow 6 feet high. There are several variegated varieties. It is a native of southern Japan.

E. radicans. This clinging vine is destined to become widely used as a low shrub and ground cover. Left to itself it trails over the ground, or the stems cling to each other, making a pyramid 2 feet high. The bright green leaves are about 


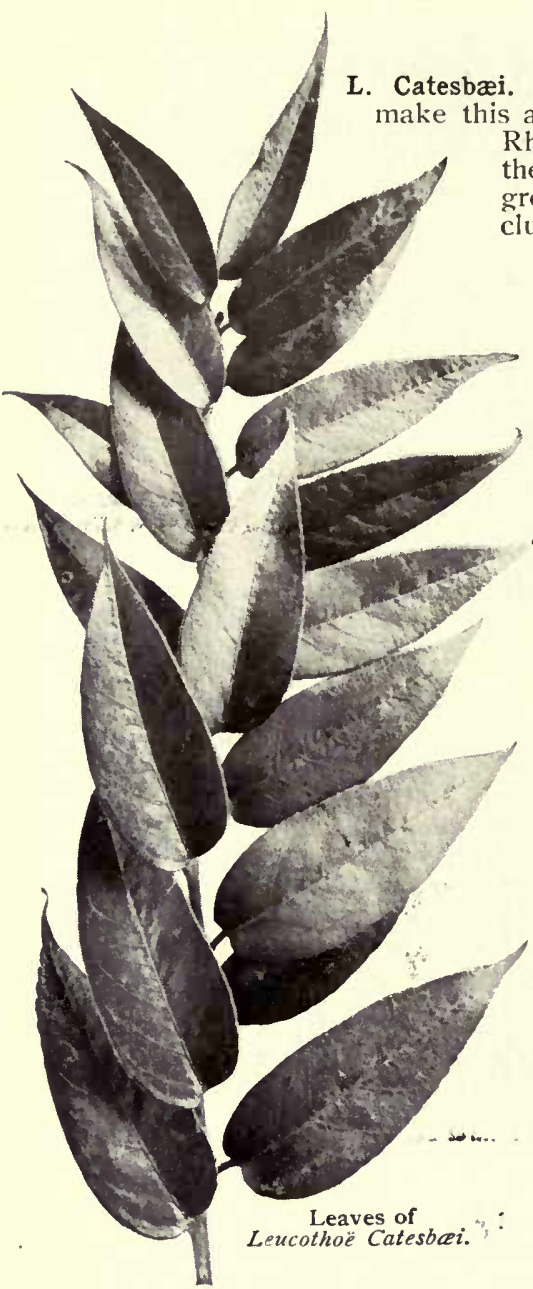

\section{LEUCOTHOё. Andromeda}

L. Catesbæi. A. Catesbai. The long, arching sprays of dark glossy leaves a beautiful decorative plant. The pointed leaves are larger than Rhododendron leaves, and, in the sun, turn claret color in winter; in the shade it remains green. It should be used as a ground cover to group with Rhododendrons, and to cut with holly for decoration. The clusters of lily-of-the-valley-like flowers appear in May. Hardy.

\section{MAHONIA. Berberis}

Shrubs 2 to 5 feet high with holly-like foliage, and yellow flowers in May. They may be used as cover plants in moist, shady situations. If planted in the open they die back occasionally in winter.

M. aquifolium. B. aquifolium. Oregon Grape. The glossy leaves. are 8 inches long, divided into leaflets resembling Holly. It is unique and attractive in autumn and early winter, as the outer leaves change to bronze and purple.

M. Japonica. B. Japonica. A sturdy and striking plant worthy of wider culture. The strong, erect stems standing 3 to 5 feet high bear leaves a foot long, with leaflets much larger and thicker than Holly, keeping their green color in winter.

B. ilicifolia. Native to Terra-del-Fuego, this indicates another little-explored region at the tip of South America, from which plants should be introduced. It has simple spiny leaves, green till midwinter. 3 feet.

\section{TRAILING MYRTLE (Periwinkle) \\ Vinca minor}

The many thousands of this trailing vine we have sold in the past few years attest its recurring popularity as a cover plant. It forms a deep green, compact ground cover, either in the open or in the deep shade under Pines and Spruce trees. The close mat, 5 inches deep, ispleasant to walk upon. It will keep the leaves from

blowing out from under Rhododendrons. It will hold steep terrace banks sloping in any direction. For wild gardens and bordering drives in the woods it is unexcelled. As a border for flower beds it keeps as green as Boxwood. Its bright blue flowers appear with the first violets.

Variegated. V. minor, var. aurea variegata. A brightly variegated carpet.

Double-flowering. $\quad V$. minor, var. plena. A pretty variety with double purple flowers scattered through the summer.

White-flowering. $V$. minor, var. alba. Pure white flowers.

\section{RHODODENDRON}

The dignified rich green foliage and the magnificent flowers of the Rhododendron are the most beautiful element of decorative landscape. The universally admired results in English parks can be attained here by planting tall specimens of Rhododendron maximum with borders of the brighter colored hardy hybrids. The culture is simple and success certain.

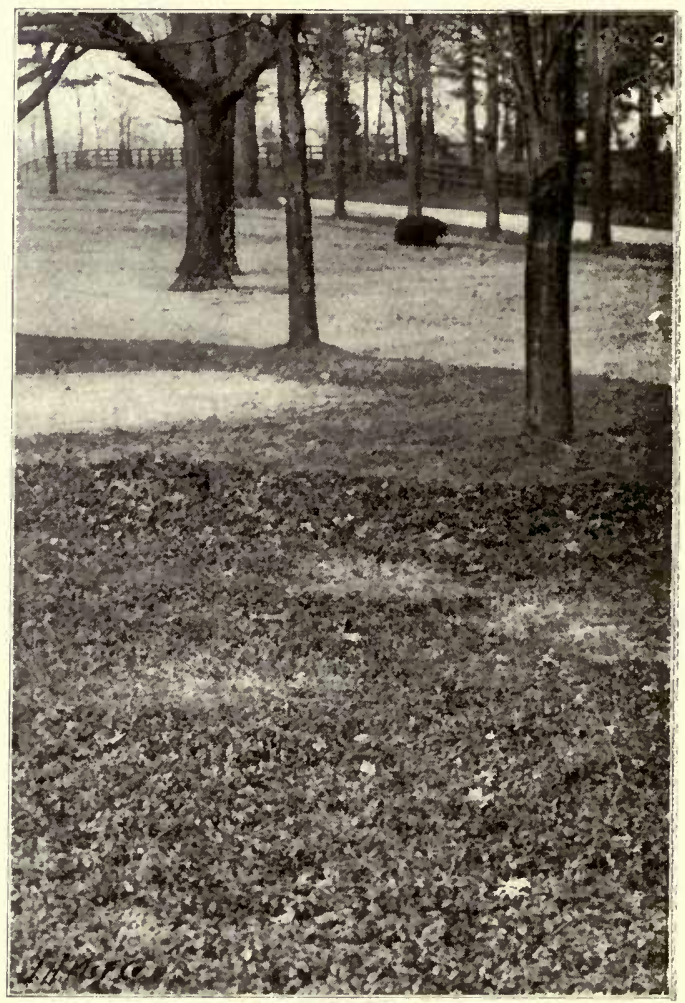




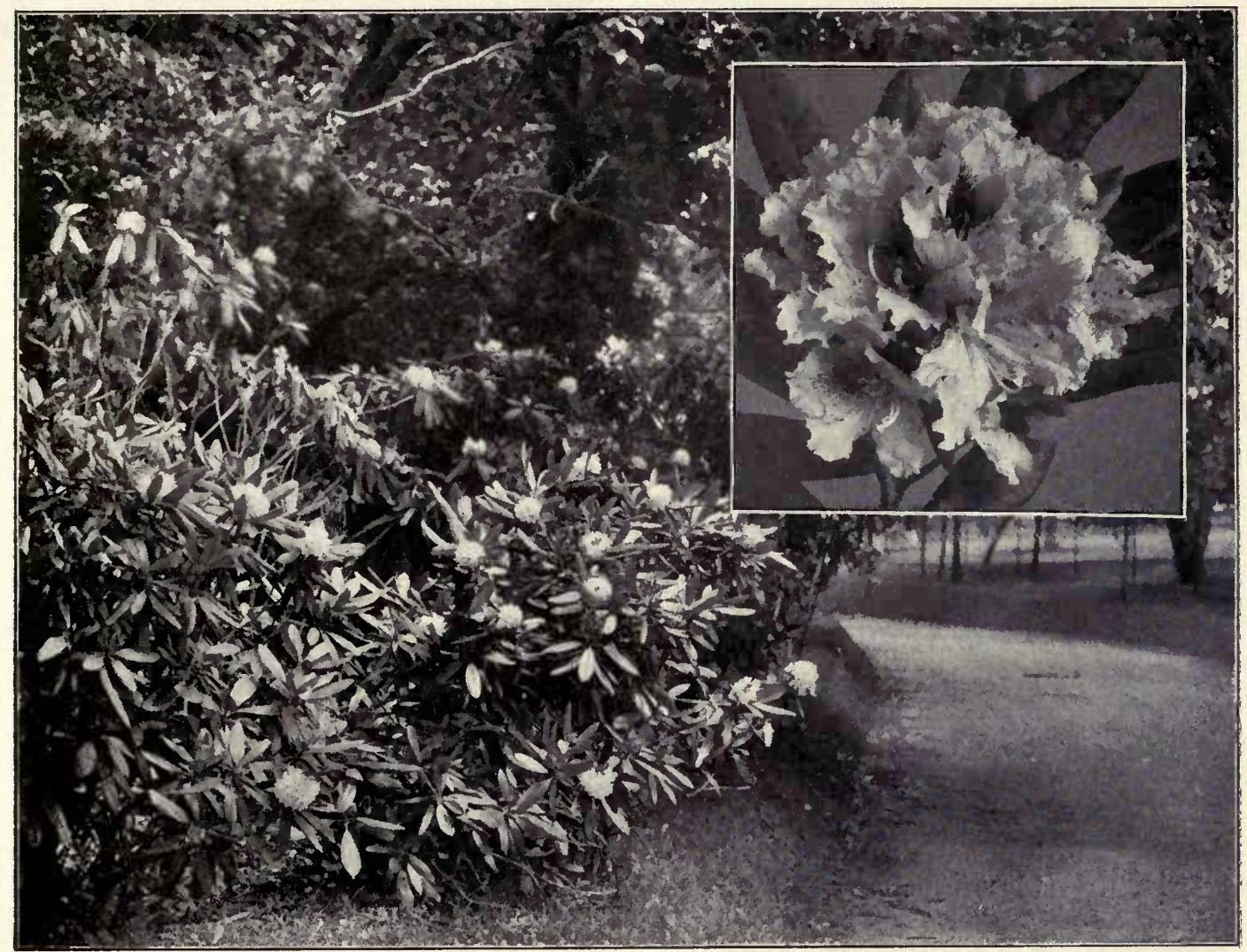

Rhododendron maximum in mass planting on the edge of a woodland drive at "Castlegould." The large flower is the bloom of Rhododendron Catawbiense.

SorL. -Loam, or loam well mixed with one-fourth to one-third leaf-mold or well-rotted manure. Soil 2 feet deep is preferable. Avoid clay, limestone and stagnant moisture, which are rare on Long Island.

Light.-Partial shade, at least in winter, as on a north slope, north of buildings, or by trees such as Oak and Locust. Avoid Silver Maple and trees that rob. They set most flower-buds in the open.

Culture. - Mulch annually with Io inches of rotted manure and leaves. This keeps the soil cool, moist and unfrozen in winter and provides humus, which the minute rootlets can penetrate. Water thoroughly once a week in a long drought if necessary. Remove seed-pods in July.

Exposure.-Shelter from drying winter winds by planting in masses and by a windbreak of evergreen or deciduous trees, or a temporary winter fence. A good protection from both sun and wind is afforded by evergreen boughs or straw. Well-established hardy varieties may be open to view all the year.

These conditions are favorable to all of the Ericaceæ family, as Azalea, Laurel, Trailing Arbutus, Andromeda and many other woodland plants, as Ferns, Orchids, Lilies, etc. The cliart of soil and climate, on pages 6 to 16 , shows why Long Island is favorable to the culture of Rhododendron Catazbiense, the hybrids in which it predominates and $R$. maximum. They are accustomed to 40 degrees annual range of temperature between the average of July and January. It shows the reason of the general failure here of Rhododendron Ponticum and similar species and hybrids from Armenia, the levant, Sikkim and Nepaul, regions having only 20 degrees annual range. The latter thrive in England, Holland, France, and are the most easily propagated. The surplus is sent to this country and adorns. the sidewalk plant market The first to bloom is worth the price, but for permanent lawn planting they lead to disgust with Rhododendrons. An expert can generally separate hardy and tender varieties. Some of the points are; hardy Catawbiense hybricls-leaves oval, rounded at each end, glaucous beneath, leaf-stem and bark of twigs yellowish; tender Ponticum and hybrids-leaves elliptical, generally narrower and more pointed than the Catawbiense, pale green beneath, leaf-stem and bark of twigs generally green or purplish.

\section{ACCLIMATING}

To acclimate imported plants, get hardy varieties. They are scarce, slowly propagated and substitutes often sent. Soak the balls, loosen the surface, plant a little deeper to get the plant to make its own roots above the Ponticum stock. Shade and water for the first year. Pick off flower-buds as they expand. Our plants have been through this acclimating from two to six years: When imported the plants have small balls; they exhaust themselves by blooning and the roots may not push out of the ball, 
RHODODENDRON, con. which hardens in our drier climate. They suffer drought, especially if not mulched, and clo not ripen the wood for the next winter, and thus may gradually fail.

R. maximum. This species is native of valleys and swamps from Georgia to Nova Scotia. It has long, glossy leaves and beautiful pink and white flowers in June and July, continuing the season much later than the others. We have planted many hundreds with entire success, for bordering drives in woodland, for planting in shady corners of the house, or making rich banks of green in the

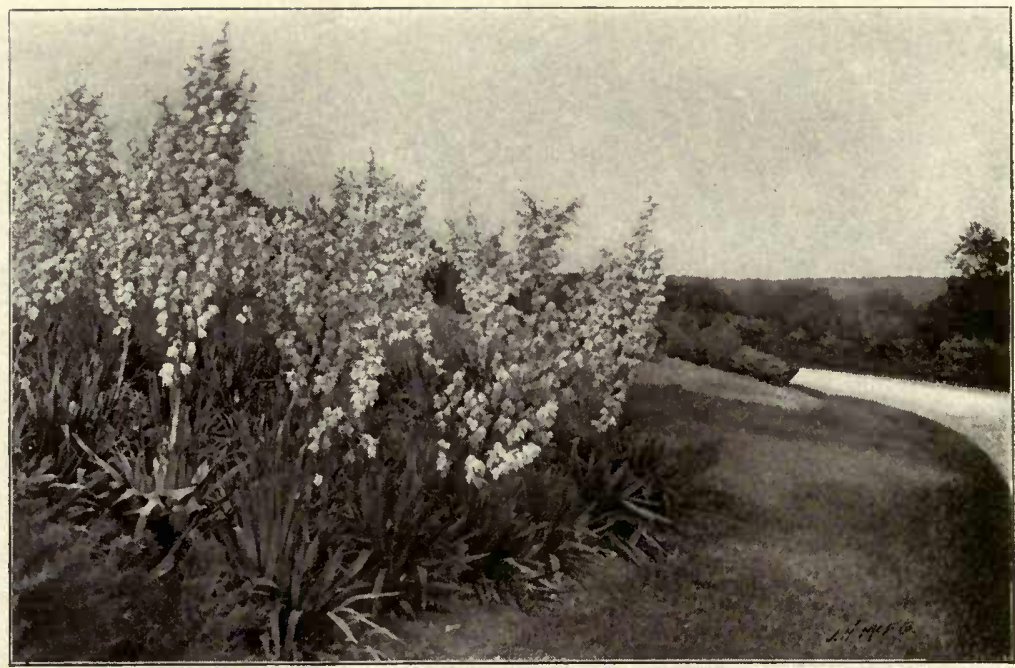

A planting of Yucca upon the estate of the late Hon. W. C. Whitney.

open. Growing in the partial shade of our orchard are many large e tablished clumps 5 to 9 feet high. We can furnish it in car-load lots at low rates.

R. punctatum. A pretty dwarf species, with small leaves and pink flowers, blooming before the others.

R. Catawbiense. Flowers in June. Bright redpurple. This species is native of the higher peaks of the Alleghany Mountains, Virginia to Georgia, where zero weather, high winds, bright sun and dryness are often its lot, but with leafmold soil it survives.

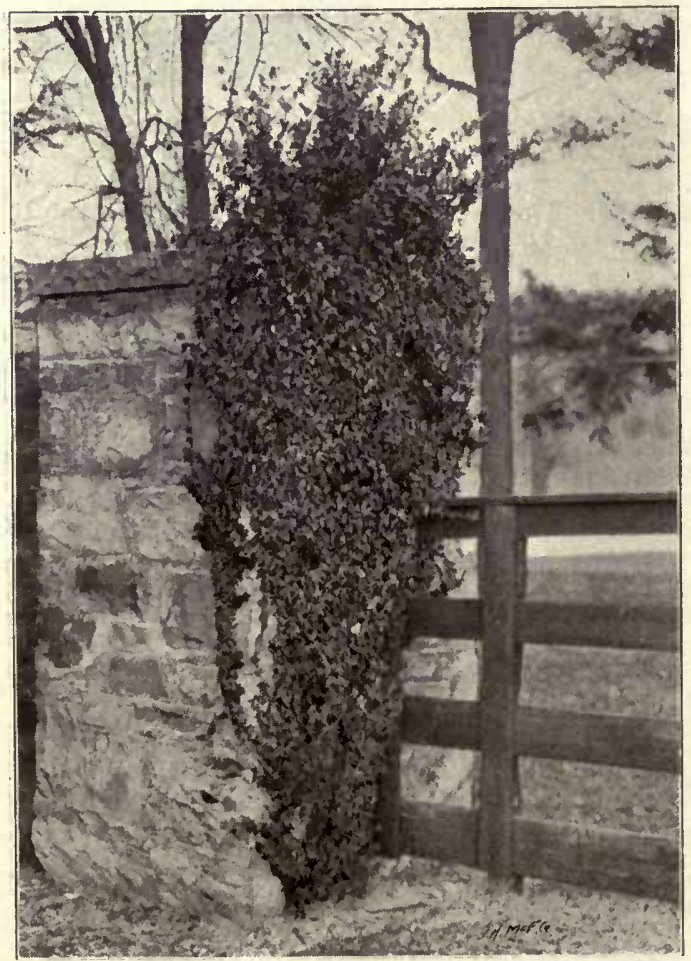

Euonymus radicans growing on stone pillar at Wheatley Hills.

\section{Named Varieties of Catawbiense Hybrids of Tested Hardiness}

Gloriosa. Very large bunch of blush white flowers. Everestianum. This has long been the standard of hardiness. The plant is low and broad, as if it grew up near the snow line. Flowers rosy lilac, spotted and fringed.

President Lincoln. Rose color.

Caractacus. Crimson.

Lady Claremont. Rosy scarlet; blotched petals.

Album elegans. White. A tall, upright form which should be in the center of groups.

\section{THORN (Evergreen Hawthorn)}

Pyracantha coccinea; syn., Crataegus Pyracantha

An evergreen thorny shrub, growing 6 feet high. and bearing clusters of orange fruit. The small leaves are bronze in winter.

\section{YUCCA}

Y. filamentosa. Bear Grass; Spanish Bayonet; Adam's Needle. This stately garden flower has found a new use. It will cover dry, sterile gravel and sand banks, or grow near the beach. We sell it by the thousand at low rates for these purposes. It is native to dry hills from Virginia south, but is perfectly hardy here. The tropical foliage is 2 to 3 feet long, and maintains its green color all winter. It resembles and is related to the century plant. The lily-like flowers appear in July on stems 4 to 7 feet high.

\section{Vines}

\section{AKEBIA}

A. quinata. A vigorous Japanese climber that is adapted for quickly covering piazzas, arbors, wind-mill towers and rough ground. It is a clean attractive vine with nearly evergreen leaves, and inconspicuous fragrant brown flowers in May.

\section{BITTER SWEET. Celastrus scandens}

The bright orange and red berries make this native climber attractive in autumn and winter. 


\section{CLEMATIS}

C. Jackmani. A slender vine, having large deep violet-purple flowers. An abundant bloomer.

C. paniculata. This vine has rapidly gained popularity by its vigorous healthy growth, and its clouds of white flowers in August. The shrubbery at that time has but few flowers, and an occasional Clematis clambering over the top will look as beautiful as the Spirea Van Honttei in its season. It will transform an ugly fence into a beautiful hedge.

\section{DUTCHMAN'S PIPE Aristolochia Sipho}

A strong, showy vine with leaves Io inches wide. The small green blossoms are in the shape of a pipe.

\section{EUONYMUS}

E. radicans. A valuable cliniber that may be considered a substitute for English ivy in this country, having the advantage over it of keeping the foliage uninjured by our bright winter sunshine. It grows on walls and trees, sending out horizontal branches in the manner of an old English Ivy. It makes a good evergreen ground cover, and is useful in covering stones and stumps in rock gardens. The glossy dark leaves are about an inch long by a half inch wide. See, also, under Broadleaved Evergreens. It has escaped and runs wild in our woods.

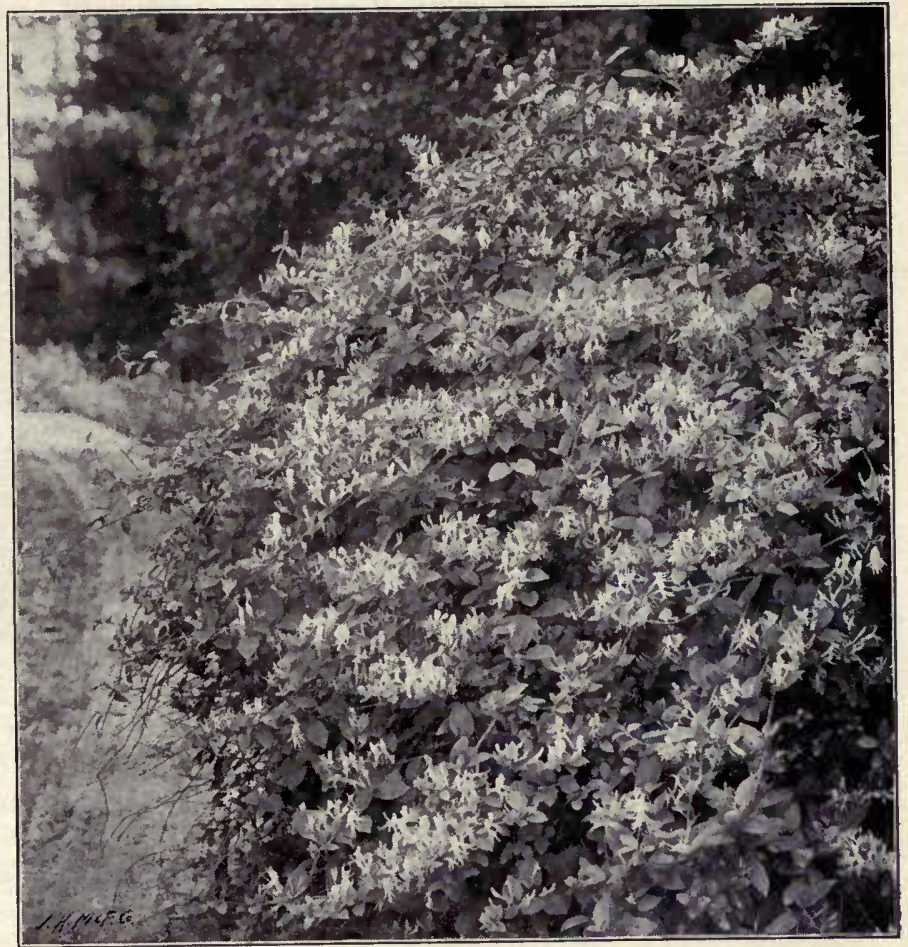

Japanese Honeysuckle at Dosoris.

\section{HONEYSUCKLE. Lonicera}

This large family contains a variety of useful vines. They are all hardy and vigorous in their growth and not at all particular as to soil or moisture.

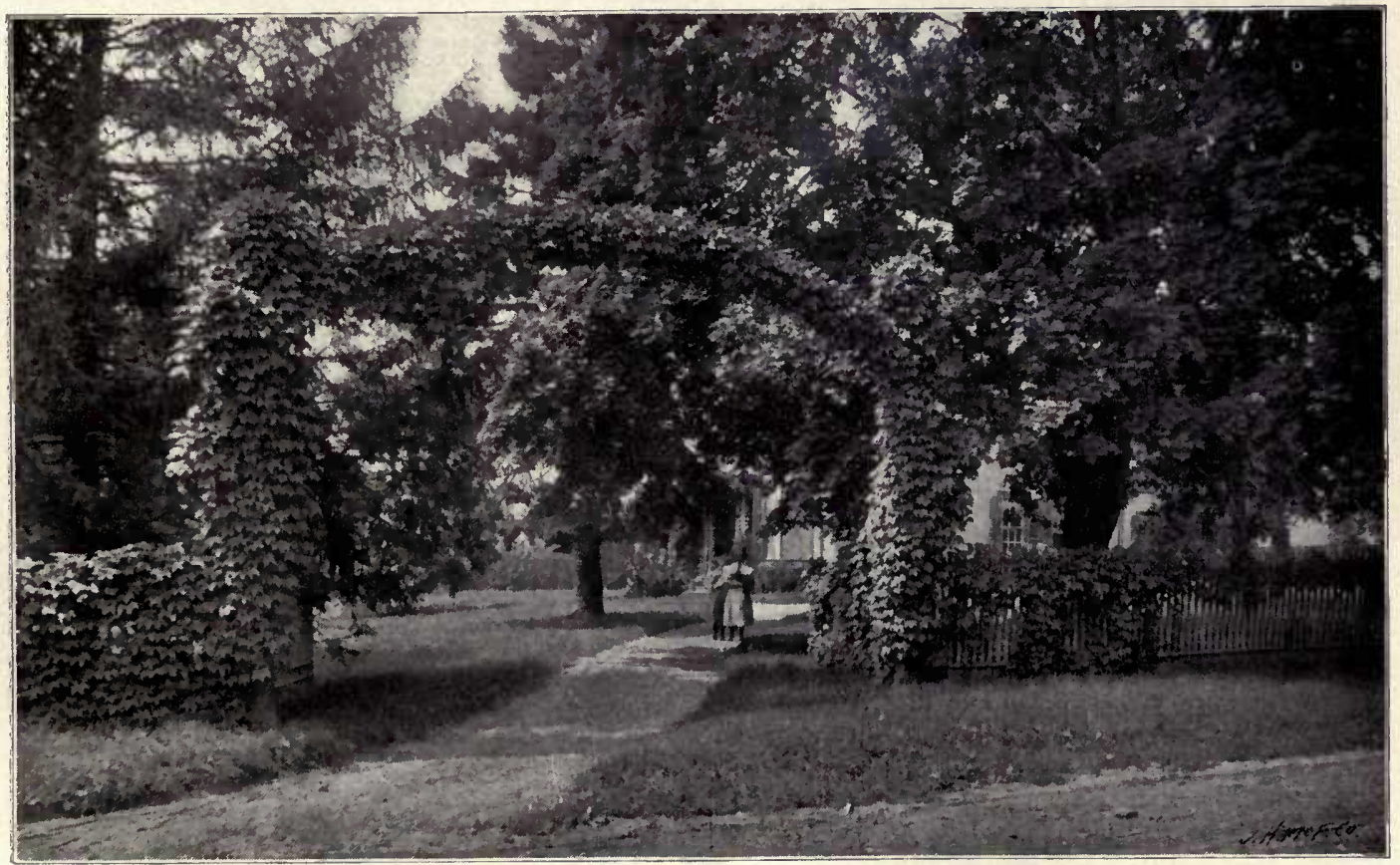




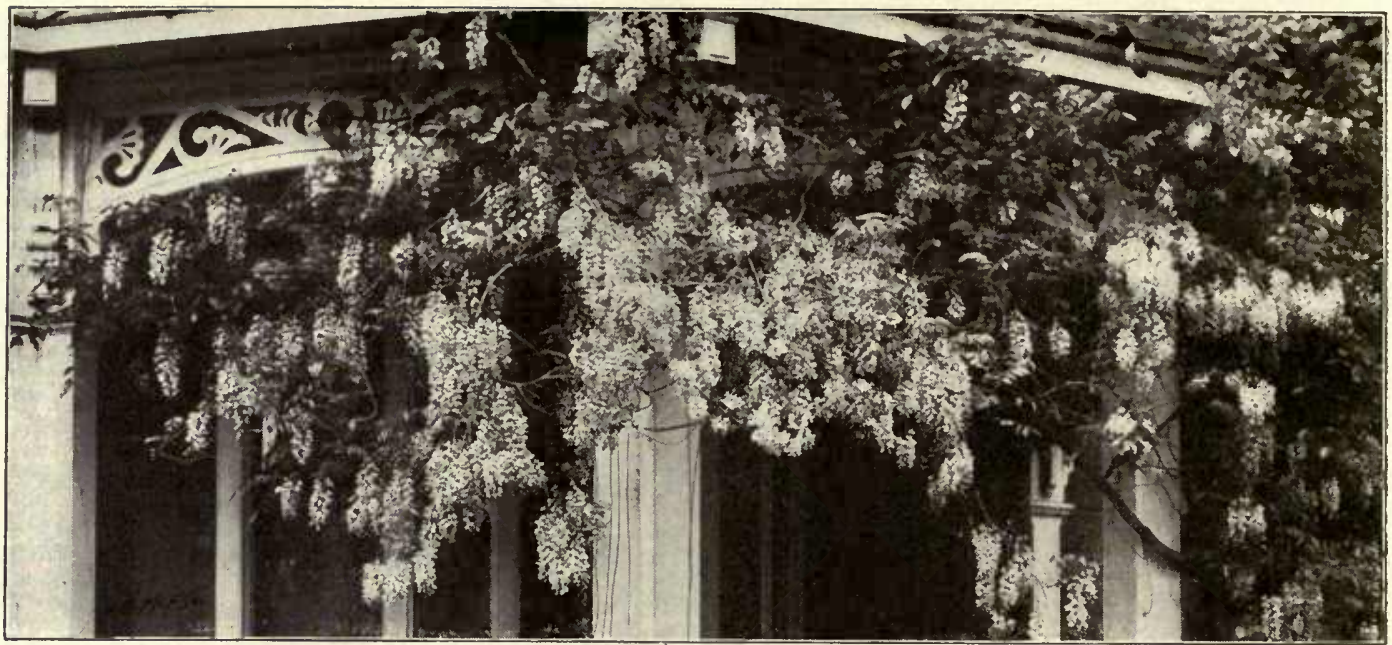

Chinese Wistaria on a porch. It is far more beautiful when clambering over a tree. (See opposite page.)

\section{HONEYSUCKLE, continued}

Japanese. L. Japonica. Hall's Honeysuckle. Leaves dark green, and are held throughout most of the winter. The fragrant white and yellow flowers appear in early summer and again in autumn. It is a strong, rapid grower, and makes a most satisfactory vine for porch, pergola, hedge or ground cover. For covering rough banks along the roadside, sandy bluffs, stumps and rocks, or for holding up embankments, it has no equal. Trained to a slight wire fence and trimmed, it thickens up its masses of rich foliage and forms a beautiful hedge. We offer it at low rates per thousand for these purposes. We also offer long vines for immediately covering walls or porches.

Golden. L. Japonica, var. aurea reticulata. A striking object, with its leaves brilliantly marked with yellow and red.

Chinese. L. Japonica, var. Chinensis. Similar to the Japanese, with dark leaves, purple beneath.

Coral Trumpet. L. sempervirens. A climber, with long, tubular scarlet flowers during the summer.

L. Heckrotti. A low climber that is chiefly valuable from the profusion with which it flowers in October, and if in a sheltered place, it affords the rare opportunity of gathering flowers in November and December.

\section{IVY}

English. Hedera Helix. English Ivy is the ideal evergreen vine for clinging to stone and brick walls when the soil and climatic conditions are congenial, as in England. There are beautiful plants of it on Long Island, growing 5o feet high and sending out branches i 2 feet wide, where protected from severe cold and brilliant winter sunshine. It makes a rich, dark border to garden paths. Its shade-enduring properties make it valuable for covering the ground and trumks of trees in woodland borders.

Japanese, or Boston. Ampelopsis "tricuspidata; syn., A. Veitchii. The most popular of the clinging vines. It maintains its glossy and healthy foliage even in the dust and smoke of large cities, and thrives where there is apparently little soil to feed upon. It will cling to stone, brick and wood, but it will not twine upon wires or trellises. The brilliant autumn coloring is one of its attractive features. (See page 59.)

\section{JESSAMINE. Jasminum nudiflorum}

As grown here at its northern limit, this is more properly a shrub to be planted in a warm and protected corner of the house, where it will bloom in earliest spring. It will frequently open its blossonis on a sunny day in winter. The graceful sprays of yellow flowers closely resemble the Forsythia.

\section{KUDSU VINE}

\section{Dolichos Japonicus; syn., Pueraria Thunbergiana}

A vine exceeding all others in rapidity of growth, sometimes reaching 40 feet in height in a season. It dies back to about io feet from the ground every winter in this latitude. Useful for quickly covering unsightly objects.

\section{ROSES, CLIMBING}

$$
\text { (Sec, also, Roses) }
$$

Roses should not be omitted from any general problem requiring the use of vines. Rosa Setigera and some of the new varieties, such as Wichuraiana, or Memorial Rose, and its hybrids are particularly valuable because of their persistence, healthy foliage and rapid growth.

\section{TRUMPET CREEPER. Tecoma}

T. radicans; syn., Bignonia radicans. Trumpet Vine. In late summer this vine is decorative with its clusters of orange-crimson trumpets 4 or 5 inches long. It clings closely to walls and trees, sometimes having a trunk 8 inches in diameter, and reaching to the top of locust trees 75 feet high. The foliage is glossy and healthy in all situations. We offer it in quantity for decorating fences, locust groves and woodland borders.

T. grandiflora ; syn., B. Chinensis. Chinese Trumpet Creeper. A species not so hardy as the last, but it will become established with slight protection. It may be grown on a low post or stake in the shrubbery, where it is very decorative with its wide scarlet trumpets. It is much more showy than the last and continues blooming later in the summer. It is appropriately planted by fences and tree-trunks. 


\section{VIRGINIA CREEPER (Woodbine) Ampelopsis quinquefolia}

The Virginia Creeper transforms some of our woodlands, especially groves of locust, into waving pillars of red foliage as a forerunner of the autumn change. As a vine for porches and summerhouses, it possesses the valuable feature of being rather open in growth, permitting the breeze to pass through, especially if it receives an anmual pruning after the manner of its nearest relative, the grape-vine. It will cling to the bark of tree trunks, and the variety Engelmanni will cling to stone walls. It will thrive on the beach, even where washed over by high tides.

\section{WISTARIA. Kraunhia}

A genus of tall, twining vines, which maintain their health and vigor in dry and sterile soil. Even in the city, and with other unfavorable conditions,
WISTARIA, continued

the foliage is good. When Wistaria is trained in the form of a low tree, or standard, with a straight stem, and a wide-branching head, it is particularly beautiful at blooming tine with its hanging masses of blue flowers.

Chinese. $\quad H$. Chinensis. This is the common form that blooms profusely in May.

Japanese, or Loose-clustered. $W$. multijuga. A rare Japanese species with racemes of flowers $2 \frac{1}{2}$ to 3 feet long. In Japan, it is planted to grow over the bridges in the tea gardens, where its deep violet fluwers are objects of great admiration.

W. magnifica. $I V$. speciosa, var. magnifica. A vigorous vine, with racemes 6 to 8 inches long, borne in June after the others have passed.

White. $\quad I$. Chinensis, var. alba flora. A variety with white flowers.

\section{Hardy Roses}

The short list of Roses we offer includes those varieties that are most popular because of their benuty and hardiness in this climate. If a greater variety is desired, we will procure them. The hybrid perpetuals bloom abundantly in June and occasionally during the summer and fall.

Anne de Diesbach. Carmine. A large, beautiful and fragrant Rose. Plant vigorous.

Earon de Bonstetten. Velvety maroon. One of the richest dark Roses.

Baroness Rothschild. Delicate pink. Large full flowers, growing close against the smooth, light green leaves. Very choice and beautiful. Not fragrant.

Francois Levet. Cherry-red. A valuable Rose from its strong growth and free blooming habit.

General Jacqueminot. Brilliant crimson. This is perhaps the most popular Rose. A vigorous plant with abundant large, fragrant blooms.

Hermosa. Bright rose-pink. One of the best bedding Roses that blooms constantly from June till October. A small, compact plant.

Jules Margottin. Carmine-rose. This grows to be a bush 5 to 6 feet high, and wide, with luxuriant foliage and abundant blossoms.

Madame Gabriet Luizet. Silvery pink. A beautiful Rose. Slightly fragrant.

Madame Plantier. Pure white. Foliage and stem light green. This makes a large bush that is useful for hedges or for nassing in shrubbery. The white blossoms are borme in large clusters.

Magna Charta. Pink, suffused with carmine. The flowers are large and fragrant, borne on strong, light green stens.

Margaret Dickson. White. This Rose resembles Baroness Rothschild in its form and the close setting of leaves about the flowers. The large white blossoms with pale flesh center are very beautiful. Fragrant.

Paul Neyron. Rose-pink. The largest of the Roses. The stems are strong and smooth, and the foliage is a bright light green. A free bloomer. A valuable exhibition variety.

Princess Adelaide. Moss Rose. Delicate rose-color. The buds are well covered with moss, and the foliage is dart-
Persian Yellow. A thorny bush with delicate foliage, bearing a profusion of small bright yellow Roses clustered thickly along the branches. A favorite in old-time gardens. Very hardy.

Harrison's Yellow. A deeper yellow than the preceding. A free bloomer.

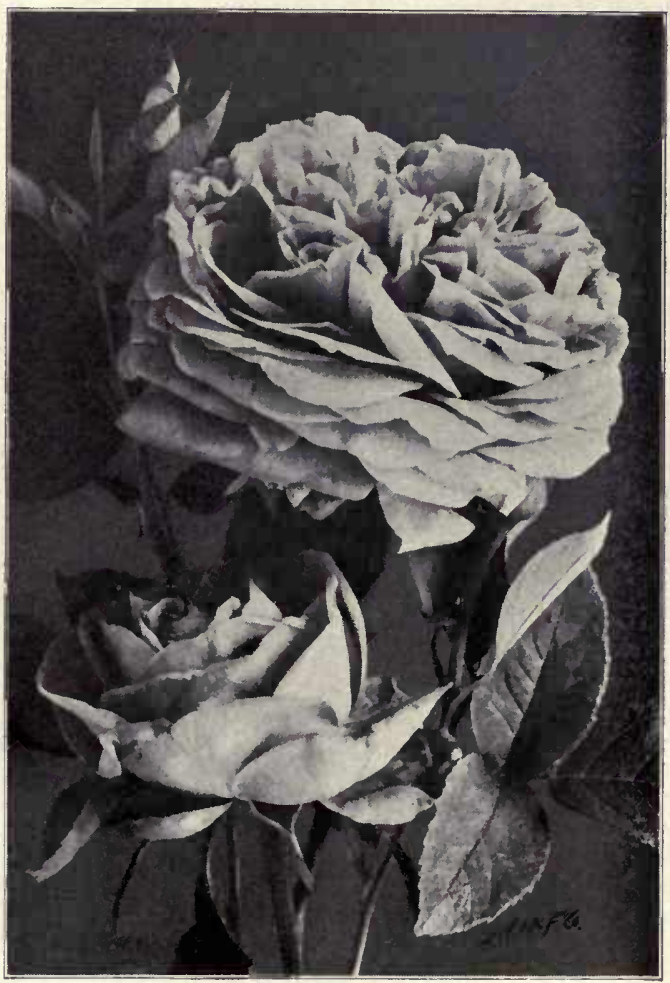

Paul Neyron. 


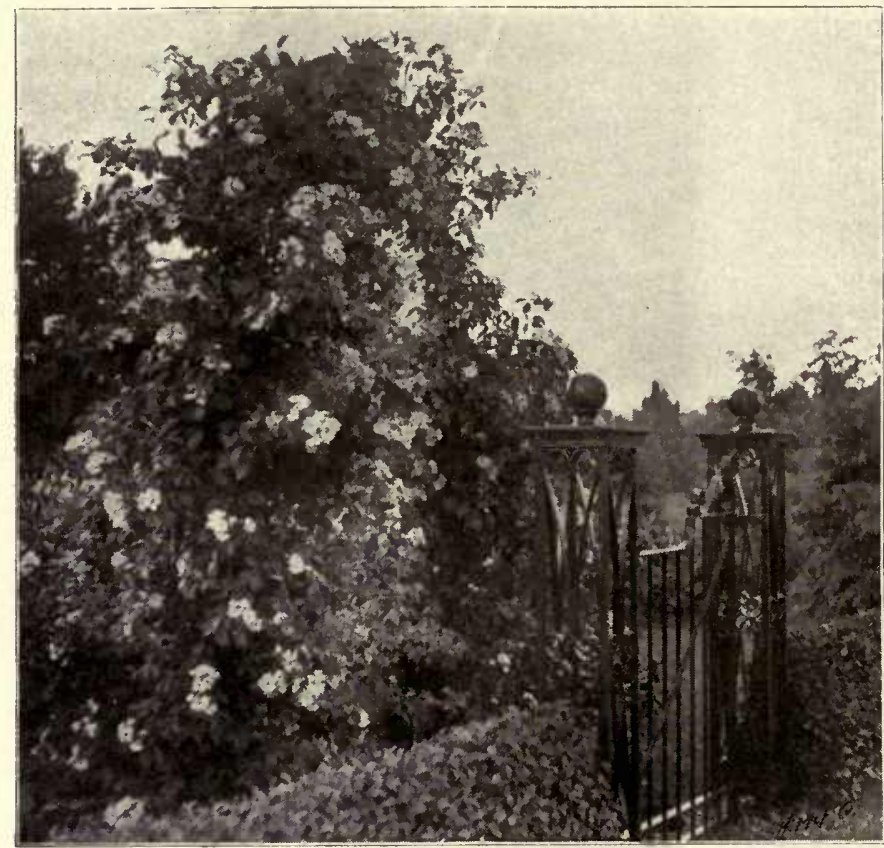

Arch of Prairie Rose at Red Spring, Glen Cove.
ROSA RUGOSA, conlinued

succeeded after the failure of many other kinds of foliage, due to the caustic action of the salt air, has led to its general use for seaside planting. It is a most desirable shrub for groups and hedges. The thick, shining foliage is free from insect and mildew attacks. Large, single, rose-pink flowers borne in clusters during the summer are followed in autumn by large, bright red hips resembling crab-apples. IVe offer this at low rates by the hundred, for hedges, seaside and cover planting.

R. rugosa alba. Single white flowers.

Belle Poitevine. Foliage like the species and large double rose flowers.

Blanc Double de Coubert. A valuable acquisition to this race, for it combines the foliage of the species, with a pure white double flower 4 to 5 inches in diameter.

\section{PRAIRIE ROSES}

Baltimore Belle. White. One of the most attractive and satisfactory of the old-fashioned climbing Roses. A strong plant bearing large clusters of white flowers and delicate pink buds.

Queen of the Prairies. A companion to the above, with large, bright rose-colored blossoms.

Setigera. This is the parent of Baltimore Belle and Queen of the Prairies. It is a rampant grower, with luxuriant foliage and clusters of single bright pink blossoms in July. It is effective planted among large shrubs. On a pergola or trellis, to form the background of a flower garden, it makes a solid bank of Roses, I5 feet high.

\section{CRIMSON RAMBLER}

This Rose has becone one of the most popular of recent introductions. It will send up shoots ro to I5 feet in a summer, the side branches of which are weighed down with immense clusters of blossoms. These are semi-double, of the brightest crimson color and remain fresh for a long time. The foliage is a rich glossy green.

\section{ROSA RUGOSA Japanese Rose}

This species has introduced a new type into American horticulture, and, like many of its compatriots from Japan, grows with the greatest luxuriance and vigor. Its extensive use at Newport, where it

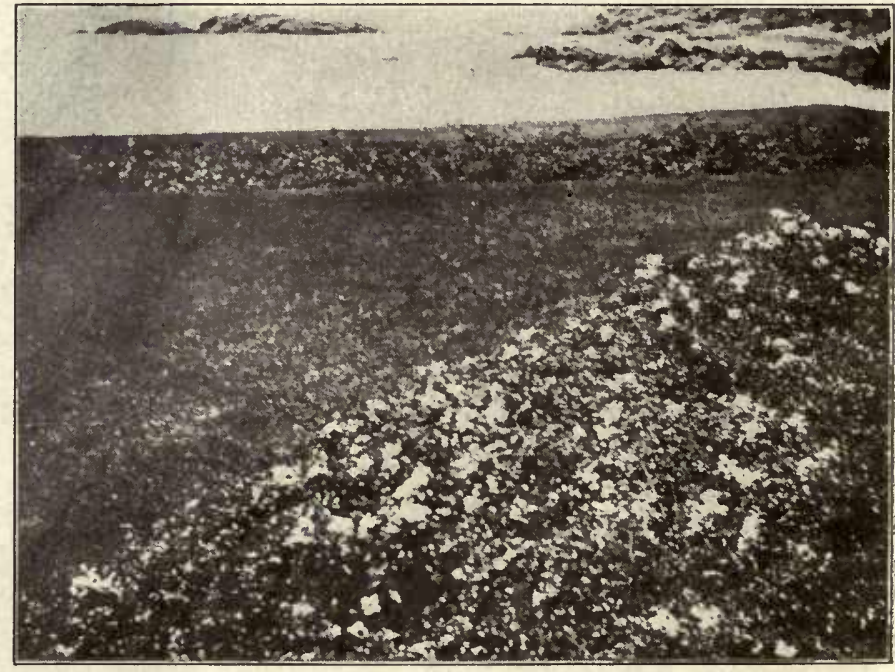

Rosa Wichuraiana on the rocks at Nahant, where it is deluged with salt spray.

Madame Georges Bruant. This is a hybrid of Rosa rugosa. The long-pointed buds are creamy white and as delicately beautiful as a Tea Rose. It flowers freely in June and later in the summer. The foliage is slightly liable to mildew in danı weather.

\section{SWEETBRIER. Rosa rubiginosa}

English Sweetbrier, or Eglantine, is an old-time favorite, with a profusion of delicate pink blossoms. The tender new shoots have a spicy fragrance that perfumes the air in damp weather. It is perfectly hardy, and very vigorous in growth. A good hedge plant. 


\section{MEMORIAL ROSE}

\section{Rosa Wichuraiana}

\section{TRAILING ROSE FROM JAPAN}

A nearly evergreen plant that trails along the ground, taking root and forming a thick mat. It is strong and vigorous and often grows 15 to 20 feet in a season. The thick lustrous foliage makes a rich background for the clusters of single creamy white tea-scented blossoms that come in July, after most of the Roses are past, and the rose-bugs are gone. It will grow on dry, poor soil, exposed situations, and at the seaside. It is a splendid carpet plant to cover banks, rocks, or under taller shrubs. It may also be trained up as a climbing Rose. There are a number of hybrids of this Rose that are distinct and beautiful.

Evergreen Gem. Rich bronzy green foliage remaining on all winter. Double flowers 2 to 3 inches in diameter, yellow in the bud, nearly white when open.

Gardenia. The flowers of this beautiful Rose are bright yellow, opening cream color, 3 to $3 \frac{1}{2}$ inches in diameter. A free bloomer and fragrant.

Jersey Beauty. Large, single, pale yellow flowers in profusion. Fragrant.

Manda's Triumph. Double white flowers in large clusters. Luxuriant foliage.

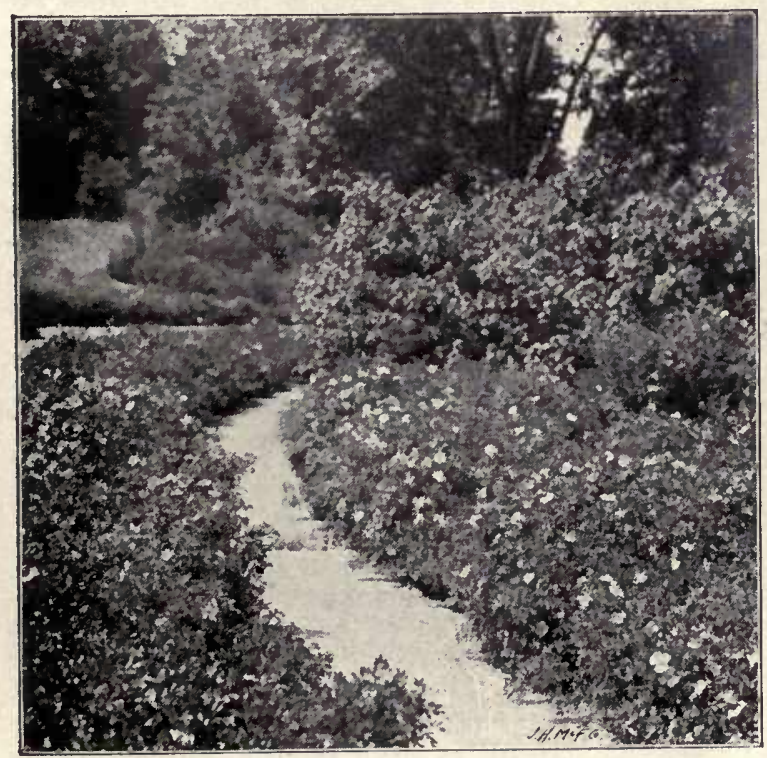

Wild Roses used as a ground cover on the borders of a path and drive in Arnold Arboretum, Boston.

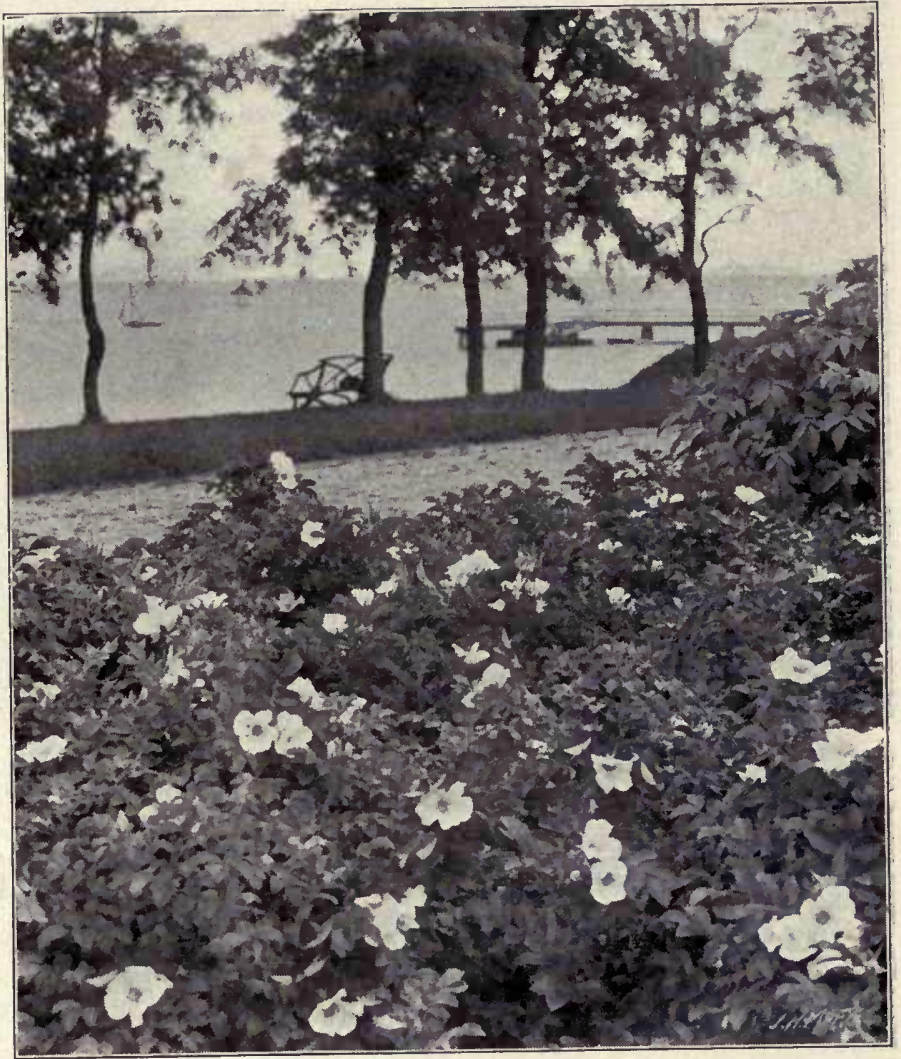

Rosa Rugosa growing where salt spray damages some other shrubs.

Pink Roamer. Bright pink, fragrant, single flowers. in close clusters.

South Orange Perfection. Small double blossoms. in great profusion. Blush pink, changing to white.

Universal Favorite. Rose-colored double flowers, about 2 inches in diameter. A rampant grower.

\section{WILD ROSE (Rosa lucida)}

This native wild Rose grows as a shrub. to 6 feet in height, but it is most effectively used when planted thickly, as in the accompanying illustration, and kept down to 2 feet in height. Prepare the ground thoroughly and set the little plants I foot apart. They will grow rapidly and form a dense mass of handsome glossy foliage, giving a profusion of bright pink flowers. When they become too crowded, dig up the whole bed, separate the plants, replant again all desired there and the rest elsewhere. The winter color of the masses of brown stems and red hips is very beautiful wherever used. It is a shrub which should be planted in large masses, and as such is a most attractive and appropriate covering for all manner of rough embankments and wild corners where there is no passing, or none desired, as its prickles. make it an effective barrier. It is a valuable plant for seaside use, as it will grow well under adverse conditions. 


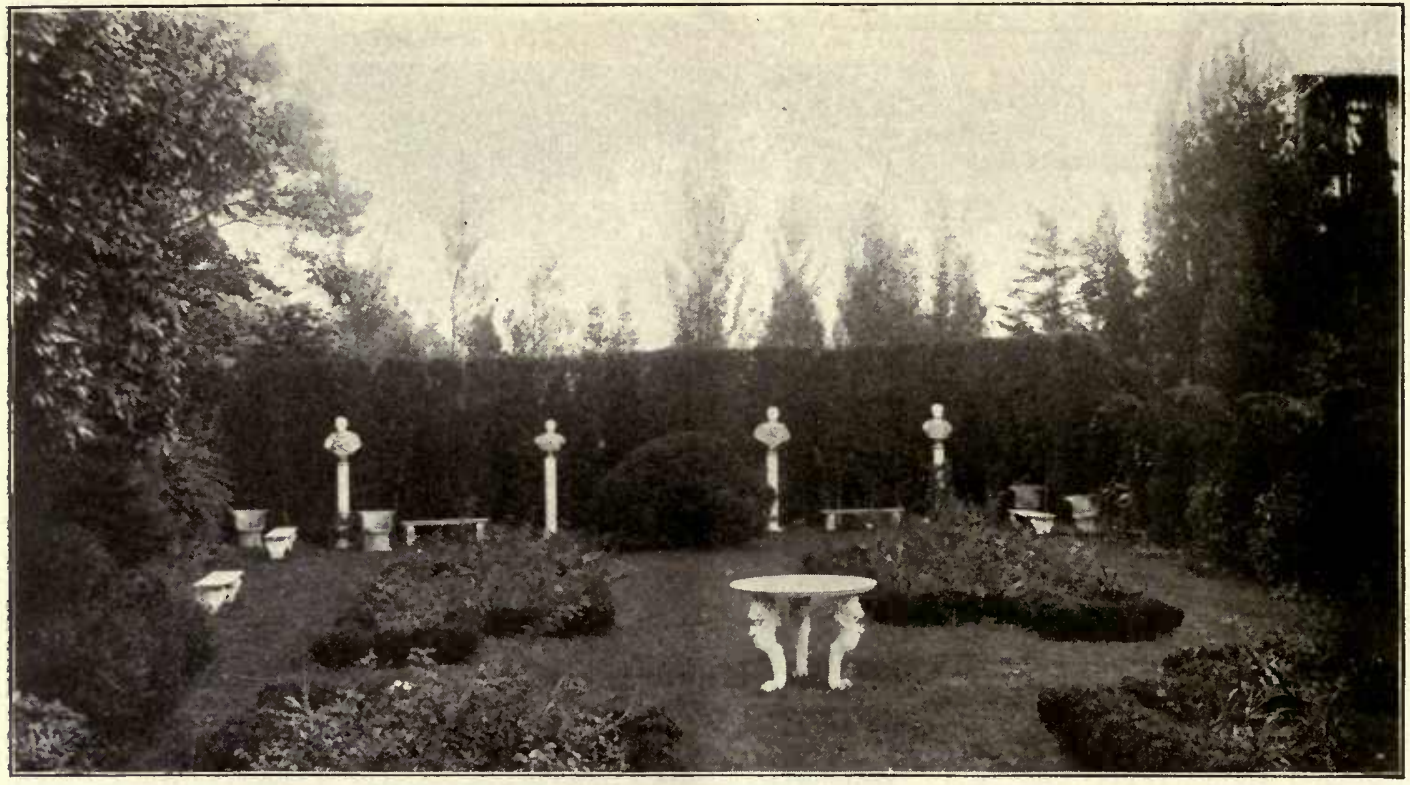

An immedlate result by the nse of the Hicks Evergreen Tree-Mover.--Italian winter garden formed by evergreen hedges. At the right are evergreen arches backed by groups of Silver Fir and other evergreens 25 to 30 feet high, making a sheltered nook for the children on windy winter days. "Roslyn House," the residence of Mr. Stanley Mortimer.

\section{Formal Garden Material}

One of the main reasons why the formal gardens of Italy, France and England are especially beautiful is because the native trees of the country have been used in the development of their designs.

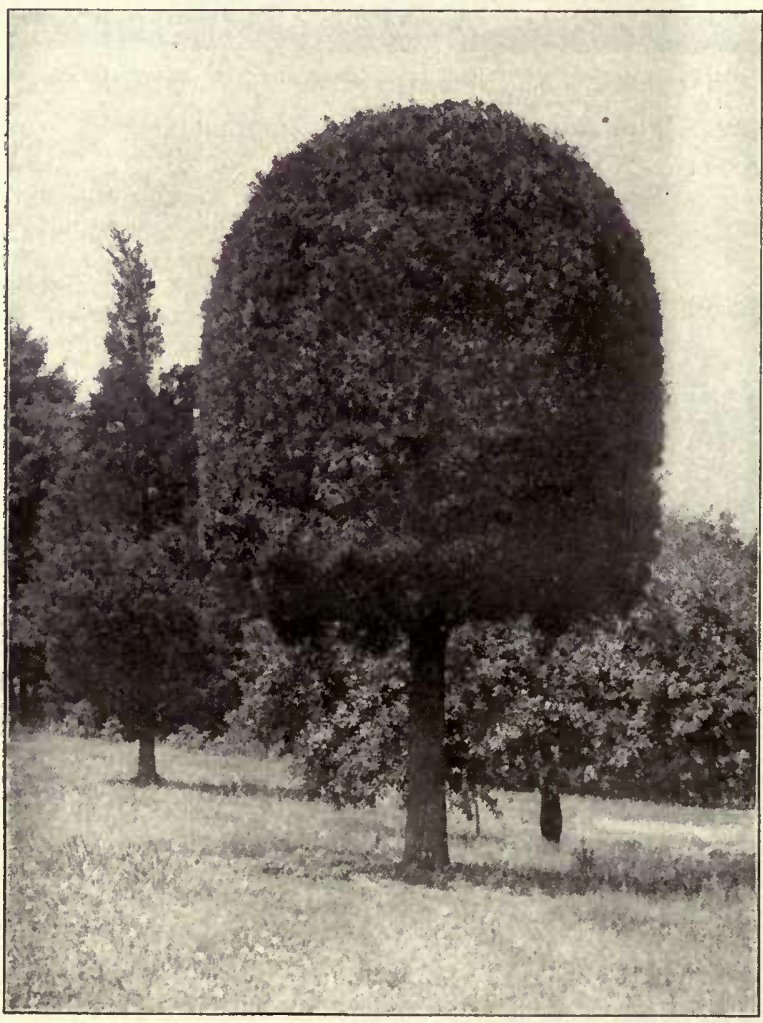

Une uf a pair oi standards trained to be moved to a terrace on top of the bluff at Port Washington. Height 2I feet, spread 15 feet, diameter of stem 12 inches. An interior frame of our invention liolds the form through wind and ice storms.
Extravagant and humiliating failures frequently result from trying to attain similar effects here with the same species used there. Gardens planted with these tender, imported trained trees are pleasing for a time, but nature takes its revenge; the English Yew gets ragged and brown, the English Holly dies and some others look unhappy. The trouble simply is that the trees are imported from the wrong climate. Our Soil and Climate Chart gives general localities producing flora hardy here.

We have trained trees adapted to this climate for the various purposes of formal gardens. Many of these large trees are prepared for moving on tree-movers. This is the only way to obtain trees in scale with large gardens.

\section{STANDARD, or BAY TREE FORM TREES}

\section{PRIVET}

We offer 100 with heads 3 and 4 feet wide, stems $3,4,5$ and 6 feet. Heads as symmetrical as if turned by a lathe and flat on the base. (See illustrations on pages 23 and 65.)

\section{CATALPA BUNGEI}

Heads $21 / 2$ to 6 feet wide, symmetrically pruned and dense; stems $2 \frac{1}{2}$ to 4 inches in diameter; 3 to 7 feet high. (See page 23.) 
STANDARD, or BAY-TREE-FORM TREES, continued

RED CEDAR. Heads 2 feet wide, stems 4 feet. Trees from this size up to heads 15 feet in dianieter can be supplied.

BOXWOOD. Heads I to 2 feet wide, stems $I \frac{1}{2}$ feet.

NORWAY MAPLE. A rare form with globose heads 8,15 and 30 feet wide ; 20 to 30 feet high; stems 5 feet.

\section{DOMES}

These are all trained by a machine of our own invention. They exceed all others in symmetry and density.

BOXW00D. Broad, low hemispheres or domes. They have been growing here ten years in deep upland soil, and have large root systems and are hardier than others.

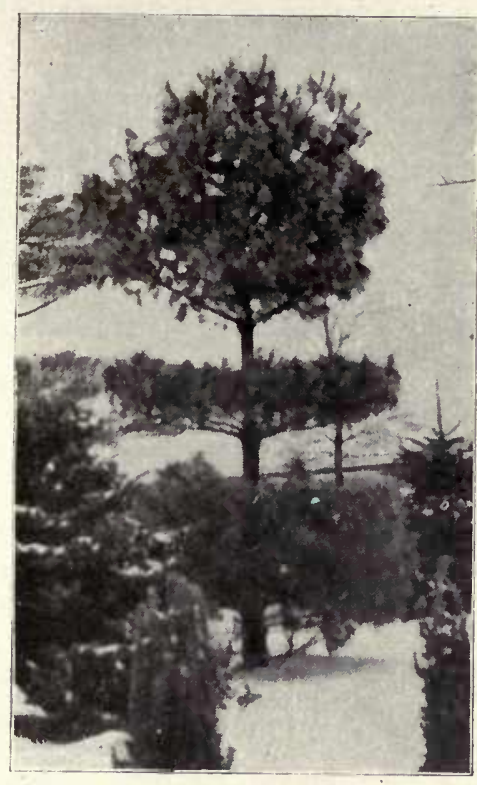

White Pine trained similar to those in the famous Italian garden of Mr. H. H. Hunnewell, at Wellesley.

WHITE SPRUCE. 6 to 20 feet. NORWAY SPRUCE. 5 to 30 feet.

ENGLISH YEW. 2 to 3 feet. Not recommended for exposed situations.

RETINOSPORA PLUMOSA. Conpact, uniform, pure green. 2 to so feet.

RETINOSPORA PLUMOSA AUREA. Broad golden pyramids. 2 to 12 feet.

RETINOSPORA SQUARROSA. Blue-green. 2 to 6 feet.

\section{SPIRES OF COLUMNAR FORM}

RED CEDAR. 4 to 37 feet. These tall spires reproduce in this climate the effects of Cypress in Italian gardens.

PYRAMIDAL ARBORVIT E. Narrow columns. 4 to I2 feet.

IRISH YEW. 2 to 3 feet. Not recommended.

IRISH JUNIPER. 2 to 3 feet. Not recominended.

SWEDISH JUNIPER. 3 feet.

3 to 7 feet. SIBERIAN ARBORVIT压. Dark rop's green foliage. 5 to I 3 feet.

SILVER FIR. 6 to i2 feet.

DOUGLAS' SPRUCE. 6 to I2 feet.

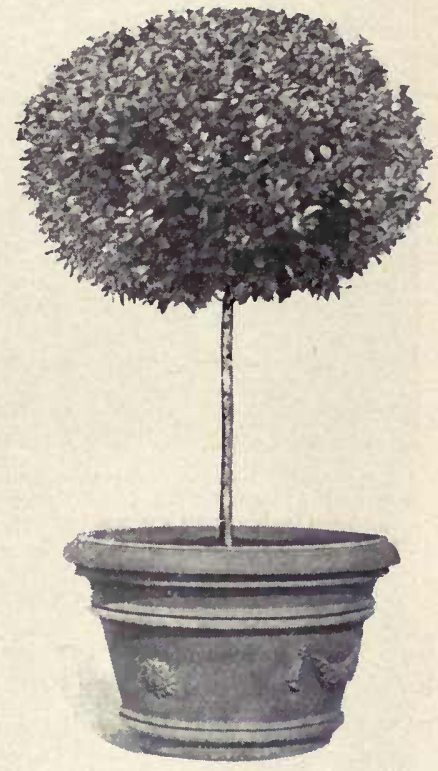

Bay tree form of Privet.

\section{EFFECT}

RED CEDAR. We offer plants from 2 to 35 feet high.

ARBORVIT瓜. Symmetrically trained trees 4 to 7

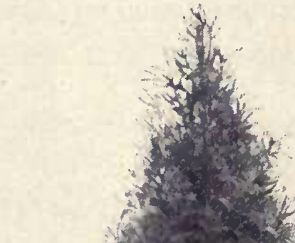




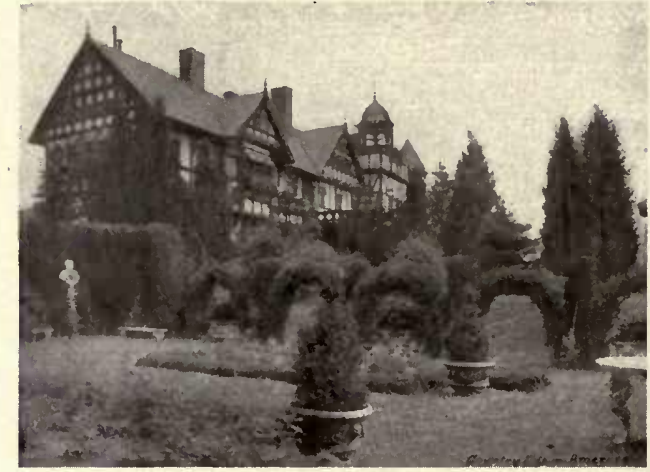

An immediate result by the use of the Hicks Evergreen Tree-mover. Italian winter garden formed by evergreen hedges and arches, backed by evergreens 25 to $30 \mathrm{ft}$. high.

SPIRES OF COLUMNAR FORM, continued

LOMBARDY POPLAR. S to I5 feet.

BOLLEANA POPLAR. 7 feet.

PYRAMIDAL TULIP. 4 to 7 feet. A healthy pyramidal tree which will supersede the Poplars for uplands.

\section{ITALIAN STONE-PINE EFFECTS}

WHITE PINE. 15 to 45 feet.

PITCH PINE. Io to 3 o feet.

\section{JAPANESE PINE AND DWARF RETINOSPORA EFFECT}

Spreading, irregular, picturesque, weird forms. (See lower illustration on page 20.)

JAPANESE PINE. $P$. densiflora. 12 feet in width.

WHITE PINE. 30 feet.

RED CEDAR, Io to 25 feet.

RED CEDAR, var. TRIPARTITA. 2 to 4 feet.

RETINOSPORA OBTUSA NANA. I to 7 feet.

\section{ARCHES, PERGOLAS, ETC.}

PRIVET ARCHES. Trained to iron forms. $8 \times 8$ feet.

CEDAR ARCHES. (See illustration on page 38.)

WEEPING MULBERRY. Trained for pergolas and tents. (See illustration on page 32.)

VINES. Six to 12 feet. For immediate results.

GARDEN POTTERY. Terra-cotta pots, vases, urns, sun-dial pedestals.

TUBS. Cypress, cedar and oak.

MATERIAL TO FILL WINDOW BOXES.

CITY GARDEN MATERIAL. We offer plants with large balls of earth that will give the best and most permanent results. For urns and tubs for city winter decoration, a single broad specimen with large root mass has a better appearance than a crowded mixture of narrow evergreens that soon lose their bright color and die.

\section{LARGE-SIZED RED CEDARS FOR HEDGES, ALLEYS, COLUMNS AND OTHER FORMAL EFFECTS}

The Red.Cedar (Juniperus Virginiana) stands preëminently at the head of our native formal trees and adapts itself to all manner of formal treatments with easy readiness. Results may be obtained which heretofore were not believed possible, and which no other of our trees can produce so effectively. They make the most beautiful of formal evergreen hedges up to 20 feet in height. When cultivated and sheared they become solid, compact walls of excellent color and texture, forming a most beautiful background for garden architecture and water features. For long evergreen alleys, vistas, and other fine and extended formal effects, they are an excellent material. It often grows individually in a tall, narrow column of solid green with a short trunk, taking the place of the classical Cypress of the Old World. These stately individual plants are imposing features in a large formal treatment. Smaller compact columns are effective at the lesser points of the design. We have in our nurseries several hundred Red Cedars I 5 to 35 feet high, besides several thousand smaller ones, prepared, root-pruned and ready for delivery. 


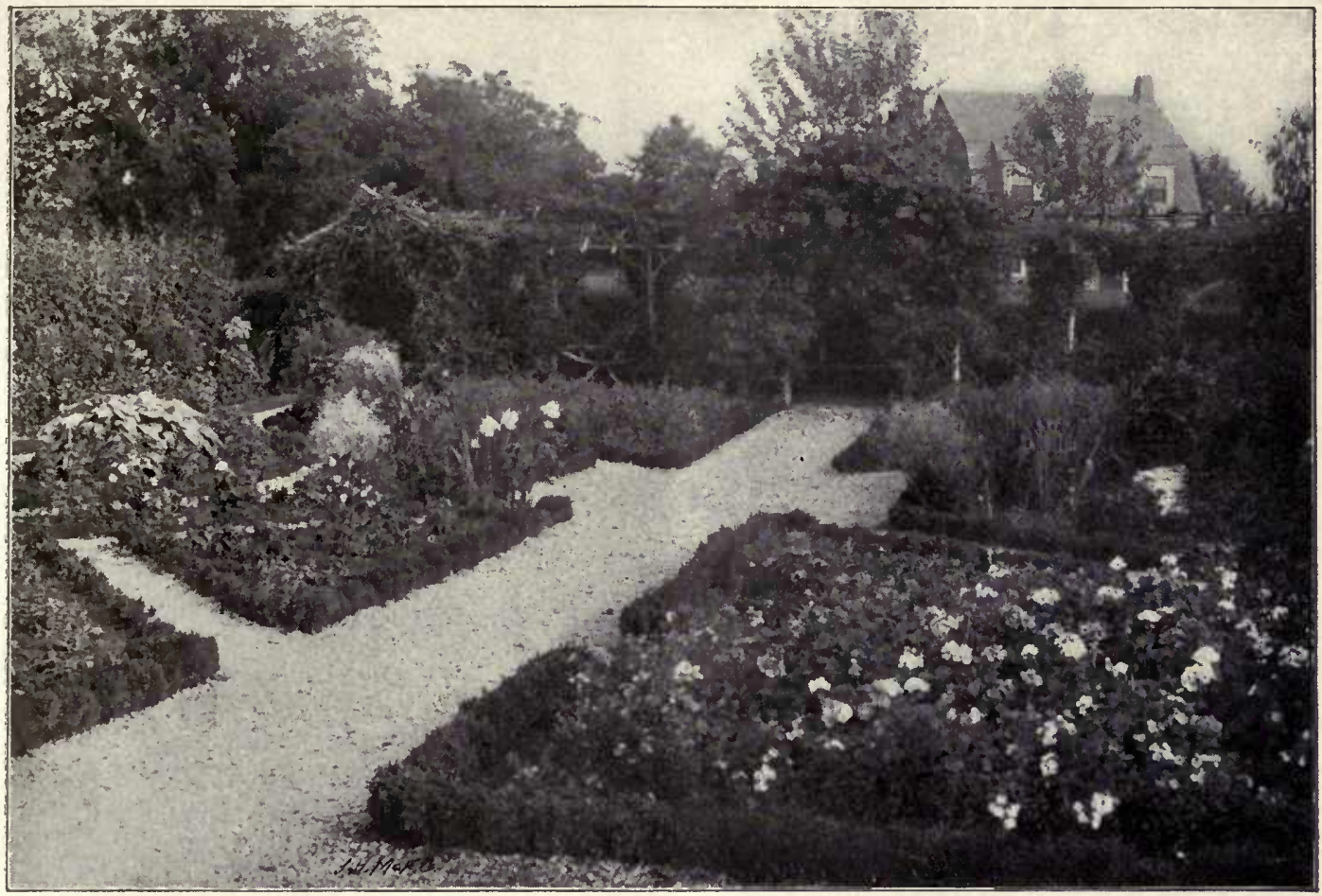

An attractive home garden of perennial and annual flowers, with a vine-covered pergola, that incidentally serves to screen an adjoining residence.

\section{Hardy Garden Flowers}

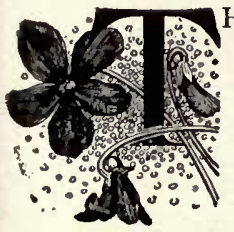

$\mathrm{HE}$ old-fashioned hardy garden is a continuous source of delight from the earliest spring, when the Crocus and Daffodils peep through the snow, through the long summer with its profusion of flowers, till late fall when the Chrysanthemum ends the flower season.

Such a garden, after it is once established, requires little care other than keeping down the weeds and the occasional division of the clumps that have become too crowded. In shrubberies the herbaceous plants give a desirable and pleasing effect, making a bright bit of color when the background of shrubs is not in bloom; thus the group is always a spot of interest and beauty.

ACHILLEA millefolium roseum. Rose-flowered Yarrow. Rose-colored form of the common yarrow. I $1 / 2$ feet. June to October.

A. Ptarmica flore pleno, "The Pearl." This plant makes a dense sod, and seems able to maintain itself in any soil. The clusters of small, double white flowers, resembling the Bridal Wreath spirea, are borne on long stems, and furnish a welcome addition to bouquets throughout the summer. 2 to 3 feet.

A. Sibirica. A neat clump of foliage of dome form, surmounted with clusters of white flowers in July. 2 feet.

ADONIS vernalis. Bright yellow flowers 2 or 3 inches across, borne in earliest spring. Foliage finely cut. March to May.

AGRostemma. See Lychnis.

ALTHAA. See Hollyhock.

ALYSSUM saxatile compactum. Tufts of showy yellow flowers. April to June. A pretty plant for edging.
AMSONIA tabernæmontana. A woody perennial, with willow-like leaves and panicles of small, bluish flowers in May and June. 2 to 3 feet.

ANEMONE Japonica. The Japan Anemone ranks with the chrysanthemum as queen of the autumn flowers. The exquisite waxy white flowers 2 to 3 inches across, with golden stamens, continue in stately profusion after the early frosts. It should be freely planted. It needs a rich soil, and should remain undisturbed for several years, the ground being slightly mulched in winter. 3 to 4 feet. September, October. See illustration, page 68.

A. Japonica, var. alba. Pure white.

A. Japonica, var. "Queen Charlotte." Large, semidouble flowers of La France pink.

A. Pennsylvanica. This has large cream-white flowers all summer. An excellent plant. I2 to 15 inches.

ANTHEMIS tinctoria. Chamomile; Golden Marguerite. Yellow daisy flowers and finely cut foliage. $I \frac{1}{2}$ to 2 feet. July. 


\section{ANTHERICUM liliastrum. See Paradisea.}

AQUILEGIA. Columbine. The flower of the Columbine differs from all others, the conspicuous feature being the long, tapering spurs arching gracefully upward, holding a drop of honey at the apex. It is the first flower ready for the hummingbird upon his arrival from the tropics. 2 to 3 feet. May and June.

A. cœrulea. Rocky Mountain Columbine. An exquisite blue and white flower.

A. chrysantha. A long-spurred yellow variety. 3 feet. July and August.

A. alba. A white-flowered form of the above.

A. glandulosa. Shaded blue and white.

A. hybrids. A fine collection of double and single in many shades of blue, purple, yellow, white, red and pink.

ARMERIA plantaginea. Thrift, or Sea Pink. The plant is a low evergreen tuft of moss-like foliage. producing clusters of pink flowers on stems about 6 inches high. All summer.

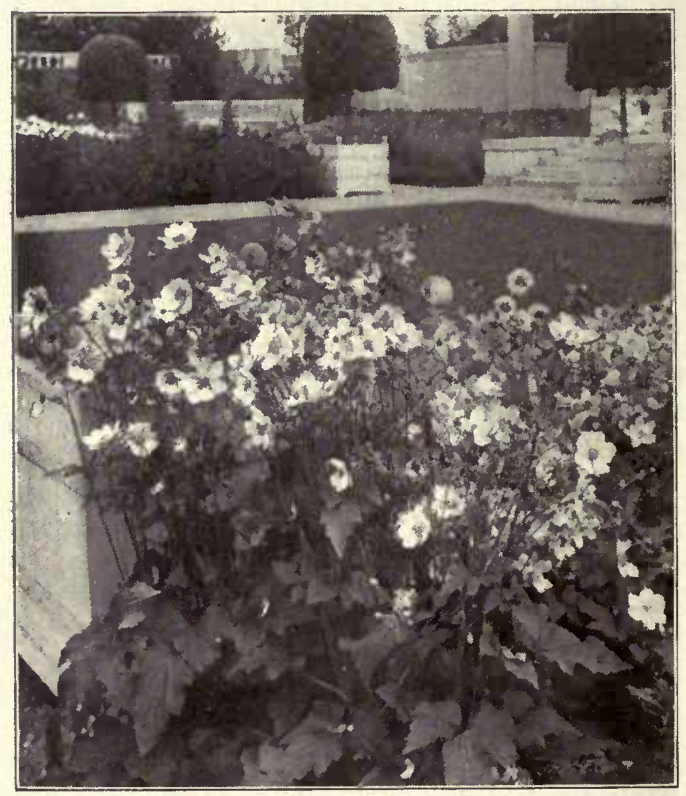

Anemone Japonica. (See page 67.)

ARTEMISIA Abrotanum. Southernwood; Old Man. 'The silvery gray, fern-like foliage has a strong aromatic odor. It thrives in the drier portions of the rock garden and combines well with cut-flowers.

ASCLEPIAS tuberosa. Butterfly Weed. One of the showiest perennials. Brilliant orange-colored flowers in compact umbels. Occasionally on dry hills. 2 feet. July to September.

ASTER. Under the name of Michælmas Daisy the various species of hardy Asters hold an important place in the English hardy gardens. Their brilliant star-like flowers are borne in such profusion that they make great masses of color during late summer. September and October.

A. grandiflorus. The most showy varietv, with flowers of deep violet-blue, 2 inches in diameter. I $1 / 2$ feet. October and November.
Aster Novæ-Angliæ. One of the best of our native Asters, with large purple or rose-colored blossoms in September and October. Excellent for bold groups among shrubs, and to produce masses of color at a tinie when there are but few flowers. 3 to 4 feet.

A. Tataricus. Large brilliant blue flowers, lasting even later than the above and valuable for the same purposes. A tall and stately plant. 6 to $7 \mathrm{ft}$.

ASTILBE Japonica. Spira Japonica. The cliaracteristics of this little plant are delicacy and refinement. The cut leaves are dark green, and the flower-spikes of feathery white. I foot. May.

BABY'S BREATH. See Gypsophila.

BAPTISIA australis. Blue Wild Indigo. The single upright stem branches like a little tree and bears spikes of indigo pea-shaped flowers in July. 2 to 3 feet.

BELEMCANDA Chinensis. Blackberry Lily. This is an iris-like plant with seed-clusters resembling the blackberry. The flowers are bright orange, borne on stems $2 \mathrm{~L} / 2$ feet long during July and August.

BELLFLOWER. See Campanula and Platycodon.

BELLIS perennis. English Daisy. A little gem among plants. In early April it welcomes the spring with dainty pink and white flowers, which continue during the summer and appear freely again in the cool days of autumn. It should be placed at the front of the border with Forgetme-nots.

BEE BALM. See Monarda.

BETONICA. See Stachys.

BLACKBERRY LILY. See Belemcanda.

BLANKET FLOWER. See Gaillardia.

BLEEDING HEART. See Dicentra.

BLOODR00T. See Sanguinaria.

BOCCONIA cordata. Plume Poppy; Tree Celandine. A bold, picturesque plant, having large, blue-green leaves and open panicles of creamwhite flowers, larger than the Hydrangea. Useful in shrubberies or wild planting, but its spreading roots render it unsuitable for the small garden. 5 to 8 feet. Mlidsummer.

BOLTONIA asteroides. A plant closely resembling the wild Asters and producing sheets of starry white flowers. Suitable for planting in masses in the shrubbery or near woodlands. 4 to 6 feet. August and September. (See illustration, opposite page.)

BUTTERCUP. See Ranunculus.

CACTUS Opuntia. Prickly Pear. A native of some of the most gravelly soils on Long Island. It has delicate yellow flowers 3 inches in diameter. We have used it to plant on terraces, in wild gardens, which were nearly vertical, the soil being temporarily held by wire netting. It grows in the cleft of the rocks high up in the Palisades.

CAMPANULA. Canterbury Bell; Bellflower. These are old-time garden favorites. Tall, stately spikes.

C. persicifolia. Blue flowers in June and July. $1 \mathrm{I} / 2$ to 2 feet.

C. persicifolia Moerheimei. Spikes of pure white, camellia-like flowers. I $1 / 2$ to 2 feet. 
CASSIA Marylandica. Wild Senna, A showy plant, with panicles of curious yellow and black-spotted flowers, from July to September. Useful for planting on dry, gravelly banks. 3 feet.

CENTAUREA macrocephala. A vigorous plant, with broad leaves surmounted with globular yellow, thistle-like flowers. 2 feet. June and July.

CERASTIUM tomentosum. Mouseeared Chickweed. A creeping plant, with silvery gray leaves and numerous white bells in May and June. Suitable for edging garden beds, for the rockery, or to cover steep banks. 6 inches.

\section{CHAMOMILE. See Anthemis.}

CHRYSANTHEMUM. The hardy Chrysanthemum belongs to the pompon class. They are oldfashioned garden favorites, giving abundant flowers when the other flowers are gone. 2 to 3 feet. October.

We offer a list of the best selected varieties of white, pink, red and yellow.

Prince of Wales. Best white.

Anna Mary. Cream-white.

Eagle d'Or. Yellow.

Princess Louise. Bronze.

Julia Lagravere. Dark bronze.

Rhoda. Delicate pink.

St. Illoria. Silver-pink.

Little Pet. Rose.

C. inodorum. A tuft of fern-like foliage a few inches high, with small, pure white, double flowers in July.

c. uliginosum. Giant Daisy. A vigorous plant, covered with white daisy-like flowers, 3 inches in diameter. July to September.

CLEMATIS Davidiana. A shrub-like plant about 4 feet high, bearing fragrant blue flowers resembling Hyacinths, in clusters. August and September.

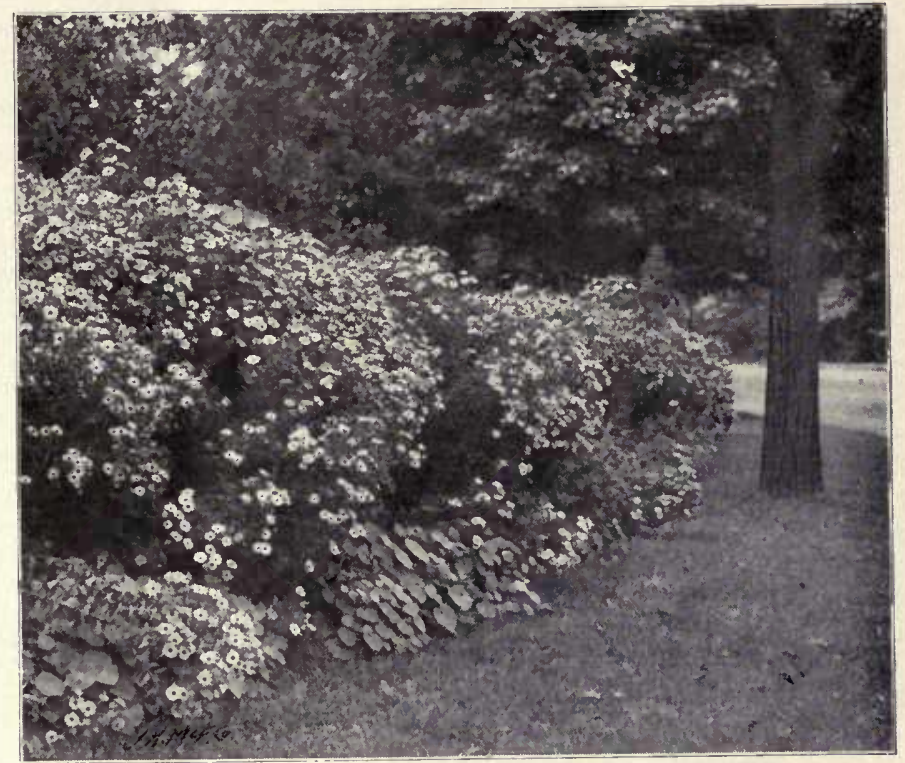

Boltonia asteroides. (See preceding page.)

Clematis recta. A similar plant, with exquisite white flowers. Very fragrant. 2 to 3 feet. June to August.

CONE-FLOWER. See Rudbeckia.

CONVALLARIA. Lily-of-the-Valley. Spikes of fragrant white bells among luxuriant green leaves. It has a partiality for shaded situations, which explains its frequency on the north side of a house, as well as the persistency with which it covers the ground under old trees around oldfashioned gardens. 6 inches. May.

COREOPSIS. Among the numerous yellow Daisies this remains longest in bloom, affording a brilliant mass of color in the garden, and longstemmed graceful flowers for cutting, from June till September. 2 to 3 feet.

c. lanceolata. I to 2 feet. The best sort for cutflowers.

C. verticillata. I to 3 feet.

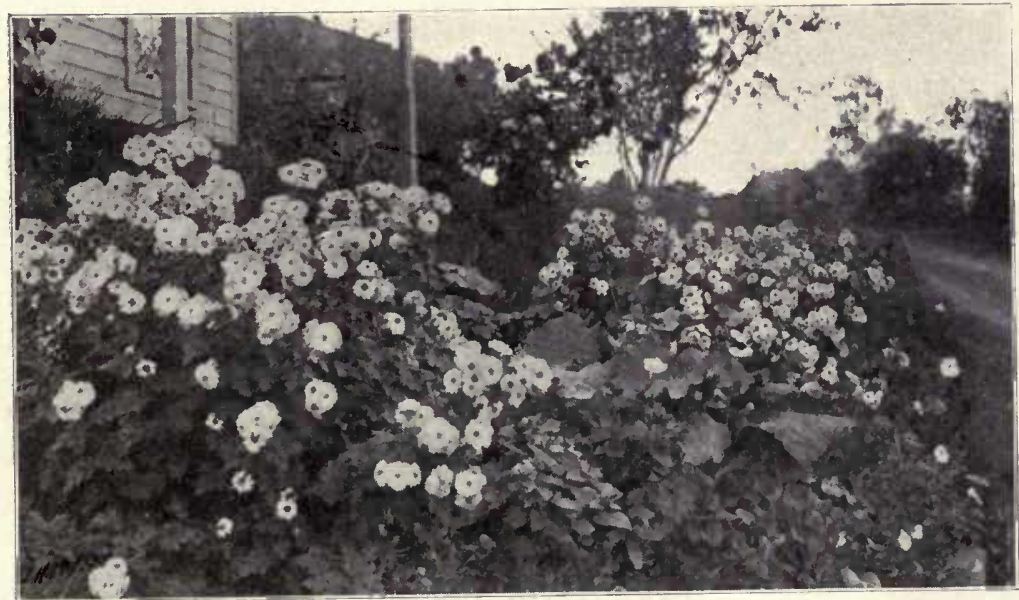

Mass planting of hardy Chrysanthemums.
COWSLIP. See Primula. CYPRIPEDIUM acaule. Ladies' Slipper ; Moccasin Flower. A beautiful hardy native Or. chid. Pouch - shaped flowers 2 inches long, of rose color, veined with deeper rose, are borne on slender stems above two leaves. Plant in the fern bed or dry oak woods. 6 to 8 inches. May. Of easy culture, this should be more often planted.

DAFFODILS. See Narcissus.

DAISY. See Bellis.

DAY LILY. See Funkia and Hemerocallis. 
DAPHNE Cneorum. A tiny alpine shrub with trailing woody branches and evergreen leaves. The bright pink, spicily fragrant flowers appear in early May and June, and occasionally dirring the summer. The plant has somewhat the habit and all the attractiveness of the Trailing Arbutus.

DELPHINIUM. Larkspur. The stately Delphiniums lend a classical dignity to the garden, and add the clear blue so rarely found. They have showy racemes of long-spurred blossoms in white and several shades of blue. 2 to 7 feet. June to September.

D. Cashmerianum. Pale blue. July and August.

D. grandiflorum, var. Chinense. Blooms continuously from June to September. Flowers of the lighter blues and white. The foliage is finely cut. I 8 inches.

D. formosum. Indigo-blue. The old-fashioned sort. Has a continuous succession of flowerspikes. 4 feet.

Kelway's Hybrids. A very fine range of colors, in tall, vigorous spikes. 5 to 7 feet.

DESMOdIUM. See Lespedeza.
Dianthus plumarius. Double and single hardy garden Pinks in a variety of colors.

DICENTRA spectabilis. Bieeding Heart. An oldfashioned plant sending up branches of deeply cut foliage in early spring, followed by drooping racemes of pink heart-shaped flowers. Strong and luxuriant. 2 to 3 feet.

D. eximia. Dainty fern-like foliage and bright rosecolored flowers that continue all summer. I foot. This is one of the most valuable of the hardy herbaceous plants, because of persistent blooming qualities. Plant in the garden border or in the wild garden. (See illustration page $7 \mathbf{r}$.)

DIGITALIS. Foxglove. A dignified old-time plant with tall spikes of bells, ranging in color from white to rose and purple. June and July. 2 to 5 feet.

DORONICUM plantagineum excelsum. This attractive plant gives a bright yellow touch to the garden early in April. The leaves are broad, and the flowers, borne on tall, graceful stems, are 4 inches in diameter.

EULALIA. See Miscanthus.

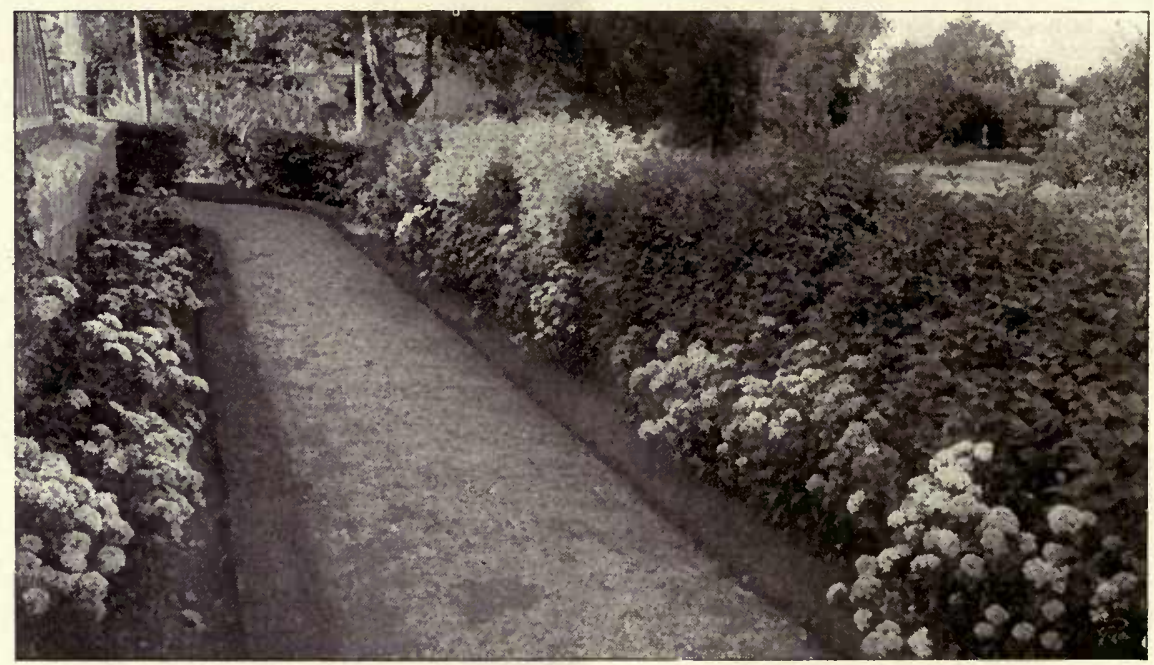

Border of Dianthus barbatus. Sweet William.

DIANTHUS. Pink. The hardy Pink is the prototype of the carnation. The gray-green, grasslike foliage is attractive throughout the year. They prefer a rather dry position, such as the edge of a raised bed. I foot. May and June.

June Pink. White. The old-fashioned clove. scented white Pink. Should be planted extensively. An excellent border plant.

D. barbatus. Sweet William. A showy old-fashioned perennial, with wide, flat heads of flowers in brilliant combinations of red and white. An excellent bedding plant for color effect. Fragrant. I foot. June and July.

D. Chinensis. China Pink. A biennial plant blooming brilliantly from May to October. The petals are brightly marked and splashed in many shades of red and pink and white. Fine for bedding for color effect. 6 inches.

D. delicata. Bright pink.

D. Homer. Rich rosy red, with dark center.
EUPATORIUM cœlestinum. The hardy Ageratum. A sheet of deep blue in August and September. Useful where an even mass of color is needed in formal gardening.

EUPHORBIA corollata. Flowering Spurge. The small milk-white flowers on wide branching panicles are useful for making up with other flowers in the same manner as Baby's Breath. I 8 inches. June to August.

FESTUCA glauca. Blue Fescue Grass. This makes a bright bluish green clump in the rock garden, or may be used as a border.

FEVERFEW. Double cream white flowers; button shape. All summer. I2 to 15 inches.

FLEUR-DE-LIS. See Iris.

FORGET-ME-NOT. See Myosotis.

FOXGLOVE. See Digitalis.

FUNKIA. Day Lily, or Plantain Lily. 
FUNKIA ovata. Blue Day Lily. Broad leaves and graceful stems, bearing slender blue Lilies. I I $1 / 2 \mathrm{ft}$. August.

F. subcordata. White Day Lily. The white Day Lily of our grandmother's gardens. A clump of large rich leaves surmounted in midsummer with spikes of pure white Lilies, with golden stamens and the fragrance of the Madonna Lily. 2 feet.

F. lancifolia. Clusters of lance-shaped foliage, nuaking a symmetrical plant 2 feet or more in diameter, and long, showy spikes of lavender flowers.

F. lancifolia, var. variegata Leaves handsomely variegated with green and gold. A low border plant.

GAILLARDIA aristata. Blanket Flower. One of the most showy and effective hardy plants that will thrive in any location. The newer varieties of Gaillardia give a wide range of red, orange and yellow. They afford a bowl of daisy-shaped flowers any day during summer or autumn. 2 feet.

GERANIUM sanguineum. A native hardy Geranium, having cut leaves and rosepurple flowers. $\mathrm{r} 1 / 2$ feet. June to August.

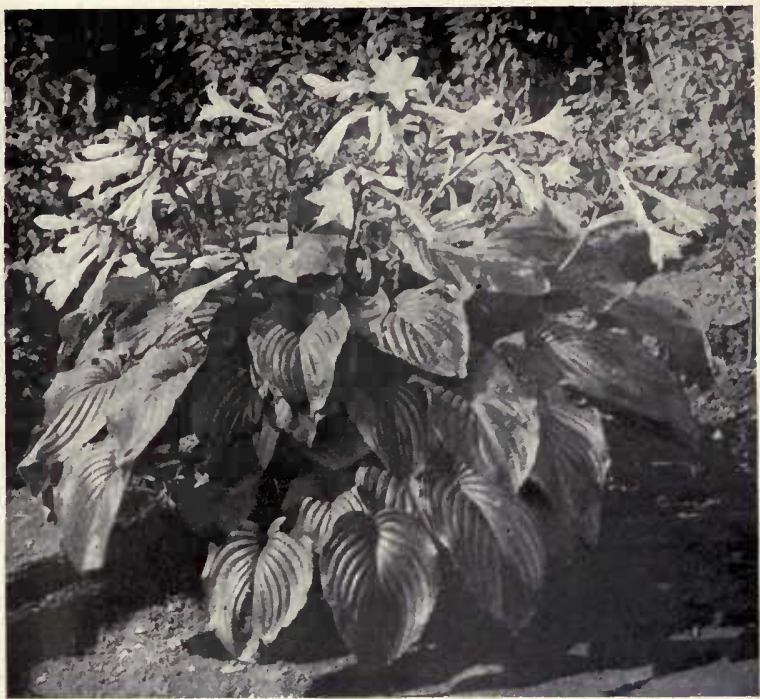

Funkia subcordata.

Helianthus Maximiliana. Single bright yellow flowers. Most effective planted in the shrubbery in connection with Aster Tataricus, as they, with the hardy Chrysanthemums, are the last to yield to frost. 6 to 8 feet. September and October.

H. mollis. Downy white foliage and single lemoncolored flowers. 4 feet. August and September.

H. orgyalis. Long, narrow, drooping foliage, surmounted by numerous golden flowers. Plant for foliage effect. 7 to 8 feet. September and October.

HELIOPSIS lævis, var. Pitcheriana. A plant resembling Helianthus, but dwarfer in habit, and blooming profusely in midsummer. Deep golden yellow. 3 feet.

\section{HEMEROCALLIS. Day Lily.}

H. flava. These Lilies grow freely in any situation. The flowers are lemon-yellow, appearing in June and July.

H. fulva. Tawny Day Lily. The old-fashioned tawny Lily often found by the roadside, escaped from old gardens. 3 feet. Effective in shrubberies. July.

H. fulva fl. pl., var. Kwanso. The double form, blooming longer than the preceding. 4 feet.

HIBISCUS. Marsh Mallow; Rose Mallow. While the natural habitat of Marsh Mallows is the salt marsh, they are equally at home in the border. The flowers are larger than those of the Hollyhock, and are pink and white in color. 4 feet. August.

H. Moscheutos. Pink.

H. Moscheutos, Crimson Eye. White, with crimson eye.

HOLLYHOCK. Allhea rosea. These stately plants are indispensable in the garden or border. They are especially pleasing as they throw up their tall spikes of bright color against a vine-covered pergola or wall. We offer a good variety of sorts, including the single ones that have been so difficult to obtain in quantity. 5 to 7 feet. July and August. (See illustration, page 72.) 
IRIS. Fleur-de-Lis.

I. Germanica. German Iris. One of the most valuable and attractive plants, of easy culture, adapted to gardens, shrubberies or margins of water. The foliage is always good, and the flowers as delicate and beautiful as an orchid. Our collection comprises sorts ranging in color from white to deep blue, with variations of yellow, brown and maroon. They should be planted largely. A charming effect is produced by planting Iris and Columbine together. 21/2 feet. May and June.

I. lævigata (Kæmpferi). Japanese Iris. The Japanese gardeners have exemplified their skill in the wide range of colors and blendings, and in the huge size to which they have developed this flower. In late June and July great flowers 6 inches or more across, in blues, purples, pinks, reds and whites, with innumerable variations, make a sight never to be forgotten. Plant in great masses in the shrubbery border, the garden, the aquatic garden, and by the edges of ponds, where they reach their highest development. 3 feet.

I. cristata. Early Iris. This grows 4 inches high and in May is a sheet of light blue flowers, spotted with yellow. Equally valuable in the garden border or water garden. We offer several thousand.

I. Sibirica. Siberian Iris. A variety with narrow leaves and intense deep blue blossoms borne on slender red stems. $21 / 2$ feet. June.

I. Hispanica. Spanish Iris. Yellow flowers, otherwise resembles the German Iris.

I. pumila hybrida. A cross between the German and diwarf early Irises. It blooms earlier than the German, and is a very attractive variety. I foot.

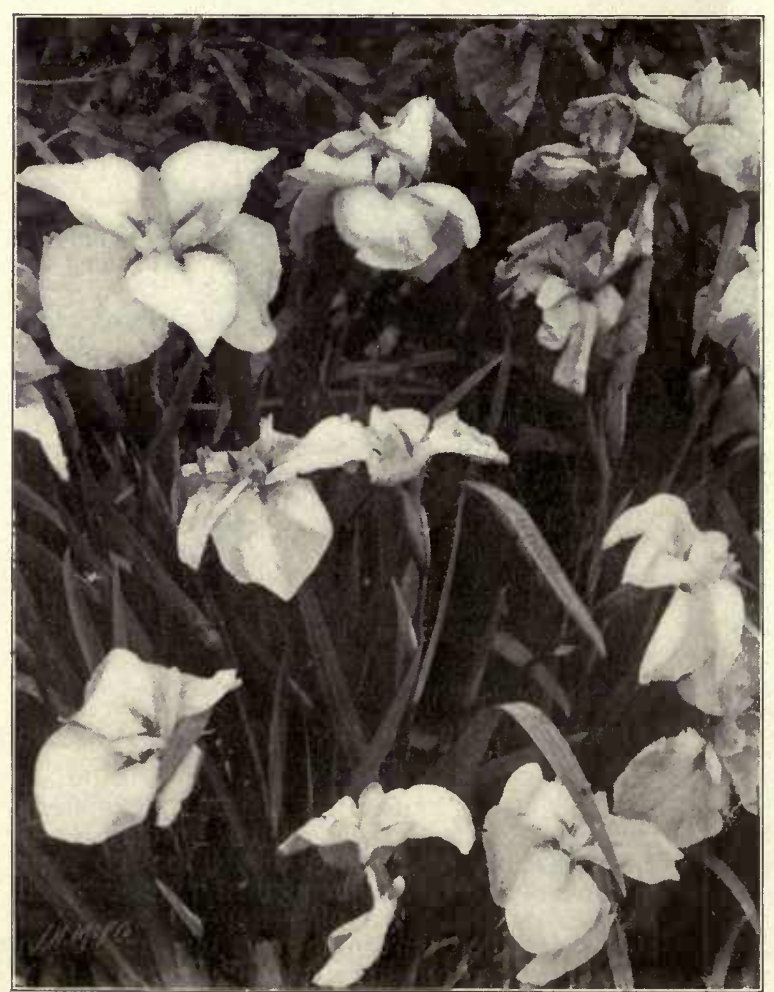

May.

I. Cyanea. Rich royal purple, with blackish shadings.

I. Eburna. Pure white, with creamy shadings.

I. florida. A beautiful lemon-yellow, shaded darker.

I. formosa. Upper petals deep violet-blue, lower petals light violet.

KNIPHOFIA Pfitzerii. Flame-Flower; Tritoma ; Red-Hot-Poker Plant. Broad tufts of grass-like foliage, from which ascend spikes of brilliant flowers-deep scarlet in the bud, opening yellow-making a shaded flame of color. Mulch in winter. 4 feet. August to October.

LESPEDEZA Sieboldi, syn., Desmodium penduliflorum. This member of the pea family grows so vigorously that it is equally valuable in the shrubbery or in the garden. It is able to thrive in any situation. The flowers are rosy purple and borne in great profusion in early September. 4 to 5 feet.

LARKSPUR. See Delphinium.

LILY-OF-THE-VALLEY. See Convallaria.

LILIUM candidum. The Annunciation Lily. Tall spikes of fragrant white Lilies. 5 feet. June, July.

L. tigrinum splendens. Tiger Lily. One of the showiest and most easily grown Lilies, occasionally escaping to roadsides. The flowers are orange-red, spotted with black. Garden or shrubbery. 5 feet. August.

LOOSESTRIFE. See Lysimachia. 
LYCHNIS Chalcedonica. Maltese Cross, or Scarlet Lightning. The most brilliant scarlet in the garden, for the clusters of small flowers seem to glow like heated metal. 2 to 3 feet. July to September.

I. Haageana. Resenbles the last, with larger flowers. 6 inches. May and June.

L. coronaria. Mullein Pink; Rose Campion. White woolly foliage and flowers of a rich crimson or white color and velvety texture. It blooms all summer. I to 2 feet.

I. Flos-cuculi. Ragged Robin. Sends up spikes of rose-crimson double flowers from a tuft of evergreen foliage. Blooms profusely for a long time. $\mathrm{I} / 2 \mathrm{ft}$. June.

LYSIMACHIA clethroides. Loosestrife. A plant 2 feet high, with gracefully bending spikes of white flowers. Brilliant foliage in the late autumn. July to September.

MALLOW. See Hibiscus.

MENTHA. Mint. A hardy plant used for flavoring.

MICHÆLMAS DAISY. See Aster.

MILKWEED. See Asclepias.

MISCANTHUS Sinensis. Eulalia Japonica. The Eulalia grass grows 7 to 8 feet high, and should be used in the shrubbery and water garden for immediate effect. In September the downy plumes appear and are used for winter decoration, as is the Pampas grass, which they closely resemble. The different varieties are M. Sinensis, var. gracillima, which has narrow leaves and is perhaps the most ornamental; var. variegata, with foliage striped green and white; var. zebrina, which has cross bands of yellow.

MOCCASIN FLOWER. See Cypripedium.

MONARDA didyma. Oswego Tea; Bee Balm. A showy herb, having aromatic foliage and flowers of an intense red. A brilliant mass of color in garden, shrubbery or water garden, rivaling the Salvia. 2 feet. June to September.

MYOSOTIS. Forget-me-not. No garden is complete without a border of these dainty blue blossoms. 6 inches. May and June.

NARCISSUS Pseudo-Narcissus. Common Double Daffodil. The hardy old-fashioned kind. Great golden balls. April.

N. incomparabilis. Single yellow. Increases rapidly and is particularly useful planted extensively in the grass. April.

N. pceticus. Poets' Narcissus. A pure white single Narcissus, the yellow central cup being edged with a red frill. I foot. May.

OLD MAN. See Artemisia.

P EONIA Sinensis. The Peony will grow and persist in any soil, but reaches its highest development in deep fertile loam. Fven when out of flower the foliage of the Peony is an ornament to the garden. We have many fine named varieties in a wide range of color, from white to deepest red. 2 to $2 \frac{1}{2}$ feet. June.

P. officinalis. This old-fashioned sort blooms early in May before the other Peonies. The red variety is of the deepest glowing color, while the pink and white are equally attractive.
Pæonia Moutan. Tree Peony. A slow-growing woody shrub of an irregular picturesque shape, bearing very beautiful silky blossoms. Decidedly Japanese in effect. 4 to 6 feet. May.

PAPAVER nudicaule. Iceland Poppy. From the clusters of low, fern-like foliage spring many stems bearing white, yellow and orange-scarlet Poppies. I foot.

P. orientale. Oriental Poppy. An entirely hardy Poppy. A clump will increase in vigor for years and present each June a most gorgeous sight with its great flowers in brilliant reds. $2 \frac{1}{2}$ feet.

PARADISEA Liliastrum. St. Bruno's Lily. A slender and delicate plant with a spray of little white lilies in May. I $1 / 2$ feet.

PENTSTEMON barbatus, var. Torreyi. A plant with very slender, graceful spikes of brilliant scarlet trumpets. 3 to 4 feet. June to August.

PERIWINKLE. Myrtle. See Vinca.

PHLOX decussata, or paniculata. Most of the named garden Phlox are of this species. In brilliancy of color the hardy Phloxes have been greatly improved, and we aim to keep only the best in each shade. Planted en masse they make a beautiful show and may be kept in flower until frost by pinching back some of the plants.

La Cygne. Pure white. Very fine.

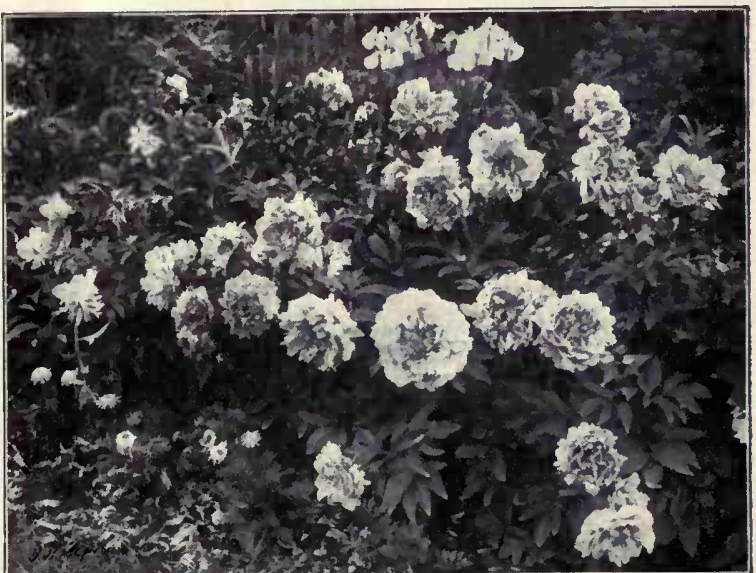

Peonies growing in the Havemeyer garden at Hempstead, L. I.
Bridesmaid. Pure white, with crinsson center.

Coquelicot. Pure scarlet; carmine eye. The finest red yet known.

Cross of Honor. Pure white, with a band of roselilac across each petal, forming a Maltese cross.

Eclaireur. Purplish crimson, with white halo.

General Chanzy. An exquisite pink.

Fiancee. Large, pure white.

William Ramsay. Fine, deep rose-purple.

P. reptans. A low plant, forming a dense sheet of reddish purple flowers in May. 3 to 8 inches.

P. subulata. Moss Pink. This plant is an excellent substitute for grass on steep and dry terrace banks, as it revels in sunshine and sandy soil and quickly covers the ground to the exclusion of other vegetation. In May the mossy evergreen foliage is completely hidden by the flowers. We offer it by the thousand. It is cheaper than grass. 


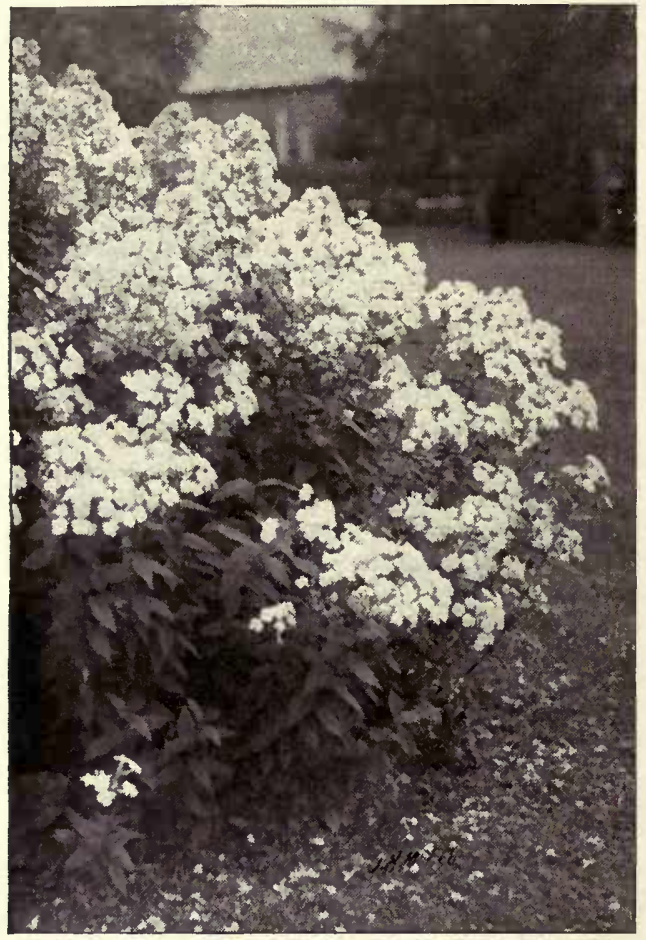

Phlox decussata. (See page 73.)

Phlox subulata, var. rosea. $\square$ A bright rose-pink. P. subulata, var, alba. Pure white.

PINKS. See Dianthus.

PLATYCODON grandifiorum. Campanula grandiflora; Chinese Bellflower. A valuable perennial, with blue or white bell-shaped flowers, resembling the Campanula, but having broader bells. I to 2 feet. June to October.

PLUME POPPY. See Bocconia.

POLYGONUM Sieboldi. $P$. cuspidatum; Knotweed. A large, bushy perennial, with stems gracefully curving outward, enveloped in clouds of fine whitish flowers. 4 to 7 feet. July.

P. sachalinense. Similar to, but larger than the above. They both spread rapidly, and should be planted where this habit is not a detriment. Effective for bold masses in wild places. 8 to I2 feet. July.

POLYGONATUM. Solomon's Seal. A desirable plant for shady places. Graceful sprays, bearing pendent green-white bells, after the manner of Lily-of-the-valley. 2 to 3 feet. June.

POPPY. See Papaver.

PRICKLY PEAR. See Cactus.

PRIMULA. Primrose. Small compact plants, with bright blossoms, that should be found in every garden.

P. veris. English Cowslip. One of the earliest spring flowers. The well-known hardy Primrose in a variety of colors-rich reds and yellows. 5 inches. April and May.

P. vulgaris. English Primrose. Canary-yellow and fragrant. The old sort. 5 inches.

PYRETHRUM roseum. An excellent flower for cutting. Flowers resemble the China Aster, and are about 3 inches across. White, pink and red. I $1 / 2$ feet. May and June.

P. uliginosum. See Chrysanthemum uliginosum.

RANUNCULUS acris flore pleno. Double Buttercup. A neat clump of foliage, with shining yellow buttercups. I I $1 / 2$ feet. May to August.

R. repens, var. flore pleno. A creeping plant, suitable for wild gardens, cover for banks and margins of water. Spreads rapidly. Double bright yellow. 8 inches. May and June.

RAGGED ROBIN. See Lychnis.

RED-HOT POKER PLANT. See Kniphofia.

RUDBECKIA laciniata, “Golden Glow." Coneflower. This popular plant is the most conspicuous object in the border in August. The blooning season may be prolonged by cutting back some plants before or after the first flowering. The flowers are double, rich golden yellow and shaped like Dahlias. Borne in great profusion. 6 to 8 feet. July to September.

R. maxima. Broad smooth green foliage, with very large bright yellow flowers with a central cone 2 inches long. 5 to 6 feet.

R. triloba. A neat, sprightly plant. The best of its sort. Completely covered with golden vellow flowers with black centers. 3 to 4 feet. August and September.

SALVIA azurea, var. grandiflora. In early autumn this bears loose panicles of pure blue flowers. 2 to 3 feet. August and September. A rare and beautiful addition to the flower border.

SANGUINARIA Canadensis. Blood-root. A harbinger of spring which appears too delicate for the cold winds of March. Pure white flowers 3 inches in diameter. Will grow in the open, but prefers the company of ferns.

SEA PINK. See Armeria.

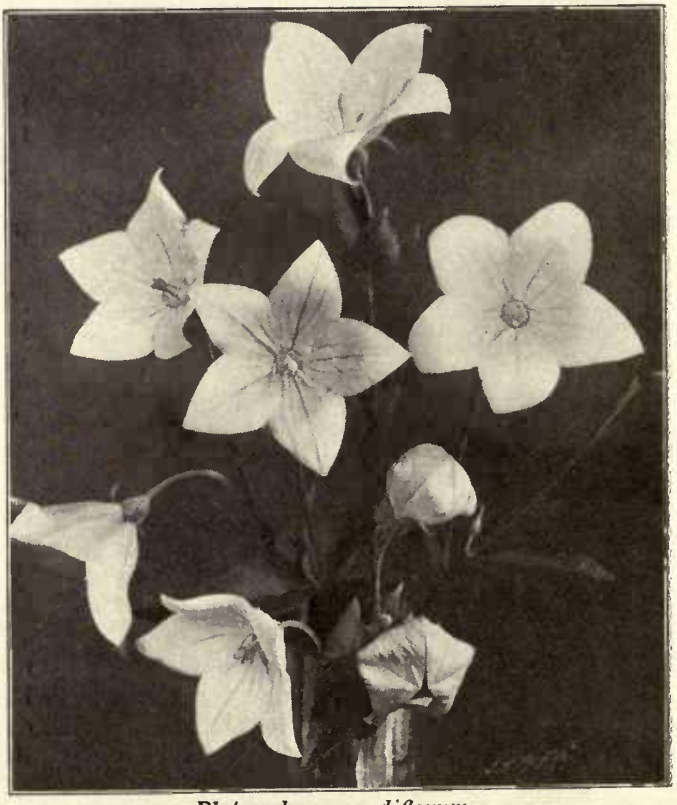

Platycodon grandiflorum. 
SEDUM acre. Stonecrop. A creeping plant with bright golden star-shaped flowers in May. Thrives in the driest portions of the alpine garden, and may be used at the top of stone walls as a cover plant.

S. album. A similar plant with white flowers.

S. spectabile. Japanese Live-forever. Has broad flat heads of rose-colored flowers. Excellent for edging beds.

SILPHIUM perfoliatum. Cup Plant. A stately plant with large leaves, squared stems and lemonyellow blossoms 3 to 4 inches across. 6 feet. Midsummer.

SOUTHERNWOOD. See Artemisia.

SPIREA Japonica. See Astilbe.

SPIDERWORT. See Tradescantia.

STOKESIA cyanea. Stoke's Aster. A very beautiful blue flower 4 inches across. It resembles the Cornflower of Germany. Blooms continuously from July till October. I $1 / 2$ to 2 feet.

STACHYS Betonica rosea. Betony. Spikes of rosy red flowers about so inches high. June and July.

STONECROP. See Sedum.

SUNFLOWER. See Helianthus.

SWEET WILLIAM. See Dianthus.

THERMOPSIS Caroliniana. Vigorous upright plant bearing spikes of yellow pea-shaped blossonis. Will thrive in poor soil. 3 feet. June and July.

THYMUS Serpyllum, var. citriodorus. Lemon Thyme. A low evergreen creeper. Its aromatic foliage is used for flavoring. Excellent for borders or as cover in dry places.
Thymus Serpyllum, var. aureus. A golden variegated form.

THRIFT. See Armeria.

TRADESCANTIA. Spiderwort. A plant of the old-fashioned gardens, sometimes persisting after the house has gone to ruins. Flowers bright violet-blue. 2 feet. June to September.

T. alba. A white form of the above.

TRITOMA. See Kniphofia.

TROLLIUS Europæus. A member of the Buttercup fanily, with bright yellow globular flowers 2 inches. through. 2 feet. May to August.

VALERIANA. Valerian. An old-time garden favorite. The pinkish white flowers are borne in wide, open panicles. Spicy. 2 feet. May and June.

VERONICA spuria. $V$. amethystina; Speedwell. Amethyst-blue flowers in spikes. $2 \mathrm{ft}$. May and June.

V. spicata. Flower-spikes bright blue. I $1 / 2$ feet.

VINCA. Myrtle, or Periwinkle. A beautiful evergreen cover plant. Leaves shining, rich green, with flowers of clear blue in May. For uses, see under Broad-leaved Evergreens. 6 inches. Low rates per thousand. See illustration on page 56.

YUCCA. Spanish Bayonet; Adam's Needle. A fine evergreen plant, having long, sharp-pointed leaves or needles, somewhat resembling the Century Plant. The beautiful creamy bells are borne in stately spikes. To get the full effect of their beauty they should be seen against an evergreen background. Excellent for dry banks. Plant in masses. 4 to 7 feet. June and July. See illustration on page $5^{8}$.

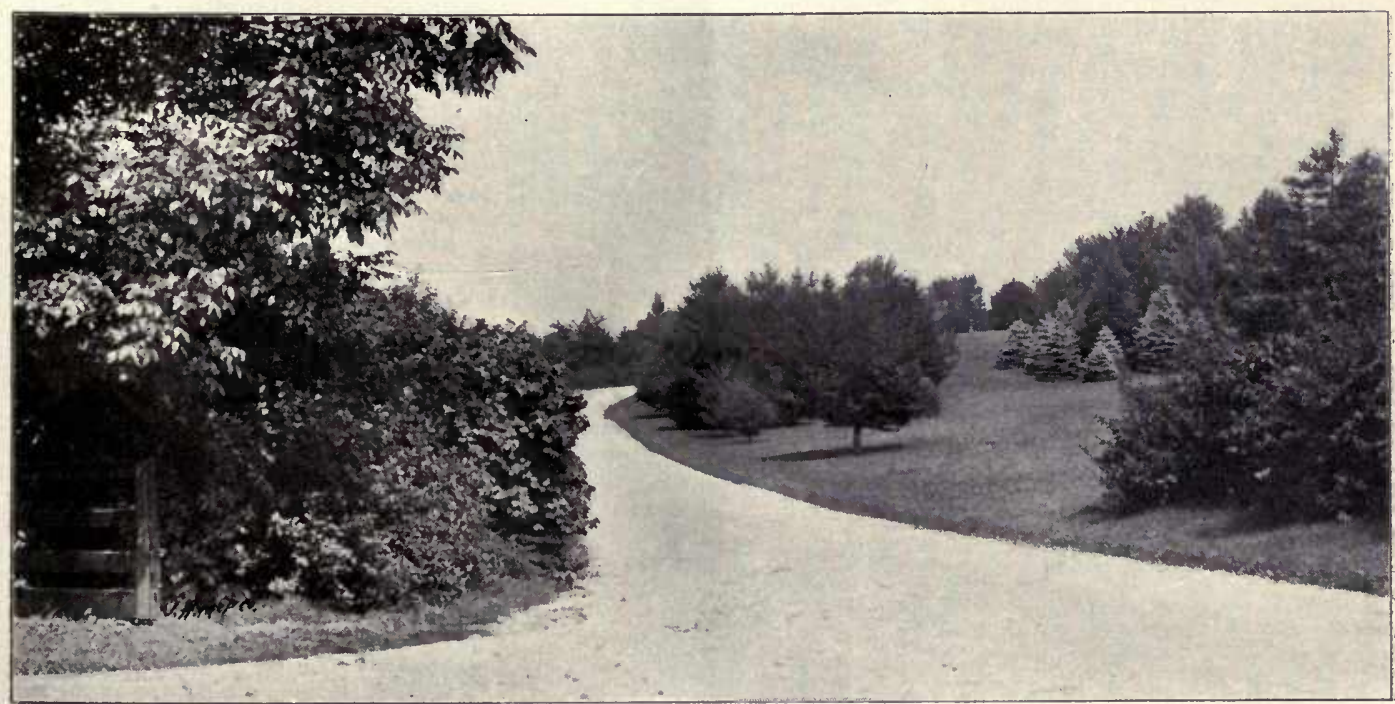

On the left a steep roadside bank made safe by a dense planting of shrubbery; on the right, yroups of Pin Oak and Colorado Blue Spruee. Estate of Mr. Hamilton Cary.

\section{Hardy Flower Calendar}

For the convenience of the garden-maker in planting for a continuation of flowers, the hardy perennials are arranged alphabetically, on the following pages, by months to show the period of bloom. In some cases several varieties of a species should be planted to furnish the succession. 


\section{HARDY FLOWER CALENDAR}

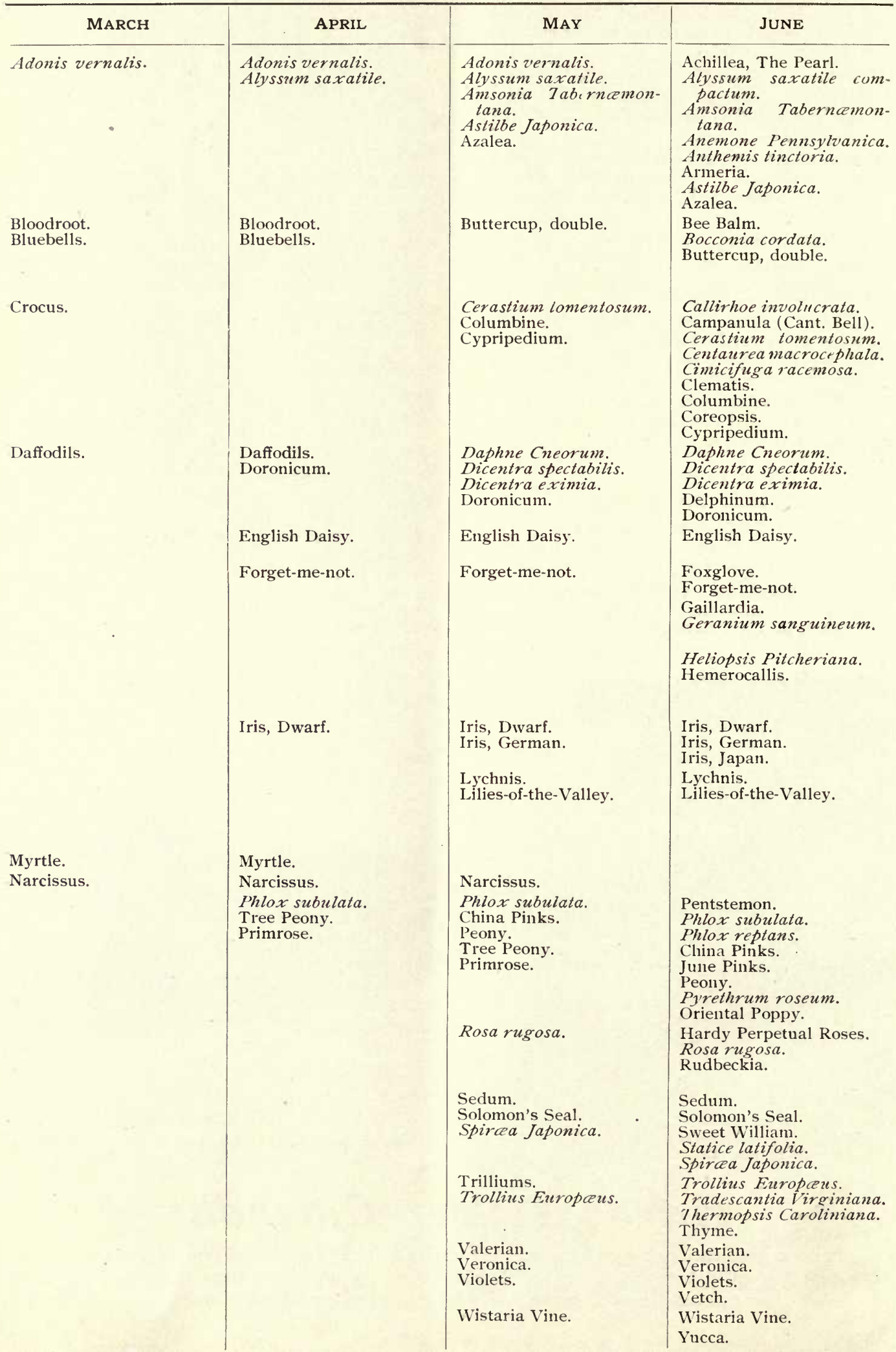




\section{HARDY FLOWER CALENDAR}

\begin{tabular}{l}
\hline \multicolumn{1}{c}{ July } \\
\hline Achillea, The Pearl. \\
Anemone Pennsylvanica. \\
Anthemis tinctoria. \\
Armeria. \\
Astilbe Japonica. \\
Asclepias tuberosa.
\end{tabular}

Bee Balm.

Buttercup, Double.

Blackberry Lily.

Baby's Breath.

Callirhoe involucrata.

Campanula.

Centaurea macrocephala.

Clematis.

Coreopsis.

Columbine.

Day Lily.

Dicentra eximia.

Delphinium.

English Daisy.

Foxglove.

Gaillardia

Geranium sanguineum.

Golden Glow.

Heliopsis Pitcheriana.

Helianthus.

Hemerocallis.

Hollyhock.

Iris, Japan.

Lychnis.

Lysimachia clethroides. Lilies.

Pentstemon.

Phlox.

China Pink.

Platycodon.

Pyrethrum uliginosum.

Rosa Wichuraiana.

Rosa setigera.

Rosa rugosa.

Rudbeckia.

Sedum.

Sweet William.

Silphium perfolialum.

Spirce Japonica.

Trollius.

Tritoma.

Tradescantia Virginiana.

Thermopsis.

Veronica.

\begin{tabular}{l}
\multicolumn{1}{c}{ August } \\
Achillea, The Pearl. \\
Anemone Pennsylvanica. \\
Anemone Japonica. \\
Anthemis tinctoria. \\
Armeria. \\
Asclepias. \\
Aster, Nova-Anglia.
\end{tabular}

Bee Balm.

Buttercup, Double.

Boltonia.

Blackberry Lily.

Baby's Breatl.

Callirhoe involucrata.

Campanula.

Clematis.

Coreopsis.

Chelone Lyoni.

Columbine.

Day Lily.

Dicentra eximia.

Delphinium.

English Daisy.

Gaillardia.

Golden Glow.

Heliopsis Pitcheriana.

Helianthus.

Helenium.

Hemerocallis.

Hollyhock.

Liatris.

Lychuis.

lespedeza.

Lilies.

Lobelia.

Marshmallow.

Pentstemon.

Phlox.

China Pink.

Platycodon.

Pyrethrum uliginosum.

Rosa rugosa.

Rudbeckia.

Sedum.

Silphium perfoliatum.

Stokesia.

Tritoma.

Tradescantia.

Veronica.

\section{SEPTEMBER \\ Anemone Pennsylvanica. Anemone Japonica. \\ Anthemis tinctoria. \\ Armeria. \\ Asclepias. \\ Aster, Nova-Anglia. \\ Aster, Talaricus \\ Aster, Podophyllum.}

Bee Balm.

Boltonia.

Caltirhoe involucrata.

Cassia Marylandica.

Clematis.

Coreopsis.

Chrysanthemum.

Day Lily.

Dicentra eximia.

Delphinium.

English Daisy.

Eupatorium

Feverfew.

Gaillardia.

Golden Glow.

Helianthus.

Helenium.

Linum.

Lychnis.

Lespedeza.

Lilies.

Marshmallow.

Pentstemon.

Phlox.

China Pink.

Platycodon.

Pyrethrum uliginosum.

Rosa rugosa.

Rudbeckia.

Salvia.

Sedum.

Stokesia.

Tritoma.

Tradescantia.

\section{OCTOBER}

Anemone Japonica.

Anthemis.

Aster grandiflorus.

Callirhoe involucrata. Chrysanthemum.

Day Lily.

English Daisy.

Eupatorium.

Gaillardia

Helianthus.

Phlox.

China Pink.

Platycodon.

Stokesia.

Tritoma.

Yucca. 


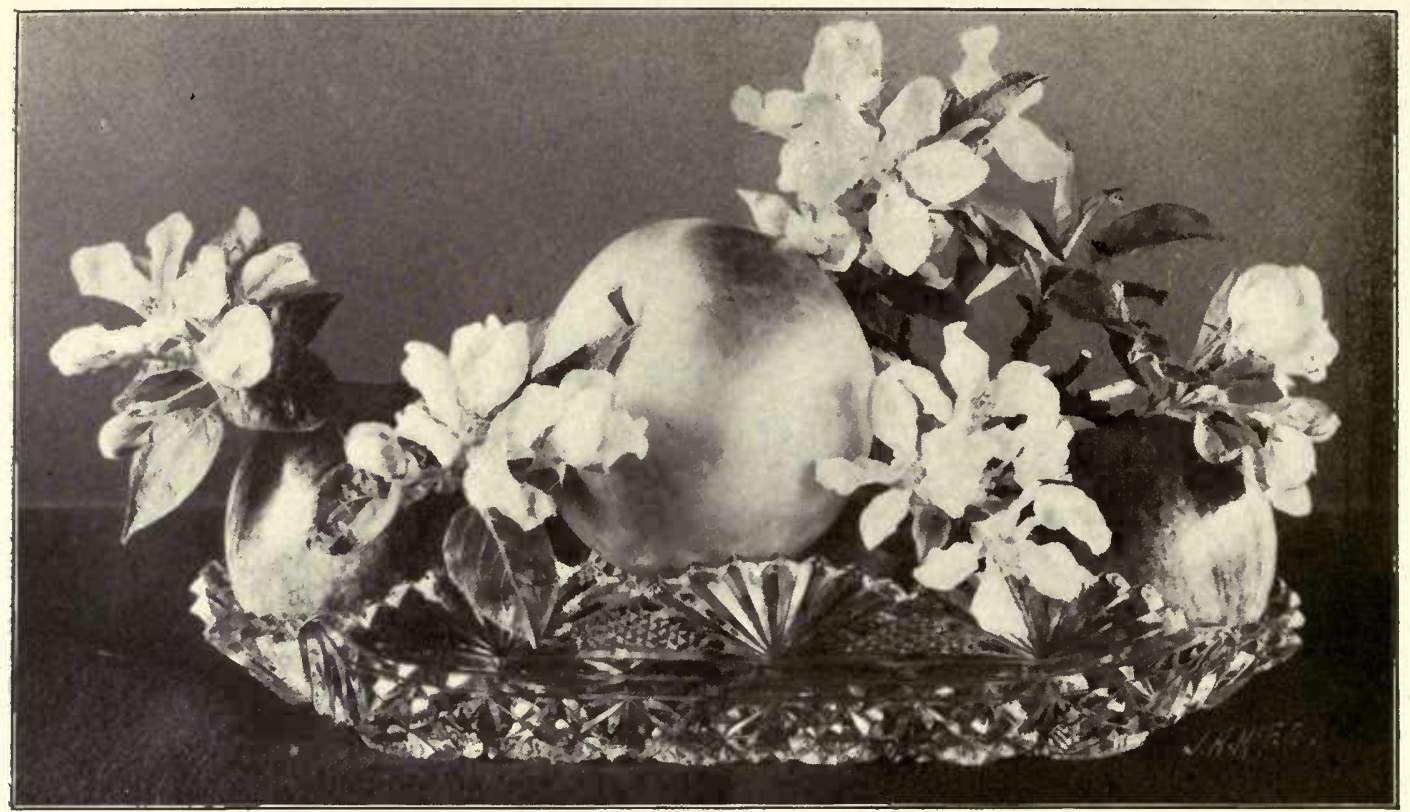

\section{Fruits for Long Island}

\section{A FEW HINTS}

PLANTING.-Cut off broken roots and cut the ends of large roots smooth. Dig a wide hole, deep enough to let the tree stand the same depth as in the nursery. Spread the roots out and pack the soil firmly around them.

PRUNING-Blackberries and Blackcaps. Cut back to near the ground when planted. Cut off the tops of the young shoots in summer when 2 feet high. This will make them branch, produce more fruit, and stand up better. Do not neglect this pruning until the canes are 6 feet high. Allow but 4 to 6 canes per hill. Remove the old canes after fruiting, and the following spring shorten-in the side branches. In a small garden tie to a wire, trellis or stakes.

Red Raspberries. Prune same as above excepting the summer pruning.

Currants and Gooseberries need but little pruning; merely remove the branches over two or three years old.

Apple, Pear, Cherry, Peach, Plum and Quince. When planting, prune to reduce the top by one-half or three-quarters. Cut just above a strong bud. Do not leave opposite branches, that form crotches to be easily broken.

Later Pruning. Thin out the inside of the tree by removing weak branches, water sprouts or suckers, and branches that cross and rub. Some cut back one-half of each year's growth of the peach, on rich soil. If the flower-buds are partly winter-killed, omit this cutting back, as it reduces the flowers and fruit.

Cut all branches close, even if the wound is larger, and paint all wounds over two inches in diameter with coal tar or thick paint. Old decayed cavities should be cleaned out to sound wood, painted and filled with cement. Split crotches should be bolted together at or above the break. We furnish experts for this work.

Grapes. Cut grape-vines back to two buds when planting. Train the two shoots from these buds to a trellis or building, and the shoots from them will bear the following year. The next winter these shoots may be cut back to spurs of one or two buds, or the whole arm cut off to the trunk of the vine, and the new canes tied to the wire as before. During the summer, bearing shoots may be allowed to hang down, or tied to upper wires.

Time to Prune. Most severe pruning should be done between Octcber and April, when the plant is dormant. 
Heading-back too vigorous shoots, and removing undesirable branches, may be done at any tirne during the summer. Storm-damaged trees and decayed wounds may be repaired whenever necessary.

CULTIVATION and FEEDING (Fertilizing). All young fruit plantations should be kept cultivated the same as corn or potatoes; in fact, vegetables may be profitably grown in young orchards. Cultivate once in two weeks or oftener, and especially the day following a heavy rain. This will make a mulch of about three inches of fine earth or dust, that prevents evaporation from the soil. Feed annually with stable manure or complete fertilizers, or both. Trees need a fertilizer rich in potash and phosphoric acid, rather than an excess of nitrogen; therefore, muriate of potash, unleached hardwood ashes, bone-flour and dissolved South Carolina rock are good special fertilizers. Crimson clover is valuable as a green manure, sown in August, before the last cultivating, and plowed under the following spring.

Borers in the trunks of trees should be dug out. Leaf-eating insects are killed by spray of Paris green, I lb. to Ioo gallons of water. Currant-worms are quickly killed by hellebore powder. Leafsucking insects are destroyed by spraying or washing with whale-oil soap or kerosene emulsion. Mildew and other fungous diseases of grapes and fruit trees are prevented by spraying with Bordeaux mixture or ammoniacal solution of carbonate of copper.

FOR SAN JOSE SCALE, which is being generally distributed by birds, use whale-oil soap, kerosene, petroleum, or lime, salt and sulphur wash. For instructions write to the State Agricultural Experiment Station, Geneva, N. Y.

\section{Distances to plant tReEs and plants}

\begin{tabular}{|c|c|c|c|c|c|c|c|c|c|c|c|c|c|c|c|c|c|c|c|}
\hline pples $\cdot \cdots \cdot \cdots \cdot \cdot \cdot$ & & & & & & & & & - & - & & - & & & - $30 \times 30$ & & & “ees & \\
\hline ears, Standard, and Cherries & $\cdot$ & & & & - & & & & - & - & & - $\cdot$ & & & . $25 \times 25$ & & 70 & “" & \\
\hline $\begin{array}{l}\text { "Dwarf } \\
\text { Peaches, Plums and Apricots }\end{array}$ & & & - & & & & & & . & & & & & & - $12 \times$ I 2 & “" & 300 & 6 & “ \\
\hline $1 \mathrm{~ms}$ and Apricots & - & & • & & & & & & · & & $\cdot \cdot$ & & - & & $18 \times 18$ & 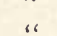 & I 35 & 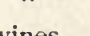 & 16 \\
\hline $\begin{array}{l}\text { Grapes . . . . } \\
\text { Asparagus . . . }\end{array}$ & & & & & & & - & & 4 & & & & & & I0 $\times 16$ & 4 & 275 & hes & \\
\hline ooseberries. & & & - & & - & & & & & & - $\cdot$ & & • & & - $2 x$ & $"$ & 4,250 & plants & \\
\hline oseberries & & & & & & & & & & & & & & & . $2 x$ & " & $5,45^{\circ}$ & bushes & $"$ \\
\hline nd Blackberries & - & & $\cdots$ & & - & & & & & & & & & & - $3 \times 6$ & “ & 2,420 & plants & 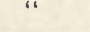 \\
\hline rries . . . . & & & . $\cdot$ & & & & & & •. & & & & & & - $\mathrm{I} x$ & “" & 14,500 & “" & “" \\
\hline
\end{tabular}

Closer planting and pruning is advised for small gardens.

THE VARIETIES ARE GIVEN IN ABOUT THE ORDER OF RIPENING

\section{APPLES}

Price, 5 to 6 feet, $25 \mathrm{cts}$, each, $\$ 20$ per $100 ; 6$ to 7 feet, $35 \mathrm{cts}$. each. Larger trees, 40 to $75 \mathrm{cts}$. each.

In our old and extensive orchards most of the varieties here listed, and many others that have been discarded, have been tested. While some varieties will thrive anywhere under good culture, the loss entailed by planting and cultivating poor varieties is great, and emphasizes the importance of planting tested kinds. Many good varieties will occasionally fail to produce satisfactory crops through lack of culture and fertility, or insects and fungus.

LARGE ORCHARDS. - Those intending to plant large orchards are invited to correspond with us early in the season, before October or March. Low rates for trees of various qualities will be quoted.

\section{SUMMER}

Primate. An excellent early Apple, superior to the Harvest in flavor. Very tender; bright yellow; ripens in July.

Yellow Transparent. A Russian variety of value. Medium size; skin translucent yellow, with waxen surface; flesh yellow ; sprightly acid. July. Usually bears the first year after planting.

Harvest. Medium size, pale yellow; flesh white, tender and juicy; rather acid. Ripens in July.
Red Astrachan. Large, round, deep crimson, which takes a bright polish; flesh juicy. A vigorous, productive tree. Good for early market and dessert.

Sweet Bough (Early Bough). Large, pale yellow ; tender, sweet. An excellent variety for baking.

oldenburg (Duchess of Oldenburg). A Russian variety of value; fruit above medium size, hand. some, yellow, covered with streaks of crimson; flesh tender, juicy and pleasant. August.

\section{AUTUMN}

Gravenstein. Large, round, red and yellow ; flesh firm, brittle, juicy, high flavored, subacid. Tree vigorous and productive. A long time in ripening during August and September. The best market Apple of its season, and deservedly popular.

Wealthy. Medium size; skin oily, dark red; flesh white, fine-grained, juicy, subacid. Tree a free grower and early bearer. Resembles the Fameuse. October and November.

Porter. Large, oblong, bright yellow ; flesh tender, rich, aromatic flavor. A very good fall Apple.

Fall Pippin. Very large, round, rich yellow; flesh yellow, firm, tender, creamy and excellent flavor for dessert or cooking; tree vigorous and productive. An old and well-known variety, more subject to apple-scab than some others It ripens in late autumn and keeps until midwinter. 


\section{AUTUMN APPLES, continued}

McIntosh Red. A good-sized Apple, resembling the well-known and popular Fameuse; flesh tender, white and sprightly. It is too soft for market.

Maiden's Blush. Large, round, pale yellow, with a beautiful red cheek; flesh tender and pleasant, but not highly flavored. Tree a vigorous grower. A very good market sort.

\section{WINTER}

Fameuse (Snow Apple). Small to medium in size, round, deep crimson; flesh snowy white, with crimson streaks, very tender, crisp, spicy and melting. One of the finest dessert fruits. November and December.

Hubbardston (Hubbardston's Nonesuch). Large, handsome, yellow, mostly covered with red; flesh tender, fine-grained, with an excellent and distinct flavor; tree upright and productive. Does not keep after midwinter.

Smokehouse. Large, flat, red and yellow; flesh yellow, firm, juicy and crisp; aromatic. An early and prolific bearer. Widely grown and popular. October to January.

Rhode Island Greening. Large, round, green or greenish yellow; flesh yellow and fine-grained, tender, with a rich subacid flavor. A favorite for cooking. A standard winter Apple. November to March.

Bellflower. Medium to large; pale yellow with blush cheek ; flesh very tender, crisp, juicy, with a delicate spicy flavor; core large. Succeeds best on rather light soils.

Fallawater. Very large, flat; skin smooth, dark green, with dull red cheek; flesh greenish white, coarse-grained, mild subacid. A very strong grower and productive bearer of large, latekeeping fruit, valuable for market and cooking. November to April.

Grimes' Golden. Above medium size ; yellow, with russet spots; yellowish white flesh, with a very agreeable flavor. November and December.

King (King of Tompkins County). A large, handsome red Apple of fair quality. Tree a good grower and moderate bearer.

Spitzenburgh (Esopus). Medium rich red Apple, with crisp yellow flesh, of a spicy acid flavor. A good keeper.

Jonathan. Of medium size; skin yellow, nearly covered with dark red; fine-grained, very tender, and of excellent flavor. It commands a high price on the market. Tree needs careful culture. November to January.

Sutton's Beauty. An Apple from Massachusetts. Skin yellow, striped with crimson; flesh tender, subacid. December to February.

Baldwin. - Large, red, with yellow on one side; crisp, juicy and rich. Tree vigorous and productive. A standard variety. November to April.

Roxbury Russet. Medium or large size, russet; flesh greenish white, crisp, with a fine subacid flavor. Tree a good grower and productive. Keeps late.

Peck's Pleasant. Medium to large ; waxen yellow, with blush cheek; resembles the Newtown Pippin; flesh yellow, fine-grained, crisp and brittle. We regard it as the best-flavored Apple. December to March.
Long Island Russet. A small to medium-sized yellow and russet Apple. The tree is most vigorous and productive, and the fruit keeps till May.

Ben Davis. Medium size; handsone deep red; flesh firm, white, subacid; a good shipper and late keeper; productive, but lacking in flavor. Tree vigorous and early bearer. January to April.

Newtown Pippin. A famous Apple, originating on Long Island. Fruit dull green ; flesh greenish white, juicy, crisp, with fine aroma and delicious flavor; late keeper. Tree a feeble grower. It succeeds well in the heavy loam soil of Jericho, Huntington, Port Washington. January to May.

For home use the following will cover the season: Yellow Transparent, Red Astrachan, Gravenstein, Fall Pippin, Rhode Island Greening, Baldwin, Roxbury Russet.

\section{CRAB-APPLES}

For preserving, jellies and ornament.

Montreal Beauty. Large size of its class; yellow and rich red; flesh rich, firm, acid. September and October.

Transcendent. One of the best early varieties. Golden yellow, with a red cheek. September.

\section{PEARS}

Prices, 5 to 7 feet, 30 cts. to 40 cts. each, $\$ 25$ per 100 : larger trees, transplanted and grown one or two years, with numerous fibrous roots, $40 \mathrm{c}$. to $60 \mathrm{c}$. each.

Summer Doyenne (Doyenne d'Ete). Small ; flesh white, nelting, sweet. Tree vigorous and productive. Ripens in July.

Manning's Elizabeth. Small to medium; yellow, with a red cheek; sweet and sprightly. Our best early dessert Pear.

Osband's Summer. Medium size; yellow, with reddish brown cheek; flesh white, granular, with sweet flavor. Ripens in early August.

Clapp's Favorite. Large, long; yellow, with red cheek; flesh fine-grained, melting and of excellent flavor. It resenubles the Bartlett, but is much earlier. It should be picked a week before it would ripen on the tree, and be ripened in the house, otherwise it softens at the center. A valuable Pear that should be in every garden. It ripens in August.

Bartlett. A standard sort too well known to need description; bears young and abundantly. It ripens in August and September, and is an excellent variety for dessert and preserving.

Tyson. Medium size; bright yellow; flesh juicy, sugary and aromatic. A regular bearer.

Belle Lucrative. Above medium size; melting, very juicy and sweet. Subject to fungons attacks. September.

Boussock. Large; russet-yellow; flesh melting and of excellent flavor. The tree is large and vigorous. A valuable market Pear. October.

Sheldon. Large; greenish russet and red; flesh coarse, of fine flavor. Productive. Septenuber and October.

Howell. Rather large; waxen yellow anci russet; flesh granular, with a rich subacid flavor. A profuse bearer, and good for preserving. 
PEARS, continued

Seckel. Fruit small; brow1l, with a deep red cheek; flesh very fine-grained, sweet and juicy ; the richest and highest flavored Pear known. Tree of small size and slow growth. Farly to midautumn.

Anjou. Large ; green and russet; flesh white, buttery, with a rich, vinous flavor. Very productive. October and November.

Bosc (Beurre Bosc). Large, long; russet; flesh buttery, juicy, with rich and excellent flavor. It requires clay soul to reach perfection. November. $50 \mathrm{cts}$.

Kieffer. I arge to very large; yellow-russet, with red cheek; very juicy and of a peculiar flavor disliked by some when not properly grown and ripened. The general appearance of the tree is distinct; its growth is exceedingly vigorous, with dark, lustrous foliage. Some ILong Island farmers have found it very profitable for market. It should be severely thinned when the fruit is small. December. Low rates in quantity.

Winter Nelis. Medium; dull russet; flesh finegrained, with rich, sprightly flavor. November and December. 50 cts.

\section{DWARF PEARS}

Price, two and three years old, $40 \mathrm{cts}$. each

The following varieties, grafted on quince roots, succeed as dwarfs, and are valuable for small gardens :

Clapp's Favorite and Bartlett. See description of these varieties under Standard Pears.

Louise Bonne de Jersey. A large, beautiful yellow Pear, with a red cheek; rich flavor. Vigorous grower and an abundant bearer. September and October.

Angouleme (Duchesse d'Angouleme). One of the largest of the good Pears. Oct. and Nov.

Anjou. See description under Standard Pears.

\section{PEACHES}

Price, 4 to 5 feet, 15 cts. each, $\$ 12$ per 100 ; 5 to 6 feet, 20 cts. each, $\$ 15$ per 100 . 2-year, transplanted. $25 \mathrm{cts}$. to $40 \mathrm{cts}$. $e$ ach.

For early bearing and general satisfactory results, no fruit tree exceeds the Peach. They will commence to bear sixteen months after planting, and produce abundant crops nearly every year. Fertilize with wood ashes or potash. A new supply of trees should be planted every two or three years, in order to keep up a succession. This list is nearly in order of ripening.

The same skill that has developed the vegetable growing of Jong Island to its high position will make the poorer land of Long Island profitable with Peaches. The local market is never supplied. The railroads should coöperate to develop an extensive Peach industry on the hills of Suffolk county.

Early Rivers. Large, white, juicy.

Champion. Large, creamy white and juicy. Said to be one of the most frost-proof of Peaches. An excellent earty Peach.

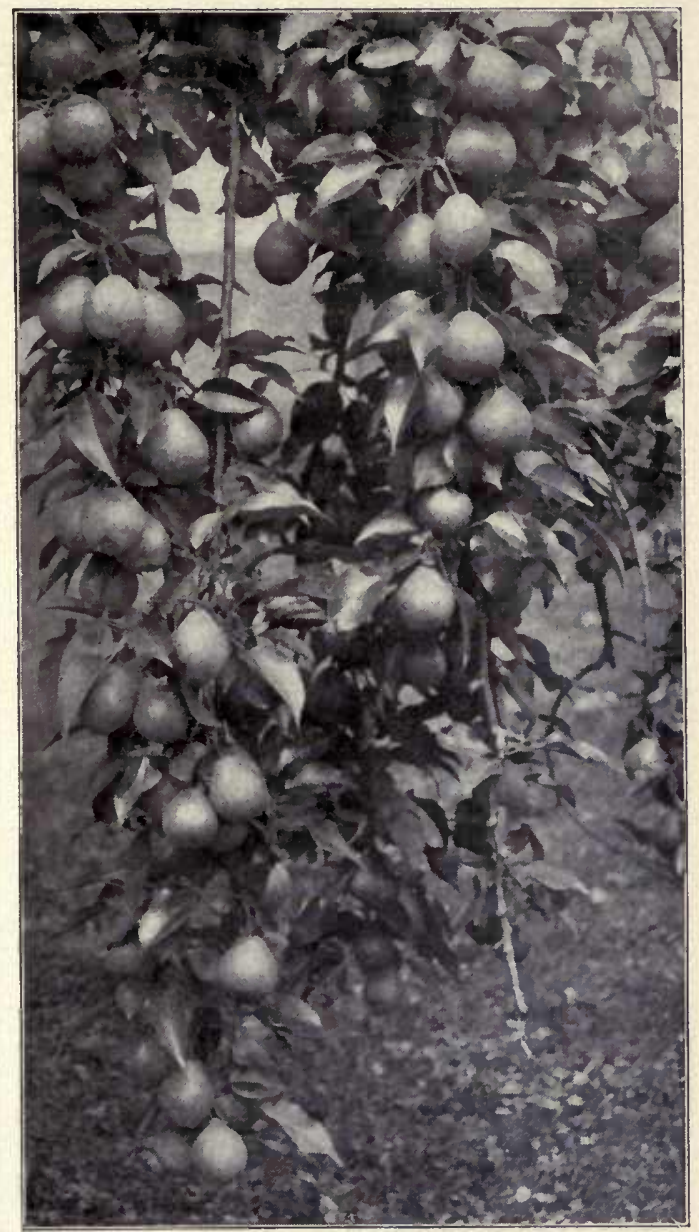

Branch of Kieffer Pears.

Mountain Rose. Above medium size, round, white. 'Tree thrifty and an abundant bearer.

Yellow St. John. A large yellow freestone, with a deep red cheek ; flesh yellow, sweet, juicy and high flavored. One of the best early Peaches.

Early York (Honest John). A large, beautiful white Peach. A valuable variety.

Foster. A very large Peach, resenbling Crawford's Early, but earlier in ripening.

Crawford's Early. A magnificent, large, yellow Peach of good quality ; tree vigorous and productive. September.

oldmixon. A productive variety that succeeds well in all localities. Jlesh white, red at the stone, flavor excellent. A favorite camning variety.

Crosby. Medium size; bright yellow flesh, firm, sweet and good. It has stood many severe winters in New England.

Wheatland. Considered an improvement on Crawford's Late, and ripening just in advance of it.

Stephen's Rareripe. I,arge, oblong; white flesh, red skin. A heavy bearer. October.

Reeves' Favorite. Large; yellow, juicy, melting, with a vinous flavor.

Elberta. One of the finest yellow Peaches; very large, handsome, juicy and of fine flavor. 
PEACHES, continued

Susquehanna. Very large; rich yellow, with a beautiful red cheek. A handsome and valuable variety for table use or canning.

Crawford's Late. A standard variety. Large; yellow, red at the stone.

Stump the World. Mediun size; creamy white, juicy and high-flavored. Unexcelled for preserving.

Chair's Choice. Large, yellow, with red cheek; flesh firm and of good quality. The large Peach growers of Long Island report that this is a valuable variety.

Morris White. Medium size, creamy white skin; flesh white throughout, juicy, sweet. Good for preserving.

Hill's Chili. Medium size, yellow, hardy, productive.

Globe. Large, golden yellow, firm, sweet and delicious. A rapid grower and good bearer.

Smock. Medium to large, yellow, moderately juicy to dry; very late; sometimes it does not ripen here.

\section{JAPAN PLUMS}

Price, 30 to $40 \mathrm{cts}$. each.

This new class of fruit we have thoroughly tested, and strongly recommend its planting in gardens and orchards. After one or two years the trees bear heavy annual crops of delicious fruit.

The peculiarly desirable features presented by these Japanese Plums on a conservative estimate are earliness and great productiveness. The quality is good when well thinned and ripened, but not always equal to the best of the common Plums.

They are the best Plums for Long Island, and should be largely planted.

Red June. A medium to large vermilion-red Plum; very showy. Flesh moderately juicy, of subacid, pleasant quality, but not so rich as some others. The best early Plum.

Abundance. Medium to large, globular; yellow, mostly covered with red; flesh firm and juicy, sweet and good when fully ripe. The tree is

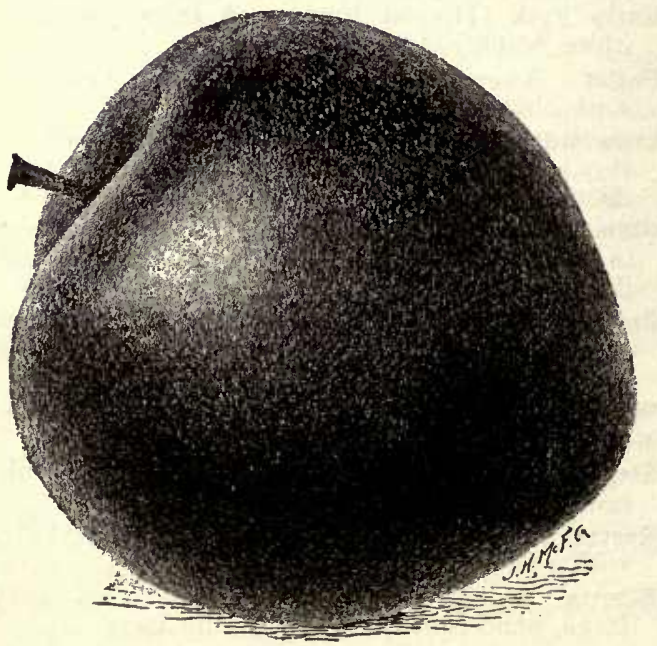

very productive, and the loads of fruit that young trees carry astonish all who see them. The fruit should be severely thinned out and the branches tied up. Ripens in early August.

Burbank. Medium to large; yellow, with red cheek; flesh firm, rich and sugary; the best flavored variety we have ever tested. The tree is very productive. Ripens last of August.

Wickson. The largest Japan Plum. Maroon-red; flesh firm and long-keeping, of good quality. A promising new variety.

Hale. A handsome, globular, red-speckled Plun. Flesh soft and juicy, of good quality and peachlike flavor. Tree a good grower and productive. A very promising new variety, just introduced.

Satsuma. Large; very dark red; flesh blood-red, acid, of fair quality when fully ripe. Productive and late.

October Purple. A reddish purple Plum of large size; good quality. Its late ripening and good keeping qualities make it one of the desirable varieties.

\section{EUROPEAN PLUMS}

The varieties of the common or European Plum (Prunus domestica) do best on heavy land, but will grow well on any soil, if given applications of ground-bone and potash.

Bradshaw. Fruit large, oval ; reddish purple; fleslı yellow, rather coarse, juicy and good. Tree very vigorous, and has good foliage.

German Prune. Fruit long-oval; purple, with white bloom ; flesh green, sweet. Tree a poor grower.

Green Gage. Round, small, green fruit; the flavor is exceedingly sweet and rich, unequaled by any other. A small, compact tree.

Lombard. Medium to large; dark red; flesh deep yellow, of pleasant flavor, but not rich. The tree is one of the most vigorous of the Plum family, and is productive and well adapted to light soils.

\section{PERSIMMON, AMERICAN}

A large, handsome tree with lustrous leaves Skin and flesh of fruit brick-red, soft and sweet after frost. Native to wet ground on Long Island. We are testing new named varieties.

\section{CHERRIES}

Price, 40 cts. each.

The Cherries are anıong the most satisfactory fruits to raise for home use. They grow well on all Long Island soils, and annually set large crops. Cherries may be divided into four groups :

HEARTs, with soft flesl, heart-shaped, sweet. The dark red varieties are in this class. 'This and the next are sometimes called "Oxhearts."

Bigarreaus, with hard flesh, heart-shaped, sweet, mostly of the lighter colors.

Dukes. I,ike the above, but with acid or subacid fruit.

Morellos (Sour Cherries). Flesh sour ; tree smaller than the others, with slender branches and narrow leaves. 


\section{HEART CHERRIES}

Governor Wood. Large, heart-shaped yellow fruit, marked with red; sweet juicy flesh. A rich and delicious Cherry.

Coe's Transparent. Medium size; amber color, with a red cheek; very tender, melting, sweet. Ripens early, just before Tartarian. Tree thrifty,

Black Tartarian. Fruit very large, nearly black. Flesh dark purple, firm, sweet and juicy, with a small pit. Tree a rapid grower. The long, upright branches of this variety, hung with luscious fruits, are a beautiful sight.

Downer's Late Red. Medium size ; red and amber ; flesh tender, melting, rich; not good till fully ripe. This variety is late, and hangs on the tree after it is ripe without decaying; as many other kinds do. Ripens first half of July. The birds molest it but little, as it ripens about the tine of the wild Mazzards.

\section{BIGARREAU CHERRIES}

Rockport. Large; clear red, shaded with anber; flesh firm, juicy, sweet, rich. Ripens early. Tree upright and vigorous.

Yellow Spanish. Very large, often an inch in diameter; waxen yellow, with a light red cheek; flesh firm, and of fine, rich flavor.

Napoleon. Very large, heart-shaped, pale yellow and amber, shaded with deep red. Flesh very firm and of good flavor. Ripens after midseason. Tree vigorous and productive.

Windsor. Large, mottled red; very firn and juicy, of good quality. The tree is upright, vigorous and a heavy bearer. A desirable late Cherry, as it hangs a long time and rots but little.

Mercer. A very dark red Cherry ; productive and early; of good flavor, and not liable to rot.

Schmidt's. The largest of all the black Bigarreau Cherries. The fruit grows in clusters; the flesh is dark, tender and very juicy.

\section{DUKE CHERRIES}

Mayduke. . Large, round, red, changing to nearly black when ripe. Flesh very juicy and melting; acid. Quite early.

\section{MORELLO CHERRIES}

This class is excellent for cooking and preserving.

Early Richmond (English Pie Cherry). Sinall to medium in size, beautiful red, very juicy, acid. Tree productive.

Montmorency. Large, round, bright red; moderately sour. A good bearer, which fruits young. One of the best of its class.

Morello (English Morello). Medium to large ; dark red to nearly black. Flavor a rich acid, with some astringency, making it desirable for cooking. It ripens after midsummer.

\section{MULBERRIES}

\section{5 cts. to $\$ 1$ each.}

Downing Everbearing. Large, black, sweet and pleasant fruit. A handsome shade tree.

New American. Fruit of the best flavor. Ripens from June to September.

\section{GRAPES}

Price, 2-year old, 15 to $25 \mathrm{cts}$. $\theta \mathrm{ch}, \$ 10$ to $\$ 20$ per 100. Extra-size, 3 years old, 30 cts. each.

Grapes are easily grown by any one, and on the smallest bit of ground. There is room along any garden fence or walk for a dozen vines to furnisl this most delicious of fruits for home use, from August until November. Training on the sides of buildings is recommended, as the fruit is less liable to decay.

The vines will fruit under unfavorable conditions, but good culture, pruning and spraying pay, if fruit of best quality is desired. Commercial grapegrowers find it necessary to spray with Bordeaux Mixture, occasionally during the growing season, to keep in check mildew on the foliage, and rotting of the fruit. Protecting the clusters, as soon as formed, by pinning over them 2-pound paper bags, prevents injury from fungus, storm and bircls.

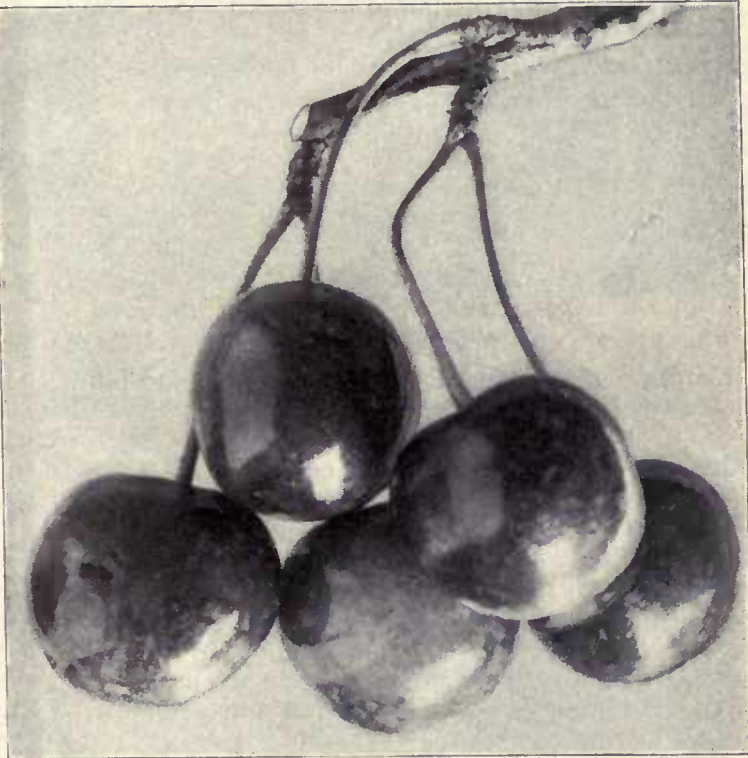

Cottage. Bunch sinall ; berry large, black; pulp tough and sweet. A good early black variety.

Moore's Early. Large ; black ; good flavor.

Delaware. This early Grape is very distinct from all others, and worthy the care necessary to grow it. Bunch and berry small; skin thin, light red, translucent ; exceedingly sweet and aromatic.

Brighton. Bunch medium to large ; berries above medium in size, dark red; flesh tender, with small pulp, of very good quality. Vine vigorous, productive. A hybrid, partly, of the European Grapes. In the foggy climate of Long Island it mildews, and is worthless unless sprayed with Bordeaux mixture.

Lady. Bunch and berry medium size; greenislı yellow; tender and sweet; early.

Martha. Berries large, pale yellow; sweet and juicy, slightly foxy in flavor. A good early white Grape.

Niagara. Bunch large, compact; berry large; skin pale yellow or white; flesh tender and sweet; vine vigorous and productive. The handsomest white Grape, ripening in midseason with Concord. 


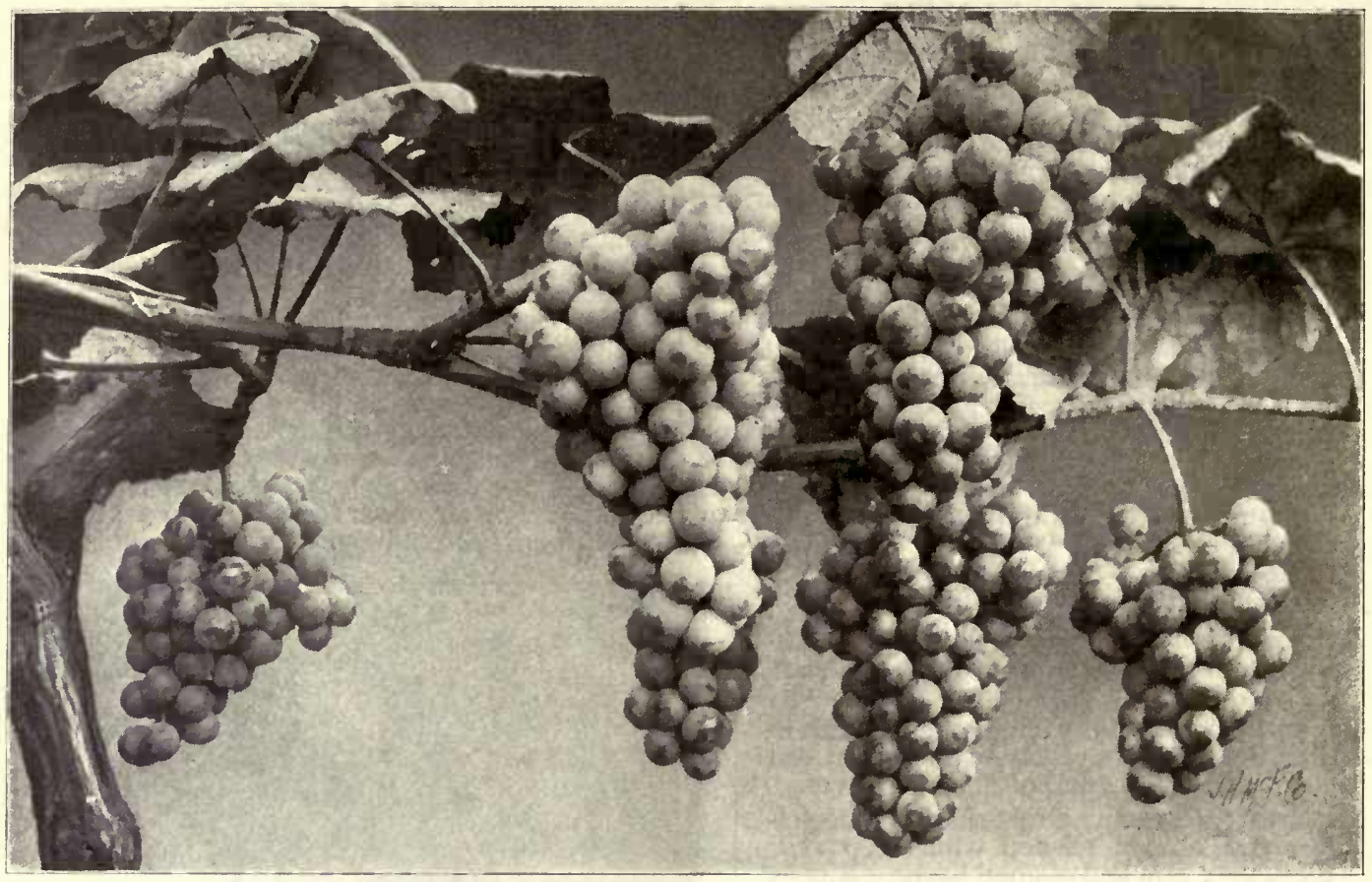

GRAPES, continued

Worden. Berry very large, black; skin and pulp tender and sweet. Ripens ten days ahead of Concord, and is superior in quality.

Green Mountain. Berry of medium size, white; pulp tender, juicy, very sweet and rich.

Diamond (Moore's Diamond). Berry large, white, translucent ; flesh juicy and alnıost without pulp; quality very good. Vine vigorous and productive.

Concord. Bunches compact, large; berries large ; skin black and tender; flesh juicy and sweet. Extreme hardiness, vigor, productiveness, aud the fine appearance of its clusters have rendered Concord the most popular Grape.

Herbert. Berry medium size, black ; tender, sweet and rich.

Salem. Bunch and berry large, dull red; tender, of good flavor.

Agawam. Bunch and berry large, dull reddish brown; flesh tender.

Catawba. Berries large, deep coppery red; juicy, sweet and aromatic. Too late to ripen here except in sheltered places or near water.

Pocklington. A light golden yellow Grape of good culality, ripening after the Concord. A strong grower.

\section{GOOSEBE,RRIES}

Price, 2-year-old bushes, $\$ 1.50$ per doz.

Gooseberries thrive in any garden soil, and are very satisfactory for home use.

Downing. Medium to large, pale green; very good; bush upright, spiny, productive.

Chautauqua. Bush very vigorous. Fruit large, smooth, translucent. Sweet and productive.

Industry. The best foreign variety. Berry very large, dark red. Bush vigorous, healthy and procluctive. $\$ 2$ per doz.

\section{CURRANTS}

Price, 2-year-old bushes, $\$ 1$ per doz.

Currants are easily grown, and are naturally fruitful. The worm is readily controlled by hellebore powder.

Cherry. Very large, dark red berries; clusters moderately short; quite acid.

Versailles. Large, closely resembling Cherry, but slightly less acid; bunches long; productive and valuable.

Fay's Prolific. Very large berry; sprightly and acid; on long stems; easily picked. A most popular variety.

White Grape. Large, beautiful white berry ; bunches short; quality excellent. A very pleasant Currant to eat off the bush, as it is less acid than the others.

Victoria. A prolific early variety. Berry smaller than the others; of good quality.

Black Naples. I Large black bunches; berries small, with a strong musky flavor. Valuable for cooking and jams.

\section{RASPBERRIES \\ Price, 60 cts. per doz., \$4 per 100}

The plants should be set in rows 6 feet apart and 3 feet apart in the row.

\section{RED AND YELLOW RASPBERRIES}

Miller's Red. Berry large, firm, bright red.

Marlboro. Bright scarlet fruit of large size. Early.

Cuthbert. Very large, pointed, deep red berries of delicious flavor. This beantiful variety should be planted largely. Ripens nidseason to late. 


\section{RED AND YELLOW RASPBERRIES, conlinued}

Shaffer's Colossal. Very large, dull purplish berries, soft and rather acicl. It is the most prolific and vigorous variety we have tested.

Columbian. A new variety, resembling the last, but sweeter.

Golden Queen. Yellow, soft, juicy, sweet fruit. Resembles Cuthbert in form and flavor, and therefore is an excellent dessert variety.

\section{BLACK-CAP RASPBERRIES}

These ripen earlier than the red kinds, and folJow Strawherries.

Souhegan. Fruit large and handsome; plant a strong grower and hardy. Ripens early.

Gregg. One of the largest of the black-cap family ; truit large, black, with a slight bloom ; moderately juicy, sweet and rich. Ripens late and evenly.

\section{BLACKBERRIES}

Price, 50 cts. per doz., $\$ 4$ per 100

Being easy to grow, Blackberries are a valuable fruit for home use. As they ripen from early July to the middle of August, they complete the season of small fruits until the peaches begin to ripen. To avoid too strong a growth and straggling habit, the ends of the shoots may be cut off at 3 feet in midsummer. Plant $6 \times 3$ feet.

Lucretia Dewberry. Large, coreless, juicy; sweet fruit; most delicious for the table. Ripens before all the others. A running Blackberry that can be trained to a trellis.

Erie. A valuable new variety; large, very early and productive. Desirable as a market berry.

Eldorado. Large berries, borne in large clusters ; vines are vigorous and hardy. One of the best for table use.

Early Harvest. Of medium size, good quality and prolific; very early: It is firm, and therefore a good shipper.

Agawam. A large berry of excellent flavor. Hardy and productive.

Snyder. Berries of medium size, nearly globular, of grood flavor; very hardy:

\section{STRAWBERRIES}

Price, $\$ 1$ per 100 ; in Aug. and Sept. $\$ 2$ per 100.

A garden without Strawherries is incomplete. If Strawberry plants are put out in August and Septemher they will bear fruit the following June. They may be planted in A pril and May, and each plant allowed to make a dozen or more runners and young plants, which bearfreely the follow- ing season. The beds had best be allowed to fruit only two years and then be renewed. Free cultivation should be followed the first year, and the plants covered with straw, manure, or salt hay for the winter. In spring, as the growth commences, this litter may be raked off between the rows to form a mulch, which prevents the growth of weeds and conserves the moisture, as well as protects the ripening berries from the soil. Clippings from the lawn make an excellent mulch for this purpose. By planting four or six varieties, early, medium and late, and giving them good cultivation, the fruiting season will extend from the last week in May to the first week in July.

PER. indicates perfect-flowered.

IMP. indicates imperfect-flowered. Plant with perfect-flowered varieties near.

Excelsior. Per. A firm, productive, high-colored berry; the chief quality is earliness.

Sharpless. Per. Very large, conical or wedgeshaped; white at the tip when not fully ripe; good flavor.

Bubach. Imp. Fruit of largest size and excellent flavor. A prolific grower with vigorous foliage. A standard sort.

Bismarck. Per. This resembles the Bubach in its excellent qualities, and is slightly smaller.

Beecher. A vigorous, strong-growing variety with healthy foliage. Good flavor and size.

Glen Mary. Per. A long, tapering fruit of mild, sweet flavor.

Clyde. Per. Fruit large, abundant, mild flavor. Foliage not so strong as some others.

Nick Ohmer Per. A vigorous grower; handsome berries of good market quality.

Gandy. Per. One of the latest, if not the latest in cultivation.

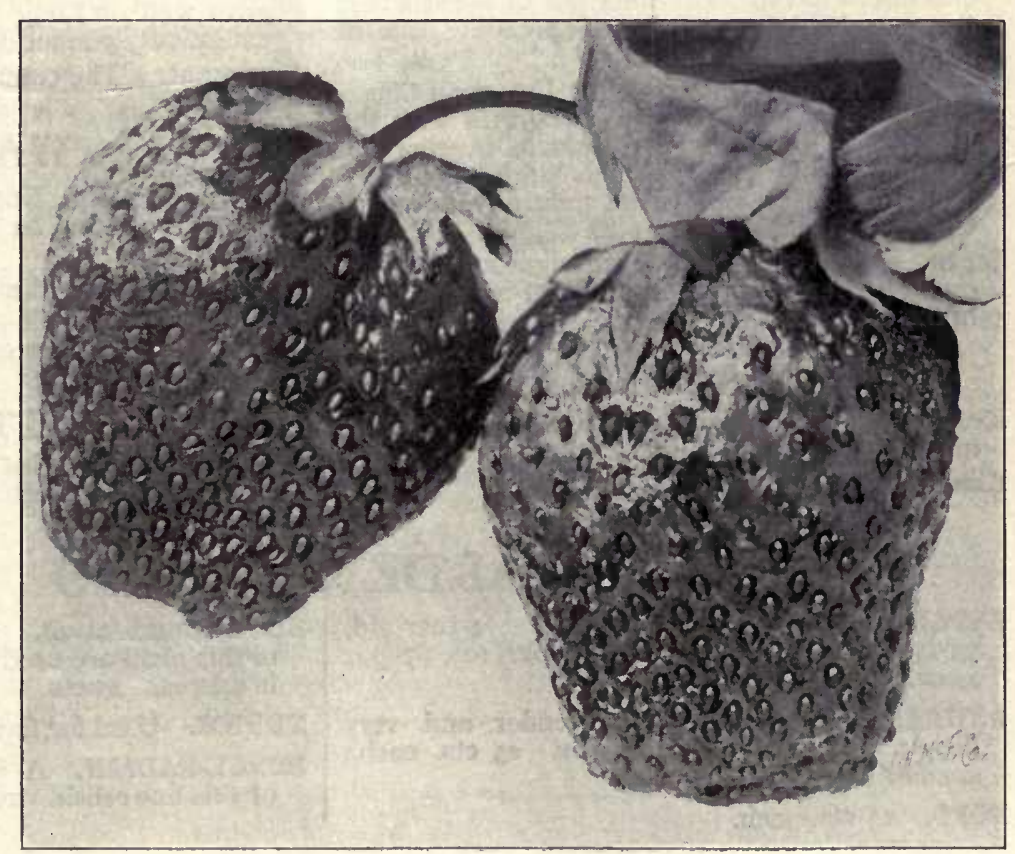




\section{Nut Trees}

In rural and suburban districts, the great economic possibilities of growing edible Nuts are but vaguely understood. They can often be planted along fence lines where they will not affect farming or gardening operations, and later will become a profitable source of income, either in the market or for the owner's use. The United States is importing vast quantities which might he raised at home with profit and credit. American Chestnut sprout growth is easily and cheaply grafted with more valuable sorts. These sorts bear early and abundantly.

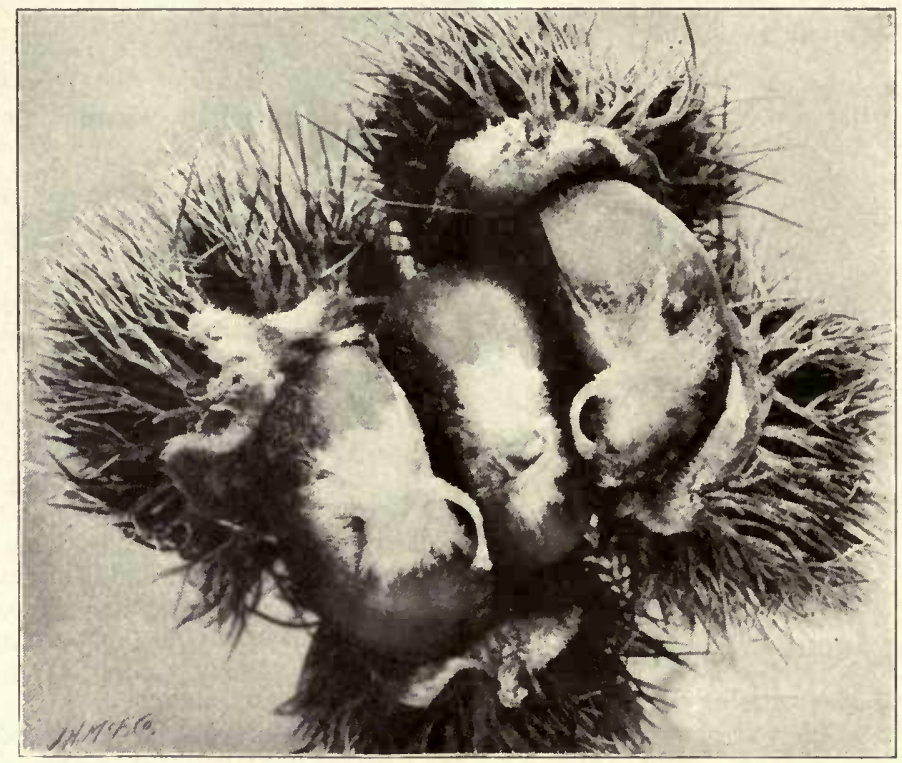

\section{CHESTNUTS}

American. Castanea Americana. The only species of our forest. The nuts are of finest sweet flavor. An immense, broad-spreading tree in the open. Plant 60 feet apart.

Paragon. A variety of Spanish or European Chestnut which is hardy, possibly a hybrid with the American. It is very precocious, bearing the year after grafting. The nut is large and of very good quality. It is the most uniformly successful Chestnut in the United States.

Japan. Nuts very large. Tree vigorous and productive, even when young. Plant 20 feet apart in the orchard.

\section{FILBERT, or HAZELNUT}

Kentish Cob. The large English variety. It grows and fruits well-here. 25 cts. each.

American. Our native Hazelnut.

\section{HICKORY}

Shagbark. Shell thin; meat of good flavor. These grow well on Long Island, and should be more extensively planted for their excellent nuts.

Mockernut. The common native Hickory of Long Island.

\section{WALNUT}

English. Madeira Nut. There are a number of productive trees on Long Island. Tree tender while young.

Japan. Similar to the English, but smaller. Tree vigorous and hardy. \$I.

Black. Nuts large, rough, black; kernel rich and oily.

\section{BUTTERNUT}

Nuts long; kernel of rich flavor. Plant in deep, moist soil for best results.

\section{GARDEN PLANTS}

ASPARAGUS, Conover's Colossal. I-year-old, 75 cts. per roo; 2-year-old, \$1 per 10o, \$7 per I, 000 .

RHUBARB, Linnæus. Early, tender and very large ; possessing a rich flavor. 25 cts. each ; smaller roots, 15 cts.

HOPS. I5 cts, each.
SAGE, Broad-leaved. The tender leaves and tops of this plant are used in sausage, in stuffing, and in sauces. $25 \mathrm{cts}$.

THYME. Used for flavoring. $25 \mathrm{cts}$, each.

HORSE-RADISH. A few roots will give a supply of this fine relish. Io cts. 


\section{Planting a Tree}

HOLES.-Dig wide, deep holes. If the subsoil is poor, dig $2 \frac{1}{2}$ feet deep, and fill the bottom witl a foot of good soil mixed with one-fourth rotted manure.

TRIMMING.-Trim as shown in the picture, cutting back half of last year's growth on the ends of the main branches. Cut ont most of the inside twigs. Leave some buds on every branch. Cut close to a bud or side branch.

Trim Shrubs by removing the old or largest shoots. Do not trim to a round form.

RO0TS.-Avoid breaking by rough handling. Cut smooth the broken roots, as at $\mathrm{A}$, and spread roots in natural position the same depth as before. Pack the soil firmly uncler and between the roots, leaving no air spaces. Soak the ground thoroughly.

MULCH.-Cover ground with a mulch of strawy manure, leaves or salt hay, or keep a dry, fine earth-mulch by hoeing 4 inches deep and wider than the roots extend, once in two weeks, all summer, especially a day after heavy rains or watering. The next spring dig in the mulch, add fertilizer and more nulch.

FERTILIZERS.-Mánure is not a complete plant-food. Apply on top or mix in the soil, but not against the roots, one quart of fertilizer, which should contain 5 to ro per cent of potash. Woodashes and bone-flour are excellent. Avoid too much manure, as it may rot the roots.

WATER. - Water once a week, or once in two weeks, from May to August, by soaking the ground thoroughly with half a barrel of water, unless there are heavy and frequent rains. Over-watering and too frequent watering often kills trees.

Keep down weeds. A few weeds will take up more food and water than

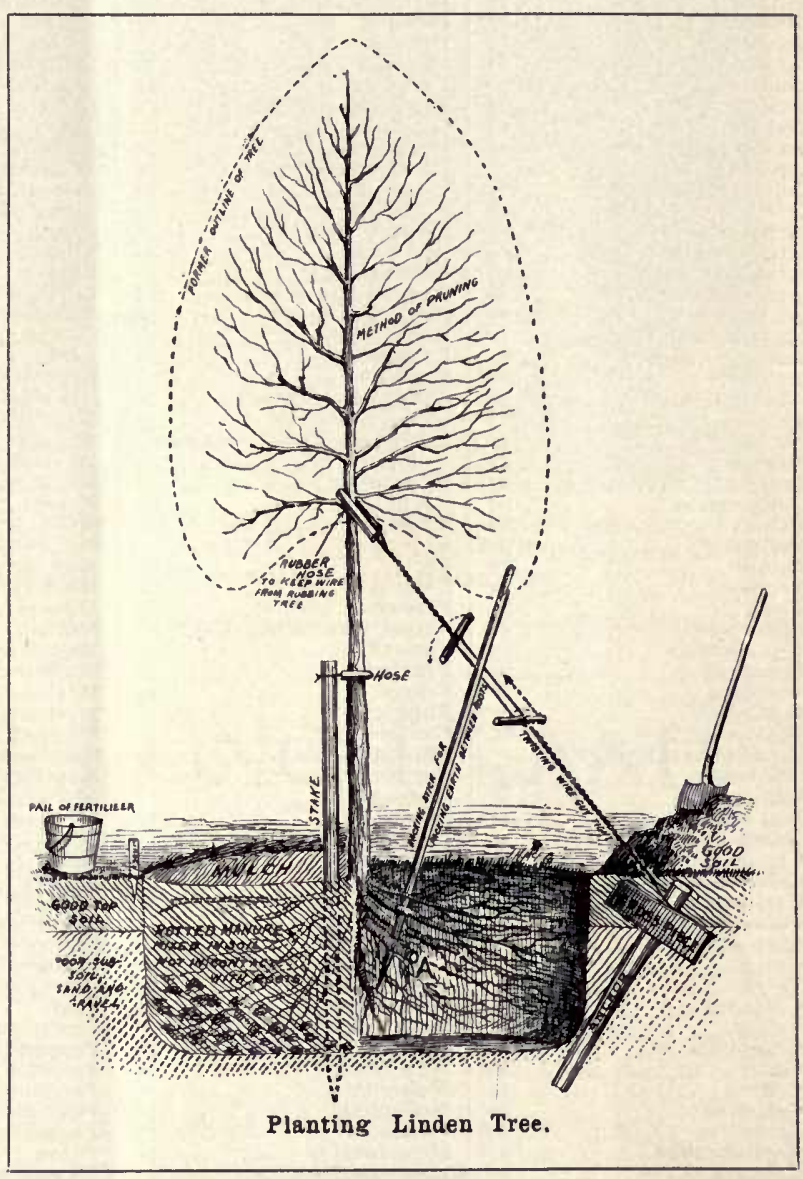
the tree.

HEELING-IN. - To heel-in, or temporarily plant trees on arrival, dig a trench large enough to contain all the roots and place the trees in it in a slanting position, spread out the roots, pack earth around, and water. Covering the ground with a mulch of leaves or litter will be found to be very beneficial to them.

STAKES. - Stakes or guys are needed only with tall or large trees, or those with poor roots. A tree of the size shown, with good roots, needs no stake or wire. For larger trees, rig three or four double wire guys, and twist tight, as shown. For smaller or slender trees use a $3 \times 3$-inch stake, running it up into the top if necessary, and fasten closely to the tree by cord and hose or burlap bands. To protect from horses on the street, place galvanized wire cloth ( $\mathrm{r}$-inch mesh) around the tree and nail it to the stake.

EVERGREENS. - Evergreen tree roots must not be allowed to dry out in the least. If possible, select a foggy time for moving them, and in doubtiul cases, set a barrel of water near and sprinkle the tops several times a day for a week or two. When carting trees, use blankets or sail-cloth to cover the roots. 


\section{INDEX}

\begin{tabular}{|c|c|c|}
\hline PAGE & & PAGE \\
\hline Abies ................ & Cypripedium ..........69 & Juglans ............... 36 \\
\hline Acacia $\ldots \ldots \ldots \ldots \ldots \ldots \ldots \ldots \ldots$ & Daphne............. 54,70 & Juniper... \\
\hline Acer $\ldots . . . \ldots \ldots \ldots .29,50$ & Day Lily ............... & Juniperus. \\
\hline chillea $\ldots \ldots \ldots \ldots \ldots \ldots 67$ & Deciduous Trees ........ & Kadsura Tree................23 \\
\hline dam's Needle ..........75 & Deciduous Trees, Mo & Kalmia ............... 55 \\
\hline onis ...............67 & $\ldots .18$ & Kentucky Coffee Tree... \\
\hline Esculus ...........26, 49 & Delphinium..... & Kerria .. \\
\hline Akebia $\ldots \ldots \ldots \ldots \ldots \ldots \ldots 5^{8}$ & Deutzia............. & hofia ............ \\
\hline ea ..............46, 7r & Dianthus .......... & reuteria ..........26 \\
\hline sum $\ldots \ldots \ldots \ldots \ldots \ldots 67$ & . . ..........70 & $\ldots \ldots \ldots \ldots 6^{6 r}$ \\
\hline psis $\ldots \ldots \ldots \ldots \ldots 6$ 6 & .53 & dsu Vine.............6 \\
\hline 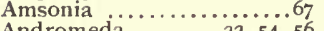 & .70 & $\ldots \ldots \ldots \ldots \ldots$ \\
\hline$a \ldots \ldots 22$ & $\ldots \ldots \ldots \ldots 34$ & $\ldots \ldots \ldots \ldots \ldots$ \\
\hline $\begin{array}{c}\text { emone } \\
\text { gelica } \\
\text { Tree.................49 }\end{array}$ & $\ldots \ldots \ldots \ldots 24.40$ & \\
\hline themis $\ldots \ldots \ldots \ldots \ldots \ldots 67$ & $\ldots \ldots \ldots \ldots \ldots \ldots$ 7o & Lemon Thy \\
\hline es $\ldots \ldots \ldots \ldots \ldots$ 22, 79 & p........74 & Lespedeza.. \\
\hline legia ...........68 & $\ldots \ldots \ldots \ldots$ & $\ldots \ldots \ldots \ldots \ldots{ }^{6}$ \\
\hline .................. 49 & .48 & Ligustrum. \\
\hline & Elder & Lilac....... \\
\hline nia ............59 & .25 & $\ldots \ldots \ldots \ldots 7^{2}$ \\
\hline$\ldots \ldots \ldots \ldots \ldots \ldots, 68$ & $\ldots 34$ & $\ldots \ldots \ldots \ldots \ldots 27$ \\
\hline a ...........68 & $\ldots 74$ & bar...........28 \\
\hline ias ..............68 & se.........74 & lendron............35 \\
\hline$\ldots \ldots \ldots \ldots \ldots 22$ & $, 55,59$ & $t \ldots \ldots \ldots \ldots \ldots \ldots$ \\
\hline . $\ldots \ldots \ldots \ldots$ & .70 & \\
\hline$\ldots \ldots \ldots \ldots \ldots$ & & $\ldots \ldots \ldots$ \\
\hline ia $\ldots \ldots \ldots \ldots \ldots$ & $s \ldots . . . .3$ & $\cdots \cdots \cdots \cdots$ \\
\hline ia $\ldots \ldots \ldots \ldots \ldots \ldots$ & $\begin{array}{l}\text { en Trees .........3 } \\
\text { en Trees, Moving }\end{array}$ & Mahonia............2 \\
\hline 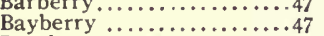 & $\begin{array}{l}\text { en Trees, Moving } \\
\ldots \ldots \ldots \ldots \ldots \ldots . \ldots \ldots\end{array}$ & Maidenhair Tree............25 \\
\hline$\ldots \ldots \ldots \ldots \ldots \ldots 2_{22}$ & $\ldots \ldots \ldots \ldots 4^{8}$ & Maple..................29 \\
\hline ida $\ldots \ldots \ldots \ldots 68$ & $\ldots \ldots \ldots 22$ & .73 \\
\hline$\ldots \ldots \ldots \ldots 68$ & $\ldots \ldots \ldots 70$ & Mint... \\
\hline$\ldots \ldots \ldots \ldots .47,56$ & ........7o & $\ldots \ldots \ldots$ \\
\hline$\ldots \ldots \ldots \ldots \ldots \ldots 75$ & $\ldots \ldots 40,65$ & Mist Tree.. \\
\hline$\ldots \ldots \ldots \ldots \ldots \ldots 23$ & $\ldots \ldots \ldots 72$ & inge...........53 \\
\hline$\ldots \ldots \ldots \ldots \ldots 23$ & Shrubs .....4 $45-53$ & $\ldots \ldots \ldots \ldots \ldots \ldots 73$ \\
\hline ............ $5^{8}$ & Material 64 & ….........31 \\
\hline ries............85 & ...... & n....... \\
\hline$\ldots \ldots \ldots \ldots \ldots 7_{68}$ & .... & $\ldots \ldots \ldots \ldots$ \\
\hline$\ldots \ldots \cdots \cdots \cdots{ }_{68}^{68}$ & $\ldots \ldots \cdots$ & , . . . . . . \\
\hline$\cdots \cdots \cdots \cdots \cdots, 66_{65}$ & $0,7 \pi$ & le $\ldots \ldots \ldots \ldots \ldots+\ldots$ \\
\hline$\ldots$ F.......54, 65 & ....... & sotis $\ldots \ldots \ldots \ldots \ldots$ \\
\hline ed Evergreen & .086 & $\ldots \ldots \ldots \ldots$ \\
\hline$\ldots \ldots \ldots \ldots .54-58$ & .66 & Tea....... .5 I \\
\hline 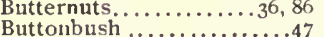 & $\ldots \ldots \ldots \ldots \ldots 7$ I & laple ...... \\
\hline 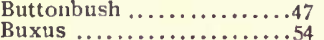 & $\ldots \ldots \ldots \ldots \ldots 7 r$ & Trees ............. 86 \\
\hline$\ldots \ldots \ldots \ldots \ldots \ldots+54$ & $\ldots \ldots \ldots$ & Nyssa.................34 \\
\hline$\ldots \ldots \ldots \ldots \ldots{ }^{68}$ & & .32 \\
\hline hus $\ldots \ldots \cdots \cdots \cdots \cdots b^{53}$ & .50 & . $\ldots \ldots \ldots \ldots$ \\
\hline $1 \mathrm{a} \ldots \ldots \ldots \ldots \ldots$ & $111, \ldots \ldots \ldots$ & $\cdots \cdots \cdots \cdots \cdots \cdots+7$ \\
\hline ana $\ldots \ldots \ldots \ldots \ldots \ldots{ }^{52}$ & .83 & disea ..............73 \\
\hline${ }_{11 u s} \ldots \ldots \ldots \ldots \ldots \ldots \ldots m^{25}$ & .......... & nia $\ldots . . . \ldots \ldots$ \\
\hline$\cdots \cdots \cdots \cdots \cdots \cdots \cdots \cdots \cdots{ }_{69}$ & .71 & $\ldots \ldots \ldots \ldots 34,8 \mathbf{r}$ \\
\hline$\cdots \cdots \cdots \cdots \cdots$ & 35 & $\ldots \ldots 4^{8}$ \\
\hline lea $\ldots \ldots \ldots \ldots \ldots{ }^{24}$ & & \\
\hline$\ldots \ldots \ldots 23,4^{8}, 64,65$ & 77 & $n \ldots \ldots \ldots \ldots$ \\
\hline is $\ldots \ldots \ldots \ldots \ldots$. 5 I & $7-75$ & $e \ldots \ldots . . . .$. \\
\hline$\ldots \ldots \ldots \ldots \ldots \ldots$ & .35 & e $\ldots \ldots \ldots \ldots, 5^{6}, 75$ \\
\hline$\ldots \ldots \ldots \ldots \ldots$ & .71 & is $\ldots \ldots \ldots 34,82$ \\
\hline$\ldots \ldots \ldots \ldots \ldots \ldots 5^{8}$ & & $013 . \ldots \ldots$ \\
\hline$\ldots \ldots \ldots \ldots \ldots 69$ & & lphus ... \\
\hline hus............4 47 & & .73 \\
\hline cus ...........40 & ruce...... & \\
\hline ii...........69 & ub $\ldots . . . .$. & $\ldots \ldots \ldots \ldots \ldots$ \\
\hline hyllum $\ldots \ldots \ldots .23$ & 6,71 & \\
\hline ...........26, 49 & 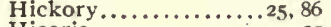 & .42 \\
\hline$\ldots \ldots \ldots \ldots \ldots 82$ & .25 & \\
\hline & .55 & ting a Tree........ \\
\hline & & $\ldots \ldots \ldots \ldots \ldots$ \\
\hline er........74 & rle...... & .74 \\
\hline ork Tre & .25 & $\ldots \ldots \ldots \ldots \ldots \ldots$ \\
\hline & estnut ........ & \\
\hline & $\ldots .49$ & . $\ldots \ldots \ldots \ldots \ldots$ \\
\hline aterial.....66 & & .74 \\
\hline & rant .... & .74 \\
\hline & ADC & \\
\hline & Ir & $.5 \mathrm{r}, 64,65$ \\
\hline & & $\ldots 24,34$ \\
\hline & & $\ldots \ldots 60$ \\
\hline & la Tree & le Fringe.. \\
\hline & $\mathrm{J} u$ & rethrum..... \\
\hline$\ldots \ldots 24,4^{8}$ & Live-forever. & Pyrus... \\
\hline & Maple......... & \\
\hline & & \\
\hline & & poerres. \\
\hline Cypress............... & & \\
\hline
\end{tabular}

Red Cedar..........38, 43, 65, 66 dendro13.....46, 56, 58 Rhodotypos.............5 Rhus ............. 52, 53 Rose Acacia.

Roses, Climbing. ........4 Rose of Sharon ........... Roses $\ldots \ldots \ldots \ldots .46$ Rudbeckia................ Salix..................... Salvia.................

Sambucus................ Sallguinaria..............74

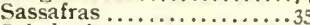
Sciadopitys............... 43 Sedum...

Siherian Pea ree ......... $5^{2}$

Silphium...............75

Silver Beli, or Snowdrop

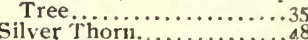

Silver Thorm.............48

Smoke Tree .............

Sophora..................35

Solonon's Seal............74

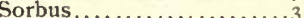

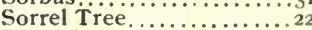

Sparish Bayonet............75

Speedwell..............7

Spiderwort ..............

Spruce $\ldots \ldots \ldots \ldots \ldots \ldots, 43,65$

Stachys ...............43,

Stokes' Aster .................

Stokesia.....

Strawberries.

Styrax

Sweet Gum

Sweet Pepper-hushi ..........

Sweet-scented Shrut ......53

Symphoricarpus ........49

Syringa $\ldots \ldots \ldots \ldots . .50,53$

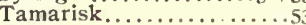

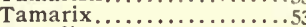

Taxodium ................ 4

Taxus ..............

Thernopsis............75

Thorn ................ $35,5^{8}$

Thuya .................

Thymus $\ldots \ldots \ldots \ldots \ldots \ldots \ldots \ldots+75$

Tilia

Tradescantia ............ 75

Tree-Moving.......18, 19, 20

Tree Peony...............73

Trollius

Trumpet $\mathrm{V}$ ine ..............6

Trumpet Creeper...........60

Tsuga................. 4

Tubs.......................6

Tulip Tree........................

Tulip Tree $\ldots \ldots \ldots \ldots \ldots \ldots . . . \ldots \ldots$

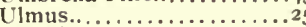

Valerian................ 75

Valeriana...............75

Veronica.............

Viburnum..................

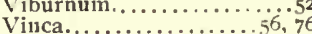

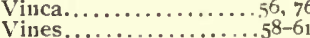

Virginia Creeper ........6r

IValnut..................36

Wax Myrtle.............47

Weigela..................53

Willow $\ldots . . . . . .35,53$

Wista ria ................

Witch-hazel ............. 53

Xanthor rhiza ...............5

Yellow Root ...............5.

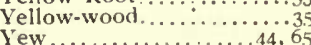

Yew .................... 


